\title{
Boros Péter
}

\author{
A partnerkockázat árazása - A hitelértékelési \\ kiigazítás elemzése
}


Befektetések és Vállalati Pénzügy Tanszék

Témavezetô: Medvegyev Péter CSc

Copyright (C)Boros Péter 
Budapesti Corvinus Egyetem

Általános és Kvantitatív Közgazdaságtan Doktori Iskola

A partnerkockázat árazása - A hitelértékelési kiigazítás elemzése

Doktori Értekezés

Boros Péter

Budapest, 2019 



\section{Tartalomjegyzék}

1. Bevezetés 1

1.1. Alapfogalmak . . . . . . . . . . . . . . . . . 6

1.2. Partnerkockázat alapok . . . . . . . . . . . . . . . . . . 9 9

1.2.1. A kitettség modellezése . . . . . . . . . . . . . . . 13

1.2.2. A csődesemény modellezése . . . . . . . . . . . . . 20

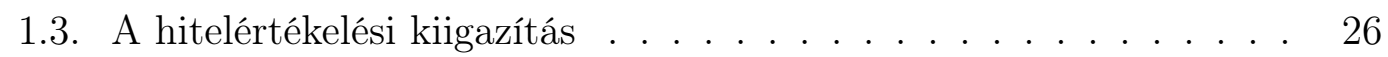

1.3.1. A CVA értelmezése és alternatív megközelítései . . . . . . 35

1.3.2. Szabályozói reformok . . . . . . . . . . . . . . . . . 41

1.3.3. A hitelértékelési kiigazítás relevanciája . . . . . . . . . 45

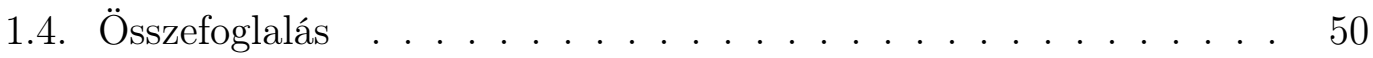

2. A kitettség profil és a hitelértékelési kiigazítás meghatározásának numerikus módszerei $\quad 51$

2.1. A kitettség profilok becslése többszintú Monte Carlo módszerrel . 52

2.1.1. Alapfogalmak . . . . . . . . . . . . . . . . 53

2.1.2. Többszintú Monte Carlo a várható pozitív kitettség profil

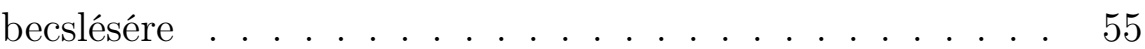

2.1.3. Numerikus eredmények . . . . . . . . . . . . . . . . . 60

2.2. A hitelértékelési kiigazítás számítása csökkentett memória igényú

Legkisebb Négyzetes Monte Carlo módszerrel … . . . . . . . 68

2.2.1. Az LSMC módszer és a hitelértékelési kiigazítás . . . . . . 70

2.2.2. Korai lehívási opció nélküli termékek … . . . . . 75

2.2.3. Termékek korai lehívhatósággal … . . . . . . . 85

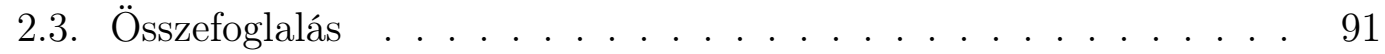

3. A hitelminôsítôi bejelentések fertôzô hatásai és a hitelértékelési

kiigazítás 93

3.1. A hitelminősítői bejelentések és a csődesemények hatása . . . . . 95

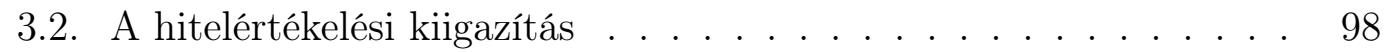

3.3. A modell . . . . . . . . . . . . . . . . . . . . . . . . . 101

3.4. Numerikus példa . . . . . . . . . . . . . . . . . . . 106 
3.5. Összefoglalás . . . . . . . . . . . . . . . . . . . . . . . . 114

4. A hitelértékelési kiigazítás tôketartalékolásának új szabályozása 116

4.1. Tóketartalékolás az alap CVA módszer szerint . . . . . . . . . . 119

4.2. Az alap formula modellkerete . . . . . . . . . . . . . . . 123

4.3. $\quad$ Numerikus eredmények . . . . . . . . . . . . . . . . . . . 128

4.4. A végsố szabályozói keret . . . . . . . . . . . . . . . . . . 138

4.5. Összefoglalás . . . . . . . . . . . . . . . . . 139

$\begin{array}{ll}\text { 5. Összefoglalás } & 141\end{array}$ 


\section{Ábrák jegyzéke}

1.1. A globális OTC piac kockázati típusonként bontva (Névérték) . . 7

1.2. A globális OTC piac kockázati típusonként bontva (Bruttó piaci érték) . . . . . . . . . . . . . . . . 7

1.3. A klíringelt pozíciók aránya (Névérték) . . . . . . . . . . . . 8

2.1. Elméleti profil . . . . . . . . . . . . . . . . . . . 63

2.2. Standard hiba különböző szimulációs szám mellett . . . . . . . . . 64

2.3. Az elméleti értéktôl vett átlagos négyzetes eltérés különbözô szimulációs szám mellett. . . . . . . . . . . . . . . . . . . . 65

2.4. Az elméleti értéktôl vett átlagos négyzetes eltérés alternatív kiinduló szimuláció számok mellett. . . . . . . . . . . . . . . 66

2.5. Átlagos futási idô . . . . . . . . . . . . . . . . . . 67

2.6. Csôdvalószínúségek a felhasznált számpéldában. $\left[\mathbb{Q}\left(t_{i-1}<\tau \leq t_{i}\right)\right] \quad 82$

2.7. Kamatláb csereügylet várható kitettség profilja késleltetett fedezettel 83

2.8. Memóriaszükséglet a szimuláció során felhasznált utak függvényében 85

2.9. Futási idố a szimuláció során felhasznált utak függvényében. . . . 85

2.10. Felmondható kamatláb csereügylet várható kitettség profilja késleltetett fedezettel . . . . . . . . . . . . . . . . . . 89

2.11. Memóriaszükséglet a szimuláció során felhasznált utak függvényében egy felmondható kamatláb csereügylet esetén . . . . . . . . . 90

2.12. Futási idő a szimuláció során felhasznált utak függvényében egy felmondható kamatláb csereügylet esetén . . . . . . . . . . . . . . 91

3.1. A változó letéttel kiegészített CVA számítása - Az összes lehetséges eset. . . . . . . . . . . . . . . . . . . . . . 99

3.2. Túlélési valószínúségek különbözô kiinduló hitelminôsítés és iparági összetétel mellett . . . . . . . . . . . . . . . . . . . . . . . 111

4.1. A korreláció hatása egy átlagos portfólió esetén . . . . . . . . . . 129

4.2. A korreláció hatása jó minôségú portfólió esetén . . . . . . . . . . . 130

4.3. A korreláció hatása rossz minôségú portfólió esetén . . . . . . . . . 130

4.4. A korreláció hatása egy átlagos portfólió esetén - QIS súlyokkal • 133 
4.5. A korreláció hatása jó minőségú portfólió esetén - QIS súlyokkal . 133 4.6. A korreláció hatása rossz minôségû portfólió esetén - QIS súlyokkal 134 4.7. IG Portfólió . . . . . . . . . . . . . . . . . . . . . . . . . . . . . 135

4.8. NIG Portfólió . . . . . . . . . . . . . . . . . . . . . . . . . . . . 136

4.9. IG Portfolió - 1. opció (balra) és 2. opció (jobbra) . . . . . . . . . 137

4.10. NIG Portfolió - 1. opció (balra) és 2. opció (jobbra) . . . . . . . . 138 


\section{Táblázatok jegyzéke}

1.1. Nettósítás példa: Különböző partnerekkel kötött pozíciók aktuális piaci értéke és a partnerek azonnali csődje miatti veszteség . . . . 11

2.1. Pénzáramok B szemszögéből a derivatív csőd miatti zárásakor . . 54

2.2. A numerikus példában használt paraméterek és a fair csereügylet kamat ........................... 62

2.3. A numerikus példában használt paraméterek . . . . . . . . . . . . 82

2.4. A hitelértékelési kiigazítás 100 futtatás alapján becsült értékei . . 84

2.5. A felmondható kamatláb csereügylet hitelértékelési kiigazításának 100 futtatás alapján becsült értékei . . . . . . . . . . . . . . . 90

3.1. Kiinduló egy éves átmenetmátrix . . . . . . . . . . . . . 107

3.2. Kockázatsemleges egy éves átmenetmátrix . . . . . . . . . . . . . 109

3.3. A modell paramétereinek becsült értékei. . . . . . . . . . . . . . . 109

3.4. A fennmaradó négy vállalat hitelminôsítése csoportonként. . . . . 110

3.5. Az egyoldalú hitelértékelési kiigazítás értéke különböző feltételek mellett . . . . . . . . . . . . . . . . . . . . . . 112

3.6. Kétoldalú hitelértékelési kiigazítás - 1. Csoport vs 3. Csoport . . . 113

3.7. Kétoldalú hitelértékelési kiigazítás - 2. Csoport vs 1. Csoport . . . 113

4.1. Korrelációs paraméterek . . . . . . . . . . . . . . . . . . . 122

4.2. Kockázati súlyok . . . . . . . . . . . . . . . . . . . . . . . . . 128

4.3. Kockázati súlyok az iparági felmérés keretében . . . . . . . . . . . 132 


\section{Jelölések jegyzéke}

Az alábbi lista a legfontosabb jelöléseket és rövid leírásukat tartalmazza:

$R E C, R E C_{i} \quad$ A partner nemteljesítésekori megtérülési ráta, kiegészítve alsó indexben a partner megjelölésével, ahol ez nem egyértelmú.

$R E C_{i}^{\prime} \quad$ A fedezeti számlára vonatkozó nemteljesítéskori megtérülési ráta kiegészítve alsó indexben a partner megjelölésével.

$L G D, L G D_{i} \quad$ A partner nemteljesítésekori veszteség ráta, kiegészítve alsó indexben a partner megjelölésével, ahol ez nem egyértelmú.

$D(t, T) \quad$ A t és T közötti diszkontfaktor.

$\Pi(t, T) \quad$ A t és $\mathrm{T}$ idôpontok közötti partnerkockázat mentes pénzáramok t időpontra diszkontált összege.

$\overline{\Pi(t, T)} \quad$ A t és T idôpontok közötti partnerkockázattal kiigazított pénzáramok t idôpontra diszkontált összege.

$\Pi^{x}\left(t_{3},\left(t_{1}, t_{2}\right]\right) \quad$ A $t_{1}$ és $t_{2}$ között esedékes, de nem kifizetett pénzáramok $t_{3}$-ban vett értéke, ahol $x$ mutatja a pénzáramok irányát.

$V_{t}, V_{t}^{i} \quad$ A partnerkockázat mentes derivatív értéke t idôpontban kiegészítve felsô indexben annak a partnernek a megjelölésével, amelyik szemszögéból végezzük az árazást, ha ezt máshogy nem specifikáljuk.

$C_{t} \quad$ A letét t idôpontra előírt egyenlege.

$K_{t} \quad$ A letét t idôpontban rendelkezésre álló egyenlege.

$E_{t} \quad$ A t időpontban fennálló kitettség.

$\zeta, \delta \quad$ A margin periódus hossza időben $(\zeta)$ és az idő felosztáshoz használt indexeken $\left(t_{j+\delta}-t_{j}=\zeta\right)$.

$C E \quad$ Az azonnali kitettség.

$P F E^{\alpha}(t) \quad$ A potenciális jövőbeli kitettség.

$E E(t) \quad$ A t időpontbeli várható kitettség értéke.

$E E^{*}(t) \quad$ A t idôpontbeli várható diszkontált kitettség értéke.

EPE Átlagos pozitív kitettség.

$T \quad$ A derivatíva lejáratának ideje.

$1_{(a \in \mathcal{A})} \quad \mathrm{Az}$ indikátor folyamat, amely értéke 1 , ha $a \in \mathcal{A}$ és 0 egyébként. 
$\tau, \tau_{i} \quad$ A csődidőpont, kiegészítve alsó indexben a nemteljesítő partner megjelölésével.

$\mathcal{E}, \mathcal{E}_{i, j} \quad$ Egységnyi várható értékú exponenciális valószínúségi változó és független sorozatuk.

$\lambda(t) \quad$ A csődintenzitás folyamat értéke $t$ időpontban.

$\Lambda(t) \quad$ A kumulált intenzitás folyamat értéke $t$ idópontban.

$C V A_{t}, C V A_{t}^{i} \quad \mathrm{Az}$ egyoldalú hitelértékelési kiigazítás értéke t idôpontban, kiegészítve a felsố indexben annak a partnernek a megjelölésével, amelynek a szemszögéból végezzük a számítást. A $t=0$ esetben az alsó indexet elhagyjuk.

$D V A_{t}, D V A_{t}^{i} \quad$ Az egyoldalú kötelezettségértékelési kiigazítás értéke t időpontban, kiegészítve a felsó indexben annak a partnernek a megjelölésével, amelynek a szemszögéból végezzük a számítást. A $t=0$ esetben az alsó indexet elhagyjuk.

$B C V A_{t}^{i} \quad$ A kétoldalú hitelértékelési kiigazítás értéke t idôpontban, kiegészítve a felsố indexben annak a partnernek a megjelölésével, amelynek a szemszögéból végezzük a számítást. A $t=0$ esetben az alsó indexet elhagyjuk.

$b C V A_{t}^{i}, b D V A_{t}^{i}$ A BCVA hitelértékelési és kötelezettségértékelési kiigazítás komponensei t időpontban, kiegészítve a felső indexben annak a partnernek a megjelölésével, amelynek a szemszögéból végezzük a számítást. A $t=0$ esetben az alsó indexet elhagyjuk. 


\section{Köszönetnyilvánítás}

Egy hosszú út vezetett el a disszertáció megírásához, azonban ezen az úton soha nem voltam egyedül. Szeretném megköszönni Medvegyev Péternek, hogy elvállalta a kutatásom vezetését valamint, hogy mindenkor támogatta a munkámat. Emellett nem tudok elég hálás lenni családomnak. Édesanyám és Édesapám az elmúlt években - ugyanúgy, mint egész életem során - végig bíztattak és támogattak. Rengeteget köszönhetek nekik. Külön köszönet illeti meg a feleségemet, Enikôt, amiért mindig mellettem állt. Remek ötletein és építő jellegú visszajelzésein túl, egész idő alatt segített átlendülni a nehéz helyzeteken, miközben türelemmel és megértéssel kezelte a munka miatti lemondásokat. Nélküle nem készülhetett volna el a dolgozat. 


\section{1. fejezet}

\section{Bevezetés}

A dolgozat a partnerkockázat kezelésének egyik módszerével, a partnerkockázat árazásával foglalkozik. Partnerkockázat alatt az OTC piacokon megkötött derivatív szerződések élettartama során, a partnerek lehetséges nemteljesítéséból eredô veszteség kockázatát értem!1 Ez a pénzügyi kockázattípus a hitelkockázat családjához tartozik, és igazán csak a 2008-as gazdasági válság óta került a figyelem középpontjába. A partnerkockázat árazása a kockázat számszerúsítésének egy módját jelenti, amelyet hitelértékelési kiigazításnak neveznek. A dolgozat során a hitelértékelési kiigazításra az angol „Credit Valuation Adjustment” elnevezés alapján CVA rövidítéssel is fogok hivatkozni. A CVA egy árkiigazítási tényező, amely egy nemteljesítési kockázattól mentes származtatott termék árát olyan irányba módosítja, hogy az tükrözze az aktuális partnerek nemteljesítési kockázatából adódó veszteségeket. Az így kapott új árat kockázattal kiigazított árnak nevezik.

A hitelértékelési kiigazítás meghatározása egy komplex számítási probléma megoldása, amely kvantitatív módszerekre támaszkodik. A dolgozatban ezért olyan számszerúsített modellekkel foglalkozom, amelyek mind elméleti, mind gyakorlati szempontból különös relevanciával bírnak. A modellek a közgazdaságtan témáján belül a matematikai pénzügyek területére sorolhatóak.

A partnerkockázat az OTC piacok kialakulása óta létező fogalom, azonban a 2008-as gazdasági világválságig egy kevésbé fontos területnek számított. A válság előtt kialakult piaci gyakorlat szerint a partnerkockázat árát elhanyagolhatónak tekintették (Pykhtin és Rosen, 2010), avagy az csupán a nagy intézmények kiváltságának számított, amikor kisebb szereplőkkel szerződtek (Skoglund et al., 2013). Cesari et al. (2009) szerint azonban a válság rámutatott, hogy minden derivatív szerződéssel rendelkező félnek alapvető fontosságú a partnerkockázat mérése, az annak megfelelő tőke tartalékolása, és a partnerkockázat fedezése. Így a part-

${ }^{1}$ A partnerkockázat definíciója megadható több, általánosabb formában is, hiszen többek között az értékpapír finanszírozási ügyletek esetében is felmerül ez a kockázat típus. A dolgozatban elsósorban az OTC piacokon megkötött derivatívákkal foglalkozom, ezért is használom a fenti definíciót. 
nerkockázat modelljei is fejlődésnek indultak. Ezeket a modelleket általánosan Bielecki és Rutkowski (2013) leírásával jellemezhetjük: a hitelkockázat kvantitatív modelljeinek általános célja, hogy lehetôséget teremtsenek olyan szerződések árazására és fedezésére, amelyek hitelkockázatnak vannak kitéve.

A hitelértékelési kiigazítás témája több részre bontható. Elsóként megkülönböztetjük a számviteli és a szabályozói CVA mennyiségeket. A számviteli CVA alatt a már fentebb leírt árkiigazítási tényezôt értem. A szabályozói CVA a számviteli CVA egyik mellékterméke, amely a hitelértékelési kiigazítás mozgásából adódó veszteségek miatti tóketartalékolást jelenti. A dolgozat során a számviteli CVA helyett egyszerűen a hitelértékelési kiigazítás vagy a CVA elnevezést fogom használni, míg a megkülönböztetés miatt megtartom a szabályozói CVA elnevezést.

A hitelértékelési kiigazítás komplexitása az azt befolyásoló tényezôk számszerúsítésének nehézségeiból adódik. A probléma árazási jellege miatt egy számba kell tömöríteni olyan faktorok összességét, mint a partnerek nemteljesítésének idôpontja, a fennálló tartozások mértéke vagy éppen a nemteljesítéskori veszteség nagysága. Ezen paraméterek meghatározása és azok összekapcsolása adják a hitelértékelési kiigazítás témájának további bontásait. Így a CVA modellezésekor többek között megkülönböztetünk csődesemény vagy éppen kitettség modelleket. A részletes leírást a következô fejezetekre hagyva, az Olvasó már érezheti, hogy a hitelértékelési kiigazítás még a legegyszerúbb termékhez is egy bonyolult, számításigényes feladatot rendel.

A dolgozat elsődleges célja, hogy egy széleskörü leírást adjon a partnerkockázat árazásáról. Ezenfelül azonban más célok is kitúzésre kerültek: Az átfogó leírás megtartása mellett, szeretném kiemelni és részletesen ismertetni a téma néhány fontos alterületét. Továbbá a már rendelkezésre álló eszköztárat kívánom javítani és bővíteni új módszerek építésével, valamint létező eljárások kiegészítésével. Mindezek mellett célom, hogy rámutassak a terület hiányosságaira és esetlegesen ezeket új módszertan fejlesztésével felmérjem és feloldjam. Mégis a dolgozat fố célja, hogy egy átfogó képet adjon a hitelértékelési kiigazításról. A terjedelmi korlátok miatt természetesen nem tudom a téma minden pontját érinteni, de a széleskörú leírás megtartása érdekében a dolgozat fejezeteiben a fentebbi kategorizálást követem. Ennélfogva a dolgozat 2 , és 3 , fejezetében a (számviteli) hitelértékelési kiigazítás különbözô elemeivel foglalkozom és a 4 fejezetben térek rá a szabályozói CVA részletes elemzésére. A jelen 1. fejezetet célja a hitelértékelési kiigazítás alapfogalmainak és a téma szakirodalmának ismertetése. A dolgozatot egy összefoglalással zárom az 5. fejezetben. Ez a szerkezet lehetôséget ad arra, hogy a megfogalmazott céljaimat egy strukturált formában teljesítsem. Továbbá a fejezetek fenti tagolásával rámutatok a CVA területének alternatív 
dimenziók szerinti felosztására is, hiszen többek között felhívom a figyelmet az elmélet kihívásaira, megvizsgálom a becslési eljárások bizonyos technikai kérdéseit, megkérdôjelezem a számítást befolyásoló faktorok körét, valamint a szabályozók szemszögéból is elemzem a témát. Mindezek mellett, a fenti strukturálás egy alulról felfelé történő építkezést követ: a 2 és a 3 fejezetben a hitelértékelési kiigazítást annak komponensein keresztül ismerjük meg. Világos azonban, hogy ezek magát a hitelértékelési kiigazítást is dinamikussá teszik, amely dinamikát egy speciális szabályozói szemüvegen keresztül majd a 4 . fejezetben vizsgálom meg.

Az1. fejezet következô részeiben szakaszosan építem fel a hitelértékelési kiigazítás definícióját. Ehhez sorra veszem a partnerkockázat alapfogalmait, a kitettség modellezésének elméleti alapjait és a csődmodellezés leggyakoribb eszköztárát. Ezt követően ismertetem a hitelértékelési kiigazítást és annak alternatív típusait, valamint azok számszerúsítésének módszereit. A technikai bemutatás után megvizsgálom a CVA értelmezését. A téma relevanciájának indoklásához áttekintem az elmúlt évtized legfontosabb szabályozói változtatásait, amelyek a partnerkockázat területét érintették. A fejezetben minden bemutatott terület mellett kitérek azok szakirodalmának az ismertetésére. Az 1. fejezetnek több célja is van. Elsődlegesen a következő fejezetekben bemutatott eredmények megértését segíti elô az alapfogalmak és a jelölések bemutatásán keresztül. A dolgozatot úgy építettem fel, hogy az egyes fejezetek egymástól függetlenül is olvashatóak legyenek. Így minden fejezetben kitérek a legfontosabb fogalmak és jelölések rövid bemutatására. Mégis - a felépítésének jellege miatt - az 1 rész látja el a fejezeteket összekötő tanulmány szerepkörét, amely így egy átfogó képet ad a hitelértékelési kiigazításról azáltal, hogy összekapcsolja egyes altémáit. Emiatt az alaposabb megértés és az egyes témák közötti kapcsolat elsajátítása érdekében fontos az 1. fejezet feldolgozása is. Mindezek mellett a hivatkozott szakirodalom miatt a fejezet egy átfogó szakirodalmi útmutatóként is szolgál. Ez lehetôvé teheti további kutatások elindítását, vagy a kevésbé érintett témák jobb megismerését.

A fejezet igazi újdonsága azonban abban rejlik, hogy a téma bemutatása magyar nyelven történik. A hitelértékelési kiigazítás kutatásának magyar közössége kicsi. A következốkben leírt bevezetés segíthet a téma kutatásának népszerúsítésében, illetve hasznos anyag lehet annak tanítása során.

A 2. fejezetben a partnerkockázat fontos mennyiségeinek számításával foglalkozom. Ebben a részben a kitettség meghatározására helyezem a hangsúlyt. Így olyan numerikus módszereket vezetek be, amelyek a kitettség profil vagy éppen a hitelértékelési kiigazítás meghatározására használhatóak. A módszerek újítása, hogy azok egyrészt bővítik valamint fejlesztik a rendelkezésre álló eszköztárat, másrészt kisebb számítási kapacitást követelnek meg. Amint látni fogjuk a hitelér- 
tékelési kiigazítás meghatározása jelentôs számítási erőforrásokat igényel. Emiatt a szakirodalom egyik népszerú területe a hitelértékelési kiigazítást meghatározó módszerek hatékonyságának növelése.

A fejezetet két részre osztom. Az elsô részben a kitettség profilok számítására vezetek be egy új módszert, aminek alapjait a többszintú Monte Carlo technikára építem. A módszert egy algoritmus formájában adom meg. Az eljárás lényege, hogy a profil újabb pontjainak becslésekor felhasználjuk a korábban már meghatározott pontokat azért, hogy becslésünk hibáját és ezáltal az újabb pontokhoz felhasznált utak számát csökkenthessük. Miközben az eljárás végighalad a kitettség profil egyes pontjain, folyamatosan csökkenti a szimulációs utak számát, amely miatt összességében jelentősen kevesebb pont szimulálására van szükség. A hagyományos Monte Carlo módszerrel szemben így jelentôs teljesítmény javulás érhető el, ami a futási idő csökkenésében lesz mérhető. A fejezetben felhívom a figyelmet a hiba felhalmozódásának problémájára is, de numerikus példákon keresztül rámutatok, hogy a hatékonyságjavítás így is jelentôs.

A fejezet második részében olyan komplex termékek hitelértékelési kiigazításának számításával foglalkozom, amelyek esetében nem létezik analitikus árazó formula. Elsóként a szakirodalomban népszerú legkisebb négyzetes Monte Carlo módszer fejlesztésével foglalkozok, ahol is beépítem a fedezet késését a modellbe. Ezután rámutatok, hogy az eredeti eljárás magas memóriaigénye a javított változatban még tovább fokozódik. Ennek mérséklésére bevezetem az eljárás egy alternatív változatát, amellyel csökkenthetô az eredeti módszer jelentôsre növekvô memóriaigénye és megszüntethetôek az amiatt generált problémák. A módszer új változatát két algoritmuson keresztül írom le, külön kezelve a korai lehívási opcióval rendelkezô és az anélküli termékeket. Mindkét esetben numerikus példákon mutatom meg, hogy az új eljárás jól teljesít, miközben memória felhasználása csökken.

A 3. fejezetben a hitelértékelési kiigazítás másik fô inputjára, a csődvalószínúségre fókuszálok. A hitelértékelési kiigazítás modellezésénél már régóta vizsgált téma a csődesemények közötti korreláció hatása. Az ilyen korrelációs modellek egyik altípusa az úgynevezett fertôző csődesemények modellje, amelyek a csődesemények után fellépő piaci fertôzést számszerúsítik. A szakirodalom empirikus eredményei azonban rámutattak, hogy a csődesemények mellett a hitelminősítői intézmények bejelentései is járhatnak fertôző hatásokkal. Ezen hatások a csődvalószínûségek változásán keresztül érinthetik a hitelértékelési kiigazítás értékét is, amit a téma szakirodalma jellemzően figyelmen kívül hagy. Így releváns feltenni azt a kérdést, hogy hogyan is befolyásolják a hitelbesorolásokban bekövetkezô változások fertőző hatásai a hitelértékelési kiigazítást. A kérdés megválaszolását a probléma részletes megértésével kell kezdeni, így először ismertetem a szakiro- 
dalom empirikus eredményeit. Ezután megfogalmazok egy modellt, amellyel az empirikus megfigyelések előállíthatóak és elemezhetôek. A modellem gerincét a feltételes intenzitás folyamat képezi, amelyhez a feltétel nélküli intenzitás folyamat skálázásával jutok el. A skálázáshoz figyelembe veszem a piaci szereplők hitelminősítéseiben bekövetkező változásokat, és azokat az empirikus szakirodalom megfigyelésein keresztül építem be a skálázó faktorba. Ennél a pontnál azonban a szakirodalomban körkörös csődesemények néven ismert problémába ütközöm. A fentebb említett fertőző csődesemények modellje a csődesemények és az azokat generáló intenzitás folyamatok vállalatokon átívelő függôsége miatt jelentős implementációs kihívásokat állít. A problémát egy új megoldási algoritmussal oldom fel, amelyet lépésrôl lépésre felépítve adok meg. A modellt és az algoritmust numerikus példákon keresztül tesztelem. A fejezetben elvégzett numerikus eredményeim azt mutatják, hogy a fertôzés hatása nem elhanyagolható a kétoldalú hitelértékelési kiigazítás számításakor. Annak figyelembevétele az iparági összetételtôl és a kiinduló hitelbesorolástól függhet, így az általam épített eszköztár fontos feladatot kaphat.

A 4. fejezetben a szabályozói CVA témájával foglalkozom. A CVA mozgásából adódó veszteségek miatti tóketartalékolás mára már bevett gyakorlatnak számít. A tóketartalékolás szabályai azonban változáson mennek keresztül. Ebben a fejezetben az új szabályozás egyik módszerét az úgynevezett alap CVA módszert vizsgálom meg. Az új szabályozást jelentôs bizonytalanság előzte meg, amely a piaci szereplóket negatívan érintette. A szabályozók a módszer újratervezésekor több lehetséges opciót is publikáltak, amelyek a tóketartalék jelentôs emelkedését okozták. A fejezetben végig követem az alap CVA módszer történetét és fejlődését az elsô javaslattól, az iparági felmérések során publikált változatokon át, egészen a végleges szabályozói alakig. A fejezet célja a szabályozás analitikus szemszögből történő ismertetése és elemzése. Bemutatom a szabályozói formulák mögött meghúzódó modellkeretet, a felhasznált feltételezéseket valamint a szabályozók standardizálási és konzervatív közelítéseit. A fejezet elsố eredménye, hogy levezetek egy analitikus formulát, amely a szabályozói modell valós tókeszükségletét írja le. Később ezt a formulát a szabályozói alakhoz hasonlítom, hogy megvizsgáljam, hogy melyek azok a területek, amelyek miatt a szabályozói és a számviteli CVA továbbra is eltér, valamint hogy azok milyen következménnyel járnak.

A dolgozatot egy összefoglalással zárom, amelyben felidézem a főbb eredményeket és kitérek azokra az irányokra, amelyek vizsgálatával és elemzésével eredményeim tovább fejleszthetők.

Mielőtt elkezdem az alapfogalmat ismertetését, röviden kitérek a disszertáció szerkezetére. A dolgozat felépítésének kialakításakor igyekeztem egy olyan struktúrát követni, amely megkönnyíti az olvasást. Ennek érdekében a fejezetek elején 
röviden felidézem azokat a legfontosabb alapfogalmakat és jelöléseiket, amelyeket az adott részben felhasználok. Ez lehetôvé teszi, hogy az Olvasó a fejezeten belül megtalálja a legfontosabb egyenleteket és így nincs feltétlen szükség a fejezetek közötti ugrásra egy-egy visszahivatkozott formula megtalálásához. Természetesen, az 1. fejezet az alapfogalmak részletesebb leírását adja, így az ahhoz történô visszalapozás is segíthet, de a dolgozat minden nagyobb egysége önmagában is olvasható. Mindezek mellett az átláthatóság javítása érdekében a dolgozat elején található jelölésjegyzékben gyưjtöttem össze a legfontosabb jelöléseket és a hozzájuk tartozó magyarázatot.

\subsection{Alapfogalmak}

A dolgozat során számos esetben fel fogok használni a piaci gyakorlatban ismert fogalmakat, amelyeket az elmélet valamint az eredményeim ismertetésekor már nem fogok külön megmagyarázni. Ezen alapfogalmak többsége feltételezhetôen ismerôs a pénzügyek területén valamelyest járatos, de a partnerkockázat-kezelés alapjaival még csak most ismerkedő Olvasónak is. A disszertáció bevezetô részének teljessége miatt azonban mégis úgy gondolom, hogy némely fogalom minimális ismertetése szükséges lehet. Emiatt ezt a szándékosan tömör alfejezetet ezek bemutatásának szentelem.

A partnerkockázat bevezetésben adott definíciójában leszúkítettem a vizsgálat tárgyát az OTC piacra. Az OTC rövidítés az „Over-The-Counter” angol elnevezésból származik. Az OTC piac egy decentralizált, tôzsdén kívüli piac, ahol a felek közvetlenül egymással kereskednek pénzügyi termékeket. Az OTC piac méretének a meghatározására a Nemzetközi Fizetések Bankja (BIS)22 által publikált statisztikákat ${ }^{3}$ használhatjuk. A Nemzetközi Fizetések Bankja hat havonta gyưjt adatokat a nagyobb derivatív kereskedóktől (derivative dealer) és három évente a kisebbektől. Az 1.1-1.3, ábrákon szemléltetett eredmények ezen adatok kombinálásából nyert statisztikákat mutatják. Az 1.1. ábra a kint lévô derivatív állomány névértékét mutatja kockázati kategóriák szerinti bontásban. A teljes derivatív állomány névértéke a 2008-as gazdasági válságig óriási ütemben növekedett, majd 2013-ban tetőzött, amit egy jelentôs csökkenés követett. Az utóbbi években mért érték kisebb kilengésekkel a 2018 év végi 544 billió dollár szint körül mozgott.

${ }^{2}$ A BIS rövidítés az angol „Bank for International Settlements” elnevezésből származik.

${ }^{3}$ A 2018 májusában publikált felmérés elérhetô az alábbi linken: https://www.bis.org/publ/ otc_hy1805.pdf 
1.1. ábra. A globális OTC piac kockázati típusonként bontva (Névérték)

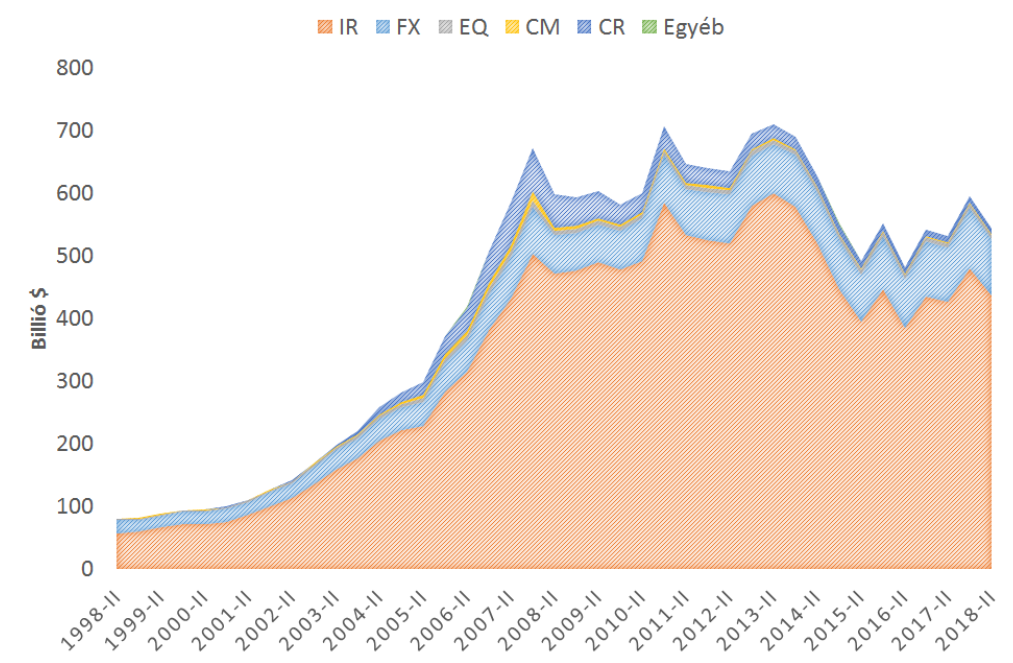

A fô kockázati típusokat a nemzetközi irodalomban használt rövidítésekkel jelöltem. Ennek megfelelően „IR” a kamatláb derivatívákat, „FX” a deviza termékeket, „EQ” a részvény alapú derivatívákat, „CM” a fizikai áruhoz kapcsolódó származtatott termékeket és végül „CR” a hitel derivatívákat jelenti.

A névérték helyett egy másik mértéket, a bruttó piaci értéket is megvizsgálhatjuk, hiszen az közelebb áll a partnerkockázat mérése során használt kitettség fogalomhoz. A bruttó piaci érték 2008 negyedik negyedévekor érte el maximumát és azóta csökkenő trendet mutat. 2018 végére már 10 billió dollár alá csökkent, ami kisebb, mint a 9 évvel korábbi csúcs harmada.

1.2. ábra. A globális OTC piac kockázati típusonként bontva (Bruttó piaci érték)

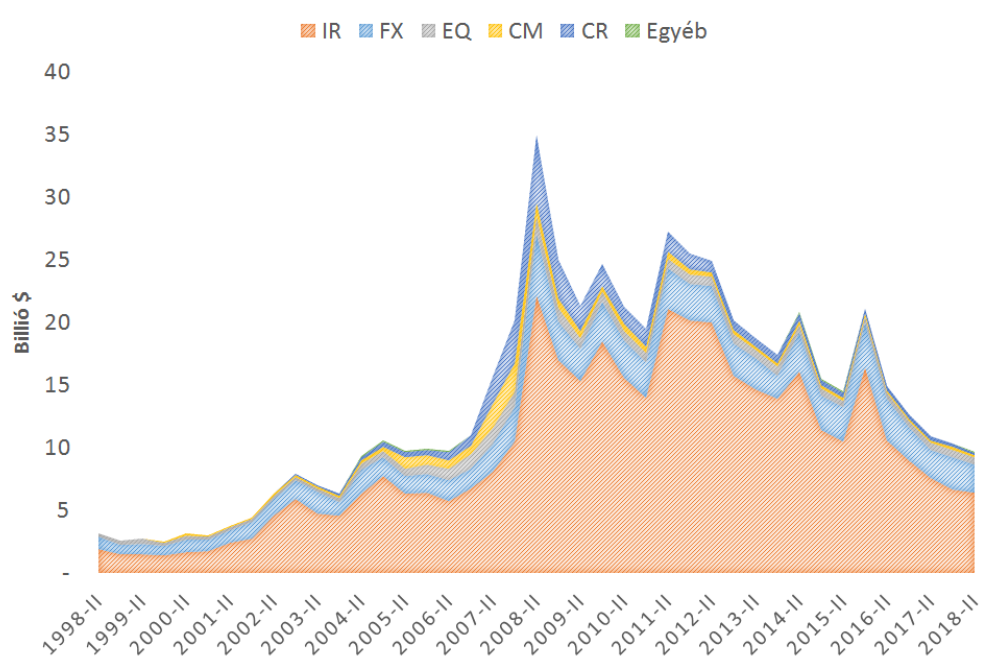

A fő kockázati típusokat a nemzetközi irodalomban használt rövidítésekkel jelöltem. Ennek megfelelóen „IR” a kamatláb derivatívákat, „FX” a deviza termékeket, „EQ” a részvény alapú derivatívákat, „CM” a fizikai áruhoz kapcsolódó származtatott termékeket és végül „CR” a hitel derivatívákat jelenti.

A BIS által kiadott statisztikákban azonban a klíringházon keresztül megkö- 
tött származtatott termékek is szerepelnek. A klíringház a derivatív szerződést megkötő két fél között álló pénzügyi intézmény. A klíringház célja, hogy átvállalja a felek partnerkockázatát, miközben a derivatív mindkét oldalán belépve párosított pozíciókat tart, amik az esetek többségében nem hordoznak piaci kockázatot. Ezek a termékek nem képezik a dolgozat tárgyát, így érdemes azokat különválasztani. Mivel a Nemzetközi Fizetések Bankja csak 2016 júniusa óta publikálja külön a klíringelt derivatívák állományát, így az 1.3. ábrán akkortól szerepeltetem azok arányát a teljes állományhoz képest. Meg kell jegyezni, hogy az adatok a BIS adatgyứjtési folyamata miatt nem pontosak. A kereskedôk közötti derivatív szerzôdések névértéke ugyanis duplán kerül felszámításra, ami a tényleges klíring arány felülbecslését eredményezi ${ }^{4}$ Mégis levonhatjuk azt a következtetést, hogy az elmúlt években a klíringházon keresztül kötött derivatívák aránya növekedett, és hogy a nem klíringelt származtatott termékek továbbra is jelentôs részt képeznek. A klíringelt termékek növekedése mögött elsôsorban szabályozói nyomás áll, amelyre még hamarosan visszatérek.

1.3. ábra. A klíringelt pozíciók aránya (Névérték)

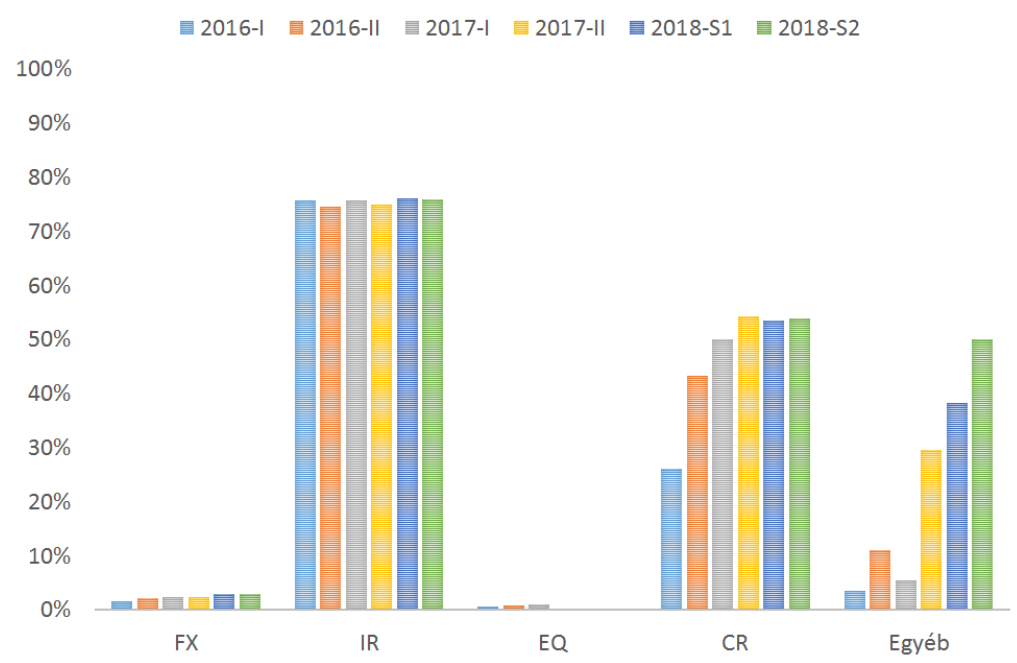

A fố kockázati típusokat a nemzetközi irodalomban használt rövidítésekkel jelöltem. Ennek megfelelően „IR” a kamatláb derivatívákat, „FX” a deviza termékeket, „EQ” a részvény alapú derivatívákat és végül „CR” a hitel derivatívákat jelenti.

A derivatívák kétoldalú kereskedésének egyik leggyakoribb jogi kerete az ISDA keretszerződés (ISDA Master Agreement), amelyet az International Swaps and

${ }^{4}$ Amennyiben ugyanis két kereskedô egymással közvetlenül köt ügyletet, a BIS az adatok tisztításánál képes a termék két oldalát megkülönböztetni, és azt csak egyszer számításba venni. Ha viszont a derivatív klíringházon keresztül lett megkötve, akkor nem világos, hogy melyik a szerzôdés másik oldala. Továbbá az az információ sem áll rendelkezésre, hogy a szerzôdés egy másik kereskedôvel van kötve vagy éppen egy intézményi befektetôvel. A BIS által követendő helyes eljárás a kereskedők közötti klíringelt derivatívák névértékének felezése lenne, ez azonban a fenti okok miatt nem megvalósítható. 
Derivatives Association (ISDA) publikált először 1985-ben. Az azóta már több frissítésen átesett standardizált szerzôdésrendszer $1^{5}$ több dokumentumot is magában foglal, amelyek a két fél között megkötött derivatívák feltételeit részletezik. A feltételek többek között specifikálják a feleket, azok teljesítési kötelezettségeit, a legfontosabb definíciókat, a korai pozíciózáráshoz vezetô okokat és a pozíciózáráskor követendő elszámolási szabályt. A keretszerzôdéshez tartozó egyik opcionális dokumentum a Credit Support Annex (CSA). A CSA a felek közötti letét avagy fedezet szabályait rögzíti. Az ilyen letéti megállapodás célja, hogy csökkentse a csőd esetén fellépő veszteség mértékét. Az elmúlt években a derivatív klíringszabályozása mellett a nemklíringelt derivatívák letétkövetelménye is új szabályozást kapott. Erre és a letéti szerződést meghatározó legfontosabb paraméterekre is részletesen visszatérek. Most azonban az általános fogalmak ismertetése után folytassuk a partnerkockázat fogalmaival.

\subsection{Partnerkockázat alapok}

A dolgozatot a partnerkockázat fogalmával indítottam, amelynek bizonyos elemeit az előzố részben röviden ismertettem. Most folytatom a bevezetést, amely célja, hogy definiáljam a hitelértékelési kiigazítást. E cél elérése érdekében most a partnerkockázat, mint pénzügyi kockázattípus tulajdonságait vizsgálom meg.

Ahogy azt már korábban kifejtettem, a partnerkockázat alatt az OTC piacokon megkötött derivatív szerződések élettartama során, a partnerek lehetséges nemteljesítéséból eredő veszteség kockázatát értem. A definícióban szereplő potenciális veszteséget egy sajátos esemény, a partner nemteljesítése okozza, amely miatt a partnerkockázatot a hitelkockázat egy speciális területének nevezhetjük ${ }^{6}$

A fenti esemény tehát kiemelt szerepet kap a partnerkockázat mérésekor. A dolgozat során csődeseményként ${ }^{7}$ hivatkozott fogalom valójában egy jogi meghatározás, amely események egy halmazát fedi le. A piaci standard szerint a csôdesemény fogalmát az ISDA keretszerződés 5. fejezete rögzíti. A keretszerződés az alábbi nyolc eseményt tekinti csődeseménynek $8^{8}$

1. Teljesítési, vagy fizetési mulasztás

${ }^{5}$ A legutóbbi átdolgozás elérhetô az alábbi linken https://www.isda.org/book/ 2002-isda-master-agreement-english/

${ }^{6}$ Hitelkockázat alatt itt minden olyan pénzügyi veszteség kockázatát értem, amely a partner nemfizetéséból adódik.

${ }^{7}$ Ugyan a magyar szakirodalomban elterjedt a csôdesemény kifejezés, de megjegyezném, hogy ez kissé pontatlan. Csôdesemény alatt valójában egy nemteljesítési eseményt (Event of default) értek, amelynek csak egyik oka lehet a csőd.

${ }^{8} \mathrm{Az}$ alábbi lista az ISDA által, a keretszerződésekhez kibocsátott „használati útmutató"-ból származik, amely letölthetô az alábbi linken:https://www.isda.org/a/lAEDE/ UG-to-2002-ISDA-Master-Agreement.pdf 
2. A keretszerződés feltételeinek megsértése

3. A CSA feltételeinek megsértése

4. Megtévesztés

5. Fizetési mulasztás más, specifikált tranzakciókon

6. Közvetett nemfizetés

7. Csôd

8. Átvállalás nélküli felvásárlás

A dolgozat során a csődesemény modellezésénél egyszerúsített feltételekkel fogok dolgozni, és nem fogom felhasználni a fentebbi megkülönböztetéseket. Ez összhangban áll a téma szakirodalmában követett gyakorlattal, ahol is nem a fentebbi lista eseményeinek bekövetkezését szimulálják, hanem magát a csődeseményt. A modellezési eljárások alapjait az 1.2.2. fejezetben ismertetem. Ennek ellenére a fentebbi lista segíti annak megértését, hogy mennyire szorosan is kapcsolódik a partnerkockázat a hitelkockázathoz.

A partnerkockázat viszont két ponton különbözik a hitelkockázat egy fontos területétől, a klasszikus kölcsönkockázattól. Míg egy hitelszerzôdés során a felek egyértelmúen hitelező és adós kategóriákba oszthatóak, és a hitelező követelése egy jól meghatározott mennyiséggel leírható, addig a partnerkockázat esetén ezek nem teljesülnek (Zhu és Pykhtin, 2007). Mivel egy OTC derivatív szerződés értéke, minden esetben az aktuális piaci faktoroktól függ, így a fennálló tartozás is folyamatosan változik. Ebból adódóan annak értéke akár egyik napról a másikra előjelet is válthat, így felcserélve az adós és a hitelezô szerepét. Éppen ezen okok miatt az úgynevezett kitettség meghatározása egy bonyolult, számításigényes feladat.

A partner nemfizetése miatt bekövetkezett veszteség mértéke függ a derivatív szerződés éppen aktuális értékétől. A piaci faktorok értékének a függvényében a derivatív lehet követelés vagy kötelezettség. Az ISDA keretszerződésben meghatározott csődesemények bekövetkezése után a pozíció zárásának (closeout) a folyamata következik..$^{9}$ A gyakorlati modellezésben az alábbiakat feltételezzük: amennyiben a származtatott termék a túlélô partner kötelezettsége, akkor annak értékét teljes mértékben köteles megfizetni a másik félnek. Ellenkezô esetben a túlélő fél elveszíti a pozíciója értékét és csakis az úgynevezett megtérülési összeget (recovery value) kapja meg. Érdemes már most észrevennünk, hogy a fenti aszimmetria a nemteljesítés opció jellegú természetét okozza. A megtérülési összeget

${ }^{9} \mathrm{Az}$ ISDA keretszerzôdésben meghatározott csôd eseti pozíciózárás elemzését historikus és gyakorlati példák bemutatásával Weeber (2009) valamint Weeber és Robson (2009) elemzik. 
1.1. táblázat. Nettósítás példa: Különböző partnerekkel kötött pozíciók aktuális piaci értéke és a partnerek azonnali csődje miatti veszteség

\begin{tabular}{lccc}
\hline & Partner A & Partner B & Partner C \\
\hline Pozíció 1 & 100 & 20 & 70 \\
Pozíció 2 & -40 & 20 & -30 \\
Pozíció 3 & -30 & 10 & 30 \\
Pozíció 4 & 20 & & -50 \\
Pozíció 5 & 70 & & -40 \\
\hline \hline Veszteség (Nettósítás nélkül) & 190 & 50 & 100 \\
Veszteség (Nettósítással) & 120 & 50 & 0 \\
\hline
\end{tabular}

jellemzően a követelésével arányosnak tekintjük, és egy százalékban megadott értékkel, a megtérülési rátával $(R E C)$ fejezzük ki. A vissza nem szerezhető összeget hívjuk nemteljesítéskori veszteségnek, és annak arányát nemteljesítéskori veszteségrátának $(L G D)$. A dolgozat során az $L G D$ értékét konstansnak tekintem, valamint értelemszerúen az $L G D=1-R E C$ formulával kötöm a megtérülési rátához. A konstans $L G D$ a téma irodalmában rendkívül gyakran elókerülő egyszerûsítő feltételezés. A feltevés feloldható sztochasztikus $L G D$ modellek használatával, amit azonban a dolgozatban nem teszek meg. Az eredmények szempontjából ugyanis az ilyen modellek elhanyagolható mértékú hozzáadott értéket képviselnének, miközben jelentősen növelnék a disszertáció komplexitását.

A csődesemény bekövetkezésének bizonytalansága miatt a feleknek érdekükben áll csökkenteni azokat az eseteket, amikor a partnerük felé fennálló követelésük túl nagy méreteket ölt. Így számos kockázat csökkentő technika már gyakran a kezdeti megállapodásban rögzítésre kerül.

A leggyakoribb ilyen a nettósítási megállapodás, amely az ISDA keretszerződés része. A nettósítást az adott partnerrel megkötött derivatívákon fennálló követelések és kötelezettségek aggregálását jelenti. Az 1.1. táblázatban bemutatok egy példát, amely a nettósítás hatékonyságát érzékelteti. A partnerek azonnali csődje nettósítás nélkül az összes fennálló követelés összegét, sorban 190, 50 és 100 dollár veszteséget jelentene, míg nettósítással ezek az összegek 120, 50 és 0 dollárra csökkennek.10 Láthatjuk, hogy a nettósítás hatékonysága a követelések és kötelezettségek megoszlásán múlik. A „B” partner esetében a nettósítás nem okoz csökkenést a veszteség nagyságában, míg a „C” partner esetében a redukció mértéke maximális. Az „A” partner egy tipikusabb példát mutat, ahol is a nettósítás javít a kockázat szintjén, de teljesen nem tünteti el azt.

${ }^{10}$ A példában az egyszerúség kedvéért feltételeztem, hogy a csôd után a veszteség a teljes piaci értékkel lesz egyenlő, azaz a partnertől semmi megtérítés nem várható. 
A második kockázat csökkentő eljárás a letéti megállapodás, amit a felek a korábban már említett CSA-ban rögzítenek. A letét pénz vagy értékpapír ${ }^{11}$ amely a letétet biztosító fél fizetésképtelensége esetén a túlélő fél rendelkezésére áll, hogy a veszteségét csökkentse. A derivatívák a repókkal együtt kivételt képeznek a hagyományos csődeljárás alól olyan tekintetben, hogy a csôdesemény bekövetkezésekor a rendelkezésre álló fedezet értékesíthetô. Így az akár hosszúra nyúló csődeljárási folyamat során a túlélő felek és a bíróság már csak a letéttel nem fedezett tartozásról tárgyalnak. Ma a szabályozási reformok miatt két típusú letétet különböztetünk meg: a változó letétet és a kezdeti letétet. A változó letét célja a derivatív értékének mindennapos mozgásából adódó lehetséges veszteség ellensúlyozása, míg a kezdeti letét kifejezetten a csődidôponttól a pozíciózárásig bekövetkezô változások ellen véd.

A fennálló követelések úgy is csökkenthetőek, ha a felek hamarabb zárják a szerzôdést és nem várják meg annak lejáratát. Canabarro és Duffie (2004) alapján a szezôrdésben rögzített korai zárásnak több típusa is létezik: Likviditási opcióról beszélünk, amikor a felek előre meghatároznak jövóbeli idôpontokat a származtatott termék lejárata előtt, amikor úgy dönthetnek, hogy felfüggesztik a derivatív szerződést. Más esetben bizonyos hitelminősítési esemény, például egy bizonyos szint alá történő leminősítés bekövetkezéséhez kötik a pozíció zárását. Gregory (2010) még megemlíti az úgynevezett újrakezdési eljárást is, amely szerint a megnövekedett követelést a tartozó fél egy egyszeri fizetéssel lecsökkentheti. Ez a gyakorlat olyan esetekben lehet fontos, amikor a feleknek szükségük van a folytonos pénzáramokra, így például fedezési céllal megkötött derivatívák esetében, hiszen ilyenkor a szerződés megszüntetése egyik félnek sem érdeke.

A követelések csökkentése helyett más módon is lehetôség van a partnerkockázat mérséklésére. Bizonyos esetekben egy harmadik féltól származó garanciával csökkentik a partner csődvalószínúségének hatását. Ezeken túl fontos partnerkockázat redukáló eszköznek számít a korábban már említett derivatív klíring, ahol is a klíringház vállalja a felek partnerkockázatát. Ez a módszer jellemzően standard termékek esetén használt a gyakorlatban. Testreszabott, speciális struktúrák nem alkalmasak arra, hogy klíringházon keresztül kössék óket.

Végül a derivatív fedezése is felfogható, mint partnerkockázat csökkentô eljárás. Természetesen minden újabb kétoldalú megállapodás partnerkockázatot hordoz magában, amit a fedezési stratégia kidolgozásakor figyelembe kell venni.

Ki kell emelni azt a fontos megállapítást, hogy egyik eszköz sem szünteti meg a tranzakciókban lévô kockázatot teljes mértékben. Például Gregory (2010) és

${ }^{11}$ A 2017 végi adatokat feldolgozó ISDA letét felmérés szerint a teljes letét állomány közel háromnegyede volt pénz, és a maradék egynegyed volt értékpapír. Az ISDA által készített felmérés elérhetô az alábbi linken: https://www.isda.org/a/oQmEE/ ISDA-Margin-Survey-Full-Year-2017.pdf 
Gibson (2005) alapján a letéti megállapodás átalakítja a partnerkockázatot múködési, jogi és likviditási kockázattá, amely miatt sok nem pénzügyi szektorban tevékenykedő vállalat nem tudja vállalni a fedezeti megállapodást. Hasonlóan, a klíringház nem megszünteti a partnerkockázatot, hanem részben rendszerkockázattá alakítja azt.

\subsubsection{A kitettség modellezése}

Fentebb kiemeltem, hogy az egyik legfontosabb különbség a partnerkockázat és a hagyományos kölcsönkockázat között a követelések jellegéból adódik. Szemben egy hitelviszonyt megtestesítô szerződéssel, ahol a tartozó féltól követelt összeg a hitel teljes élettartama alatt jól meghatározható, egy OTC derivatív ügylet esetén ugyanez egy bonyolult modellezési feladat eredménye. A feladat formalizálásához tételezzük fel, hogy egy $\left(\Omega, \mathcal{F}, \mathcal{F}_{t}, \mathbb{Q}\right)$ valószínúségi mező́n dolgozunk, ahol $\Omega$ az összes lehetséges kimenet halmaza, $\mathcal{F}$ az összes eseményt lefedô $\sigma$-algebra. A piacon $t$ idôponting elérhetó információt $\mathcal{F}_{t}$ tartalmazza, ahol az $\left(\mathcal{F}_{t}\right)_{t \geq 0}$ filtráció jobbról folytonos és teljes. Végül $\mathbb{Q}$ legyen a kockázatsemleges mérték.

Egy derivatív szerződést annak kifizetés függvényeivel definiálhatunk. Az egyegy időponthoz rendelt kifizetés függvényeket absztrakt pénzáramokként is felfoghatjuk. Így minden pénzáram az alap piaci faktoroktól és az ügylet paraméterezésétől függố valószínúségi változó lesz. A dolgozat során a pénzáramok helyett jellemzően azok diszkontált összegét használom, így az egyszerüsítés kedvéért erre vezetek be egy jelölést, amit Brigo et al. (2013) munkájából kölcsönzök. Így legyen $\Pi(t, T)$ a $t$ és $T$ időpont közötti pénzáramok $t$ időpontra diszkontált összege, ahol $T$ jelöli a derivatív lejáratát, amiról mindig felteszem, hogy véges, azaz $T<\infty$. A dolgozat hátralevô részében feltételezem, hogy a $\Pi(t, T)$ diszkontált pénzáramok a származtatott termék szerződésben meghatározott pénzáramait tükrözik, azaz ezek nemfizetési kockázattól mentesek. Egy alternatív megközelítésmód szerint a $\Pi(t, T)$ két kockázatmentes partner között megkötött pénzáramok jelenérték jelenti.

Eddig a pontig szándékosan igyekeztem elkerülni az alfejezet címében szereplő kitettség fogalom használatát, és helyette követelést vagy éppen aktuális piaci értéket használtam az érvelésben. Most azonban elértem ahhoz a ponthoz, hogy ezt a pontatlanságot feloldjam, hiszen az előzőekben megalapoztam a kitettség fogalmát, amely a partnerkockázat és a hitelminősítési kiigazítás egyik legfontosabb eleme.

A dolgozat során feltételezem, hogy tetszóleges, a dolgozatban tárgyalt derivatív szerződés partnerkockázat mentes értéke előáll az alábbi formában:

$$
V_{t}=\mathbb{E}_{t}[\Pi(t, T)]
$$


ahol $V_{t}$ jelöli a derivatív (kockázatmentes) árát és $\mathbb{E}_{t}[]=.\mathbb{E}\left[. \mid \mathcal{F}_{t}\right]$ a $t$ időpontban elérhetô információra vett $\mathbb{Q}$ mérték szerinti feltételes várható értéket. A dolgozat során amennyiben a $t=0$ speciális esetet vizsgálom, akkor $\mathbb{E}_{0}[$.$] helyett az$ $\mathbb{E}[$.$] egyszerúsített jelölést használom. Amennyiben ismert a derivatív értéke a$ $t$ idôpontban, akkor definiálható az akkori kitettség értéke, amire az $E_{t}$ jelölést használom:

$$
E_{t}=\max \left(V_{t}, 0\right)=\left(V_{t}\right)^{+} .
$$

Tehát a partner felé fennálló kitettség értéke a derivatív árának pozitív része. Fontos megjegyezni, hogy a kitettség, mint ahogyan az ár is, függ a nézôponttól, azaz attól, hogy melyik fél is számolja azt.

A jelen pillanatban fennálló úgynevezett aktuális kitettség meghatározása is egy érdekes, komplex feladat. A partnerkockázat kezelésekor azonban sokszor az a kérdés merül fel, hogy hogyan alakulhat a jövôbeli kitettség. Természetesen erre a válasz az, hogy attól függ, hogy az árat meghatározó piaci faktorok milyen értéket vesznek fel. Egyelöre elég azt látnunk, hogy a kitettség értéke tetszóleges $t$ idôpontra meghatározható, ha ismerjük a piaci faktorok útját addig a pontig.

A kitettséget rendszerint partner szinten számolják, így ha egy partnerrel több derivatív szerződés is fennáll, akkor a kitettség értéke nettósítás nélkül az egyes derivatív szerződésen számolt kitettségek összege, azaz:

$$
E_{t}=\sum_{i \in P T I}\left(V_{t}[i]\right)^{+}=\sum_{i \in P T I} E_{t}[i]
$$

ahol PTI jelöli a partnerrel megkötött származtatott termékek indexeinek a halmazát és $V_{t}[i]$ illetve $E_{t}[i]$ az $i$. árát és kitettségét. A partnerszintú kitettség nettósítással a partnerrel megkötött derivatívák árának összegének a pozitív részére csökken:12

$$
E_{t}=\left(\sum_{i \in P T I} V_{t}[i]\right)^{+}
$$

A jelölések egyszerúsítése miatt a továbbiakban visszatérek az egy pozíciós partnerek elemzésére. Minden a késóbbiekben kifejtett érvelés igaz marad több pozíció esetén is.

Következô lépésként illesszük be a változó letétet a kitettség modellezésébe. Az egyszerüsítés kedvéért tételezzük fel, hogy a derivatív két oldalán alló feleket B-nek és C-nek nevezzük. Jelölje B szemszögéből a letét $t$ időpontban előírt egyenlegét $C_{t}$. Amennyiben $C_{t}$ pozitív (negatív), akkor azt mondjuk, hogy B fedezetet kap C-tól (ad C-nek). A fedezet legfontosabb célja, hogy megakadályozza, hogy valamelyik félnek túl nagy kitettsége keletkezzen a másik felé. A CSA típusától függően a megállapodás lehet egyoldalú, vagy kétoldalú. Egyoldalú esetben

${ }^{12}$ Feltételezve, hogy minden származtatott termék bekerülhet egy nettósítási csoportba. Ez nem minden esetben lehetséges, ugyanis a derivatív kockázat típusa ezt meggátolhatja. 
csak az egyik fél köteles letétet biztosítani, amennyiben kötelezettsége lép fel, míg kétoldalú esetben az éppen tartozó fél fog letétet küldeni. Kétoldalú CSA esetén a $t$ pillanatban fennálló kitettség definícióját az alábbiak szerint módosíthatjuk:

$$
E_{t}=\left(V_{t}-C_{t}\right)^{+}
$$

Ideális esetben a fenti egyenletben $V_{t}$ és $C_{t}$ minden pillanatban megegyeznek, azaz az adós mindig pontosan a tartozásának megfelelő mennyiségú fedezetet tart a letéti számlán. Ezt az esetet nevezhetjük tökéletes CSA megállapodásnak, avagy az ezen a feltételezésen alapuló modellezést Pykhtin (2009a) alapján hívhatjuk naív megközelítésnek. Egy ilyen tökéletes szerződést azonban az óriásira növô múködtetési költségek miatt nem hatékony fenntartani. Így a CSA számos eszközt felhasználva enyhít a letéti feltételeken. Így például a felek minimális küszöbértékeket állítanak be, amely alatt a kitettség nincs fedezve, vagy éppen elhagyják a fedezeti számlán történő kisebb kiigazításokat úgynevezett minimális utalási összeg bevezetésével, továbbá előfordul, hogy a fedezet elvárt összegét kerekítik (Gibson, 2005). Az így bevezetett enyhítések mind a fedezet költségének mérséklését célozzák, amelynek egyfajta melléktermékeként a letét hatékonyságát rontják és így növelik a partnerkockázatot. Számos esetben a CSA feltételek nem szimmetrikusak a felek között. Így például szokás egy kétoldalú szerződést egyoldalúsítani azáltal, hogy az egyik félre vonatkozó minimális küszöbérték szintjét sokkal magasabbra állítják, mint a másikét. Ezek az aszimmetrikus feltételek természetesen az egyoldalú CSA megállapodáshoz hasonlóan rontják az egyik fél által elérhető kitettség csökkentés hatékonyságát.

A fentieken túl a CSA megállapodás rögzíti a letéti hívás küldésének a gyakoriságát, azaz azt az idő intervallumot, amely elteltével újraellenőrzik a letéti számla egyenlege és a derivatív aktuális értéke közötti különbséget és újabb letétet kérnek. Andersen et al. (2017b) alapján a letéti hívás küldése nagyobb pénzügyi intézmények között napi szintű gyakorisággal történik, azonban más esetekben sokkal ritkábban, gyakran hetente vagy havonta.

Érezhetjük, hogy a fenti tökéletlenségek növelik a kitettség értékét: Minél nagyobb a minimális letéti küszöbérték, annál nagyobbra nôhet a kitettség, mielótt letétet kérne az egyik fél, avagy minél ritkább a letéti hívás, a kitettség értéke annál jobban eltávolodhat a rendelkezésre álló letét értékétól. Ezen szerzôdéses megállapodások mellett azonban van egy állandó, a letét hatékonyságát rontó tényezô, amelyet mindig szerepeltetni kell egy CSA megállapodással kiegészített származtatott termék kitettségének a modellezésében. Vizsgáljuk meg most ezt.

A kitettség modellezésnek klasszikus megközelítése szerint a pozíció zárásakor a ténylegesen rendelkezésre álló margin egyenlege $\left(K_{t}\right)$ különbözni fog attól, amit a CSA arra az időpontra előírna $\left(C_{t}\right)$. A különbség oka, hogy a CSA által szabályozott letét küldése nem folytonos. A partner utolsó aktív tevékenysége és a pozíció 
likvidálása meghatároz egy ablakot, amelyen belül a kitettség nagysága még CSA megállapodás mellett is szabadon mozoghat. Ezt az időbeli intervallumot margin periódusnak (MPR) nevezik és a legutolsó margin küldésének időpontjától a pozíció zárásáig eltelt periódusként definiálhatjuk. A margin periódust szokás egyfajta türelmi idôszaknak is tekinteni, amely garantál egy bizonyos idôt a letéti hívást kapó félnek, hogy teljesítse a kötelezettségét. Így például a margin periódus célja, hogy egy átmeneti likviditási probléma miatt elmulasztott letét küldés ne eredményezzen azonnali csődeseményt. Ez viszont azt jelenti, hogy amennyiben a fél nem tud teljesíteni, akkor a tényleges csődesemény csupán a margin periódus után lesz elismerve. Jelöljük a margin periódus hosszát $\zeta$-val. Ekkor a klasszikus modell által adott kitettséget az alábbi formában definiálhatjuk:

$$
E_{t}=\left(V_{t}-K_{t}\right)^{+}
$$

ahol

$$
K_{t}=C_{t-\zeta}
$$

Tehát a pozíció zárásakor a rendelkezésre álló margin egyenlege megegyezik az MPR elején előírt egyenleggel, hiszen közben nem történt újabb befizetés. Az egyenletek alapján könnyen láthatjuk, hogy minél hosszabb a margin periódus a portfólió értéke annál jobban eltávolodhat a fedezeti számlán lévô összegtól. Így megállapíthatjuk, hogy az átlagos kitettség is a margin periódussal arányosan nô. A margin periódus hossza a letéti feltételeken is múlik, de standard piaci gyakorlatként, még napi letéti hívás gyakoriság mellett sem rövidebb 10 munkanapnál (Pykhtin, 2009b).

Az így kapott modell intuitív és széles körben elterjedt. A dolgozat során többször felhasználom ezt a megközelítésmódot. A legújabb munkák azonban felhívják a figyelmet, hogy érdemes jobban megvizsgálni a fenti egyenleteket. Azok ugyanis számos hibát rejtenek, ahogy arra Andersen et al. (2017b) mutattak rá. $\mathrm{Az}$ 1.7. egyenlet mögötti érvelés szerint a bajba jutott partner nem fogja teljesíteni a margin kötelezettségeit, így a számla egyenlege megragad a margin periódus elején lévố egyenlegnél. Valójában az 1.7. egyenlet ennél többet állít, hiszen azt feltételezi, hogy a túlélő fél sem fog többé fedezetet küldeni. Világos azonban, hogy a portfólió piaci értékének mozgása miatt bármikor előfordulhat olyan eset, hogy a margin periódus elejét követô elsô letéti hívást éppen a túlélő fél kapja, akinek ilyenkor semmi oka nincs arra, hogy annak ne tegyen eleget. Tehát az 1.7 . egyenletet finomítani kell. Továbbá az 1.6. egyenlet is hibát rejt magában, hiszen azt feltételezi, hogy a margin periódus alatt a felek minden, a pozíción adódó pénzáramot megfizetnek. Ez a feltétel a margin periódus végén, amikor az egyik partner fizetésképtelensége már világossá vált, biztosan nem elfogadható. A jellemzően kéthetes ablak elején ugyan a túlélő fél még feltételezhetően fizetni fog, 
de csekély a valószínûsége, hogy a másik fél egy kihagyott margin hívás után is így tenne. Ha követjük Andersen et al. (2017b) levezetését, akkor bevezethetjük az elmaradó pénzáramokat is a kitettséget leíró modellbe. Legyen $\Pi^{x}\left(t_{3},\left(t_{1}, t_{2}\right]\right)$ a $t_{1}$ és $t_{2}$ között esedékes, de nem kifizetett pénzáramok $t_{3}$-ban vett értéke, ahol $x$ mutatja a pénzáramok irányát. Így $x \in\{B \rightarrow C, C \rightarrow B$, net $\}$, ahol $B \rightarrow C$ a B-től C-felé, $C \rightarrow B$ a C-tôl B-felé fizetendő és net a nettó pénzáramokat jelenti. Ez alapján megadhatjuk a klasszikus modell egy szélsőséges változatát, amely szerint az MPR alatt egyáltalán nincs pénzáram. Így az 1.6. egyenlet az alábbi formát veszi fel:

$$
E_{t}=\left(V_{t}+\Pi^{n e t}(t,(t-\zeta, t])-C_{t-\zeta}\right)^{+} .
$$

Ezt Andersen et al. (2017b) alapján ,klasszikus-" modellnek nevezhetjük. Ha az általuk adott fejlett modellhez szeretnék eljutni, akkor $\mathrm{C}$ csődeseménye esetén az alábbi idôvonalat kell megadnunk : $t_{C}=t-\zeta_{C}$ jelenti a $\mathrm{C}$ által utoljára teljesített margin letét idejét, $t_{B}=t-\zeta_{B}$ a $\mathrm{B}$ által utoljára teljesített margin letét ideje, $t_{C}^{\prime}=t-\zeta_{C}^{\prime} \mathrm{C}$ utolsó pénzáram fizetésének ideje, $t_{B}^{\prime}=t-\zeta_{B}^{\prime} \mathrm{B}$ utolsó pénzáram fizetésének ideje. Az események fenti sorrendje mellett átalakíthatjuk a kitettség értékét meghatározó egyenleteket. Először javítsuk ki az 1.7. egyenletet:

$$
K_{t}=\min _{\hat{t} \in\left[t_{C}, t_{B}\right]} C_{\hat{t}}
$$

Így már figyelembe vesszük, hogy a margin periódus elején B teljesíteni fogja a hozzá érkezố margin hívásokat. Az idôvonal alapján az 1.6. egyenlet pedig az alábbi formát veszi fel:

$$
E_{t}=\left(V_{t}-K_{t}+\Pi^{C \rightarrow B}\left(t,\left(t_{C}^{\prime}, t_{B}^{\prime}\right]\right)+\Pi^{n e t}\left(t,\left(t_{B}^{\prime}, t\right]\right)\right)^{+},
$$

hiszen a $\left(t_{C}^{\prime}, t_{B}^{\prime}\right]$ intervallumon $\mathrm{C}$, míg a $\left(t_{B}^{\prime}, t\right]$ intervallumon egyik fél sem fizeti az éppen aktuális pénzáramokat. ${ }^{13}$

A jövôbeli kitettség nagyon változatos tud lenni. Így ahelyett, hogy egy-egy speciális esetre koncentrálnánk, célszerü a jövôbeli kitettség eloszlását vizsgálni. Néhány, a partnerkockázat-kezelés során gyakran felhasznált eszköz - többnyire praktikus okok miatt - az eloszlást annak bizonyos statisztikai mennyiségeivel

13 Andersen et al. 2017b munkája különös alapossággal számol be a kitettség modellezés legapróbb részleteiról is. Azontúl, hogy megkérdőjelezik a közel két évtizeden át elfogadott klasszikus modellt, rámutatnak arra a tényre is, amit jellemzően az irodalom figyelmen kívül hagy. A CVA kiértékelésénél csúsztatottan kell felhasználni a túlélési valószínúséget. Hiszen a partner fizetésképtelensége már a margin periódus elején bekövetkezik, és csak annak felismerése és a derivatív zárása kerül a margin periódus végére. Így a $t$-ben számolt várható kitettséget a $t-\zeta$ idôpontbeli túlélési valószínűséggel kell párosítani. Megjegyezzük, hogy ez az eltérés jellemzően nem okoz szignifikáns változást a CVA értékében. 
írják le. Ezek a kitettséget meghatározó kockázati mérőszámok, amelyeket most formálisan is definiálok.

Elsóként szokás a korábban bevezetett kitettség fogalom jelen pillanatbeli értékét megkülönböztetni, és ahhoz saját nevet rendelni. Így az $E_{0}$ értéket azonnali kitettségnek hívják, ami miatt általában a $C E$ jelöléssel hivatkoznak rá:

$$
C E=E_{0}
$$

A partnerkockázat monitorozásának egyik legfontosabb eszköze a partnerszintú limitek felállítása. A limitekhez gyakran a jövóbeli kitettség egy magas kvantilisét hasonlítják, amit Potenciális Jövóbeli Kitettségnek ( $P F E)$ neveznek és egy $\alpha$ szignifikancia szinttel együtt az alábbi formában definiálhatunk:

$$
P F E^{\alpha}(t)=\inf \left\{x: \mathbb{P}\left(V_{t} \leq x\right) \geq \alpha\right\}
$$

ahol $\mathbb{P}$ a valós valószínúségi mérték. Azaz $P F E^{\alpha}(t)$ egy VaR-szerú mérôszám és megadja azt a szintet, amit a derivatív $t$-beli értéke $1-\alpha$ valószínúséggel halad meg. A PFE profil teljes $[0, T]$ intervallumon vett maximumát Maximális Potenciális Jövóbeli Kitettségnek (MPFE) nevezik.

Többek között például Cesari et al. (2009) is megemlítik a VaR alapú PFE egy alternatíváját, a kitetsséget leíró Expected Shortfall-t:

$$
E S^{\alpha}(t)=\mathbb{E}^{\mathbb{P}}\left[V_{t} \mid V_{t} \geq P F E^{\alpha}(t)\right],
$$

ahol $\mathbb{E}^{\mathbb{P}}$ a $\mathbb{P}$ mérték alatt számított várható érték.

Ennél a pontnál eljutottunk a dolgozat során egyik legtöbbet használt mennyiséghez, a várható kitettség fogalmához. A várható kitettség, az előző fogalmakhoz hasonlóan egy időtől függő mennyiség. A $t$. időpontban vett értékét a $t$. idôpontbeli kitettség jelenből vett, egyszerú várható értékeként definiálhatjuk:

$$
E E(t)=\mathbb{E}^{y}\left[E_{t}\right]
$$

ahol y érzékelteti, hogy a várható értéket a számítás céljától függóen lehet a valódi $(y=\mathbb{P})$ és a kockázatsemleges $(y=\mathbb{Q})$ mérték alatt is számolni. Hagyományos partnerkockázat-kezeléshez vagy tókeképzéshez a valódi mérték alatti mennyiséget, míg amint azt hamarosan látni fogjuk a hitelértékelési kiigazításhoz a kockázatsemleges mértéket használjuk.

A várható kitettség fontosságának érzékeltetéséhez Pykhtin (2009b) három felhasználási területet nevez meg: A partnerkockázat árazása és fedezése, a hitelegyenértékes mérték meghatározása a gazdasági tóke számolásához és a szabályozói tôkeszámítás során felhasznált nemteljesítéskori kitettség számítása.

Így számos esetben - például szabályozói tókeszámításkor vagy éppen a hitelértékelési kiigazítás meghatározásakor - nem kifejezetten egy adott jövőbeli 
idôpont várható kitettségére vagyunk kíváncsiak, hanem a teljes hátralévő időtartam várható kitettségére. Ilyenkor a $E E($.$) leképezés [0, T]$ intervallumon vett képére, mint várható kitettség profilra hivatkozunk.

A teljes profil egy számra történő tömörítésére gyakran annak idő intervallumokkal súlyozott átlagát használják, amit átlagos pozitív kitettségnek (EPE) nevezünk :

$$
E P E=\frac{1}{T} \int_{0}^{T} E E(t) d t
$$

Az átlagos pozitív kitettséget hitel-egyenértékesnek is hívják, hiszen kisimítja a várható kitettség alakját, így az jobban összemérhető egy egyszerú kölcsönszerzôdésból adódó kitettséggel.

Végül a várható kitettség profil esetében figyelembe vehetjük az idôtényezőt, így definiálhatjuk a várható diszkontált kitettség profilt:

$$
E E^{*}(.):=t \rightarrow \mathbb{E}\left[D(0, t) E_{t}\right]
$$

ahol $D(0, t)$ a 0 és $t$ közötti diszkontfakor. A hitelértékelési kiigazítást ismertető fejezetben újra találkozunk ezzel a mennyiséggel.

Ezzel befejezem a kitettség modellezését bemutató fejezetet. Fontos látnunk, hogy a kitettség modellezése egy komplex feladat, amely alapjait még nemrégiben is újraírták, holott a modellezési gyakorlat messzire nyúlik vissza: A jövóbeli kitettség (PFE) modellezésének instrukcióit és a modellekkel szemben támasztott elvárásokat az elsók között Canabarro és Duffie (2004) munkája foglalta össze. Canabarro és Duffie (2004) a PFE modellek három legfontosabb felhasználási területének az alábbiakat nevezték meg: Az ügyletek jóváhagyásakori limit monitorozása, gazdasági és szabályozói tóke számítása és hitel/partnerkockázat árazása. Véleményük szerint a hitel és a partnerkockázat árazás a hitelkockázat-kezelés elsố védelmi vonala, ahol is az alulárazott hitelkockázat az adott partnerrel kötött ügyletek felhalmozódásán keresztül súlyos veszteségekhez vezethet.

A letéti megállapodás kitettségre gyakorolt hatását is számos korai munka elemzi. Gibson (2005) tanulmánya egy egyszerúsített modellkeretben vizsgálta a fedezet átlagos pozitív kitettségre gyakorolt hatását. Egyik fő eredménye szerint a portfólió piaci értékére véletlen bolyongást, valamint standard paraméterekkel rendelkező egyoldalú CSA meglétét feltételezve az EPE értéke 80\%-kal csökkenthető. Továbbá a fenti modellben a fedezett EPE jól közelíthető, mint a fedezetlen EPE és a margin periódus négyzetgyökének a szorzata, ami egy egyszerú szabályt ad a margin periódus változásból adódó hatások gyors számszerúsítésére.

A szabályozói partnerkockázati tôketartalékolás nemteljesítéskori kitettségének modellezési kérdéseit elemezte Pykhtin és Zhu (2006) munkája. A szerzők a lehetséges modellezési eljárások részletes leírása mellett egy egyszerúsített eljárást 
is bemutatnak a fedezeti megállapodással ellátott termékek kitettség számításának gyorsítására, bizonyos szigorú feltételeket bevezetve a kitettség eloszlására.

Az eloszlásra tett szigorú feltételeket valamelyest Pykhtin (2009b) enyhítette, aki CSA melletti kitettség számítására mutat egy szemi-analitikus módszert. Az eljárás elônye, hogy a letét hatásának számszerúsítéséhez nincs szükség a letét nélküli szimulációban használt pontok megduplázására, feltéve, ha a letétet meghatározó portfólió értékének a portfólió jelenlegi értékére vett feltételes eloszlása normális.

Andersen et al. (2017b) munkája a korábbi megközelítésmód hibáira világít rá. Az általuk javasolt modellben a várható pozitív kitettség profil még változó letét mellett sem csökken szignifikánsan, ugyanis a profil egyes pontjainál ugrások keletkeznek. Ezek az ugrások már egyedi pozíciókra is, de fóképp portfóliók esetében lényegesen magasabb jövóbeli kitettséget generálnak. Az Andersen et al. (2017b) által bemutatott tényezókre a szabályozók is felfigyeltek, akik újonnan emiatt fejlettebb modellezési gyakorlatokat követelnek meg a bankoktól. ${ }^{14}$

Ebben az alfejezetben megadtam a kitettség modellezésének elméleti alapjait. A fenti szemi-analitikus formulák azonban további komplexitást rejtenek magukban: Azok meghatározása sok esetben analitikusan nem megvalósítható. A kitettség különböző mértékeinek meghatározásához komplex számítási technikákra van szükség. Ezek a numerikus technikák azonban jelentôs számítási kapacitást igényelnek. A számítási kapacitás a hitelértékelési kiigazítás számításakor tovább fokozódik, hiszen annak csupán egyik komponense a kitettség. A becslési eljárások részleteivel a dolgozat a 2 , fejezete foglalkozik.

\subsubsection{A csődesemény modellezése}

Ebben az alfejezetben a csődesemény modellezésének leggyakoribb módszereit és az azokhoz tartozó szakirodalmat tekintem át. A csődesemény részletes jogi leírását már korábban megadtam, de már akkor jeleztem, hogy a dolgozat során egy egyszerúbb szemléletmóddal fogom ezt a problémát megközelíteni. A csődesemény egy véletlen esemény, amelyet a kvantitatív modellekben annak idôpontján keresztül jellemzünk. Ezt az idôpontot csődidôpontnak (default time) hívjuk és jellemzően $\tau$-val jelöljük. A szakirodalomban az elmúlt évtizedek alatt kialakult két modellezési megközelítés, amelyek célja a csődidőpont és a csődvalószínúségek meghatározása. Ezeket strukturális és redukált formájú modelleknek nevezzük. A dolgozat során a gyakorlatban szélesebb körben elterjedt redukált formájú modelleket fogom használni. Azok könnyebb érthetôsége érdekében és a fejezet irodalmi

${ }^{14} \mathrm{Az}$ ECB 2017 decemberében publikált részletes útmutatóját az alábbi linken lehet elolvasni https://www . bankingsupervision.europa.eu/banking/letterstobanks/shared/pdf/ 2017/ssm.egam_guide_draft.en.pdf 
összefoglaló jellege miatt azonban most mégis a strukturális modellek rövid ismertetésével kezdem. Majd csak azután térek vissza a redukált formájú modellekhez.

A strukturális modellek Merton (1974) munkájából eredeztethetőek. Merton (1974) hitelkockázattal rendelkező vállalati kötvény árazását végezte el, amelyhez felhasználta a korábban általa (Merton (1973)) és Black és Scholes (1973) által levezetett európai típusú opciók árazási formuláit és a hozzájuk tartozó feltételeket. Ennek eléréséhez a legfontosabb lépés a vállalat saját tőkéjének, mint egy európai típusú vételi opciónak felírása volt. Ha ugyanis a vállalatnak csak egyetlen kibocsátott diszkontkötvénye (kötelezettsége) valamint saját tőkéje van, és a kötvény lejáratakor annak névértékét teljesíteni kell - különben a vállalat részvényesei a hitelezók javára elvesztik tulajdonukat - akkor az alábbi megállapítás tehetô: A vállalat saját tókéje a lejárat pillanatában a vállalat értéke és a kötvény névértéke közötti különbség pozitív részét éri. Merton (1974) az opció árazási munkákból átemelte az ott használt feltételeket, köztük azt is, hogy a vállalat értéke geometriai Brown mozgás szerint alakul. Így egy, az európai vételi opció árazásához teljesen ekvivalens problémát kapott, amelyból a vállalati kötvény értéke már meghatározható. Merton (1974) modellje így már megjeleníti a csődesemény lehetôségét, de az csakis a kötvények lejáratakor következhet be.

Ezt a hiányosságot Black és Cox (1976) javították, akik feltételezték, hogy a hitelszerződésbe épített védelmi mechanizmusok meggátolják, hogy a vállalat értéke szabadon mozogjon annak újrastrukturálása nélkül. Így bevezetnek egy determinisztikus alsó korlátot, amely a vállalat azon értéke, amely korai csődeseményhez vezet. A vállalati kötvény értékeléséhez tehát nem egy vételi opciót, hanem egy barrier opciót kell árazni.

Merton (1974) úttörô munkáját számos tanulmány javította Black és Cox (1976) mellett. Merton (1974) egyik korai kritikája a vállalat finanszírozási formájának túlegyszerúsítése volt, amelyet Geske (1977) próbált feloldani. Ố diszkontkötvény helyett egy kupont fizetô kötvényt tételezett fel, amellyel a lehetséges csôdesemények halmazát is bơvítette. Ebben a modellben ugyanis bármelyik kuponfizetés egy opciót jelent a vállalat részvényeseinek, hogy csődre ítéljék a céget vagy megtartsák azt a következő kuponfizetésig. Az így kapott modell szerint a vállalat részvényesei egy többszörös opciót tartanak, amelynek árazását Geske (1979) végezte el.

Egy másik kritika szerint Merton (1974) vagy éppen Black és Cox (1976) modelljében a csődesemény nem számít meglepetésnek. Mivel mindkét esetben a vállalat értéke geometriai Brown mozgás szerint alakul, így a csődesemény előrejelezhetô. Leegyszerúsítve, mindig találhatunk küszöbértékek egy sorozatát, amelyet a csődesemény elôtt a vállalat értékének át kell lépnie. A probléma feloldható, amennyiben a vállat értékére ugró-diffúziós folyamatként gondolunk. Ilyen meg- 
oldás található Schönbucher (1996), Zhou (1997) és Delianedis és Geske (2001) munkáiban.

A determinisztikus kamatláb helyett sztochasztikus kamatfolyamatot bevezetve javítható a modell realitása, valamint a csődesemény és a kamat korrelációja is beépíthetố a modellbe. Kim et al. (1988) Cox-Ingersol-Ross, míg Nielsen et al. (1993) és Longstaff és Schwartz (1995) Vasicek kamatlábfolyamatot használva bơvítik Black és Cox (1976) modelljét. Természetesen a kamatlábfolyamathoz hasonlóan a csődeseményt meghatározó küszöbérték is sztochasztikussá változtatható. Brigo és Morini (2006) ezzel próbálták a modellbe építeni a vállalat által elrejtett információk hatását.

A korai munkákat óriási számú tanulmány követte, amelyeket mind a strukturális modellek kategóriájához sorolunk. A strukturális modellek családján belül a Black és Cox (1976) módszertanára épülô modelleket úgynevezett elsô áthaladási idô (first passage time) alapú modelleknek nevezzük. Ezekre általánosan igaz, hogy a csődeseményt a vállalat értékének egy bizonyos küszöbön történő átlépése jelenti, amely megtartja az opció árazási problémára való visszavezethetôséget. A strukturális modellek tehát összekötik a vállalat gazdasági tulajdonságait annak csődeseményével, amely miatt szokás azokat vállalati érték alapú modelleknek is nevezni. Mivel a strukturális modellek nem szolgálják a dolgozat szerves részét, így azok ismertetését ennél a pontnál befejezem. Az érdeklődő Olvasó további részleteket talál Bielecki és Rutkowski (2013) monográfiájában. Most áttérek a dolgozatban felhasznált modellek technikai ismertetésére.

A csôdesemény modellezésének második megközelítésmódja az úgynevezett redukált formájú modellek. Ezekben a modellekben a $\tau$ csődidőpont egy Poisson folyamat elsố ugrásának az ideje. Schönbucher (2003) átfogó munkáját követve a legfontosabb fogalmakat egyszerúbb Poisson folyamatokon ismertetem, majd azokat általánosítva jutok el a gyakorlatban népszerú redukált formájú csődmodellekhez.

Az $N(t)$ homogén Poisson folyamat egy egész értékú, nemcsökkenô sztochasztikus folyamat, amely növekményei függetlenek, $N(0)=0$ és tetszóleges $0 \leq t \leq$ $\leq T$ esetén fennáll az alábbi tulajdonság:

$$
\mathbb{Q}[N(T)-N(t)=n]=\frac{1}{n !}(T-t)^{n} \lambda^{n} e^{-(T-t) \lambda},
$$

ahol $T<\infty$ és $\lambda>0$ a folyamat intenzitása. Az 1.17. egyenlet intuitív megértéséhez Schönbucher (2003) által adott magyarázatot követhetjük. Ha ugyanis feltételezzük, hogy az $N(t)$ folyamat egy rövid $\Delta t$ periódus alatt történô ugrásának valószínúsége arányos a $\lambda$ intenzitással, azaz

$$
\mathbb{Q}[N(t+\Delta t)-N(t)=1]=\lambda \Delta t,
$$


akkor egyszerúen levezethetjük $[t, T]$ intervallumon történő egyszeri ugrás valószínüségét. Amennyiben a $[t, T]$ intervallumot $n$ darabra osztjuk, azaz $\Delta t=\frac{T-t}{n}$, akkor

$$
\begin{aligned}
& \mathbb{Q}[N(T)-N(t)=1]=\left(\begin{array}{c}
n \\
1
\end{array}\right)(\lambda \Delta t)(1-\lambda \Delta t)^{n-1}= \\
& \quad n\left(\lambda(T-t) \frac{1}{n}\right) \frac{\left(1-\frac{1}{n}(T-t) \lambda\right)^{n}}{\left(1-\frac{1}{n}(T-t) \lambda\right)} \stackrel{n \rightarrow \infty}{\longrightarrow}(T-t) \lambda e^{-(T-t) \lambda},
\end{aligned}
$$

ahol az első egyenletnél felhasználtam a növekmények függetlenségét. Tetszóleges $n$ esetén a fentebbi határátmenettel levezethetô az 1.17. egyenlet, amelyhez Schönbucher (2003) részletes leírását ajánlom. A fentiek alapján a $\tau$ csődidőpontot az alábbiak szerint formalizálhatjuk:

$$
\tau=\inf \{t \in(0, T]: N(t)-N(0)>0\} .
$$

Így bevezethetjük az egyik kulcsfontosságú fogalmat, a túlélési valószínûséget. Egy tetszőleges $[t, T]$ intervallumon történő túlélés valószínűségét az alábbiak szerint adhatjuk meg, feltételezve, hogy korábban nem történt csődesemény:

$$
\mathbb{Q}[N(T)-N(t)=0 \mid N(t)=0]=e^{-(T-t) \lambda} .
$$

Amint láthatjuk a $\lambda$ intenzitás paraméter kiemelt szerepet játszik a csődesemény modellezésében és a túlélési valószínúség meghatározásában. Emiatt szokás a redukált formájú modelleket intenzitás alapú csôdmodelleknek is nevezni.

A fentebbi modell elsố természetes kiterjesztése, ha bevezetjük, hogy az intenzitás értéke időben determinisztikusan változhat. Ez lehetőséget teremt a modell a piacon megfigyelt hitelmulasztási ügylet felárakhoz történő kalibrálásához.

Az idôtôl függő $\lambda(t)>0$ paraméter bevezetésével egy inhomogén Poisson folyamatot kapunk. A korábban leírt tulajdonságok igazak maradnak, de figyelembe kell venni, hogy a $\lambda$ mostantól már nem egy paraméter, hanem egy idótól függó $\lambda($.$) függvény. Így például az 1.22$. egyenletben adott túlélési valószínűség a következő alakot veszi fel:

$$
\mathbb{Q}[\tau>T]=\mathbb{Q}[N(T)=0]=e^{-\int_{0}^{T} \lambda(s) d s},
$$

ahol a $\Lambda(T)=\int_{0}^{T} \lambda(s) d s$ növekvő folyamatot kumulált intenzitás folyamatnak hívják. Érdemes észrevenni, hogy az így kapott formula teljes mértékben megegyezik a kamatláb modellezésnél használt diszkontfaktor folyamattal. Ezáltal a kamatláb modellezés terjedelmes szakirodalmában elért eredmények rögtön felhasználhatóak a csődesemény szimulálásakor. Ez az egyik tulajdonság, ami olyan népszerúvé teszi az intenzitás alapú modellezést.

Másrészt Brigo et al. (2013) alapján megjegyezhetjük, hogy a Poisson folyamatok ugrási idejét a saját kumulált intenzitás folyamatba helyettesítve egy 1 
várható értékú exponenciális eloszlású valószínúségi változót kapunk:

$$
\Lambda(\tau)=\mathcal{E} \sim \operatorname{Exp}(1)
$$

Mivel $\Lambda($.$) invertálható, ezért felírhatjuk az alábbi összefüggést is, amely egy$ lehetséges eljárást ad a csődesemények szimulálására.

$$
\tau=\Lambda^{-1}(\mathcal{E})
$$

A determinisztikus kiterjesztés utáni következő lépés a sztochasztikus intenzitás folyamat, amely célja, hogy figyelembe vegyük a hitelfelár volatilitását. A sztochasztikus intenzitással ellátott Poisson folyamatok saját nevet is kaptak, amelyeket így Cox folyamatnak, vagy az így kapott modelleket duplán sztochasztikus csődmodellezésnek nevezünk. A precízebb definícióhoz be kell vezetnünk a piacon elérhetô információk egy számunkra kedvező csoportosítását. Feltételezzük, hogy a piacon $t$ időpontban elérhetô információk halmaza $\left(\mathcal{G}_{t}\right)$ szétválaszható, azaz $\mathcal{G}_{t}=\mathcal{F}_{t} \vee \mathcal{H}_{t}$, ahol $\mathcal{H}_{t}=\sigma(\{\tau \leq u\}: u \leq t)$, azaz $N(t)$ folyamat által generált szigma algebra és az $\left(\mathcal{F}_{t}\right)_{t>0}$ sorozat a piacon megfigyelhető összes további faktor által generált szigma algebrák jobbról folytonos és teljes filtrációja.

A $\lambda(t)$ sztochasztikus intenzitással ellátott $N(t)$ folyamatot Cox folyamatnak nevezzük, ha feltételezve a piaci változók ismeretét $\left(\mathcal{F}_{t}\right), N(t)$ egy inhomogén Poisson folyamat $\lambda(t)$ intenzitással.

A Cox folyamat nagyobb rugalmasságot enged a modellezésben, viszont figyelnünk kell a túlélési valószínúség megfelelô definiálására. Ugyan a folyamat várható megváltozása formálisan nem változik:

$$
\mathbb{E}\left[d N(t) \mid \mathcal{G}_{t}\right]=\lambda(t) d t
$$

de itt a $\lambda($.$) már egy sztochasztikus folyamat, így a túlélési valószínúség meg fog$ változni:

$$
\mathbb{Q}[\tau>T]=\mathbb{Q}[N(T)=0]=\mathbb{E}\left[e^{-\int_{0}^{T} \lambda(s) d s}\right] .
$$

Ismét rámutatva a kamatlábmodellekkel fennálló analógiára, a fenti egyenlet éppen a $T$ időpontban lejáró diszkont kötvény ára. Ez a mennyiség számos kamatlábmodellben analitikusan számítható. Így a $\lambda($.) dinamikájának pozitív kamatláb folyamatot választva kiszélesíthetjük a rendelkezésünkre álló eszköztárat.

Hasonlóan a strukturális csődmodellezéshez, az intenzitás alapú modellek célja is olyan értékpapírok és követelések árazása volt, amelyeknél nemfizetési kockázat állt fent. Mivel azonban a dolgozat további fejezeteinek a megértéséhez elegendő a fentebb adott bevezetés, így a téma további részleteit nem ismertetem, hanem egy rövid áttekintést adok a szakirodalom fontos mérföldköveirôl.

A redukált formájú csődmodellezés irodalma is több évtizedre nyúlik vissza. Az elsók között Pye (1974) rövid munkáját szokás említeni, azonban a mai formában is használatos formalizáció csak késóbb Jarrow és Turnbull (1995) munkájával 
jelent meg. Jarrow és Turnbull (1995) csődkockázatnak kitett diszkont kötvény árazását végzik el. Késóbb ezt a munkát Jarrow et al. (1997) bôvítik hitelminôsítési kategóriák és azok közötti migráció figyelembevételével. A következő mérföldkő Lando (1998) munkája, aki bevezeti az általunk is leírt Cox folyamatot a csődmodellezésre. A Lando (1998) által adott formalizmus szerint a csôdesemény szimulálása az alábbi feladat megoldását jelenti:

$$
\tau=\inf \left\{t: \int_{0}^{t} \lambda(s) d s \geq \mathcal{E}\right\}
$$

amely megegyezik a fentebb adott eljárással.

A részletekért érdeklődő Olvasónak a korai munkákból Duffie és Singleton (1999), Duffie és Singleton (1997), vagy Collin-Dufresne és Solnik (2001) tanulmányait ajánlom, vagy Schönbucher (2003), Lando (2009) és Bielecki és Rutkowski (2013) a témával foglalkozó remek könyveit. A fentebbi korai munkák olyan kockázatos termékek árazásával foglalkoztak, ahol az adós és a hitelezô szerepe jól elkülönül. A nemteljesítési kockázatnak kitett kétoldalú követelések árazására a hitelértékelési kiigazítás bemutatásánál visszatérek.

Ennél a pontnál érdemes összehasonlítani az intenzitás alapú és a korábban leírt strukturális modelleket. Egyrészt szemben a diffúziós folyamatra épülő strukturális modellekkel a csődidôpont elveszti az előrejelezhetôségét, amely növeli a modell realitását. A fenti formalizálásból azonban világos, hogy miközben az intenzitás folyamat kiemelt szerepet nyer, addig a vállalat értéke eltúnik a modellból. Az intenzitás alapú modellezés egyik kritikájának ezt a hiányosságát szokták megnevezni. Valójában az intenzitás folyamatot rugalmasan kalibrálhatjuk az éppen aktuális piaci feltételekhez, amely lehetôséget ad a vállalat állapotát tükröző, piacon megfigyelhető értékek modellbe történô beolvasztására.

A piaci gyakorlatban szokás egy egyszerúsített eljárás alapján összekötni a vállalat CDS felárát és az intenzitás folyamatot. A CDS felár az az érték, amelyet a biztosított fél köteles fizetni a referencia értékpapír cső́deseményéig. Ezt a biztosítási prémiumot a piacon több lejáratra is jegyzik. ${ }^{15}$ Az egyszerúsített formula szerint:

$$
\lambda(T)=\frac{s(T)}{L G D},
$$

ahol $s(T)$ jelenti a $T$ lejáratra jegyzet CDS felárat. A formula intuitív megértéséhez emlékezzünk vissza, hogy a $\lambda d t$ az azonnali csődvalószínúséget jelentette, míg annak $L G D$-vel vett szorzata a várható veszteséget adta eredményül. A hitelmulasztási ügyleten fizetett biztosítási díj ( $s d t$ ) éppen ezzel kell, hogy egyenlő

${ }^{15}$ Itt feltételeztem, hogy a szóban forgó CDS ügyletnek létezik likvid piaca. Ez nem minden esetben áll fenn. Ilyenkor közelítéseket szokás használni a nem megfigyelhetô felár becslésére, amelyek a leggyakrabban hitelminôsítés, régió és iparág alapján egy kategóriába esó vállalatokat felárait használják. 
legyen ${ }^{16}$ Ezzel a módszerrel szakaszosan konstans intenzitás paramétert becsülhetünk. A pontos kalibráció érdekében a CDS árazó formulából kell egy bootstrap jellegú eljárással kinyerni az intenzitás paraméter értékét, vagy az azt meghatározó sztochasztikus folyamat paramétereit. Így determinisztikus intenzitás folyamatokra O’Kane (2011), míg például CIR folyamaton alapuló becslésre Brigo és Alfonsi (2005) munkája ad részletes leírást.

A csődmodellek egy speciális elemzésére a 3. fejezetben térek vissza. Már a fentebbi rövid bevezetés után is felmerülhet a kérdés, hogy lehet-e egy vállalat csődeseményét társaiétól függetlenül kezelni. A redukált formájú modellekbe a korreláció többféleképpen is bevezethetô, amely befolyásolja a partnerkockázat árát is. A 3. fejezetben ennél egy lépéssel továbbmegyek, és egy modellt fejlesztve vizsgálom meg a hitelminősítések változásakor fellépő fertôző hatásokat.

A csődmodellek legfontosabb fogalmainak ismertetésével eljutottunk ahhoz a ponthoz, amikor bevezethetjük a hitelértékelési kiigazítást. Így most ezzel folytatjuk.

\subsection{A hitelértékelési kiigazítás}

Ezt a fejezetet a hitelértékelési kiigazítás technikai bemutatásával indítom, és majd a következô részben térek vissza a lehetséges értelmezési alternatívákra. Az analitikus megközelítésmód bemutatása során a szakirodalomban elterjedt leggyakoribb formalizálást ismertetem. Ebben többnyire Brigo et al. (2013) munkáját követem, de számos esetben eltérek attól. A szakirodalom részletes ismertetését a következô fejezetben végzem el. Ennek oka, hogy véleményem szerint könnyebb megérteni azt, hogy az egyes korábbi tanulmányok mivel is járultak hozzá a hitelértékelési kiigazítás lentebbi alakjához, ha már ismerjük a teljes elméleti keretrendszert. Kezdjük tehát a hitelértékelési kiigazítás ismertetésével és szorítkozzunk rögtön egy egyszerúbb esetre, amellyel az egyoldalú hitelértékelési kiigazítás definíciójához juthatunk el. Továbbá, ebben a fejezetben feltételezem, hogy egy olyan derivatív szerzôdés kerül elemzésre, ahol a felek között nincs letéti egyezmény. A következô részben bemutatom e feltételek általánosításának következményeit.

A derivatív szerződés pénzáramainak $\Pi(t, T)$ definíciójában kihasználtam, hogy a szerződő felek kockázatmentesek. A diszkontált pénzáramok összege azonban egészen máshogy néz ki, ha ezt a feltételezést elvetem. Először az egyszerúség kedvéért tegyük fel, hogy az egyik fél a szerződés élettartama alatt csődölhet, miközben a másik fél továbbra is kockázatmentes. ${ }^{17} \mathrm{Az}$ új partnerek között létrejött

${ }^{16}$ A formula formális levezetése megtalálható Brigo et al. (2013) munkájában.

${ }^{17}$ Késôbb látni fogjuk, hogy mindkét fél kockázatmentességének elvetése komolyabb problémákhoz vezet. 
derivatív szerződés pénzáramainak diszkontált összegére a $\overline{\Pi(t, T)}$ jelölést használom. A kockázattal kiigazított pénzáram előáll a kockázatmentes pénzáram és a csődesemény esetén történő kifizetés az alábbiakban adott kombinációja szerint: $\overline{\Pi(t, T)}=1_{(\tau>T)} \Pi(t, T)+1_{(t<\tau \leq T)}\left[\Pi(t, \tau)+D(t, \tau) R E C\left(V_{\tau}\right)^{+}-D(t, \tau)\left(-V_{\tau}\right)^{+}\right]$,

ahol $1_{(.)}$az indikátor folyamat, azaz általános esetben:

$$
1_{(a \in \mathcal{A})}= \begin{cases}1, & a \in \mathcal{A} \\ 0, & a \notin \mathcal{A} .\end{cases}
$$

Az 1.30, egyenlet szerint a $t$ és $T$ közötti, kockázattal kiigazított pénzáramok megegyeznek a kockázatmentes pénzáramokkal, feltéve, ha nincs csődesemény ezen az intervallumon. Ellenkezô esetben a kockázattal kiigazított pénzáramok $t$ időpontra diszkontált összege megegyezik a csődeseményt megelőző kockázatmentes pénzáramok diszkontált értékének, a csődeseménykor fennálló kitettségból megtérülő érték, valamint a fennálló kötelezettség értékének az összegével. A korábbi kitettség definíciók alapján az utolsó két tag közül csak az egyik lehet nem nulla.

A hitelértékelési kiigazítás a partnerkockázat mentes és a kockázatos származtatott termék ára közötti különbséget jelenti. Emiatt a hitelértékelési kiigazítást a partnerkockázat árának szokás hívni. Az 1.30. egyenlet felhasználásával kiszámolhatjuk ezt a különbséget, és megadhatjuk az egyoldalú hitelértékelési kiigazítás formális definícióját:

$$
\begin{aligned}
\mathbb{E}_{t}[\Pi(t, T)-\overline{\Pi(t, T)}]=\mathbb{E}_{t}\left[\Pi(t, T)-1_{(\tau>T)} \Pi(t, T)\right. \\
\left.\quad-1_{(t<\tau \leq T)}\left[\Pi(t, \tau)+D(t, \tau) R E C\left(V_{\tau}\right)^{+}-D(t, \tau)\left(-V_{\tau}\right)^{+}\right]\right] \\
=\mathbb{E}_{t}\left[1_{(\tau>T)} \Pi(t, T)+1_{(t<\tau \leq T)} \Pi(t, T)-1_{(\tau>T)} \Pi(t, T)-1_{(t<\tau \leq T)} \Pi(t, \tau)\right. \\
=\mathbb{E}_{t}\left[1_{(t<\tau \leq T)} D(t, \tau)\left(\Pi(\tau, T)-R E C\left(V_{\tau}\right)^{+}+\left(-V_{\tau}\right)^{+}\right)\right] \\
=\mathbb{E}_{t}\left[\mathbb{E}_{\tau}\left[1_{(t<\tau \leq T)} D(t, \tau)\left(\Pi(\tau, T)-R E C\left(V_{\tau}\right)^{+}+\left(-V_{\tau}\right)^{+}\right)\right]\right] \\
=\mathbb{E}_{t}\left[1_{(t<\tau \leq T)} D(t, \tau)\left[V_{\tau}-R E C\left(V_{\tau}\right)^{+}+\left(-V_{\tau}\right)^{+}\right]\right] \\
=\mathbb{E}_{t}\left[1_{(t<\tau \leq T)} D(t, \tau)(1-R E C)\left(V_{\tau}\right)^{+}\right]
\end{aligned}
$$

A fenti átalakítás sorozat második egyenletében kihasználtam, hogy $\Pi(t, T)=$ $=1_{(\tau>T)} \Pi(t, T)+1_{(t<\tau \leq T)} \Pi(t, T)$, majd a feltételes várhatóértékre vonatkozó to- 
ronyszabályt alkalmaztam és végül a $V_{t}=V_{t}^{+}-\left(-V_{t}\right)^{+}$azonossággal egyszerúsítettem. Így a kockázattal kiigazított árat felírhatjuk a kockázatmentes és a fenti képletból kapott tag különbségeként:

$$
\mathbb{E}_{t}[\overline{\Pi(t, T)}]=\mathbb{E}_{t}[\Pi(t, T)]-\mathbb{E}_{t}\left[L G D 1_{(t<\tau \leq T)} D(t, \tau)\left(V_{\tau}\right)^{+}\right]
$$

Így a korábban adott definíciót formálisan is felírhatjuk, azaz a $t$ idôpontban számolt egyoldalú hitelértékelési kiigazítás a következő formában adható meg:

$$
C V A_{t}=\mathbb{E}_{t}\left[L G D 1_{(t<\tau \leq T)} D(t, \tau)\left(V_{\tau}\right)^{+}\right]
$$

$\mathrm{Az}$ 1.34. egyenletben egy komplex feltételes várható érték formulát kaptunk, amelyben megjelenik számos sztochasztikus folyamat, mint például a csődindikátor vagy a kitettség folyamatai. Ugyan a fenti formula egy zárt alak, de annak szemi-analitikus jellege miatt a $C V A_{t}$ meghatározásához specifikálni kell az egyenletben szereplő egyes mennyiségeket. Az 1.34. egyenlet egy egyszerú közelítését adhatjuk meg, ha a lejáratig hátralévô időtartamot diszkretizáljuk. Mivel egy $t=t_{0}<t_{1}<\ldots<t_{m}=T$ tetszóleges felosztásra teljesül, hogy

$$
1_{(t<\tau \leq T)}=\sum_{i=1}^{m} 1_{\left(t_{i-1}<\tau \leq t_{i}\right)},
$$

ezért

$$
C V A_{t}=\sum_{i=1}^{m} \mathbb{E}_{t}\left[L G D 1_{\left(t_{i-1}<\tau \leq t_{i}\right)} D(t, \tau)\left(V_{\tau}\right)^{+}\right] .
$$

Amennyiben a közelítéshez csődidőpontban fennálló kitettséget az intervallum végi értékkel közelítjük, akkor az egyoldalú hitelértékelési kiigazítás gyakorlatban használt diszkretizált alakját kapjuk:

$$
C V A_{t} \approx \sum_{i=1}^{m} \mathbb{E}_{t}\left[L G D 1_{\left(t_{i-1}<\tau \leq t_{i}\right)} D\left(t, t_{i}\right)\left(V_{t_{i}}\right)^{+}\right] .
$$

A konstans $L G D$ feltételezése miatt két faktorra bontható a várható értéken belüli kifejezést: A csődindikátorra $\left(1_{\left(t_{i-1} \leq \tau \leq t_{i}\right)}\right)$ és a diszkontált, nemteljesítéskori kitettség értékére $\left(D\left(t, t_{i}\right)\left(V_{t_{i}}\right)^{+}\right)$. Amennyiben ez a két sztochasztikus folyamat független egymástól, akkor a várhatóértéket külön-külön alkalmazhatjuk az egyes tényezőkre. Írjuk fel az így kapott alakot egyszerúsített $t=t_{0}=0$ esetre:

$$
C V A=\sum_{i=1}^{m} L G D \mathbb{Q}\left(t_{i-1}<\tau \leq t_{i}\right) \mathbb{E}\left[D\left(0, t_{i}\right)\left(V_{t_{i}}\right)^{+}\right]
$$

Ebból az egyszerú formulából számos következtetést levonhatunk. Elôször is a korábban bemutatott egyik legfontosabb kitettség mérőszámot, a diszkontált kitettség profilt közvetlenül felhasználhatjuk a hitelértékelési kiigazítás számításakor. 
Másodszor, a fenti egyszerú esetben csupán a derivatív értékének meghatározásához szükséges modellre van szükség, hiszen a csốdvalószínûségek a piacról megfigyelhetőek. Ahogy majd látni fogjuk egy általánosabb modellben ez nem így van, ezért a csôdesemény modellezése is fontos feladatot kap. Végül vegyük észre, hogy a hitelértékelési kiigazítás értéke nem független a használt modelltól. A kitettség profil változhat a felhasznált modell függvényében, amely érelemszerúen befolyásolja a hitelértékelési kiigazítást is. Így például az árazás bonyolult feladattá válik egy olyan egyszerú termék esetén is, amely nem függ a piaci faktorok volatilitásától vagy korrelációjától. Ebben az esetben ugyanis e paraméterek befolyásolják a kitettség profilt, vagy általánosabb keretekben a csődvalószínúségeket. A hitelértékelési kiigazítás tehát a komplexitáson túl jelentôs modell kockázatot is magában hordoz.

A valóságban azonban sokszor nem tételezhetjük fel a kitettség és a csődindikátor függetlenségét. A kapcsolatuk irányától függốen beszélhetünk rossz és jó irányú kockázatról. Amikor a kitettség értéke jellemzôen nô a partner csôdvalószínúségével együtt, akkor rosszirányú kockázatról beszélünk, ilyenkor ugyanis a csőd pillanatában rendszerint nagyobb kitettségünk lesz, mint a független esetben. A jó irányú kockázat a fenti ellentéte és az esetek többségében kockázatkezelési szempontból kevésbé aggasztó. Az 1.37 alapján megadhatunk egy általánosabb CVA definíciót, amely nem támaszkodik a függetlenségi feltevésre:

$$
\begin{aligned}
C V A=\sum_{i=1}^{m} \mathbb{E}\left[L G D 1_{\left(t_{i-1}<\tau \leq t_{i}\right)} D\left(0, t_{i}\right)\left(V_{t_{i}}\right)^{+}\right] \\
\quad=\sum_{i=1}^{m} L G D \mathbb{Q}\left(t_{i-1}<\tau \leq t_{i}\right) \mathbb{E}\left[D\left(0, t_{i}\right)\left(V_{t_{i}}\right)^{+} \mid t_{i-1}<\tau \leq t_{i}\right]
\end{aligned}
$$

ahol ismét felhasználtuk, hogy az $L G D$ konstans. A fő különbség az 1.37. és az 1.39. egyenlet között, hogy a diszkontált kitettség csődidőpontra feltételes várható értéke váltja fel a feltétel nélküli profilt. Hamarosan részletezem a számításhoz használt numerikus eljárásokat, de azt már most láthatjuk, hogy a fenti kapcsolat miatt már nem lehet függetlenül kitettség profilt és csődvalószínûségeket számolni.

A teljesség kedvéért megadok egy, a szakirodalomban gyakran előforduló másik alakot (Brigo és Masetti (2005), Vrins (2017)), ami az 1.34. egyenlet diszkretizálás nélküli átalakítása azzal a feltételezéssel, hogy a csődidôpont eloszlásfügg- 
vénye ismert. Ha ugyanis $G(t)=\mathbb{Q}(\tau>t)$ differenciálható, akkor

$$
\begin{aligned}
C V A=\mathbb{E}\left[L G D 1_{(\tau \leq T)} D(0, \tau)\left(V_{\tau}\right)^{+}\right] \\
=L G D \int_{0}^{T} \mathbb{E}\left[D(0, t)\left(V_{t}\right)^{+} \mid \tau=t\right] d \mathbb{Q}(\tau \leq t) \\
\quad=-L G D \int_{0}^{T} \mathbb{E}\left[D(0, t)\left(V_{t}\right)^{+} \mid \tau=t\right] d G(t) .
\end{aligned}
$$

A fenti alak valóban hasonlóságot mutat az idődiszkretizált esetben bemutatott 1.39, formulával. Ennél azonban még tovább léphetünk, ha ismert az eloszlás konkrét formája. Így például emlékezzünk vissza a determinisztikus intenzitásfolyamattal ellátott redukált formájú csődmodellre, ahol a túlélési valószínúséget az alábbi formában adtuk meg:

$$
G(t)=\mathbb{Q}(\tau>t)=e^{-\int_{0}^{t} \lambda(s) d s}
$$

ebben az esetben a $\tau$ sưrúségfüggvénye $g(t)$ előáll, mint

$$
g(t)=\frac{d(1-G(t))}{d t}=\lambda(t) G(t)
$$

amelyből

$$
\begin{aligned}
C V A=-L G D \int_{0}^{T} \mathbb{E}\left[D(0, t)\left(V_{t}\right)^{+} \mid \tau=t\right] d G(t) \\
=L G D \int_{0}^{T} \mathbb{E}\left[D(0, t)\left(V_{t}\right)^{+} \mid \tau=t\right] g(t) d t
\end{aligned}
$$

Az általánosabb esetekben, ahol $\mathbb{Q}(\tau>t) \neq \mathbb{Q}\left(\tau>t \mid \mathcal{F}_{t}\right)$ - például a Cox folyamat esetében - Vrins (2017) tanulmányát követve megadhatjuk az alábbi formát is:

$$
C V A=\mathbb{E}\left[L G D 1_{(\tau \leq T)} D(0, \tau)\left(V_{\tau}\right)^{+}\right]=L G D \mathbb{E}\left[\int_{0}^{T} D(0, t)\left(V_{t}\right)^{+} d S P_{t}\right]
$$

ahol $S P_{t}=\mathbb{Q}\left(\tau>t \mid \mathcal{F}_{t}\right)$, de a kalibrációs egyenlet szerint $\mathbb{E}\left[S P_{t}\right]=\mathbb{Q}(\tau>t)$.

A fentebb bemutatott kiigazítás tehát csökkenti a kockázatmentes árat, hiszen a kockázatmentes fél figyelembe veszi társa lehetséges nemteljesítését. Ugyanakkor azonban a kockázatos fél is egy kiigazított árat fog látni. Ha ugyanis feltételezzük, hogy a két fél megegyezik az árban, akkor azok ellentétes elójellel, de abszolút értékben ugyanazt az értéket használják. Azaz, ha $\bar{V}_{t}^{B}$ és $\bar{V}_{t}^{C}$ jelöli a B és C között megkötött származtatott termék C partnerkockázatával kiigazított árát B és C szemszögéból, akkor:

$$
\bar{V}_{t}^{B}=-\bar{V}_{t}^{C} .
$$

De az 1.33. egyenlet alapján tudjuk, hogy

$$
\bar{V}_{t}^{B}=V_{t}^{B}-C V A_{t}^{B} .
$$


A korábbi érvelésre alapozva most tegyük fel, hogy $\mathrm{C}$ szemszögéból az ár a következőképpen áll elô:

$$
\bar{V}_{t}^{C}=V_{t}^{C}+D V A_{t}^{C},
$$

ahol $D V A_{t}^{C}$ jelenti a $\mathrm{C}$ szemszögéból számolt árkiigazítást. Az 1.45 1.47. egyenletek és $V_{t}^{B}=-V_{t}^{C}$ alapján világos, hogy:

$$
-C V A_{t}^{B}=-D V A_{t}^{C}
$$

Így az egyik fél nemteljesítési kockázata befolyásolni fogja az általa megfigyelt árat. Az ô szemszögéból mért kiigazítás mértéke pedig nem lesz más, mint a korábban leírt egyoldalú kiigazítás ellentéte. Ezt a mennyiséget a szakirodalom kötelezettségértékelési kiigazításnak (DVA) ${ }^{18}$ nevezi, és az alábbiak szerint formalizálható :

$$
\begin{aligned}
D V A^{C}=C V A^{B}=\mathbb{E}\left[L G D 1_{(0<\tau \leq T)} D(0, \tau)\left(V_{\tau}^{B}\right)^{+}\right] \\
=\mathbb{E}\left[L G D 1_{(0<\tau \leq T)} D(0, \tau)\left(-V_{\tau}^{C}\right)^{+}\right]
\end{aligned}
$$

ahol felhasználtuk a csôdeseménykor fennálló kitettség értékét, de most a nemteljesítő fél szempontjából. A fenti definícióhoz a pénzáramok részletes felírásával is eljuthattunk volna. Ez a gyakorlat analóg azzal, amit a fejezet elején elvégeztünk, így itt most nem ismétlem meg.

A kötelezettségértékelési kiigazítás definíció szerint pozitív, így amikor hozzáadjuk az árhoz az eredeti árnál magasabbat kapunk. De miért is ér többet a kockázattal kiigazított ár a kockázatmentesnél, amikor a partner is kockázatmentes? Ennek a megértéséhez a nemteljesítéskori pozíciózárás szabályaira kell visszaemlékeznünk, ahol is két esetet különböztettünk meg. A csődeseménykor vagy a túlélő fél tartozik, így az teljesíti kötelezettségét, míg alternatív esetben veszteséget szenved el a követelésén. A nemteljesítő fél szempontjából ez egy nyereség, hiszen ilyenkor csupán a valós kötelezettségének egy részét teljesíti. Ez az opció, ami számára értéket teremt, és ami miatt a derivatív értéke nő.

A kockázatmentes fél tehát veszteséget tud elszenvedni abban az esetben is, amikor a kockázatmentes ár változatlan marad, de a partner hitelminősége romlik, amely növeli a hitelértékelési kiigazítást. Ez az elsőre teljesen természetes lehetôség, azonban érdekes következményekkel jár, ha a másik fél szemszögéból vizsgáljuk azt. Ekkor ugyanis a partner minden más változatlansága mellett pusztán a hitelminősége romlásával nyereséget könyvelt el. Elsôsorban ez a viselkedés járult ahhoz, hogy számos korai munka kritizálta a DVA számítását. ${ }^{19}$

18 A DVA az angol „Debit Valuation Adjustment” kifejezés rövidítése.

${ }^{19}$ A vita legfontosabb mérföldköveinek Burgard és Kajaer (2010), Burgard és Kjaer (2011), Carver (2011) és Castagna (2012) tanulmányai számítanak. 
A legfontosabb érv a saját nemteljesítési kockázat figyelembevétele ellen az volt, hogy a kötelezettségértékelési kiigazítás által megtestesített jövóbeli nyereség értékét a kockázatos fél sohasem tudja realizálni, hiszen akkorra az már csődbe ment. A kritikus cikkek egyik másik problémája a DVA fedezésének a kérdése volt. A fedezés ugyanis szükséges az árazáshoz, de ennek lehetôségét vonja kétségbe Gregory (2009), hiszen senki nem kötne hitelmulasztási ügyletet egy vállalattal, ahol a referencia név maga a vállalat. A fedezés részben megoldható proxy fedezéssel, ahol a vállalat saját hitelminőségével erôsen korreláló vállalatokra ad el hitelmulasztási ügyletet, de világos, hogy ez számos kockázatot köztük az egyedi hatásokat és a váratlan csődeseményt figyelmen kívül hagyja.

A szakirodalomban megfogalmazott kritikákat és az azokra adott válaszokat ma a DVA vita néven emlegetik. Ez a vita a DVA elfogadásával zárult, amelynek legfóbb okai az alábbi érvek voltak. Ugyan a csőd után a partner valóban nem képes nyereségként realizálni a lecsökkentett tartozását, de Sokol (2010) kiemeli, hogy valójában azt még a csődesemény előtt képes megtenni. Sokol (2010) alapján ugyanis könnyen elképzelhetünk olyan csőd szélén álló vállalatot, amely partnere hajlandó lenne diszkont áron zárni a pozíciót annak érdekében, hogy elkerülje a csőd miatti nagyobb veszteséget. Így tehát a kétoldalú DVA-ból adódó nyereség igenis realizálható.

A nemzetközi számviteli szabályok alkotói, mint például a Financial Acounting Standards Board (FASB), vagy az International Accounting Standards Board (IASB) is a DVA mellett tették le a voksukat. Mind a Financial Accounting Standard 157 (FAS 157), mind pedig az International Accounting Standards 39 (IAS 39) kiemeli, hogy a derivatív valós értékének (fair value) meghatározásakor a számítást végzô félnek a saját nemteljesítési kockázatának a hatását is figyelembe kell vennie. Az ezeket 2013. január 1-jén leváltó International Financial Reporting Standards 13 (IFRS 13) szabályozás sem változtatott a partnerkockázat kezelésén: mind a CVA és mind a DVA részei az árnak 20

Természetesen egyszerúbb érveket is lehet hozni a DVA elfogadhatóságára. $\mathrm{Az} 1.49$. egyenlet alapján láthatjuk, hogy a partner DVA-ja megegyezik a másik fél hitelértékelési kiigazításával. Márpedig, ha a CVA tagot elfogadjuk, akkor azzal követve a DVA taggal is ezt tesszük (Brigo et al., 2013). Nem mellesleg, ha a DVA tag nem jelenne meg a partner oldalán számított árban, akkor a felek aszimmetrikus árat látnának, amely mellett nem tudnának egyezséget kötni.

Az idő is a kötelezettségértékelési kiigazítást igazolta, hiszen a bankok fokozatosan bevezették azt a mindennapi ügyleteikbe, és hivatalos kimutatásaikba. Így a DVA vitát kiváltó viselkedés, miszerint a partner hitelminôségének rom-

${ }^{20}$ A különbözó számviteli rezsimek közötti összehasonlításához az alábbi tanulmányt javasoljuk: http://www.solum-financial.com/wp-content/uploads/2014/09/ Solum-Monthly-Insights-May-2013-Credit-Risk-Accounting-under-IFRS13.pdf 
lásakor nyereséget ér el a pozícióin, a tankönyvi példákból valós esetekké nôtte ki magát. Brigo et al. (2013) feljegyzései alapján a 2011-es harmadik negyedév eredményeiben a Goldman Sachs 450, a J.P. Morgan 1500, a Bank of America 1700, a Citigroup 1500 millió dollár DVA nyereséget könyveltek el.

Mielőtt továbblépek meg kell jegyezni, hogy a tőketartalékolási szabályokban is megjelenik a partnerkockázati kiigazítás, azonban ezekben az esetekben csupán a hitelértékelési kiigazítást engedélyezik. Így a DVA nem része a tőketartalékolási módszereknek. Ezekkel még a késóbbiekben részletesen fogok foglalkozni.

Az egyoldalú hitelértékelési kiigazítás számításakor azt feltételezzük, hogy az egyik fél kockázatmentes, azaz minden esetben teljesíteni fogja a kötelezettségeit. Ez a feltételezés még olyan esetekben is erôs, ahol a felek között jelentős hitelminőség különbség áll fenn. A kockázatmentes partner fogalma végül a Lehman Brothers csődje után teljesen eltûnt a piaci gyakorlatból. Ezért a korábban bevezetett megközelítésmódot is át kell alakítani.

Amennyiben feltételezzük, hogy mindkét fél kockázatos, akkor meg kell különböztetnünk azok csődeseményeit. B és $\mathrm{C}$ vállalatok esetében jelölje $\tau_{B}$ és $\tau_{C}$ azok csődidôpontjait, valamint $L G D_{B}$ és $L G D_{C}$ a nemteljesítéskori veszteségrátáikat. A korábbiak alapján gondolhatnánk, hogy a mindkét fél kockázatát magába foglaló árat könnyen felírhatjuk az alábbiak szerint:

$$
\bar{V}_{t}^{B}=V_{t}^{B}+D V A_{t}^{B}-C V A_{t}^{B},
$$

ahol

$$
C V A_{t}^{B}=\mathbb{E}_{t}\left[L G D_{C} 1_{\left(t<\tau_{C} \leq T\right)} D\left(t, \tau_{C}\right)\left(V_{\tau}^{B}\right)^{+}\right]
$$

és

$$
D V A_{t}^{B}=\mathbb{E}\left[L G D_{B} 1_{\left(t<\tau_{B} \leq T\right)} D\left(t, \tau_{B}\right)\left(-V_{\tau}^{B}\right)^{+}\right] .
$$

Fenti formula egy egyszerú megoldást adna a kockázatos partnerek esetére. Ugyan már az egyoldalú hitelértékelési kiigazítás is komplex számításokhoz vezetett, de legalább az azokhoz felhasznált mennyiségeket újra fel tudnánk használni a kétoldalú kiigazítás számításához. Sajnos az 1.50. egyenlet pontatlan, ami miatt azt nem használhatjuk. Brigo et al. (2012) hívták fel a figyelmet arra, hogy fenti forma figyelmen kívül hagyja a csődidőpontok kapcsolatát, és így többször veheti figyelembe azokat a szcenáriókat, ahol mindkét partner csôdeseménye bekövetkezik a derivatív lejáratáig, holott akkor már az elsô csődeseménynél zárják a derivatívát. Ugyan a fenti forma korai, vagy egyszerûsített számítások esetében előfordul, de a valódi kétoldalú hitelértékelési kiigazításhoz ismét a pénzáramok felírásával juthatunk el. Jelentse $\tau$ az elsô csődeseményt, azaz $\tau=\min \left\{\tau_{B}, \tau_{C}\right\}$. A dolgozat során feltételezem, hogy a partnerek csődidôpontjai nem eshetnek egybe. Ettől eltérô feltételezéssel megfogalmazott kétoldalú kiigazításhoz Gregory (2009) 
munkáját javaslom. Most írjuk fel a kockázattal kiigazított pénzáramokat:

$$
\begin{aligned}
\overline{\Pi(t, T)} & =1_{(\tau>T)} \Pi(t, T) \\
& +1_{\left(t<\tau=\tau_{C} \leq T\right)}\left[\Pi\left(t, \tau_{C}\right)+D\left(t, \tau_{C}\right) R E C_{C}\left(V_{\tau_{C}}\right)^{+}-D\left(t, \tau_{C}\right)\left(-V_{\tau_{C}}\right)^{+}\right] \\
& +1_{\left(t<\tau=\tau_{B} \leq T\right)}\left[\Pi\left(t, \tau_{B}\right)+D\left(t, \tau_{B}\right)\left(V_{\tau_{B}}\right)^{+}-D\left(t, \tau_{B}\right) R E C_{B}\left(-V_{\tau_{B}}\right)^{+}\right],
\end{aligned}
$$

ahol a jelölések egyszerúsítése miatt nem írtam ki, de feltételezem, hogy minden pénzáram és ár B szemszögéból van számolva. Hasonlóan az egyoldalú esethez itt is figyelembe kell vennünk a csődesemény által okozott változásokat a pénzáramokban. Az elsố csôdidôpontig a pénzáramok megegyeznek a kockázatmentes pénzáramokkal, viszont azután a lehetséges kifizetések azon múlnak, hogy melyik partner csôdeseménye következett be. Ha a nemteljesítô fél megegyezik a számítást végzô féllel, akkor figyelembe vesszük, hogy ô a teljes követelését megkapja $\left(D\left(t, \tau_{B}\right)\left(V_{\tau_{B}}\right)^{+}\right)$, de kötelezettségeinek csak töredékét fizeti ki $\left(-D\left(t, \tau_{B}\right) R E C_{B}(-\right.$ $\left.\left.-V_{\tau_{B}}\right)^{+}\right)$. Ellenkező esetben az egyoldalú kockázatnál már felírt kifizetéssel találkozunk. Fontos azonban, hogy ez csak akkor lesz számításba véve, ha a partner csődidôpontja megelôzi a számítást végzô fél csődidôpontját. A korábban bemutatott levezetéshez hasonlóan, ezeket a pénzáramokat is átalakíthatjuk, és felírhatjuk a kockázattal kiigazított árat. Ehhez Brigo és Capponi (2008) és Brigo et al. (2014) tanulmányára támaszkodhatunk.

$$
\begin{aligned}
& \mathbb{E}_{t}[\overline{\Pi(t, T)}]=\mathbb{E}_{t}[\Pi(t, T)]+\mathbb{E}_{t}\left[L G D_{B} 1_{\left(t<\tau=\tau_{B} \leq T\right)} D\left(t, \tau_{B}\right)\left(-V_{\tau_{B}}\right)^{+}\right] \\
& \quad-\mathbb{E}_{t}\left[L G D_{C} 1_{\left(t<\tau=\tau_{C} \leq T\right)} D\left(t, \tau_{C}\right)\left(V_{\tau_{C}}\right)^{+}\right]=\mathbb{E}_{t}[\Pi(t, T)]+b D V A_{t}^{B}-b C V A_{t}^{B}
\end{aligned}
$$

Ha összehasonlítjuk az 1.54. és az 1.50. egyenleteket, akkor láthatjuk a köztük fennálló hasonlóságot, de a csôdindikátor folyamatban látható egyetlen eltérés már elég ahhoz, hogy a csôdidôpontok kapcsolata megjelenjen a javított egyenletben. Természetesen ez az aprónak tûnő változtatás jelentős nehézségeket okoz a modellezéskor, ami miatt ilyen esetekben már elkerülhetetlen a csődesemény modellezése.

Az 1.54. egyenletben adott mennyiséget nevezzük a kétoldalú kockázattal kiigazított árnak, amiból egyszerúen definiálhatjuk a kétoldalú hitelértékelési kiigazítást:

$$
\begin{aligned}
B C V A_{t}^{B}=b D V A_{t}^{B}-b C V A_{t}^{B}= & \mathbb{E}_{t}\left[L G D_{B} 1_{\left(t<\tau=\tau_{B} \leq T\right)} D\left(t, \tau_{B}\right)\left(-V_{\tau_{B}}\right)^{+}\right] \\
& -\mathbb{E}_{t}\left[L G D_{C} 1_{\left(t<\tau=\tau_{C} \leq T\right)} D\left(t, \tau_{C}\right)\left(V_{\tau_{C}}\right)^{+}\right]
\end{aligned}
$$

A kétoldalú hitelértékelési kiigazítás magában hordozza a DVA bevezetésénél már említett jelenségeket. Így például megtörténhet (sôt az esetek többségében megtörténik), hogy két kockázatos partner által megkötött ügylet többet ér, mint egy 
kockázatmentes felek között fennálló megállapodás. Ez valóban váratlanul hathat, de a DVA bevezetésénél, már leírtak után nem szabad meglepôdünk. Egyrészt az értékelés mindig nézôpont kérdése, hiszen a rosszabb minőségú partner számára a korábban már leírt opció miatt valóban többet ér a szerződés. Ezenfelül, a kétoldalú kiigazítás egy általánosítása annak az esetnek, amikor csak az egyik partner kockázatos és ő nyer a fentebbi opció miatt.

A technikai leírás után most a hitelértékelési kiigazítás értelmezésével folytatjuk. Az alternatív értelmezési lehetőségek mellett bemutatom a téma legfontosabb, eddig nem ismertetett eredményeit is.

\subsubsection{A CVA értelmezése és alternatív megközelítései}

Andersen et al. (2017a) a hitelértékelési kiigazításra, mint az információ tömörítés egy módjára utalnak. Az egyoldalú CVA az EPE-hez hasonlóan várható pozitív kitettség profil egy számra történô tömörítése. E szemléletmód alapján a CVA a kitettség profilhoz rendel egy mennyiséget. Az ilyen jellegú információ tömörítésnek számos előnye is adódik, de nem felejthetjük el, hogy a kapott eredmény nem egyértelmú a kitettség profilok tekintetében, hiszen a hitelértékelési kiigazítás a partner csôdvalószínúségétôl és a nemteljesítéskori veszteségrátától is függ. Ezek figyelembevételével a hitelértékelési kiigazítás is jobban értelmezhetô.

Az egyoldalú hitelértékelési kiigazítás egyik természetes értelmezése az áron megjelenő diszkont tényező. Brigo et al. (2013) példáját követve, ha ugyanis egy kockázatmentes piaci szereplő választhat, hogy egy másik kockázatmentes féllel, vagy egy kockázatos partnerrel kössön ügyletet, akkor mindaddig a kockázatmenteset fogja választani, amíg a kockázatos féltôl nem kap kedvezményt.

Az egyoldalú kiigazítás 1.34. egyenletben adott definíciójából adódóan a fenti diszkont értéke pedig nem más, mint a származtatott termék lejárata alatt bekövetkezô csődeseményból származó várható veszteség. Nem szabad elfelejtenünk, hogy a várható érték a kockázatmentes mérték alatt számolódik. Így, ahogy azt például Rosen és Saunders (2012) is kiemelik, a hitelértékelési kiigazítás nem egy kockázati mérték, hanem egy ár. Ugyan azt már a definíció megadásakor kiemeltem, hogy a CVA tag a partnerkockázat árát jelenti, de most már az1.34. egyenlet alapján látható, hogy a CVA egy komplex derivatív szerződésnek az ára. Mint azt már korábban leírtam, minden származtatott termék megadható a kifizetés függvényeivel. A hitelértékelési kiigazítással beárazott szerződés egy olyan származtatott termék, amely a csődeseménykor a partner felé fennálló követelés egy részét fizeti ki. Ugyanez jelenik meg a kétoldalú kiigazítás definíciójában, azonban ekkor a derivatív egy fokkal komplexebb, hiszen a saját nemteljesítéskori pénzáramot is megjeleníti, valamint a csôdesemények sorrendje is befolyásolja a kifizetést. Összefoglalva, a hitelértékelési kiigazítás számítása egy bonyolult derivatív ára- 
zási probléma. Emiatt gyakran egy kissé leegyszerúsítve magát a hitelértékelési kiigazítást is egy derivatívának nevezik. ${ }^{21}$

Tehát a hitelértékelési kiigazítás nem más, mint az az érték, amelyet ki kell fizetnie a partnerkockázatát fedező félnek. Pontosabban, a fentebb megfogalmazott derivatívával ellentétes pénzáramokat generáló szerződés költsége. De vegyük észre, hogy az egyoldalú kiigazítás esetében ez a derivatíva hasonló egy egyszerú hitelmulasztási ügylethez. A hitelmulasztási ügylet esetében azonban a referencia név csődeseményekor egy előre rögzített névérték kerül kifizetésre, amelytől a tényleges veszteség jelentősen eltérhet. Ezért bevezethetünk olyan, az egyes ügyletekre szabott derivatívákat, amelyek figyelembe veszik a nemteljesítéskori kitettség értékét, és annak megfelelő kifizetést biztosítanak. Cesari et al. (2009) éppen ezeket az úgynevezett feltételes hitelmulasztási ügyleteket (CCDS) ${ }^{22}$ és a fedezési érvelést használják a hitelértékelési kiigazítás bevezetésekor. Brigo et al. (2013) azonban rámutatnak, hogy ezek a származtatott termékek soha nem váltak népszerúvé, ami két okra vezethető vissza. Egyrészt a derivatíva magas fokú testreszabottsága magas költségekkel és alacsony likviditással párosult. Másrészt, szintén az egyediségük miatt, ezek a derivatívák csakis OTC piacokon megkötött kétoldalú szerződés formájában létezhettek, ami azonban újra felveti a partnerkockázat problémáját. Hiszen az egyik partner kockázatát elcserélő vállalat az új partner nemteljesítésének teszi ki magát. Így a feltételes hitelmulasztási ügyletek inkább elméleti szempontból érdekesek, mintsem gyakorlati relevanciájuk miatt.

Mégis érdemes a CVA által számszerűsített derivatívát részletesebben megvizsgálni. Ugyan az 1.34, egyenletból is kiolvasható, de az 1.38, alak jobban illusztrálja az általunk bemutatni kívánt gondolatot. Láthatjuk, hogy a korábban leírt komplex derivatíva felbontható egyszerúbb tagok összegére. Mindegyik tagban megjelenik az eredeti származtatott termék diszkontált jövóbeli értékének pozitív részére vonatkozó várható érték. Ezek számszerüsítik az adott idôpontban bekövetkezố nemteljesítés miatti jövőbeli pénzáramok elvesztésének az értékét. Természetesen ha a jövôbeli pénzáramok a vállat számára negatív értéket képviselnek, akkor nincs veszteség. Ezeket a tagokat tehát úgy is fel lehet fogni, mint a jövôbeli pénzáramokra vonatkozó opciókat. Ha például az eredeti termék egy kamatláb csereügylet volt, akkor ezek jövóbeli idôpontokban induló kamatláb swaption-ök lesznek. Tehát a hitelértékelési kiigazítás szétesik egy többszörös opcióárazási problémára. Maga a CVA pedig nem lesz más, mint a jövőbeli opciók értékének a csôdvalószínúségekkel súlyozott összege. Ez az észrevétel, ugyan egy egyszerúsített formában, de már az egyik legelsô hitelértékelési kiigazítás problémájával foglalkozó tanulmányban is megjelent.

${ }^{21}$ Lásd például Hull és White (2012) munkáját.

${ }^{22}$ A CCDS rövidítés az angol „Conditional Credit Default Swap” elnevezésból származik. 
A témában Sorensen és Bollier (1994) munkáját szokás az egyik elsô eredményként feltüntetni. A szerzők felismerték a kamatláb csereügyletekben rejlő kétoldalú partnerkockázatot, és annak árazására a csereügylet fix lábának kiigazítását javasolták. Sorensen és Bollier (1994) a partnerkockázat opció jellegére hivatkozva egy opcióhoz hasonló árazási sémát javasoltak. Mindkét fél shortol egy opciót, ami a partnere csődjét reprezentálja, míg tart egy opciót, amely a saját csôdjét jeleníti meg. Sorensen és Bollier (1994) ezen opcióknak az árára úgy tekint, mint swaption-ök sorozatának csődvalószínúséggel súlyozott értékére, ahol a swpation-ök a csőd után elmaradó pénzáram értékét számszerúsítik. ${ }^{24}$ Hull és White (1995) munkája is különös szereppel bír a dolgozat szempontjából, hiszen a szerzők nagyon korán felismerve az OTC derivatívák csődkockázatát egy általános keretrendszert adnak ennek a kockázatnak az árba történő beépítésére. Hasonló problémával foglalkozik Duffie és Huang (1996) tanulmánya, akik már redukált formájú modellben végzik el a kockázatos partnerek között megkötött kamatláb csereügylet árazását. Fontos látnunk, hogy ekkor a figyelem középpontjában maga a kockázattal kiigazított ár állt, így a partnerkockázat ára külön nem jelent meg. Az elméleti alapokat tehát már korán lefektették, azonban azok gyakorlatba történô átültetése csakis a partnerkockázat-kezelés fontosságának felértékelődésével, a válság alatti években történt meg. Ekkor kezdtek megjelenni azok a tanulmányok, amelyek kifejezetten a hitelértékelési kiigazítás tulajdonságait vizsgálták, és végül formalizálták a bemutatott egyoldalú és kétoldalú keretrendszert.

Eddig nem emeltem ki, de most érdemes a két megközelítésmód aszimmetriáját elemezni. Egyrészt vegyük észre, hogy az egyik fél szemszögéból számolt egyoldalú CVA nem egyezik meg a másik fél által számított egyoldalú CVA ellentettjével, azaz

$$
C V A^{B} \neq-C V A^{C}
$$

Yi (2011) kiemeli, hogy az eltérés a két számítás során használt eltérô csőd feltételezések miatt adódik, hiszen a két esetben más fél játssza a kockázatmentes és a kockázatos szerepet. Emiatt a csôdvalószínû́ségek is eltérôek lesznek. Fontos azonban megértenünk, hogy az aszimmetriának más okai is vannak. Egyrészt az

${ }^{23}$ Érdekes megjegyzésük az alábbi: "A nemteljesítési kockázat elemzését körülvevô akadémiai és gyakorlati érdeklődés már nem új. [...] Egyelôre kevés historikus adat áll rendelkezésre a kamatláb csereügyleteken bekövetkező csődeseményekról. Mi azonban arra számítunk, hogy az idô múlásával a nemteljesítési kockázat árazásának igazodnia kell a csereügyletek piacát meghatározó kínálathoz és kereslethez, ahogy azt a kötvények piacán is tette. Ahogy alacsonyabb hitelminôsítésú kibocsátók magasabb kupont fizetnek, alacsonyabb hitelminôsítésû partnereknek magasabb (alacsonyabb) fix kamatot kell majd fizetniük (kapniuk) a csereügyleteiken." (Sorensen és Bollier, 1994, p. 23)

24 Sorensen és Bollier 1994) nem adja meg az általunk bemutatott árazási formulát, mert az egyszerúsítés kedvéért feltételezik, hogy a csődesemény csakis egy pillanatban történhet meg. 
egyik fél várható pozitív kitettség profilja sem feltétlen fog megegyezni a másik fél várható pozitív kitettség profiljával. Továbbá értelemszerûen eltérô $L G D$ feltételezés is hozzájárulhat aszimmetriához.

Tehát, amikor a két fél úgy próbál meg szerződni, hogy mindkettő magát tekinti kockázatmentesnek, akkor nem fognak tudni megegyezni egy egységes árban. A kétoldalú hitelértékelési kiigazítás áthidalja ezt a problémát. Ebben az esetben a két fél által számolt árkiigazítás egymás ellentettje lesz, így az ár szimmetriája is megmarad. A bemutatott formulák azonban nem minden esetben képesek a valóságban fennálló feltételeket replikálni, így a gyakorlatban történő teljes körú felhasználhatóság érdekében az 1.54. egyenlet számos aprólékos vizsgálaton és bơvítésen ment keresztül. Ezen tanulmányok jellemzően a válság utáni években születtek, amikor is a hitelértékelési kiigazítást jelentôs figyelem kísérte. Ezek közül most röviden ismertetünk néhány jelentősebb eredményt.

Az elôző részben bemutatott leírásban közvetlenül egy származtatott termék alapján írtam fel a legfontosabb formulákat. Így például hiányzott az adott partnerrel megkötött derivatívákra vonatkozó nettósítási megállapodás és letéti egyezség figyelembevétele, amelyek szignifikánsan megváltoztathatják a partner szinten számolt hitelértékelési kiigazítás értékét. Mivel mindkét módszer csökkenti a kitettség nagyságát, ezért a legtöbb esetben az árkiigazítás mértéke is jelentősen csökken, bár teljesen nem tûnik el. Brigo et al. (2011), Brigo et al. (2013a) és Brigo et al. (2014) egy az 1.55. egyenlethez hasonló általános hitelértékelési kiigazítás árazó formulát adnak a letéti megállapodással kiegészített származtatott termékek esetére. Legfontosabb eredményük, hogy a letét hatékonysága szignifikánsan romlik hitelderivatívák, így például hitelmulasztási ügyletek esetén. Yi (2011) tovább általánosítja a letét melletti CVA modelljét, és bevezeti a hiteleseményekhez kötött korai pozíciózárási egyezségeket. Rámutat, hogy ugyan a hiteleseményekhez kötött korai pozíciózárási megállapodások csökkenthetik az egyoldalú hitelértékelési kiigazítást, addig azok hatása a kétoldalú hitelértékelési kiigazításra akár növelő is lehet.

Természetesen több derivatíva esetén fontos felmérni, hogy a partnerrel megkötött egyes derivatív szerződéseknek mekkora a hozzájárulása a partnerhez tartozó hitelértékelési kiigazításhoz. A hitelértékelési kiigazítás ügylet szintú allokációjával Pykhtin és Rosen (2010) munkája foglalkozik. Mivel egy adott ügyfélhez tartozó CVA allokációja a kitettség profilok felosztásának a feladata, így Pykhtin és Rosen (2010) a kitettségek Euler allokációját végzik el mind fedezetlen és fedezett nettósítási csoportot feltételezve. Hasonló, de részleteiben eltérô probléma merül fel egy új ügylet megkötésekor. Kockázatkezelési szempontból különösen fontos az új ügylet tervezésekor annak a CVA-hoz történô hozzájárulása. Gregory (2010) az elsó problémát marginális CVA-nek hívja, és megjegyzi, hogy az 
így kapott értékékek lényegesen eltérhetnek a második, úgynevezett inkrementális CVA-tôl, amelyet az ügyletek nettósítási csoporthoz történő adásával kapunk. Az inkrementális módszer szemben a marginális társával ugyan képes új ügyletek partnerkockázatra gyakorolt hatásának mérésére, de az eredmény az ügyletek sorrendjétól függ.

A CVA allokációjának kérdése mellett felmerülhet a hitelértékelési kiigazítás alkalmazásának a szintje is. Szemben a bemutatott árkiigazítással, a diszkont megjelenhet a származtatott termék paraméterezésében is. Így például a hitelértékelési kiigazítás értékét tükrözheti egy kamatláb csereügylet fix lábán történő kiigazítás, ahogy Sorensen és Bollier (1994) is javasolták. Az árkiigazítás paraméterre történő transzformációjával foglalkozik Vrins és Gregory (2011) munkája, akik három lehetséges eljárást is adnak erre a problémára.

A pozíciózárás értelmezésének a problémájára mutatnak rá Brigo és Morini (2011). A kockázattal kiigazított pénzáramok felírásánál, implicite feltételeztem, hogy a pozíció zárása a kockázatmentes áron $\left(V_{\tau}\right)$ történik. Brigo és Morini (2011) kiemelik, hogy az ISDA keretszerződés lehetôséget ad arra, hogy a pozíciózáráskor a derivatív értékét az úgynevezett pótlási értéken vegyék számításba. A pótlási érték harmadik féltôl érkezô árajánlat a meglévô portfólióra, amely figyelembe veszi a túlélő fél kockázatát. Ennek értelmében az 1.54. egyenletben a kockázatmentes pénzáram helyett a DVA-val kiigazított árat kell használni. Azaz a kockázattal kiigazított ár meghatározása egy rekurzív problémává válik, amely jelentôs matematikai nehézségeket okoz. A dolgozat során eltekintek ettől a problémától, de az érdeklôdő Olvasónak Durand és Rutkowski (2013) vagy Gregory és German (2013) munkáit javasolom.

Végül egy fontos problémára szeretnék rámutatni. A technikai leírásban kiemeltem, hogy általános esetben figyelembe kell venni a kitettség és a csődesemények kapcsolatát. A kapcsolat irányától függően beszélhetünk rossz vagy jó irányú kockázatról. A rosszirányú kockázat különösen fontos témának számít, mivel az jellemzôen növeli a hitelértékelési kiigazítás értékét. A rosszirányú kockázat egyik szélsôséges példája, amikor egy vállalat eladási opciót vesz a partnere részvényeire. A részvények értékének a csökkenésével a vállalat kitettsége nô, de közben a partner pozíciója gyengül, így annak csődvalószínúsége nő. Hull és White (2012) rámutat, hogy a rosszirányú kockázat sokkal természetesebben is megjelenhet egy ügyletben. Ha egy vállalat jelentôs egyirányú pozíciót vesz fel, akkor a piaci faktorok ellentétes irányba történô változása esetén a vállalat fizetóképessége is meggyengül.

A rosszirányú kockázat Hull és White (2012) példájának gyakorlati jelentôségét jól mutatja az AIG válság előtti stratégiája. Mint az ismert, a válság alatt az AIG a csőd szélére került a korábban eladott óriási mértékú hitelmulasztási ügylet 
állománya miatt. A monoline biztosító kötelezettségei a rosszul teljesítő értékpapírosított termékek miatt fokozatosan nôttek, ami hozzájárult az AIG csôdvalószínúségének a növekedéséhez. Emiatt a hitelmulasztási ügyletek másik oldalán álló befektetôk kitettsége és a partnerük csődvalószínúsége egyszerre emelkedett.

A rosszirányú kockázat számszerúsítése azonban egy különösen nehéz feladat, mivel a csődvalószínûség és a kitettség közötti korrelációs paraméter nem becsülhetô. Éppen ezért gyakran csak arra vagyunk kíváncsiak, hogy szélsőséges korreláció mellett hogyan is változik a CVA értéke. Memartoluie et al. (2017) és Glasserman és Yang (2016) munkái ezzel a kérdéssel foglalkoznak. A két tanulmány egy családba sorolható abban a tekintetben, hogy adott marginális eloszlású alapfaktorok olyan közös eloszlását keresik, amely mellett valamely kockázati mérték maximális értéket vesz fel.

Rosen és Saunders (2012) munkája az úgynevezett rendezett szimulációs kopula modellben elemzi a rosszirányú kockázatot. A módszer újítása, hogy a függetlenül szimulált kitettség utak és a csődesemények sorba rendezésével ér el pozitív (vagy negatív) kapcsolatot a faktorok között.

Ghamami és Goldberg (2014) és Feng és Oosterlee (2017) rámutatnak, hogy bizonyos esetekben a hitelértékelési kiigazítás rosszirányú kockázat mellett csökken. Feng és Oosterlee (2017) a rosszirányú kockázat alternatív modelljeiben illusztrálja, hogy bermuda lehívási opcióval rendelkezô termékekre az optimális lehívási stratégia változik a kitettség és a csődvalószínúség korrelációja függvényében. Könnyen elképzelhető ugyanis, hogy az egyik fél hamarabb lehívja opcióját, ha a partnere csôdjétől tart. A korai lehívási opcióval azonban befolyásolhatja a kitettség alakját, így a CVA csökkenhet. Hasonló érvelést használ Vrins (2017) is, aki rosszirányú kockázat analitikusan kezelhetô eseteit vizsgálja.

Az eddig ismertetett szakirodalom alapján már érezhető, hogy a hitelértékelési kiigazítás kutatásának hazai közössége és a magyar nyelvú publikációk száma kicsi. A partnerkockázat Bázel III szabályozásával foglalkozik Pálosi-Németh (2012) tanulmánya, amiben a szerzô részletesen bemutatja a szabályozói CVA korábbi standardizált alakját. Pálosi-Németh (2015) tovább folytatja a szabályozói CVA bemutatását, de a hangsúlyt a partnerkockázat más területeire helyezi. Biedermann és Orosz (2015) a válság utáni szabályozások európai és amerikai implementációjában felmerülő különbségeket vizsgálják, amely során röviden kitérnek a szabályozói hitelértékelési kiigazításra. Valamelyest több tanulmány foglalkozik a partnerkockázat más területeivel vagy éppen általános csődmodellezéssel. Ladoniczki és Váradi (2018) és Béli és Váradi (2017) a klíringházak múködésével és a kezdeti letét számításának módszertanával foglalkoznak, míg Harvan és Koncz (2010) a redukált formájú csődmodellekbe beépíthető korrelációt vizsgálják. Ugyanakkor hazai kutatók néhány nemzetközi tanulmányhoz is hozzájárul- 
tak a partnerkockázat témájában. Így például Savickas et al. (2014) tanulmánya a hitelértékelési kiigazítás érzékenységének meghatározására kínál egy alternatív számítási eljárást.

A hitelértékelési kiigazítás szakirodalmának bemutatása és a téma technikai ismertetése után annak relevanciáját elemzem. Elôször azonban ki kell térnünk a szabályozói környezetre, ugyanis az jelentôs változásokon ment keresztül az elmúlt években.

\subsubsection{Szabályozói reformok}

Ebben a fejezetben azokat a válság óta bevezetésre kerülő szabályozásokat tekintem át, amelyeknek szignifikáns hatása van a partnerkockázatra és a hitelértékelési kiigazításra. A szabályozók a válság tapasztalatait számításba véve számos újítást vezettek be. Ezen reformok közül az alábbiakban a következóket részletezem: partnerkockázat miatti tóke tartalékolási szabályozás, standardizált derivatívák kötelezố klíringje és kötelezô kétoldalú letéti megállapodás nemklíringelt derivatívákra.

A válság kitörését követve, 2009-ben a G20 csoportosulás az OTC piac átfogó reformprogramját indította el. A pittsburghi csúcson négy pontban foglalták össze az OTC piac rendszerszintú kockázatának a csökkentéséhez szükséges lépéseket:

1. Az alkalmazhatóságot figyelembe véve, törekedni kell a standardizált OTC derivatívák tôzsdére történő bevezetésére.

2. Minden standardizált OTC derivatívát klíringházon keresztül kell kötni.

3. Az OTC derivatívák jelentésének centralizálása.

4. Magasabb tôketartalékolás elôírása a nem klíringházon kötött derivatívák esetében.

A célok kitűzését hamar gyakorlati változtatások követték, amelyek bemutatását a lista utolsó elemével kezdem. A banki tőketartalékolás szabályozása a bázeli reformokkal kapcsolható össze. A 2004-ben publikált Bázel II szabályozás már részletes előírásokat tartalmazott a partnerkockázat miatti tóketartalék képzésérôl. Ezekkel összhangban minden a szabályozás hatálya alá eső intézménynek képesnek kellett lennie az egyes pozíciókhoz tartozó nemteljesítéskori kitettség és a kockázati súly mértékek meghatározására. E feladat teljesítésére az intézmények komplexitását figyelembevevô fejlett és standardizált módszerek álltak rendelkezésre. A nemteljesítéskori kitettség meghatározására vagy a korábban bemutatott komplex technikákat használó belsô modellezési (IMM) eljárást, vagy a szabályozók által előírt standardizált módszert (CEM) kellett használni. A kockázati 
súlyokat is vagy a belsô minősítésen alapuló módszerrel becsülve, vagy az eszköztípusokhoz rendelt, kevésbé kockázatérzékeny szabályozói súlyok alkalmazásával lehetett megadni.

A dolgozat szempontjából különösen fontos lépés volt a Bázel III szabályozási gyújtemény 2010 decemberi publikálása, és annak 2011 júniusi véglegesítése. Ahogy azt fentebb bemutattam, a Bázel II szabályok már foglalkoztak az OTC derivatívák nemteljesítésének a kockázatával, azonban azok a partnerkockázat értékét még figyelmen kívül hagyták. Korábban viszont láttuk, hogy a partnerkockázat beépül az árba, így annak változása azonnali veszteséget tud generálni. Részben ez a kockázat motiválta a pittsburghi csúcs negyedik pontját. A válság során ugyanis jelentôs veszteségek voltak betudhatóak a partnerkockázat piaci újraárazása miatt. Így a Bázel III szabályozás bevezette a CVA tôketartalékolást, amely a CVA mozgásából adódó jövőbeli veszteségek miatti tôketartalék képzését jelenti. A tartalék képzése mellett, a bázeli szabályozás harmadik pillérjében leírt jelentési előírások miatt a bankok kötelesek annak mértékét nyilvánosságra hozni. Így például a JP Morgan Chase \& Co 2015 év végén 46 milliárd, míg a Goldman Sachs 2018 második negyedévében 34 milliárd dollárnyi kockázattal súlyozott eszközt jelentett a CVA tókeszabály alatt.25 Mindazonáltal a Bázel III szabályozás sem tekinthetô véglegesnek. A CVA miatti tôketartalékolás szabályozása egy reformon megy keresztül. Ennek egyik elemét a 4. fejezetben részletesebben elemzem.

Szintén jelentôs szabályozásnak tekinthetô a G20 pittsburghi lista második pontjának eleget tevô reform, amely a standardizált OTC derivatívák kötelező klíringjét írja elő. A kötelező klíring bevezetését a tengerentúlon a „Dodd-Frank” törvény, míg Európában a „European Market Infrastructures Regulation” (EMIR) és az azokat követő kiegészítések rögzítették ${ }^{26}$ A két régió szabályozása valamelyest különbözik egymástól, de mindkettô a pénzügyi piacok szereplőinek jelentős részére vonatkozik. Ugyan különbözô feltételekkel, de mindkét törvény hatálya alól mentesülnek az OTC piacokon kevésbé aktív nem pénzügyi vállalatok.

${ }^{25}$ JP Morgan Chase \& Co jelentése elérhető: https://jpmorganchaseco.gcs-web.com/ static-files/b49aa43a-1806-476b-9ed8-f08a39b1c1ba. A Goldman Sachs jelentése elérhetô: https://www.goldmansachs.com/investor-relations/financials/current/other-information/ 2q-pillar3-2018.pdf

${ }^{20}$ A teljes Dodd-Frank törvény elérhetô az alábbi linken: https://www.cftc.gov/sites/default/ files/idc/groups/public/@swaps/documents/file/hr4173_enrolledbill.pdf. EMIR által elöírt klíring részletei megtalálhatóak az alábbi linken: https://www.esma.europa.eu/regulation/ post-trading/otc-derivatives-and-clearing-obligation 
Az EMIR és a Dodd Frank törvényt kiegészítő CFTC előírások ${ }^{27}$ specifikálják a standardizált termékek körét, amelyek az OTC derivatívák széles körét lefedik. Természetesen a standardizált jelző komoly jelentéssel bír. Egyrészt többnyire csupán a legegyszerúbb termékek esetében alkalmazható a klíring, így például egy opcióval ellátott kamatláb derivatíva mentesül a kötelező klíring hatálya alól. Másrészt gyakran az egyszerú termékek sem kerülhetnek a kötelező klíring szabályai alá, azok specifikussága miatt. Így például az egy névre szóló hitelmulasztási ügyletek esetében sincs kötelező klíring. Hull et al. (2010) tanulmánya éppen a klíringelt termékek limitáltsága miatti hatékonyság romlást emeli ki. E mellett a kötelezô klíring megvalósítását más kritika is érte. Az európai és amerikai ügyletek szétválasztása, valamint általánosabban az adott eszköztípust klíringelő létesítmények nagy száma ronthatja a klíring hatékonyságát. Ennek veszélyeire mutatnak rá Duffie és Zhu (2011), akik kiemelik, hogy a partnerkockázat emiatt akár nőhet is.

Még a Nemzetközi Fizetések Bankjának honlapján elérhetô, és a következő bekezdésben bemutatásra kerülő kötelező kétoldalú letét szabályozási javaslata is kiemeli, hogy a derivatívák jelentôs állománya, amely akár több száz billió dollárnyi névérték is lehet, nem standardizált és nem klíringelhetô. A fentiek alapján láthatjuk, hogy a kötelezô klíring alkalmazhatósága limitált, és annak kockázat csökkentô hatása megkérdőjelezhetô. Mégis a szabályozói preferencia egyértelmúen ebbe az irányba mutat. Ennek elsôdleges okát Gregory (2014) a klíringházak válság alatti erôs teljesítményében látja.

Részben a fentebb kifejtettek miatt, a G20 2011-es cannes-i találkozóján egy ötödik pont is felkerült a korábbi reformlistára. Ennek célja a kötelező kétoldalú letéti megállapodás bevezetése minden nem klíringházon keresztül megkötött OTC derivatíva esetében. A javaslat részletes kidolgozását a BCBS (Basel Committe on Banking Supervision) és az IOSCO (International Organization of Securities Comissions) végezték el, és annak végleges formáját többszöri konzultációs periódus után, 2015 márciusában hozták nyilvánosságra. ${ }^{28}$

A javaslatot ugyan valamelyest eltérô formában, de mind az amerikai, mind pedig az európai törvényhozás elfogadta és hivatalossá tette. Az új szabályozások értelmében minden pénzügyi és szisztematikusan fontos nem pénzügyi vállalat, amelyek közvetlenül egymással OTC megállapodást kötnek, kötelesek letéti megállapodással kiegészíteni a keretszerződést. A letéti megállapodásnak változó (VM) és kezdeti letétet (IM) kell tartalmaznia. A változó letét feltételei napi le-

${ }^{27}$ A Dodd-Frank törvényben nem szerepelt a kötelezô klíring hatálya alá eső termékek leírása. Ezt a feladatot a Commodity Futures Trading Commission (CFTC) látja el, amely rendelkezései az alábbi linken érhetőek el: https://www.cftc.gov/LawRegulation/ DoddFrankAct/Rulemakings/ClearingRequirement/index.htm

${ }^{28}$ A végsó változat elérhetó az alábbi linken:https://www.bis.org/bcbs/publ/d317.pdf 
téti hívást és nulla küszöbérték használatát írják elő, miközben a kezdeti letétet is figyelembe vevô minimális utalási összeg értéke 500000 euró. A kezdeti letét célja, hogy fedezze a partner csődjétól a pozíció zárásáig eltelt periódus alatt fellépó lehetséges jövóbeli kitettséget. A BCBS-IOSCO javaslat a kezdeti letét egy szélsôséges meghatározását írja elő, ami szerint a letétnek fedeznie kell a pozíció értékében bekövetkezô azt a változást, amely megegyezik a 10 napos likviditási periódus melletti 99\% konfidencia szinten számolt kockáztatott érték (Value at Risk - VaR) mérôszámmal. Ezt az értéket nettósítási csoport szinten kell meghatározni, vagy a szabályozó által előírt standard módszer, vagy piaci stresszt is lefedô intervallumon kalibrált belső modell segítségével. A szigorú követelményeket enyhítő feltétel az 50 millió eurónál meghatározott küszöb, ami alatti kezdeti letétet nem kell elhelyezni.

Az európai és a tengerentúli törvények több apróbb ponton is különböznek, ezek részletes leírásához a FieldFisher által készített tanulmányt javasolom ${ }^{29} \mathrm{Az}$ egyik legfontosabb különbség azonban a bevezetési időintervallum és annak feltételei. A változó letét bevezetése mindkét régióban 2017 márciusában történt, míg a jelentôsebb újításnak számító kezdeti letét bevezetése hosszabb és eltérô késleltetéssel történik. A szakaszos bevezetés legfontosabb dátuma az Egyesült Államokban szeptember 1, hiszen 2016-tól minden évben ekkor bơvül a szabály hatálya alá esố vállalatok száma. Egy vállalat ugyanis az általa tartott OTC derivatívák névértékének a függvényében mentesülhet a törvény kötelezettsége alól. Így 2016-ban a törvény még csak a legalább 3000 milliárd dollár névértékú derivatív állománynál többel rendelkezô vállalatokra vonatkozott, addigra ez 2018 szeptemberére már 1500 milliárd dollárra csökkent, majd végül a tervek szerint 2020 szeptember 1-tôl tûnik el a küszöb. Az európai kötelezô kezdeti letét bevezetésének elsố napját közel fél évvel az amerikai bevezetés utánra halasztották, de ezután szinkronizálták a határidőket. Egy fontos különbség azonban így is megmaradt, ami szerint a küszöbérték még 2020 szeptember 1. után sem lesz zéró. Így a legfeljebb 8 milliárd eurónyi névértékú származtatott termékkel rendelkezô partnerek kivételt képeznek a törvény alól. A törvény csakis a bevezetési dátumok után megkötött derivatívákra vonatkozik.

A BCBS-IOSCO által kiadott dokumentum két pontban magyarázza a letéti követelmények elônyét. Elsőként, állításuk szerint a kötelezô letéti megállapodás bevezetése várhatóan csökkentetni fogja az egyes csôdesemények után a piacon fellépő fertőzéseket és a veszteség továbbterjedését. Másrészt a fokozott letéti kötelezettségek megnövelik a kétoldalú megállapodások költségét, amely a feleket a klíring felé fogja elmozdítani.

${ }^{29}$ A tanulmány elérhető: https://www.fieldfisher.com/media/5054275/margin-rules-12-16-v4. pdf 
Ugyan ahogy azt már korábban ismertettem, a letéti megállapodás hasznos kockázatcsökkentő eszköz lehet, a fenti megállapításokkal mégsem tudok teljesen egyetérteni. Az elsô a válság során megtapasztalt események szöges ellentétjét állítja. A válság globális méretűvé válásának az egyik legfontosabb oka az úgynevezett repo roham, avagy árnyékbank roham volt. Gorton és Metrick (2012) alapján a válság alatt a repok fedezését ellátó mechanizmusok hozzájárultak a válság globális méretúvé válásához. Az értékpapírok árának zuhanását két hatás gyorsította fel. Egyrészt a fedezetet biztosító felek folyamatos letéti hívásokat kaptak, amit csakis eszközeik likvidálásával tudtak teljesíteni, másrészt a csôdeseményeket követô nagymértékú értékpapír eladások tovább csökkentették azok árát. Ezek a megfigyelések részben a letéti szabályok prociklikusságát érintik, amelyet számos tanulmány elemzett, köztük Glasserman és Wu (2018) és Murphy et al. (2016). A második állítás implicite feltételezi, hogy az OTC piacok rendszerszintű kockázata a klíringelt tranzakciókra történő áttranszformálásával eltûnik. Ugyan a klíringházak szigorú feltételek mellett múködô intézmények, semmiképpen sem állítható, hogy nem hordoznak magukban rendszerszintú kockázatot.

A javaslat más elemeit is számos kritika érte. Így például Cont (2018) a 10 napos likviditási periódus kritikáját fogalmazza meg. Véleménye szerint a likviditásnál a pozíció mérete és a piac mélysége számít, így a minden kategóriára rögzített érték a nagy pozíciókra számolt kezdeti letét alulbecslését eredményezi.

Ahogy láthatjuk a szabályozások területei erôsen összefüggnek. Például a BCBS-IOSCO tanulmány érdekes párhuzamot állít a letét és a tőketartalék között. Mindkettő szerepe a csődeseménykor bekövetkezô veszteségek hatásának a csökkentése. Ezt a mitigációs szerepet azonban jelentôs különbségekkel érik el. Elsôként a tôketartalék a túlélő fél költsége, szemben a letéttel, amit a másik fél garantál. Ezentúl a letét egy dinamikusabb, az adott portfólióra célzott eszköz, miközben a tôketartalék a túlélő fél összes pozíciója között került megoszlásra. A tényleges pozícióra vonatkozó tốketartalék nem az aktuális veszteség ellen véd, hanem az úgynevezett valószínúséggel súlyozott veszteség ellen. Végül a tôketartalékból sokkal nehezebb újabb mennyiséget bevonni.

A fentebbi reformok jelentős változásokat hoztak az OTC piacra. Így érdemes megvizsgálni, hogy az új környezetben hogyan is alakul a hitelértékelési kiigazítás témája.

\subsubsection{A hitelértékelési kiigazítás relevanciája}

Az elôző fejezetekben ismertettem a partnerkockázat alapfogalmait és az OTC piac méretét leíró legfontosabb mérôszámokat. Az alapok után mélyebbre ástam a kitettség és a csődmodellezés kérdéseibe, hogy elvégezhessem a hitelértékelési kiigazítás technikai bemutatását. Ezután a téma elméleti kérdéseivel és az azokra 
adott válaszok értelmezésével folytattam, ahol kitértem a téma szakirodalmának a fejlődésére is. A részletes bemutatás során azonban eddig nem vizsgáltam a téma relevanciájának a kérdését. Így most ezzel folytatom.

Ahogy azt a szakirodalom ismertetése során láttuk, a partnerkockázattal kiigazított ár meghatározását az akadémiai élet már több évtizede fontos feladatának tekinti. Az OTC piacokon fellépô partnerkockázat azonban a piacot uraló számos nézet miatt kevés figyelmet kapott a gyakorlatban. Ilyen nézet volt a „too big to fail", amely a jelentős piaci szereplők kockázatmentességét jelentette, és amely együtt bukott meg a Lehman Brothers befektetési bankkal 2008. szeptember 15-én. Ettől a ponttól kezdve a partnerkockázat bekerült a legfontosabb pénzügyi kockázatok csoportjába. Annak árazása és monitorozása a piaci szereplők mindennapos feladatává vált. A téma fontosságát a szabályozó szervektôl érkezô nyomás tovább emelte. Talán nem túlzás azt állítani, hogy a hitelértékelési kiigazítás témakörében az egyik legtöbbet hivatkozott mondat a Bázeli Bankfelügyeleti Bizottságtól származik. A Bizottság a CVA változásából adódó veszteségek elleni szabályozói tókeszükséglet bevezetésének indoklásakor az alábbi adatot hozta nyilvánosságra: „A globális pénzügyi válság alatt a partnerkockázathoz kapcsolódó veszteségek közel kétharmada a hitelértékelési kiigazítás értékének megváltozásából adódott, és csupán azok egyharmada volt tényleges csődeseményeknek betudható.'

Ez rávilágított a partnerkockázat árának relevanciájára, és arra, hogy a kockázattal kiigazított ár alakulása mellett legalább annyira fontos a kockázatmentes és a kockázattal kiigazított ár különbségét elemezni. A partnerkockázat árazásának nélkülözhetetlenségét a növekedô OTC piac tovább erôsítette. Ahogy korábban bemutattam az OTC piac óriási növekedésen ment keresztül a válság előtti években. Ezzel párhuzamosan a piacon óriási „értékû”” partnerkockázat halmozódott fel. Összességében tehát a piaci szemléletmódban történő strukturális változás, a válság alatt elszenvedett hatalmas veszteségek, a szabályozói aktivitás növekedése a területen és a piac méretének növekedése együtt járultak hozzá a hitelértékelési kiigazítás gyakorlati relevanciájának a növekedéséhez. Mivel azonban a probléma jelentős komplexitást hordozott magában, és mivel az elméleti alapok már korábban megjelentek a tudományos szakirodalomban, ezért az akadémiai életet is foglalkoztatni kezdte a téma. Így a hitelértékelési kiigazítás óriási figyelmet kapott, és a relevanciája megkérdőjelezhetetlen volt.

A jelentős veszteségek azonban ráébresztették a szabályozókat a probléma rendszerszintú jellegére, amelyre válaszul megjelentek az 1.3.2. fejezetben bemutatott szabályozások. Ezek célja az OTC piacokon fennálló partnerkockázat

30 „During the global financial crisis, however, roughly two-thirds of losses attributed to counterparty credit risk were due to CVA losses and only about one-third were due to actual defaults." http://www.bis.org/press/p110601.htm 
csökkentése volt. Ahogy láttuk, a standardizált derivatívák kötelező klíringelése csökkenti a kétoldalú megállapodások számát. Az így megkötött derivatívákra a csődvalószínúségekben bekövetkező jelentős csökkenés miatt az árkiigazítás mértéke is csökken, így azt a piacon elhanyagolhatónak szokás tekinteni. A másik jelentős szabályozói reform a nem klíringelt derivatívák esetében bevezetett kötelezô letéti megállapodás volt. Ez jelentôs mértékű fedezetet biztosít a túlélő félnek, amely miatt a kitettség az esetek többségében szignifikánsan csökken. A kisebb kitettség értelemszerúen kisebb hitelértékelési kiigazítást eredményez. Mindeközben, ahogy azt láttuk az 1.1 1.2. ábrákon, az OTC piac nagysága is csökkenni kezdett. Ezek a tényezők kétségtelenül a hitelértékelési kiigazítás gyakorlati relevanciáját csökkentették. Ezért felmerülhet az a kérdés, hogy fontos-e még a hitelértékelési kiigazítás?

A válaszhoz érdemes több szempontot is figyelembe venni. Kezdjük most a szabályozás részleteinek vizsgálatával. A kötelezô klíring előírás a megkötött derivatívák jelentôs részét érinti. Az 1.3 . ábrán láthatjuk, hogy bizonyos kockázat típusokra (például hiteltermékek) látványos növekedést láthatunk a klíringelt pozíciók arányában, de az is világos, hogy más esetekben (például kamatláb termékek) az arány egy szinten stagnál az elmúlt 3 évben. Mivel a szabályozás csakis a standardizált termékek klíringjét teszi kötelezôvé, így természetes, hogy egy szinten túl nem nôhet a teljes klíringelt névérték aránya. Az OTC piac létezésének egyik legfontosabb oka pedig éppen a pozíciók testreszabhatósága iránti igény megléte. Így a nem standardizált termékek állománya mindig is jelentős marad. Ha például az elmúlt évek változatlan adataiból következtethetünk arra, hogy a kamatláb derivatívák elérték klíringelt arányuk elméleti maximumát, akkor azt mondhatjuk, hogy a teljes állomány közel negyede soha nem lesz megköthetô klíringházon keresztül. Ez még a 2018 év végi névérték adatokat használva is több, mint 100 billió dollár. Továbbá más jellemzôen kisebb kockázat típushoz tartozó derivatívák esetében a klíringelt arány közel zéró.

Nem állítható, hogy a klíringelt pozíciók esetében a hitelértékelési kiigazítás szerepe elhanyagolható lenne, de erre még visszatérek. Most azonban szúkítsük az elemzést a nemklíringelt derivatívákra. Ezekre az esetekre született meg a kötelező kétoldalú letét szabályozása. A korábbi leírás alapján világos, hogy a megnövelt rendelkezésre álló fedezet célja a partnerkockázat csökkentése. A kitettség csökkentése redukálja a hitelértékelési kiigazítást, de nem eliminálja azt. Ezekre a pozíciókra továbbra is számítani kell a CVA értékét. Itt különösképpen fontos a kivételek elemzése. Láthattuk, hogy a feleknek speciális letéti megállapodást kell kötniük, amelyben a változó letét szabályai szigorúnak tekinthetôk, de a kezdeti letét csak az igazán nagy pozíciókat fogja érinteni a magas küszöbérték használata miatt. Ebben az esetben a jövőidő használata is megfelelő, hiszen a kezdeti 
letét elhelyezése csupán 2020 végétől lesz releváns a törvény által érintett, kisebb intézményeknek. Ugyan a változó letét szabályozás már aktív, de mégsem szabad megfeledkeznünk azokról a derivatívákról, amelyeket az előtt kötöttek. Ezekre ugyanis nem vonatkozik a letéti kötelezettség. A BIS statisztikái alapján 2018 végén a hitelderivatívák közel 10 százaléka 5 évnél hosszabb lejáratú volt. Miközben a kamatláb termékek esetében a teljes állomány közel negyede 5 évnél hosszabb lejáratú. Ugyan nem állnak rendelkezésre részletesebb adatok, de fontos, hogy a kamatláb ügyletek esetében akár több, mint 40 év lejáratú termékek is előfordulnak. A hosszú lejáratú pozíciók tehát jelentős partnerkockázatot hordoznak magukban, és várhatóan még hosszú ideig hozzájárulnak a CVA tartalékokhoz a letéti szabályozás kivétel miatt.

Így tehát megállapíthatjuk, hogy a szabály hatálya alól ideiglenesen, vagy éppen állandósultan mentesülő derivatívák és a küszöbérték alá esô termékek esetében továbbra is fontos feladat marad a partnerkockázat árazása. A legújabb eredmények azonban arra engednek következtetni, hogy a letéti feltételeknek eleget tevô derivatívák esetében számított partnerkockázat csökkenés elmarad a korábban várt mértéktól. Már korábban említettük Brigo et al. (2014) tanulmányát, akik rámutattak, hogy hitelderivatívák esetében a változó letét nem tudja jelentôsen csökkenteni a CVA értékét. Az újabb eredmények viszont sokkal általánosabb következtetést vonnak le. Így például Andersen et al. (2017a) rámutatnak, hogy kamatláb derivatívák esetén a hitelértékelési kiigazítás kezdeti letét mellett is szignifikáns lehet az úgynevezett kitettség profil tüskék miatt. A kitettség profil tüskék a korábban bemutatott fejlett kitettség modell alapvető elemei, amelyek a csődesemény közeli események megfelelő modellezéséból erednek. Andersen et al. (2017a) numerikus eredményei szerint egy két év lejáratú kamatláb csereügylet esetében a hitelértékelési kiigazítás a BCBS-IOSCO szabályozás feltételei mellett a letét nélkül számolt CVA negyedére csökken, amely szignifikáns hatékonyság vesztés a korábbi elemzések 99\%-os redukciós rátájához képest. Andersen et al. (2017a) kiemelik, hogy ha egy partnerrel számos kamatláb pozíció áll fenn, akkor a tüskék száma megsokszorozódhat, így jelentôsen megnövelve a kitettséget és hitelértékelési kiigazítást. Így tehát a nézet, miszerint a kezdeti letét teljesen eltünteti a partnerkockázatot téves ${ }^{31}$ Más szerzők is megfogalmazták a kezdeti letét hatékonyságára vonatkozó kritikát. Gregory (2015) a kezdeti letétet, mint egy negatív küszöbértékkel kiegészített változó letétként mutatja be. Ugyan számításai alapján a küszöbérték további csökkentése redukálja a CVA értékét, de annak üteme nemlineáris és egy szint után már a marginális CVA redukció szignifikáns

${ }^{31}$ Hasonló következtetésre jutnak a szerzők egy másik munkájukban is ahol kezdeti letét helyett a változó letétet elemzik. Andersen et al. (2017b) rámutatnak, hogy a kitettség fejlett modellje alapján számolt hitelértékelési kiigazítás a klasszikus modellek által adott érték többszöröse is lehet. 
költségekkel jár.

A hitelértékelési kiigazításban bekövetkezô változások ügylet szintű elemzésétől eltávolodva a rendszerszintû számokat is megvizsgálhatjuk. Így például a bankok által jelentett CVA tőketartalékok mértékét is felmérhetjük. A mérlegfőösszeg szerinti három legnagyobb Egyesült Államokbeli bank által a CVA tókeszabály alatt jelentett kockázattal súlyozott eszközérték 2015 végén 145 milliárd dollár volt, amely 2017 végére 101 milliárd dollárra csökkent.32 Ugyanez a szám még 2018 második negyedévében is 93 milliárd dollár volt, amely még mindig a hitelértékelési kiigazítás relevanciáját támasztja alá.

Végül egy téma relevanciáját más témákra gyakorolt hatása alapján is felmérhetjük. Így tehát érdemes megnézni, hogy a CVA területén elért eredmények felhasználhatóak-e más témák esetén. Egy jelentôs területet biztosan meg tudunk nevezni, ahol is a CVA az egyik szülő szerepét játssza: ez az XVA témája. Az elmúlt évek szabályozói reformjai jelentôs változásokat okoztak az OTC piacokon. Ezeket részben áttekintettük, de az XVA-t eddig a pontig nem említettük. Az XVA egy átfogó elnevezése a derivatív szerződések árát kiigazító tényezőknek. Az eddig bemutatott CVA valójában csak egyike a számos árkiigazítási faktornak. Ugyan a CVA a legelterjedtebb és a legkevésbé vitatott, de rajta kívül még megkülönböztetjük az alábbiakat: FVA, MVA, KVA. Minden egyes ilyen kiigazítás valamilyen költség számszerúsítése, amelyet részben a szabályozások idéztek elő. Ezen kiigazítások számítása gyakran nagyon hasonló módszertanon alapul, mint a CVA számítása. Így szintén minden, a CVA területén elért eredmény az XVA területét is gazdagítja. Az ilyen jellegú kiigazítások egyre fontosabbakká válnak, amelyet az is jól mutat, hogy a bankok XVA részlegeket hoztak létre, amelyek a különböző árkiigazítások számolásáért és fedezéséért felelősek. Ezekkel a kiigazításokkal részben azok vitatottsága és sok esetben kezdetlegessége miatt nem foglalkozok a dolgozatban. Az érdeklôdő Olvasónak Gregory (2015) és Green (2015) könyveit ajánlom bevezetésnek.

A fentiek alapján megállapíthatjuk, hogy a hitelértékelési kiigazítás továbbra is jelentôs relevanciával bír. Annak számos problémája azonban továbbra is

32 A mérlegfőösszeg szerinti három legnagyobb bank a JP Morgan Chase, a Bank of America és a Wells Fargo. Mivel nem ezek a legnagyobb derivatív kereskedók, ezért más bankok nagyobb kockázattal súlyozott eszközértéket jelenthetnek, de már ezek a bankok is jól mutatják a CVA jelentőségét. A 3. pillér alapú jelentések elérhetőek a bankok honlapjain.

- JPM https://jpmorganchaseco.gcs-web.com/financial-information/ basel-pillar-3-us-lcr-disclosures,

- BoA: http://investor.bankofamerica.com/phoenix.zhtml?c=71595\&p=irol-baselholdingarchive\# fbid=TjsbYWSzPFR,

- Wells Fargo:https://wellsfargo.com/about/investor-relations/basel-pillar-3-disclosures 
megoldatlan, ${ }^{33}$ így a téma a mai napig érdekes kihívások elé állítja a kutatókat.

\section{4. Összefoglalás}

Ezzel befejezem a hitelértékelési kiigazítás bevezetését. A következő fejezetekben a jelölések felidézése és a független olvashatóság miatt röviden átismétlem a legfontosabb fogalmakat, de azok részletes leírásáért ehhez a fejezethez érdemes visszalapozni.

A dolgozat hátralévô részében az általam elért eredményeket mutatom be. Mivel a kutatás a téma egyes komponenseinek részletesebb vizsgálatával járt, ezért az egyes fejezetekben számos szakirodalmi hivatkozást használok, amelyek a fentiekben nem szerepeltek. Ezek jól kiegészítik a fenti szakirodalom összefoglalót, de érthetôen témájuk sokkal specifikusabb.

${ }^{33}$ Hasonló gondolatok olvashatóak ki Damiano Brigo egyik nemrégiben megjelent vélemény cikkéból is https://www.risk.net/comment/5441561/xva-back-to-cva 


\section{2. fejezet}

\section{A kitettség profil és a hitelértékelési kiigazítás meghatározásának numerikus módszerei}

Az OTC piacokon aktív szereplók egymás felé fennálló kitettségük megfelelő mérése és monitorozása jelentôs munkát jelent a felek partnerkockázattal foglalkozó osztályainak. Ahogy az 1.2, fejezetben kifejtettem: a partnerkockázat alatt az OTC piacokon megkötött derivatív szerződések élettartama során, a partnerek lehetséges nemteljesítéséből eredő veszteség kockázatát értem, amely kockázattípus két ponton különbözik a klasszikus hitelkockázattól. Míg egy hitelszerzôdés során a felek egyértelmúen hitelezô és adós kategóriákba oszthatóak, és a hitelezô kitettsége egy jól meghatározott mennyiséggel leírható, addig a partnerkockázat esetén ezek nem teljesülnek. Mivel egy OTC derivatív szerződés értéke minden esetben az aktuális piaci faktoroktól függ, így a fennálló kitettség is folyamatosan változik. Ebból adódóan a kitettség értéke akár egyik napról a másikra előjelet is válthat, így felcserélve az adós és a hitelezô szerepét. Éppen ezen okok miatt a kitettség meghatározása egy bonyolult, számításigényes feladat.

A bevezető fejezetben részletesen bemutattam a jövóbeli kitettség és a hitelértékelési kiigazítás legfontosabb fogalmait. A technikai fejezetekben számos formulát megadtam, amelyek alapján a különbözó partnerkockázati mennyiségek számszerúsíthetőek. A legtöbb formula azonban szemi-analitikus alakot vett fel és számos komplex tényezôt foglalt magában. Általános esetekben ezek a mennyiségek nem számíthatóak analitikusan. Jelen fejezetben azzal foglalkozom, hogy a szemi-analitkus formák milyen numerikus módszerekkel számszerúsíthetőek.

A gazdasági világválság tapasztalatai és a szabályozói nyomás a bankok kockázatkezelési osztályait jelentős fejlődésre kényszerítették. A partnerkockázat mérése és árazása a terület fejlődésével párhuzamosan vált egyre komplexebbé. Mára már általánosnak tekinthető, hogy a bankok összetett hitel és partnerkockázati 
folyamatai óriási erőforrásokat használnak fel. Különösen számításigényes múveletnek számítanak az egyes partnerek felé fennálló jelen és jövóbeli kitettség meghatározása és a nemteljesítési kockázat árazása, azaz a hitelértékelési kiigazítás számítása.

A bankok a partnerkockázat méréséhez klasszikusan Monte Carlo szimuláción alapuló árazási módszereket használnak. A pontos becslés jellemzôen a szimulált alapfaktorok útjainak magas számát kívánja meg, ami a számítási igény nagyon gyors megugrását eredményezi egy több ezer partnerrel, több millió ügyletet megkötő nagy piaci szereplőnél. Ezért a számítási kapacitás szükséglet csökkentése nem csupán egy elméleti szempontból kívánatos feladat, hiszen az komoly költségcsökkenéshez vezethet.

A fejezetben két numerikus módszert vezetek be, amelyek a számítási kapacitás két különböző dimenziója szerint javítják a hagyományos módszerek teljesítéményét. Elsôként a kitettség profilok meghatározásához szükséges futási idő csökkenését érem el egy új eljárás meghatározásával, amely a többszintú Monte Carlo módszerre támaszkodik. A többszintú Monte Carlo módszer egy széleskörben alkalmazott technika, azonban tudomásom szerint kitettség profilok számítására még nem alkalmazták. A fejezet második részében egy speciális numerikus módszer, a legkisebb négyzetes Monte Carlo technikán alapuló hitelértékelési kiigazítás számítását javítom és annak jelentôs memória igényét csökkentem. Mindkét esetben megadom a módszerek implementálásához követendő eljárást és numerikus példákon is bemutatom azok teljesítményét. A fejezet független olvashatósága és a fejezetben használt alapfogalmak felidézése miatt rövid partnerkockázati ismertetéssel indítok. Átfogóbb leírást az 1. fejezetben találhat az Olvasó.

\subsection{A kitettség profilok becslése többszintü Monte Carlo módszerrel}

Egy derivatív szerzôdés adott pillanatban vett értéke meghatározza az azonnali kitettség értékét, azonban a felek jellemzően hosszabb távon is szeretnék tudni (várható) kitettségüket. Így például a bankok óriási számítási kapacitást használnak a kitettség profilok becslésére. A profilok a jövóbeli kitettség valamilyen statisztikai mértékének időbeli függvényeik. Ilyen például a gyakran előtérbe kerülő várható pozitív kitettség profil, amely maga is számos további fontos mennyiség inputja. A bázeli nemteljesítéskori kitettség a nemcsökkenő, várható pozitív kitettség profil első évig tartó integrálja. Ezen túl az így kapott mennyiség a szabályozói partnerkockázati tóketartalék egyik bemeneti paramétere. De hasonlóan fontos szerepet kap a kitettség profil a hitelértékelési kiigazítás számításakor is. 
Jelen alfejezetben egy alternatív módszert, a többszintű Monte Carlo becslést használom a kitettség profilok becslésére. ${ }^{1}$ A módszert eredetileg Heinrich (2001) vezette be parametrikus integrálási feladatokra, majd Giles (2008) ültette át pénzügyi problémákra. A módszert azóta számos esetben felhasználták derivatív árazási feladatokhoz, valamint sztochasztikus alapfaktorok szimulálására, azonban tudomásom szerint Hofer és Karlsson (2017) tanulmánya az elsô munka, ami partnerkockázati keretek közé illeszti azt. Ôk a hitelértékelési kiigazítás értékének különböző paraméterek melletti számolásához vezetnek be egy többszintű Monte Carlo alapú technikát.

A fejezetben a korábbi eredmények által motiválva, a kitettség profilok többszintú Monte Carlo módszer melletti becslését vizsgálom. Bemutatok egy profil becslési algoritmust, ami egzaktan szimulálható sztochasztikus alapfaktorok melletti modellekben használható. Szemben a korábbi horizontális jellegú becslésekkel, jelen fejezetben vertikálisan az idő paramétert használom a többszintű Monte Carlo módszer szintjeinek szétválasztására. Az új módszer szignifikáns számítási teljesítmény növekedést eredményez, így mind a futási idő és a futáshoz szükséges számítási kapacitás csökkenthetô adott pontosságú becslés eléréséhez.

A következô alfejezetben felidézem a legfontosabb definíciókat és jelöléseket, amelyeket a késóbbiekben felhasználok. Ezután bemutatom a többszintú Monte Carlo módszertanát és annak alkalmazását a kitettség profilok becslésére. Ezt a részt egy algoritmussal zárom, ami lépésrôl lépésre mutatja be a javasolt profil becslési technikát. A 2.1.3, alfejezetben egy egyszerú numerikus példában mutatom be módszerem teljesítményét és összevetem azt a hagyományos Monte Carlo becsléssel.

\subsubsection{Alapfogalmak}

Legyen $\left(\Omega, \mathcal{F}, \mathcal{F}_{t}, \mathbb{Q}\right)$ egy valószínúségi mező, ahol $\Omega$ az összes lehetséges kimenet halmaza, $\mathcal{F}$ az összes eseményt lefedô $\sigma$-algebra. A piacon $t$ idôpontig elérhetô információt az $\mathcal{F}_{t}$ tartalmazza. Végül $\mathbb{Q}$ legyen a kockázatsemleges mérték.

Idézzük fel a partnerkockázat-kezelés során használt kitettség fogalmát, amihez tegyük fel, hogy $B$ és $C$ megköt egy $T$ idôpontban lejáró derivatív szerződést. Ha egy rövid idôre feltételezzük, hogy $B$ és $C$ partnerkockázat mentesek, azaz sohasem csődölhetnek, akkor jelölje $\Pi(t, T)$ az általuk kötött derivatív ügylet $t$ és $T$ közötti diszkontált pénzáramainak az összegét $B$ szemszögéből. A kockázatmentes diszkontált pénzáramok összege alapján a következóképpen definiálhatjuk a derivatív $t$-ben vett árát:

$$
V(t)=\mathbb{E}_{t}[\Pi(t, T)]
$$

${ }^{1} \mathrm{Az}$ alfejezet Boros (2018b) tanulmányomon alapul. 
ahol $\mathbb{E}_{t}[]=.\mathbb{E}\left[. \mid \mathcal{F}_{t}\right]$ azaz az $\mathcal{F}_{t}$ filtrációra vett $\mathbb{Q}$ szerinti feltételes várható érték.

Most vezessük be a partnerkockázatot a modellbe azzal a feltételezéssel, hogy mindkét fél a derivatív élettartama során fizetésképtelenné válhat. Csőd esetén a derivatív szerzôdést azonnal zárják, amely esetén a túlélő fél köteles minden tartozását megfizetni a fizetésképtelen partnernek, míg követelésein veszteséget fog elszenvedni. A veszteség a fizetésképtelen partnertől visszaszerezhető értéken múlik, amely arányát rendszerint $R E C_{i}$-vel jelölik, ahol $i \in\{B, C\}$ és $0 \leq R E C_{i} \leq 1$. A lehetséges eseteket B szemszögéból a 2.1. táblázat foglalja össze.

2.1. táblázat. Pénzáramok B szemszögébôl a derivatív csôd miatti zárásakor

\begin{tabular}{|ll|cc|}
\hline & & Követelés & Kötelezettség \\
& $V_{\tau}>0$ & $V_{\tau}<0$ \\
\hline \multirow{2}{*}{ Pénzáram Ideje $(\tau)$} & $\mathrm{B}$ csôdje & $V_{\tau}$ & $V_{\tau} R E C_{B}$ \\
& $\mathrm{C}$ csődje & $V_{\tau} R E C_{C}$ & $V_{\tau}$ \\
\hline
\end{tabular}

Így amikor partnerkockázatról beszélünk, leggyakrabban csak a partnerünk által fennálló tartozás mértékére vagyunk kíváncsiak, hiszen alternatív esetben nem veszítünk az ügylet értékén. Ez a kitettség fogalmának az alapja:

$$
E(t)=\max (0, V(t))
$$

Tehát a $t$ időpontban fennálló kitettség a derivatív piaci értékének pozitív része. Ezt felhasználva definiálhatjuk a várható kitettség profilt, amely a dolgozat alapja lesz:

$$
E E(t)=\mathbb{E}[E(t)]=\mathbb{E}\left[\left(\mathbb{E}_{t}[\Pi(t, T)]\right)^{+}\right],
$$

ahol $(x)^{+}=\max (0, x) !^{2}$ A profilt a gyakorlatban egy $0=t_{0}<t_{1}<t_{2}<\ldots<$ $<t_{m-1}<t_{m}=T$ felosztáson szokás közelíteni. Az így kapott profil pontok lépésközökkel súlyozott átlagát hitel-egyenértékesnek nevezik és az fontos szerepet játszik a tőketartalékolásban. A profil elvezet a szabályozói tóketartalékolásban felhasznált nemteljesítéskori kitettséghez is, hiszen ahhoz az első évhez tartozó, nemcsökkenő $E E(t)$ profilt kell használni. Erről részletesebben a 4 . fejezetben írok.

Láthatjuk tehát, hogy a várható pozitív kitettség profil számítása különösen fontos. A bankok partnerkockázat kezelési részlegei Monte Carlo módszert használnak a profil becslésére. Első lépésként több ezer szimulált utat generálnak az alap piaci faktorokból. Majd a generált faktorok alapján minden szimulációs idôpontban beárazzák az összes partnerrel kötött ügyletet. Ezután az ügyletek mentén aggregálnak és nettósítanak, ahol az engedélyezett. Így meghatározzák

${ }^{2}$ A számítás céljától függốen a külsô $\mathbb{E}[$.$] várható érték ebben az esetben jelentheti a$ kockázatsemleges és a valós mérték alatt vett várható értéket is. 
a jövoobeli kitettség lehetséges útjait. Végül a több ezer út alapján számolják az átlagos kitettséget minden időpontban, minden partnerre. Ez a múvelet óriási számítási kapacitást igényel.

A hagyományos Monte Carlo módszer esetén, $N$ szimulált utat feltételezve a következóképpen adhatunk torzítatlan becslést az $E E\left(t_{i}\right)$ értékére:

$$
\widehat{E E}^{M C}\left(t_{i}\right)=\frac{1}{N} \sum_{j=1}^{N} E^{(j)}\left(t_{i}\right)
$$

ahol $E^{(j)}\left(t_{i}\right)$ a $j$. úton $t_{i}$ időpontban fennálló kitettség.

Jelen alfejezetben egy alternatív Monte Carlo alapú technikát javaslok a kitettség profilok meghatározására, amely szignifikánsan alacsonyabb számítási kapacitás mellett jó becslést biztosít. A többszintû Monte Carlo módszer egy már régóta ismert megközelítés, amely csak nemrégiben került partnerkockázat kezelési felhasználásra. Hofer és Karlsson (2017) a hitelértékelési kiigazítás különböző paraméterek melletti számítására használja módszert. Így például munkájukban foglalkoznak kockázatos kamatláb csereügylet portfólió fix kamatának meghatározásával, vagy éppen a rossz irányú kockázat mérésével. A következô részben ismertetem a módszert.

\subsubsection{Többszintü Monte Carlo a várható pozitív kitettség profil becslésére}

A többszintû Monte Carlo módszerról Heinrich (2001), Giles (2008) és Giles (2015) munkái adnak részletes leírást. Az alapprobléma, hogy egy bizonyos intervallumban mozgó paramétertől függó mennyiséget az intervallum összes lehetséges pontjára szeretnénk becsülni. Így például Heinrich (2001) egy $u(\nu)$ függvényt használ illusztrációnak, ahol

$$
u(\nu)=\int_{0}^{1} f(\nu, t) d t
$$

és $\nu \in[0,1]$. Követve Heinrich (2001) leírását és jelölését, standard Monte Carlo módszer esetén az alábbi becslést alkalmazhatjuk:

$$
\widehat{u}\left(\nu_{i}\right)=\frac{1}{N} \sum_{j=1}^{N} f\left(\nu_{i}, \xi_{j}\right),
$$

ahol $\nu_{i}=\left\{\frac{i}{n}, i=1,2, \ldots, n\right\}$ és $\xi_{j}$ független, egyenletes eloszlású véletlen változók a $[0,1]$ intervallumon, amelyeket minden $i$. mellett újrafelhasználunk. Tetszőleges 
$\nu$ esetén $u(\nu)$ a 2.6 egyenlet alapján interpolálással számítható.

$$
\begin{aligned}
u(\nu) \approx(P u)(\nu)= & \sum_{i=0}^{n} u\left(\nu_{i}\right) \phi_{i}(\nu) \approx \\
& \sum_{i=0}^{n}\left(\frac{1}{N} \sum_{j=1}^{N} f\left(\nu_{i}, \xi_{j}\right)\right) \phi_{i}(\nu)=\frac{1}{N} \sum_{j=1}^{N}\left(\operatorname{Pf}\left(., \xi_{j}\right)\right)(\nu)=\eta(\nu),
\end{aligned}
$$

ahol $P$ az interpolálás operátor és $\phi_{i}(\nu)$ a hozzátartozó súlyfüggvény. Ugyan Heinrich (2001) formalizálása absztraktnak túnhet, mégis a súlyfüggvényen keresztül könnyen specifikálhatjuk a $P$ operátort. Így például lineáris interpolációt használva $i=0,1, \ldots, n$ esetén az alábbi választással élhetünk:

$$
\phi_{i}(\nu)= \begin{cases}\frac{\nu_{i+1}-\nu}{\nu_{i+1}-\nu_{i}}, & \text { ha } \nu \in\left(\nu_{i}, \nu_{i+1}\right] \\ \frac{\nu-\nu_{i-1}}{\nu_{i}-\nu_{i-1}}, & \text { ha } \nu \in\left[\nu_{i-1}, \nu_{i}\right) \\ 0, & \text { egyébként. }\end{cases}
$$

Finomítva a felosztást, bevezethetünk különböző szinteket a becslésbe. Legyen $\nu_{l i}=\left\{\frac{i}{2^{l}}, i=0,1,2, \ldots, 2^{l}\right\}$ és $l=0,1,2, \ldots, L$ valamint $P_{l}$ az $l$ szinthez rendelt interpolálás operátor $3^{3}$ Ha $P=P_{L}$ és $P_{-1}=0$ akkor $P=\sum_{l=0}^{L}\left(P_{l}-P_{l-1}\right)$. Ezt a teleszkopikus összeget a 2.7. egyenletbe behelyettesítve az ott bevezetett becslés a következô formára módosul:

$$
\eta=\sum_{l=0}^{L} \frac{1}{N} \sum_{j=1}^{N}\left(P_{l}-P_{l-1}\right) f\left(., \xi_{j}\right)=\sum_{l=0}^{L} \frac{1}{N} \sum_{j=1}^{N} P_{l} f\left(., \xi_{j}\right)-P_{l-1} f\left(., \xi_{j}\right) .
$$

Végül szintenként vezessünk be eltérô $N_{l}$ szimulációs számot, amivel a 2.9. egyenlet az alábbi végsố alakot veszi fel:

$$
\eta=\sum_{l=0}^{L} \frac{1}{N_{l}} \sum_{j=1}^{N_{l}}\left(P_{l}-P_{l-1}\right) f\left(., \xi_{j}\right)=\sum_{l=0}^{L} \frac{1}{N_{l}} \sum_{j=1}^{N_{l}} P_{l} f\left(., \xi_{j}\right)-P_{l-1} f\left(., \xi_{j}\right) .
$$

A fenti egyenlet tehát azt mutatja, hogy kevésbé finom intervallumon számolt $\nu_{i}$ értékeket újrafelhasználva javíthatjuk a becslést tetszóleges $\nu$ esetén. A javítás mértékét Heinrich (2001) számszerúsítette, amely szerint $\mathcal{O}\left(N^{-\frac{1}{2}}\right)$ hibát $\mathcal{O}(N)$ nagyságú számítási igénnyel érhetünk el, az egyszerú módszer $\mathcal{O}\left(N^{\frac{3}{2}}\right)$ nagyságával szemben. A módszer széles körben használható, de talán ennek egyik velejáró hátránya, hogy nem mindig világos, hogy a $\left(P_{l}-P_{l-1}\right)$ tag pontosan mit is jelent.

${ }^{3} \mathrm{Az}$ intervallum megválasztása számos tényezőn múlhat, amelyeket hamarosan illusztrálok. Az intervallum felezésen alapuló eljárást Heinrich (2001) munkája alapján választottam. Ebben az esetben ugyanis lineáris interpolációt alkalmazva a korábban becsült pontok ugyanakkorra mértékben járulnak hozzá a következô pont becsléséhez. 
Ezért egy, a dolgozat témájához közelebb álló szemléletmódot is bemutatok $\bigsqcup^{4}$

Giles (2008) már pénzügyi problémákra vezeti be a módszer egy változatát. Munkájában sztochasztikus differenciál egyenletek által generált alapfaktoroktól függó származtatott termékek árazásával foglalkozik. Legyen $S(t)$ egy sztochasztikus differenciál egyenlet szerint fejlődő alapfaktor értéke $t$-ben, és legyen $G_{l}, l=$ $=0,1, \ldots, L$ egy $h_{l}=2^{-l} T$ lépésköz által meghatározott, a $[0, T]$ intervallumot lefedô, egyre részletesebb felosztásrendszer. Giles (2008) fố kérdése, hogy hogyan becsülhetjük egy derivatív értékét. Ha $f(S(T))$ jelöli egy derivatív kifizetés függvényének értékét $T$-ben, és $P=P_{L}$ annak egy közelítése a legrészletesebb $G_{L}$ felosztás mellett, akkor a derivatív értékéhez az $\mathbb{E}[P]$ mennyiséget kell megbecsülnünk.5 Kihasználva az

$$
\mathbb{E}[P]=\mathbb{E}\left[P_{0}\right]+\sum_{l=1}^{L} \mathbb{E}\left[P_{l}-P_{l-1}\right]
$$

egyenlőséget, és hogy

$$
\mathbb{E}\left[P_{l}-P_{l-1}\right] \approx \frac{1}{N_{l}} \sum_{i=1}^{N_{l}}\left(\hat{P}_{l}^{i}-\hat{P}_{l-1}^{i}\right)
$$

csökkenthetô a szükséges számítási kapacitás. A módszer szerint az adott szinten használt minta elemszámot $\left(N_{l}\right)$ folyamatosan növeljük, miközben $\left(\hat{P}_{l}^{i}-\hat{P}_{l-1}^{i}\right)$ értékét ugyanazon Wiener növekményekkel számolhatjuk, kiindulva a legrészletesebből, majd azokat megfelelően csoportosítva. Így egy apróbb lépésközzel meghatározott időfelosztáson kevesebb mintát használunk fel, mint egy kevésbé részletes felosztásrendszeren. Giles (2008) belátja, hogy ez a becslési technika csökkenti a számítási igényt, hiszen $O\left(\epsilon^{2}\right)$ négyzetes hiba eléréséhez $O\left(\epsilon^{-2}(\log \epsilon)^{2}\right)$ számítási igényre van szükség, szemben az egyszerú becslés $O\left(\epsilon^{-3}\right)$ igényével.

A módszer intuitív megértéséhez vegyük az $L=1$ esetet, ahol is

$$
\mathbb{E}\left[P_{1}\right]=\mathbb{E}\left[P_{0}\right]+\mathbb{E}\left[P_{1}-P_{0}\right] \approx \frac{1}{N} \sum_{i=1}^{N} \hat{P}_{0}^{(i)}+\frac{1}{N_{1}} \sum_{j=1}^{N_{1}}\left[\hat{P}_{1}^{(j)}-\hat{P}_{0}^{(j)}\right] .
$$

A 2.14. egyenlet azt mutatja, hogy egy részletesebb felosztás melletti ár becsléséhez egy kevésbé részletes felosztással becsült árat kontroll változóként használunk fel. Az így kapott megközelítés abban különbözik a hagyományos kontroll változón alapuló becsléstől, hogy a kontrollként használt változó tényleges értéke nem

${ }^{4}$ A probléma egy alternatív megfogalmazásában $\mathbb{E}[f(x, \nu)]$ értékét szeretnénk becsülni, ahol $x$ egy véletlen változó és $\nu \in[0,1]$. Érdemes felírni a 2.10 egyenletet $\mathrm{L}=1$ esetén, mert abból egyszerû lineáris interpolációt feltételezve az alábbit kell látnunk:

$$
\mathbb{E}[f(x, 0.5)]=\frac{1}{2}(\mathbb{E}[f(x, 0)]+\mathbb{E}[f(x, 1)])+\mathbb{E}\left[f(x, 0.5)-\frac{1}{2}(f(x, 0)+f(x, 1))\right]
$$

\footnotetext{
${ }^{5}$ Ha konstans nulla kamatlábat feltételezünk, akkor éppen $\mathbb{E}[P]$ a derivatív értéke.
} 
ismert, hanem azt egy előző szinten becsültük meg. [ $^{6}$ Ennek a különbségnek azonban lényeges implikációi lesznek, ahogy arra még visszatérek.

A jelen alfejezetben támaszkodva Heinrich (2001), Giles (2008) és Hofer és Karlsson (2017) eredményeire egy új módszert fejlesztek a várható pozitív kitettség profil becslésére, amely a többszintú Monte Carlo eljáráson alapul. Eredményem két ponton járul hozzá a szakirodalomhoz. Elsőként, tudomásom szerint ez az első munka, ahol a várható pozitív kitettség profil becslésére használják a többszintú Monte Carlo módszert. Másodsorban, szemben a korábbi munkákkal, itt nem egy modell paraméter mentén alkalmazom a többszintú Monte Carlo módszert, hanem magán az idő paraméteren keresztül. Ugyan Giles (2008) munkája az időfelosztást finomította a Monte Carlo becslés különböző szintjein, mégis mindig ugyanarra az idôpontra, a lejáratra becsülte a számolni kívánt mennyiséget. Az alfejezetben magát a profilt fogom becsülni, azaz úgy tekintek a profilra, mint egy idô paramétertől függó mennyiségre, és a célom, hogy a felosztáson szereplő minden időpontra megadjam a várható pozitív kitettség értékét. A becslés során a profil egyes pontjait különböző szintekhez rendelem, és az adott szinten csak azokat a profil pontokat becsülöm, kihasználva hogy az előzô szinten már vannak becsült pontok. Azaz, az idô paramétert használom változóként és a felosztás finomságát nem változtatom. Ehhez a módszerhez azonban szemben Giles (2008) technikájával nem szimulálom a sztochasztikus alapfaktorok teljes útját, hanem azokat egzakt módon generálom. Így módszerem csak korlátozott esetben alkalmazható, de rámutatok, hogy ilyenkor az új megközelítéssel jelentôsen csökkenthető a számítási igény.

A módszer megértéséhez kövessük most annak formalizált leírását. Kiindulásul válasszunk egy $[a, b]$ intervallumot, ahol $[a, b] \subset[0, T]$. A profilt ezen az intervallumon fogjuk becsülni. Ez lehetôséget ad tetszóleges időhorizont lefedésére, amely az alkalmazástól függ. Így például a bázeli nemteljesítéskori kitettség (EAD) számolásához, csupán egy évnyi értékre van szükségünk. Az intervallum megválasztásához más szempontot is figyelembe vehetünk, amit a következő fejezetben részletezek. Jelölje $k=0,1, \ldots, L$ a többszintű Monte Carlo egyes szintjeit és használjuk a Heinrich (2001) által javasolt felosztást. Eszerint a profilt az alábbi értékekkel becsüljük:

$$
\left\{E E\left(t_{j}\right) \mid t_{j}=a+\frac{j(b-a)}{2^{L}}, j=0,1, \ldots, 2^{L}\right\}
$$

Láthatjuk, hogy Heinrich (2001) felosztását követve minden lépéskor az elôzô

${ }^{6}$ Hagyományos kontroll változó melletti becslésnél a kontrollként használt változónak egy konstans szorosát használjuk, amely konstans függ a becsülni kívánt és a kontroll változó kovarianciájától. A többszintú Monte Carlo becslés ebben is eltér a kontroll változók módszerétól, hiszen itt a konstans értéke minden esetben egy. Mindkét észrevétel Giles (2015) munkájához köthető. 
szinten szereplő pontok közé, félúton egy újabb megfigyelési pontot adunk. Így azonban kihasználhatjuk, hogy a becsülni kívánt mennyiség az adott pontot körülvevô értékekben már ismert. Ahogy arra Hofer és Karlsson (2017) is rámutatott, ha ezek között magas korrelációt tudunk elérni, akkor az egyfajta kontroll változón alapuló becslésünk jelentôsen javulhat.

Legyen $t_{j+}$ és $t_{j-}$ az adott $k$ szinten lévô $t_{j}$ idôpontot megelôző és az azt követő időpontok. Ha feltételezzük, hogy $\widehat{E E}\left(t_{j+}\right)$ és $\widehat{E E}\left(t_{j-}\right)$ már ismert, akkor a köztes pontra a következő becslést alkalmazhatjuk:

$$
\widehat{E E}\left(t_{j}, t_{j-}, t_{j+}\right)=\frac{1}{N_{\mathrm{MLMC}}} \sum_{n=1}^{N_{\mathrm{MLMC}}}\left(E^{(n)}\left(t_{j}\right)-\frac{E^{(n)}\left(t_{j-}\right)+E^{(n)}\left(t_{j+}\right)}{2}\right)+\frac{\widehat{E E}\left(t_{j-}\right)+\widehat{E E}\left(t_{j+}\right)}{2},
$$

azaz a $t_{j}$ időpontra vonatkozó becslés során kontroll változóként használjuk az előzố szinten, a két szomszédos pontra megbecsült profil értéket. Erre a 2.3. egyenlet kínál lehetôséget, hiszen:

$$
E E\left(t_{j}\right)=\mathbb{E}\left[\widehat{E E}\left(t_{j}, t_{j-}, t_{j+}\right)\right] .
$$

Hofer és Karlsson (2017) és Giles (2008) minden egyes szinten az alapfaktorok teljes útját szimulálták, és a kontroll változókkal való magas korrelációt az utak újrafelhasználásával érték el. Mivel itt minden becslési pontban csak ugyanarra az idôpontra vonatkozó faktorok értékére van szükség, ezért a teljes út szimulálása elkerülhetô. Így azonban a korrelációt is máshogy kell elérni. Az eljárás során ezért ugyanazokat a véletlenszámokat fogom újra és újra felhasználni, a becslés különböző szintjein.

Ezek alapján Hofer és Karlsson (2017) munkájához hasonlóan, megfogalmazhatjuk a többszintû Monte Carlo algoritmust, ami jelen esetben a várható pozitív kitettséget fogja generálni:

\section{A kitettség profil becslése többszintủ Monte Carlo eljárással}

1. Válaszuk meg az $[a, b] \subset[0, T]$ intervallumot, a végsố Monte Carlo szintjének $L$ paraméterét, az elsô szinten használt szimuláció számát $(N)$ és legyen $k=0$.

2. Generáljunk $N_{0}=N$ független, standard normális véletlenszámot és számoljuk ki a piaci faktorok értékét a $t_{j} \in G_{0}=\{a, b\}$ pontokban. Becsüljük meg $E E\left(t_{j}\right)$-t a 2.4 egyenlet alapján.

3. Növeljük $k$ értékét eggyel: $k=k+1$.

4. Adjuk meg az új szint pontjait a következóképpen:

$$
G_{k}=\left\{t_{j} \mid t_{j}=a+\frac{j(b-a)}{2^{k}}, j=0,1, \ldots, 2^{k}\right\} .
$$


5. Válasszuk meg az adott szinten szereplő szimulációk számát az alábbi módon:

$$
N_{k}=2^{-\frac{3 k}{2}} N
$$

6. Minden $t_{j} \in G_{k}$ és $t_{j} \notin G_{k-1}$ esetén számoljuk ki $N_{k}$ piaci faktort az első $N_{k}$ véletlen normális változót felhasználva és legyen $\widehat{E E}\left(t_{j}\right)=\widehat{E E}\left(t_{j}, t_{j-}, t_{j+}\right)$ a 2.16. egyenlet alapján, feltételezve, hogy $N_{\mathrm{MLMC}}=N_{k}$.

7. Ha $k=L$, akkor megállunk, egyébként visszalépünk a 3. ponthoz és onnan ismételjük az algoritmust.

Az 5. pontban történő $N_{k}$ meghatározást Heinrich (2001) javaslata alapján választottam. Az algoritmus tehát az intervallumon szereplő pontok távolságát felezve folyamatosan újabb idôpontra becsüli a profil értékét. A következô fejezetben egy numerikus példán keresztül szemléltetem a módszer múködését és előnyeit.

\subsubsection{Numerikus eredmények}

A módszer erejének érzékeltetéséhez egy egyszerú kamatláb csereügyletet használok fel. A példában B kap fix kamatot és fizeti az éppen aktuális féléves változó kamatot. Az Olvasó a kamatláb derivatívák árazásához, és általánosan a kamatlábmodellekhez részletes útmutatást kaphat Brigo és Mercurio (2007) könyvében. Ezt a munkát követve felírhatjuk a kockázatmentes diszkontált pénzáramok összegének értékét:

$$
\Pi(0, T)=\sum_{i=\alpha+1}^{\beta} D\left(0, T_{i}\right) \mathcal{N} \rho\left(F-L\left(T_{i-1}, T_{i}\right)\right)
$$

ahol $0=T_{\alpha}<T_{\alpha+1}<\ldots<T_{\beta-1}<T_{\beta}=T$ úgy, hogy $\left\{T_{\alpha+1}, \ldots, T_{\beta-1}, T_{\beta}\right\}$ a kamatcserék idôpontjai és $T_{\alpha}$ az elsô kamatrögzítés idoopontja. Továbbá $\mathcal{N}$ a névérték és $\rho$ az időarányosító faktor, jelen példában fél év. A diszkontfaktort $D\left(0, T_{i}\right)$ jelöli, azaz

$$
D\left(0, T_{i}\right)=e^{-\int_{0}^{T_{i}} r_{t} d t}
$$

ahol $r_{t}$ az azonnali kamatláb folyamat, amit késóbb specifikálok. A fix kamatot $F$ jelenti és a $\left[T_{i-1}, T_{i}\right]$ időszakra vonatkozó változó kamatot pedig $L\left(T_{i-1}, T_{i}\right)$, azaz ha $P\left(T_{i-1}, T_{i}\right)$ a $T_{i}$-ben egy egységet fizető kötvény ára $T_{i-1}$-ben, akkor

$$
P\left(T_{i-1}, T_{i}\right)\left(1+\rho L\left(T_{i-1}, T_{i}\right)\right)=1
$$

összefüggés szerint

$$
L\left(T_{i-1}, T_{i}\right)=\frac{1-P\left(T_{i-1}, T_{i}\right)}{\rho P\left(T_{i-1}, T_{i}\right)} .
$$


Felhasználva a 2.1. és a 2.21. egyenleteket, a kötvény árát az alábbi formában adhatjuk meg:

$$
P\left(T_{i-1}, T_{i}\right)=\mathbb{E}_{T_{i-1}}\left[e^{-\int_{T_{i-1}}^{T_{i}} r_{t} d t}\right]
$$

A 2.1. egyenletbe behelyettesítve a 2.20. egyenletben adott pénzáramokat, és felhasználva a fentebb levezetett összefüggéseket adódik a csereügylet mai értéke:

$$
\begin{array}{r}
V(0, F, \mathcal{N}, \rho)=\sum_{i=\alpha+1}^{\beta} \mathcal{N}\left(P\left(0, T_{i}\right)-P\left(0, T_{i-1}\right)+\rho P\left(0, T_{i}\right) F\right) \\
=-\mathcal{N} P\left(0, T_{\alpha}\right)+\mathcal{N} P\left(0, T_{\beta}\right)+\mathcal{N} \sum_{i=\alpha+1}^{\beta} \rho P\left(0, T_{i}\right) F
\end{array}
$$

A várható kitettség profil számolásához szükség lesz a csereügylet egy tetszóleges $t$ pontban vett értékére is. Tehát ha $T_{\alpha+j}<t<T_{\alpha+(j+1)}$ akkor a fenti egyenletból apróbb levezetéssel láthatjuk, hogy

$$
V(t, F, \mathcal{N}, \tau)=-\mathcal{N} \frac{P\left(t, T_{\alpha+(j+1)}\right)}{P\left(T_{\alpha+j}, T_{\alpha+(j+1)}\right)}+\mathcal{N} P\left(t, T_{\beta}\right)+\mathcal{N} \sum_{i=\alpha+j}^{\beta} \tau P\left(t, T_{i}\right) F
$$

Mivel az előző részben ismertetett módszer egzakt szimulációt használ, ezért ennek megfelelően kell kamatlábmodellt választani. Ez alapján jelen példában az azonnali kamatláb dinamikáját a Vasicek modell (Vasicek, 1977) szerint választom meg. Így legyen $r(t)$ az azonnali kamatláb folyamat és tegyük fel, hogy

$$
d r(t)=k[\theta-r(t)] d t+\sigma d W(t), r(0)=r_{0},
$$

ahol $k, \theta, \sigma$ és $r_{0}$ pozitív paraméterek. Brigo és Mercurio (2007) rámutatnak, hogy ebben a modellkeretben a kötvény ára az alábbi affin szerkezetben adható meg:

$$
P(t, T)=A(t, T) e^{-B(t, T) r(t)}
$$

ahol

$$
A(t, T)=e^{\left[\left(\theta-\frac{\sigma^{2}}{2 k^{2}}\right)(B(t, T)-(T-t))-\frac{\sigma^{2}}{4 k} B(t, T)^{2}\right]},
$$

és

$$
B(t, T)=\frac{1}{k}\left[1-e^{-k(T-t)}\right] .
$$

A kamatláb folyamatot Euler diszkretizálás helyett az alábbi formában szimulálhatjuk egzaktan: 7

$$
r(t)=r(0) e^{-k t}+\theta\left(1-e^{-k t}\right)+\sqrt{\frac{\sigma^{2}\left(1-e^{-2 k t}\right)}{2 k}} X,
$$

ahol $X$ egy standard normális valószínúségi változó. 
2.2. táblázat. A numerikus példában használt paraméterek és a fair csereügylet kamat

\begin{tabular}{ccccc}
\hline$k$ & $\theta$ & $\sigma$ & $r_{0}$ & $F$ \\
\hline 0.01 & 0.05 & 0.05 & 0.01 & 0.005
\end{tabular}

Most megvizsgálhatjuk a többszintú Monte Carlo módszer eredményeit. A példában az ügylet lejárata 9 év és a névérték 100\$. A Vasicek modell paramétereit és a fair fix kamatot a 2.2. táblázatban mutatom be.

Első lépésként bemutatom az elméleti profilt. Ehhez a klasszikus Monte Carlo módszeren alapuló becslést alkalmaztam $N=100000$ szimulált úttal és heti lépésközökkel. A becslést 100 alkalommal végeztem el és az így kapott értékek átlagát tekintettem az elméleti értéknek, amit a 2.1. ábrán szemléltetek. Egyszerú kamatláb csereügyletek esetében a profilt két hatás befolyásolja. A diffúziós hatás alapján az idő előrehaladtával a szimulált piaci alapfaktor eltávolodhat a kiinduló helyzetétől, amellyel párhuzamosan a csereügylet ára is elmozdul a kezdeti nulla értéktől és a pozíció tulajdonosa inkább OTM vagy ITM helyzetbe kerül. 8 Az amortizációs hatás miatt azonban az idő múlásával csökken a még hátralévő fizetések száma, így a partner csődje esetén veszélybe kerülő pénzáram is. Jellemzôen a lefedett időhorizon elsô részében a diffúziós hatás dominál, majd az amortizációs hatás lesz az erôsebb. A kettô együttese tehát kezdetben növekvô profilt, majd általában az idő egyharmada után csökkenô görbét eredményez!9

A következő lépés, hogy különböző feltételek mellett megvizsgáljuk a többszintû Monte Carlo módszer teljesítményét. Összehasonlításként minden esetben a hagyományos Monte Carlo becslést is elvégeztem, és azt is hasonlítottam az elméleti profilhoz. Ahogy arra korábban felhívtam a figyelmet, a becslési intervallum megválasztása mindig a helyzettől függ. Mivel az alapfaktort egzakt technikával szimuláljuk, ezért a folyamat teljes útja és az abból származtatott mennyiségek nem állnak rendelkezésre. A 2.26, egyenletben azonban megjelenik az előző fizetési időpontban fennálló, a következô idôpontban egységnyit fizető kötvény ára $\left[P\left(T_{\alpha+j}, T_{\alpha+(j+1)}\right)\right]$ is. Az egzakt technika miatt ez a mennyiség nem áll rendelkezésre, ezért egy egyszerúsítő feltételre van szükség. Válasszuk meg a becslési intervallumot úgy, hogy a legalsó szinten, a $G_{L}$ halmazban található pontok közel essenek a fizetési idópontokhoz. Ha ugyanis $t_{j} \approx T_{\alpha}$ akkor

$$
\frac{P\left(t_{j}, T_{\alpha+1)}\right)}{P\left(T_{\alpha}, T_{\alpha+1}\right)} \approx 1 \text {. }
$$

Így például a 9 éves lejáratú ügylet esetében $L=4$ választása esetén 6 hónapos

7 Glasserman, 2003)

8 Az OTM és ITM az angol "Out of the Money" és "In the Money" rövidítése.

9 Cesari et al. 2009) 
2.1. ábra. Elméleti profil

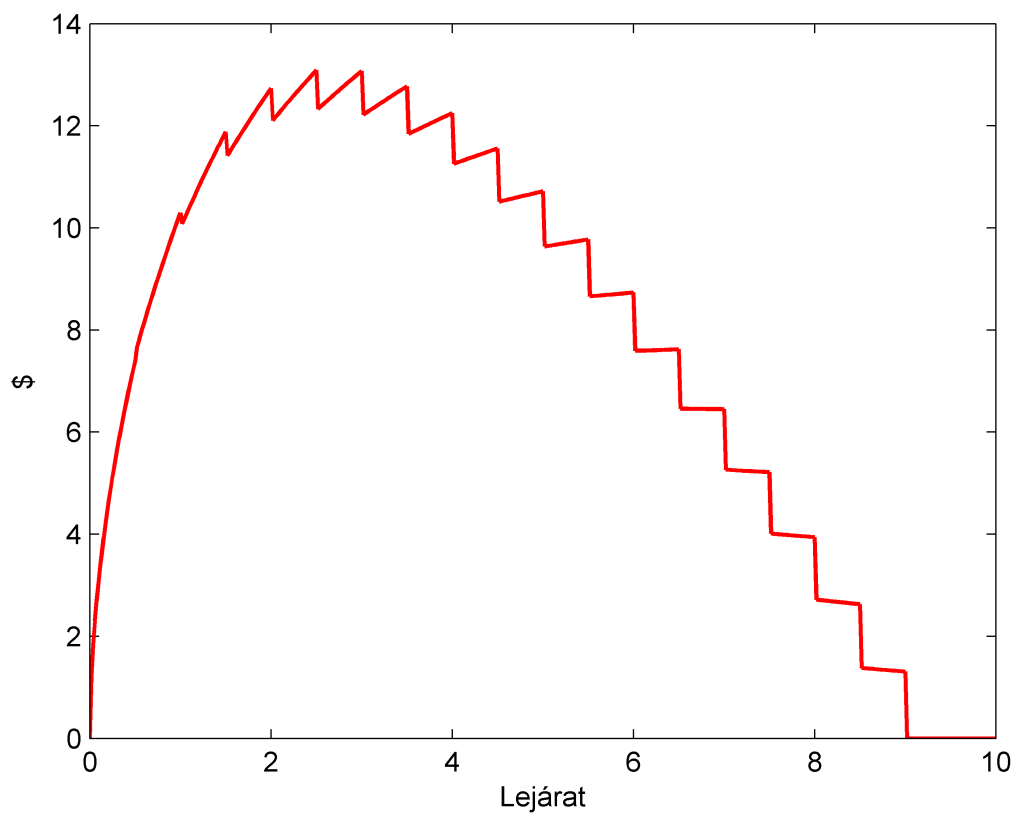

időfelosztást érhetünk el, ha egy 8 éves periódusra szimulálunk.

A 2.2, ábrán a becsült profil egyes pontjaihoz tartozó átlagos standard hibát ábrázoltam különbözô számú szimulált utat feltételezve. Minden esetben 100-szor ismételtem a becslést a megfelelő számú szimulált alapfaktorral és az így kapott hibákat átlagoltam, hogy kiküszöböljem a véletlenszám generátor torzítását. A grafikonok felett látható utak száma a többszintú becslésnél a kiindulási utak számát jelenti, azaz $N=N_{0}$. Az MC rövidítés a hagyományos Monte Carlo módszerre, míg az MLMC a többszintú Monte Carlo módszerre utal.

A hagyományos MC módszer standard hibája követi a profil alakját, és így a széleken kisebb, míg a diffúziós hatás által jobban dominált részen nagyobb értékeket vesz fel. Az ábra alapján a többszintú Monte Carlo módszer a teljes intervallumon kisebb standard hibát ad, mint a hagyományos Monte Carlo árazás, azonban ez félrevezető, ahogy arra rövidesen rámutatok. Az átlagos standard hiba alakja jól értelmezhető, ha figyelembe vesszük az elôző részben közölt számítás módszertanát. A hiba a becslési intervallum két szélén gyakorlatilag egybeér a hagyományos MC módszer által adottakkal, hiszen ezen pontokban ugyanannyi szimulált utat használtam, és nem állt rendelkezésre korábban becsült profil érték, amivel javíthattam volna a becslést. ${ }^{10}$ A következô becslési pont az intervallum felénél, 4.5 év közelében volt. A standard hiba itt a legmagasabb, ami arra enged

${ }^{10}$ Ahogy az ábra is mutatja, kisebb eltérések elképzelhetőek, hiszen a többszintû́ számítás esetén ugyanazokat a véletlenszámokat használtam fel az elsố és az utolsó pont egzakt becsléséhez, míg a hagyományos Monte Carlo módszeren alapuló számolásnál Euler diszkretizálást és új véletlen standard normálisokat használtam. 
2.2. ábra. Standard hiba különbözô szimulációs szám mellett
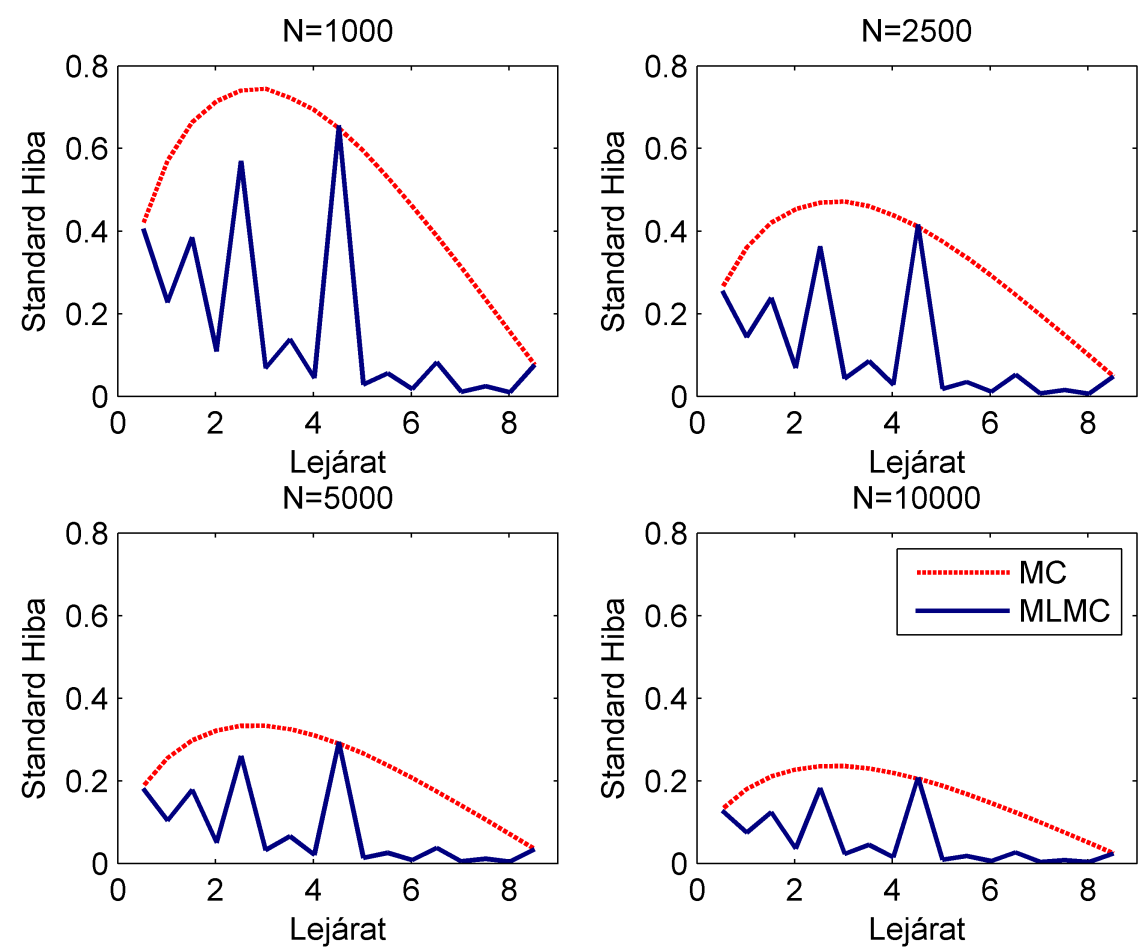

következtetni, hogy a mintaszám közel harmadolását csak kevéssé ellensúlyozzák az intervallum szélein már kiszámolt kontroll változók. Ezután a 2.5 és 6.5 évhez tartozó pontokat becsültem. A szimulált alapfaktorok száma ezen a szinten csupán az eredeti nyolcada, ellenben a kontroll változók közelebb kerültek, így erôsebb hatást tudnak kifejteni. A 2.5 évhez tartozó hiba magasabb, hiszen az eredeti profil is magasabb volt, szemben a 6.5 fél évhez tartozó értékével. A következő szinten a 1.5, 3.5, 5.5 és 7.5 évhez tartozó pontokat becsültem, mindössze az elsố szinthez tartozó szimuláció szám egy-huszonketted részével. Az átlagos standard hiba a szimulációk számának növelésével csökken, de a többszintú módszer látszólagos dominanciája minden esetben megmarad.

Azonban vegyük észre, hogy a hagyományos úton becsült standard hibákkal elkövettünk egy súlyos hibát és a fenti értékek csak akkor lehetnének valósak, amennyiben a hagyományos kontroll változók módszerét használtuk volna. Abban az esetben ugyanis a kontrollként használt változó tényleges értéke egy ismert mennyiség és nem egy becslés értéke. A probléma megértéséhez célszerú a 2.16. egyenletre tekinteni. Amennyiben $\widehat{E E}\left(t_{j-}\right)$ és $\widehat{E E}\left(t_{j+}\right)$ helyett az elméleti, ismert mennyiségek, $E E\left(t_{j-}\right)$ és $E E\left(t_{j+}\right)$ szerepelnének, a variancia becsléséhez azokat figyelmen kívül hagyhatnánk, és a hagyományos standard hibához a következő mennyiséget kellene megbecsülnünk:

$$
\operatorname{Var}\left(\frac{1}{N_{\mathrm{MLMC}}} \sum_{n=1}^{N_{\mathrm{MLMC}}}\left(E^{(n)}\left(t_{j}\right)-\frac{E^{(n)}\left(t_{j-}\right)+E^{(n)}\left(t_{j+}\right)}{2}\right)\right)
$$


2.3. ábra. Az elméleti értéktől vett átlagos négyzetes eltérés különbözô szimulációs szám mellett.
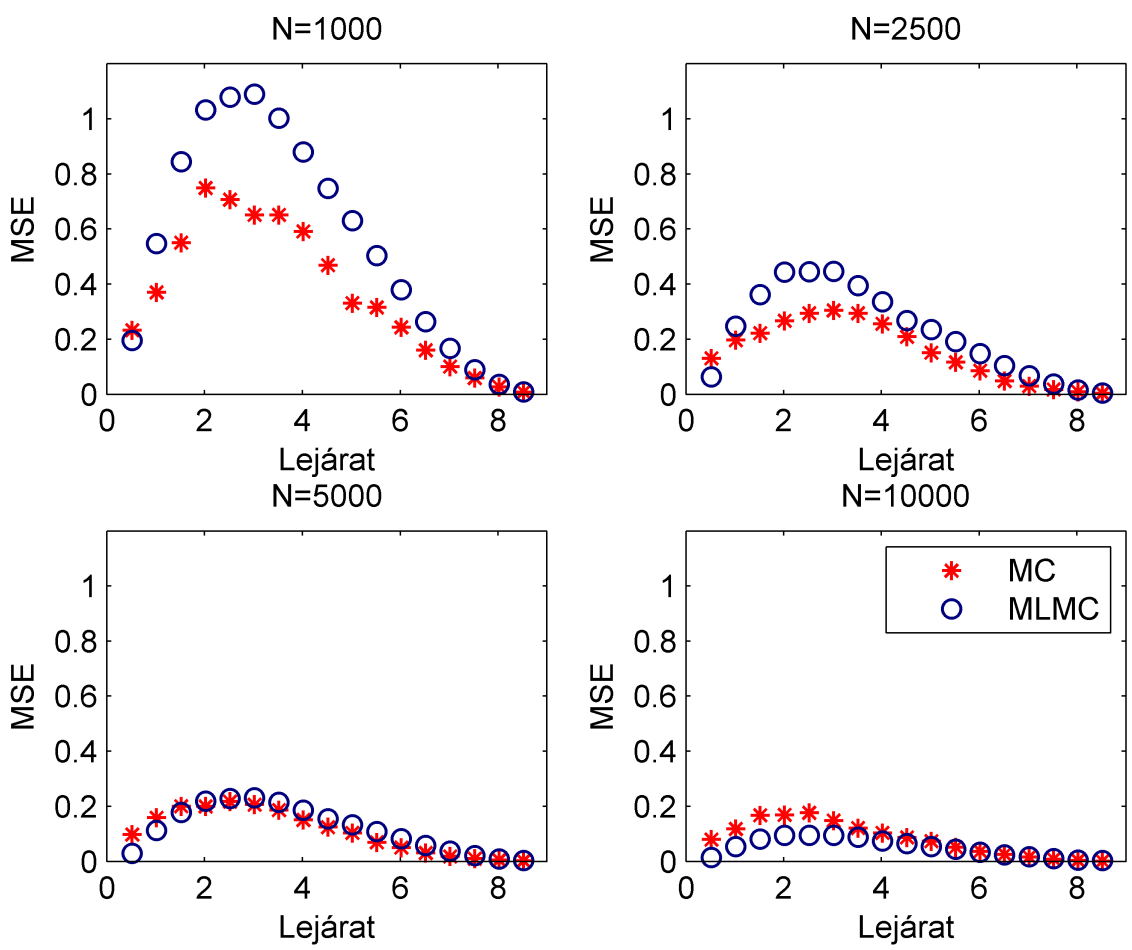

Jelen esetben ez azonban hibás megközelítés, hiszen a profil előzô és következő pontjaira csupán becslés áll rendelkezésre. A becslés hibát hordoz magában, amely hiba bizonyos része az új szinten történő becslésre is hatással van. A 2.16 egyenlet alapján az utolsó tagot nem hagyhatjuk figyelmen kívül a variancia számításánál. Rekurzíven visszahelyettesítve $\widehat{E E}($.$) tagokat azonban azt látjuk, hogy egy adott$ pont becslésénél, az összes korábban felhasznált szomszédos pont hibája számít. Így valójában, ahogy haladunk a szinteken egyre magasabb hibát halmozunk fel.

A módszereket ezért célszerúbb az elméleti értéktől vett átlagos négyzetes eltéréssel összehasonlítani. Hasonlóan a korábbi eljáráshoz, minden vizsgált $N$ paraméter esetében 100 profilt becsültem mindkét módszerrel. Az így kapott profilok az elméleti értéktól vett négyzetes eltérésének az átlagát mutatja a 2.3 ábra. A legkisebb számú szimuláció mellett a módszerem nem teljesített jobban, mint a hagyományos becslés, hiszen az átlagos négyzetes hiba magasabb, mint a hagyományos esetben. Úgy tûnik tehát, hogy az egyes pontoknál jelentkezô, majd kumulálódó hiba itt szignifikáns eltérést okoz. Viszont vegyük észre, hogy a módszerünk gyorsabb ütemben javul, mint a hagyományos MC szimuláción alapuló árazás és az $N=10000$ paraméter számnál a profil összes pontján jobban teljesít. Ekkorra ugyanis a magasabb szinteken lévố pontokon elég szimuláció áll rendelkezésre, hogy a felhalmozódó hiba ellensúlyozható legyen.

Fontos kiemelni, hogy a módszer alacsony szimulációs szám mellett sem rosszabb 
2.4. ábra. Az elméleti értéktól vett átlagos négyzetes eltérés alternatív kiinduló szimuláció számok mellett.

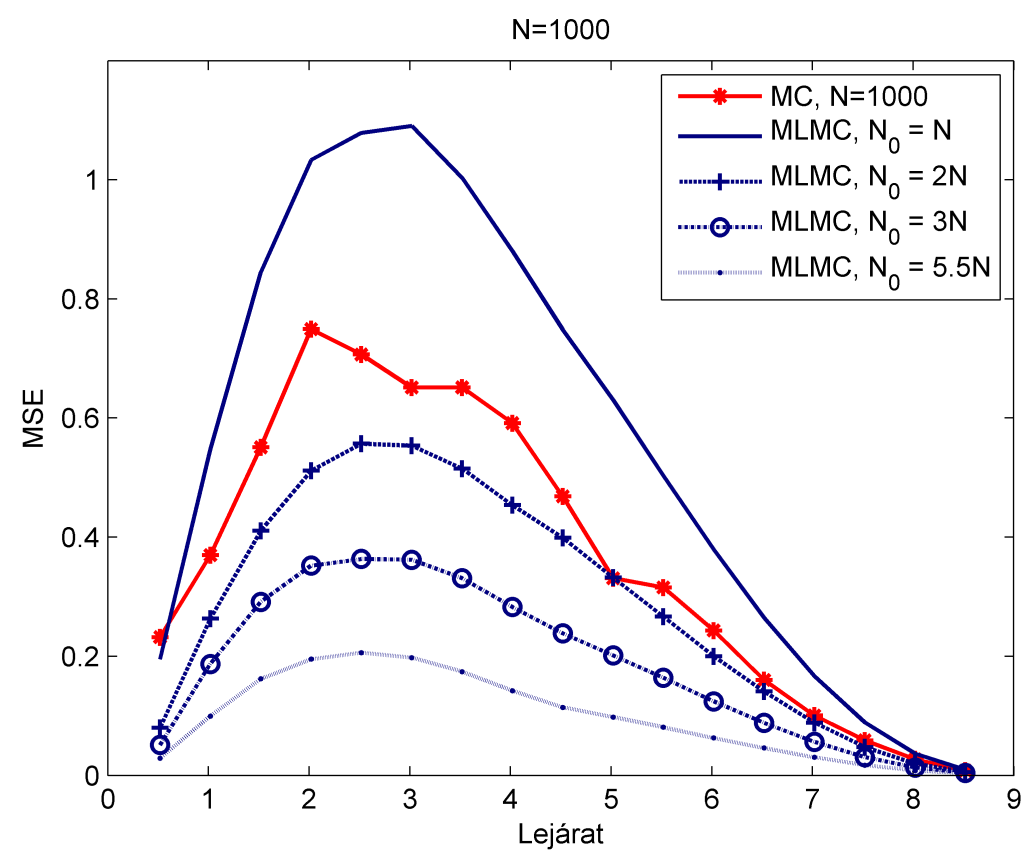

a hagyományos Monte Carlo becslésnél. Az elsố esetben (bal felsố ábra) a hagyományos Monte Carlo módszerrel összesen $17 \times 1000=17000$ adatpontot szimuláltam, és használtam a számításhoz. A többszintú Monte Carlo módszert felhasználva közel 2900 pontra volt szükség 11 Így a kiinduló $N_{0}$ értéket az $N$ többszörösére választva, még mindig kevesebb adatpontot használva lecsökkenthetjük a négyzetes hibát. Ezt szemléltetem a 2.4 ábrán. Láthatjuk, hogy a többszintû módszer hamar előnybe kerül, és végül az $N_{0}=5.5 \mathrm{~N}$ esetben közelíti meg ugyanazt a számítási igényt amit a hagyományos Monte Carlo módszer $N$ szimuláció mellett, miközben szignifikánsan kisebb eltérést generál.

Minden fentebb bemutatott futtatás során megmértem a számításhoz szükséges időt. Ugyan a többszintû Monte Carlo becslés lényegesen kisebb kapacitást igényel, hiszen minden szinten csak az eredeti szimulációs szám töredékével számol, számítási idôben mégsem egyértelmú, hogy jobban teljesít, hiszen szükség van az egyes szinteken lefedett pontok meghatározására, a hozzájuk szükséges szimulációk számának megadására és végül a 2.16. egyenlet számítására. Az eredmények mégis azt mutatják, hogy a számítási idő is eltörpül az új módszerrel. A 2.5 ábrán szemléltetem az átlagos futási idôt a fentebb már leírt szimulációs számok mellett. Azontúl, hogy a javasolt módszer minden esetben gyorsabb volt, az előnye a szimulációk számának függvényében tovább nő. Természetesen az át-

${ }^{11}$ A kezdő szinttel együtt összesen 5 szintet jártam be. Az egyes szinteken becsült pontok számai sorrendben $2,1,2,4,8$. Az szintekhez tartozó szimulációs számok pedig 1000 , $353,125,44,15$. 


\section{5. ábra. Átlagos futási idő}

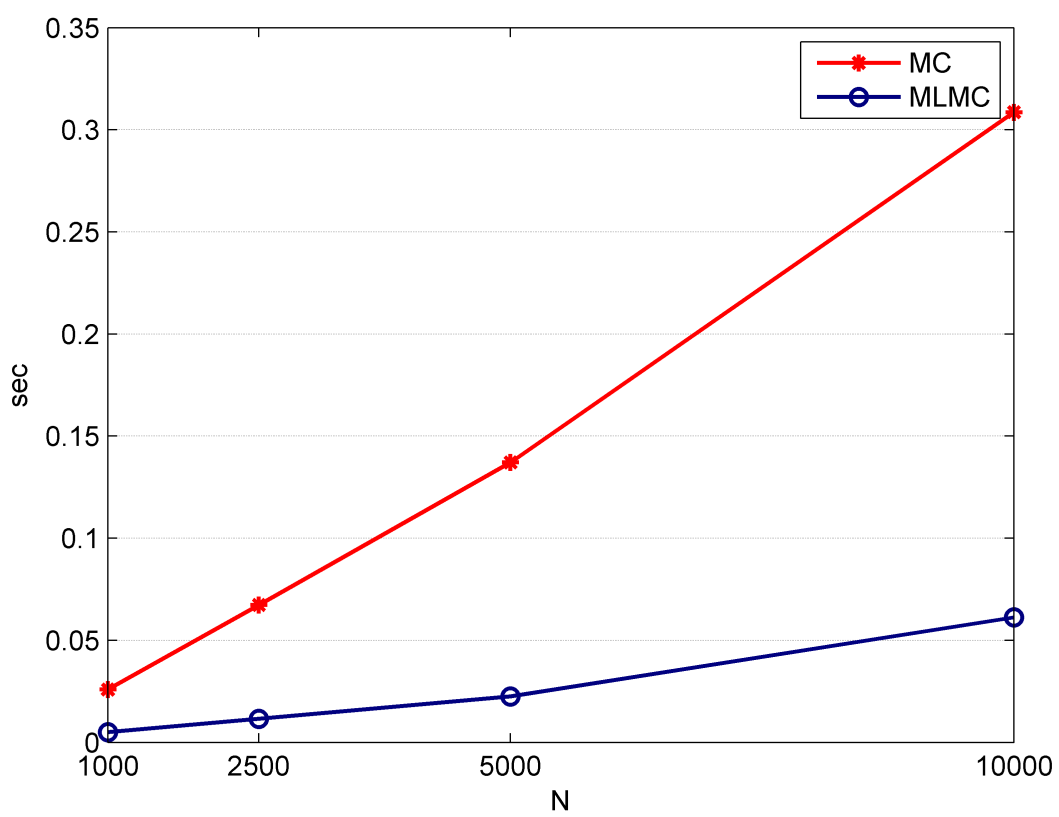

lagos négyzetes hibát leíró pontban kifejtett okok miatt nem érdemes közvetve összehasonlítanunk a futási idôket, de az előző ábra tapasztalatai alapján láthatjuk, hogy $N_{0}=2.5 \mathrm{~N}$ összehasonlításnak már van értelme. Így láthatjuk, hogy az $N_{0}=2500$ pontban mért átlagos futási idố még mindig szignifikánsan elmarad az $N=1000$ esetben mérttól.

A futási idô tovább javítható GPU alapú számítással vagy párhuzamosítással. Az egyes szintek közötti átmenet nem párhuzamosítható, hiszen egy adott szint becsléséhez szükségünk van az előzô szint becsült pontjaira. Ezzel szemben adott szinten belül az újabb osztópontokhoz rendelt profil értékek számítása párhuzamosítható, valamint az idôszükséglet GPU alapú rendszerrel tovább csökkenthetô.

Az alfejezetben tehát az 11. fejezetben ismertetett kitettség fogalmak számszerúsítésének egy lehetséges új módját adtam meg. Eredményeim azt mutatják, hogy a többszintú Monte Carlo módszer szignifikánsan javítja a kitettség profilok becslését, így azt érdemes a gyakorlatban is felhasználni.

A fejezet elsố részét ezzel befejezem. A következó részben egy komplexebb termékekre alkalmazható eljárással foglalkozok. 


\subsection{A hitelértékelési kiigazítás számítása csökken- tett memória igényủ Legkisebb Négyzetes Mon- te Carlo módszerrel}

A várható kitettség profil vagy a hitelértékelési kiigazítás meghatározásának egyik nehézségét a jövőbeli kitettség eloszlásának becslése jelenti. Ahogy azt korábban bemutattam, a hagyományos megközelítésmód egy Monte Carlo szimuláción alapuló eljárással becsli meg ezt az eloszlást. Ennek legfontosabb lépéseit az alábbiak szerint lehet összefoglalni: Elsô lépésként egy diszkretizált időfelosztáson az alapfaktorok szimulált értékei kerülnek generálásra. Ezt követôen az összes szimulált út minden egyes pontjában a termékek analitikus árazása következik. Végül az árakból már minden idôpontra adódik a kitettség eloszlása. Az egyes utakon kapott kitettség értékekből minden idôpontban átlagolással megadható a várható kitettség.

Az 1. fejezetben adott formulákban nem vizsgáltam az ár meghatározásának problémáját, hanem feltételeztem, hogy azt képesek vagyunk megadni. A 2.1. alfejezet numerikus példájánál már szükség volt az ár specifikálására, amihez a levezetett analitikus árazó formula nyújtott segítséget.

Számos komplex derivatív termék esetében azonban nem létezik analitikus árazó formula. Az ilyen típusú termékek árazásához jellemzôen Monte Carlo szimulációt használnak. Amennyiben egy ilyen pozícióra a hagyományos módszerrel szeretnénk meghatározni a várható kitettséget, akkor nagyon hamar számítási kapacitási korlátainkba ütköznénk, hiszen egy Monte Carlo szimuláció minden egyes pontjában újabb Monte Carlo szimulációkat kellene indítani. Ezért a beágyazott Monte Carlo módszer helyett egy másik módszerre van szükség.

A probléma megoldására a gyakorlatban az úgynevezett Amerikai Monte Carlo (AMC) módszereket használják. Számos AMC módszer létezik, de ezek gyökerei az amerikai opciók árazására kifejlesztett Longstaff-Schwartz eljárásra vezethetőek vissza. Az eredeti opció árazási módszert Carriere (1996) és Tsitsiklis és Van Roy (2001) fejlesztették ki és Longstaff és Schwartz (2001) tették népszerúvé. Mivel amerikai jellegú lehívási lehetôséggel rengeteg termék rendelkezik, ezért a Longstaff-Schwartz módszer különösen hasznos eszköznek számít. A széleskörü alkalmazhatóság mellett az egyszerú implementálást szokás még a módszer nagy elônyének nevezni. Az amerikai opció árazására kidolgozott ötletet a partnerkockázat-kezelés is felkarolta, hiszen a kitettség profilok inputja, a jövőbeli ár eloszlása apróbb módosításokkal kinyerhető az eljárásból. Kitettség profilok számítására az elsók között Cesari et al. (2009) adtak meg egy algoritmust. Részletes leírás nélkül egy hasonló eljárást említ a hitelértékelési kiigazítás számítására Brigo és Pallavicini (2007). Longstaff-Schwartz eredeti módszerére legjobban ha- 
sonlító AMC eljárás a Legkisebb Négyzetes Monte Carlo (LSMC) ${ }^{12}$ néven vált elterjedtté ((Kan et al., 2010), (Karlsson et al., 2016), (Joshi és Kwon, 2016)). A hitelértékelési kiigazítás LSMC alapú becslésének egy, a gyakorlatban számos esetben figyelmen kívül hagyott pontjára Joshi és Kwon (2016) hívták fel a figyelmet. A felismerés alapján Joshi és Kwon (2016) továbbfejlesztették az eljárást figyelembe véve bizonyos, a fedezet hatékonyságát korlátozó letéti megállapodásokat is, mint a minimális transzferösszeget és a fedezeti küszöböt. Egy, a valós életben szinte minden esetben fellépő korlátozást, a letét lehetséges késését azonban nem építették a modellbe.

Az LSMC áthidalva a beágyazott Monte Carlo problémát csökkenti a feladat számítási igényét, amely javítás azonban két fontos hátránnyal jár. Elsóként, a módszer a regressziós becslés alkalmazása miatt gyakran pontatlan árat eredményez. A Longstaff-Schwartz eljárás varianciáját és torzítását már számos tanulmány elemezte. Clément et al. (2002) bizonyították, hogy a módszer konvergál, ha a szimulált utak száma a végtelenhez tart. Glasserman (2003) azonban rámutat, hogy a határérték a magyarázó változók számának végessége mellett nem az elméleti ár, hanem egy szuboptimális lehívási szabályhoz rendelt érték, azaz az eljárás ilyen esetben alulról torzított becslést eredményez. A módszer torzításának iránya sem egyértelmú, mert az jellemzően keveri az alul- és a felülbecslés elemeit, így például Kan és Reesor (2012) alapján alacsony útszám mellett éppen felülbecsül.

A második fontos és kevésbé kutatott probléma a növekvő memória igény. Mivel az eljárás először időben elórehaladva szimulál, majd ezeken az utakon visszafelé indulva közelít, az alapfaktorok szimulált útjait folyamatosan a memóriában kell tárolni. Kellő pontosság elérése érdekében elengedhetetlen a szimulált utak számát növelni, ami könnyen megtölti a számítógép memóriáját megállítva a számítást. A probléma egy megoldását Chan et al. (2006) dolgozták ki.

Jelen alfejezet célja a Joshi és Kwon (2016) által javasolt LSMC eljárás kiterjesztése és a hozzátartozó memóriaigény csökkentése. Az alfejezetben felidézem a fedezet késésének lehetséges okait és relevanciáját, és ennek megfelelően kiegészítem az LSMC eljárást. Amint látni fogjuk az így kapott algoritmus ugyan jól teljesít, de jelentôs memóriakapacitást emészt fel, örökölve az amerikai opciók árazásánál már megismert problémát. Ezért felhasználva Chan et al. (2006) megoldását újratervezem az LSMC algoritmust, és egy szignifikánsan kisebb memóriaszükségletú módszert adok meg. Az új eljárás hátránya, hogy a futási ideje elmarad a memóriacsökkentés nélküli módszertól, de amint azt számpéldákon illusztrálom a memóriacsökkentés mértéke jelentôsebb, mint a futási idő növekedése.

${ }^{12}$ Az LSMC rövidítés az eljárás angol „Least Square Monte Carlo” nevéből származik. 
A következô részben a partnerkockázat alapfogalmaival és az LSMC eljárás bemutatásával folytatom. A 2.2.2. alfejezetben egy szúkebb eszközosztályra, korai lehívási opció nélküli termékekre adom meg a hitelértékelési kiigazítást számító, csökkentett memóriaigényü algoritmust. Ugyanebben a részben egy numerikus példán mutatom be a módszer hatékonyságát. A 2.2.3. alfejezetben megadom az algoritmus általános formáját korai lehívhatósággal rendelkezô termékekre, amelyet szintén egy numerikus példán elemzek. Végül a 2.3. alfejezetben egy összefoglalással zárom a fejezetet.

\subsubsection{Az LSMC módszer és a hitelértékelési kiigazítás}

Az LSMC módszer részletes kifejtése előtt kövessük a korábban már bevezetett jelöléseket, hogy megadjuk a hitelértékelési kiigazítás formális alakját. Idézzük fel a 2.1.1. fejezet feltételeit, de most tegyünk egy további lépést. Így jelölje $\Pi(t, T)$ a t és T közötti pénzáramok t időpontra diszkontált értékeinek összegét és $V_{t}$ a derivatív $t$ időpontban vett árát, ahol

$$
V_{t}=\mathbb{E}_{t}[\Pi(t, T)]
$$

Ahogy az 1. fejezetben kifejtettem, a partnerkockázat csökkentésének egyik gyakori módszere a letéti megállapodás (CSA), amely az adóst bizonyos, a szerzôdésben specifikált fedezet letétjére kötelezi. A letétet csôd esetén a túlélő fél likvidálhatja, így az csökkenti a csőd esetén fellépố veszteséget. Amennyiben $C_{t}$ jelenti a CSA által adott letét $t$-beli értékét, akkor a kitettséget az alábbi formában definiálhatjuk:

$$
E_{t}=\max \left(0, V_{t}-C_{t}\right) .
$$

Tökéletes letéti megállapodás mellett nem lenne szükség a kitettség modellezésére, hiszen a letét értéke minden pillanatban megegyezne a derivatív árával. Egy ilyen szerződés fenntartása azonban túlságosan is költséges lenne, ezért a felek egyszerúsítô feltételeket adnak a CSA-hoz. Az alfejezet szempontjából legfontosabb három egyszerúsítés a letét küldés gyakoriságának meghatározása, valamint a minimális transzferösszeg és a letéti küszöb beállítása. A letéti küszöb a derivatív egy meghatározott értéke, amely alatt egyik fél sem rendelkezik letéti kötelezettséggel. Az aktuális transzferösszeg a derivatív értéke és a letét rendelkezésre álló értéke közötti különbség abszolútértéke. Amennyiben az aktuális transzferösszeg a minimális transzferösszeg alatt marad, akkor a felek nem frissítik a letéti számlát. Végül a letét küldésének gyakorisága specifikálja a letét hívásának a gyakoriságát.

Ugyan a kétoldalú CSA szerződéssel rendelkező derivatív megállapodásoknál akár napi szintû letét elszámolás is bevett gyakorlat, a csődeseménykor rendelkezésre álló letét értéke azonban sosem lesz egyenlô a CSA alapján elvárt legutóbbi 
margin hívásnál meghatározott összeggel. Ennek oka a margin periódus (MPR) ${ }^{13}$, amely a legutolsó margin küldésének idôpontjától a pozíció zárásáig eltelt idôintervallum. Jelöljük az MPR hosszát $\zeta$-val, amely standard értéke jellemzően két hét. Az MPR lényegében egy türelmi idôszak, amely elsődleges célja a letét küldésének elmaradását okozó átmeneti likviditási gondok, avagy infrastrukturális problémák miatti csôdjelentés elkerülése. ${ }^{14}$

Ez alapján definiálhatjuk az iparágban széles körben elterjedt modellt a kitettség számítására, amelyre Andersen et al. (2017b) után szokás klasszikus modellként hivatkozni. A klasszikus modell szerinti $t$ időponthoz rendelt kitettség értékét $\left(E_{t}\right)$ az alábbi formában definiálhatjuk:

$$
E_{t}=\left(V_{t}-K_{t}\right)^{+}
$$

ahol

$$
K_{t}=C_{t-\zeta}
$$

ahol $K_{t}$ a $t$ idôpontban ténylegesen elérhetô letét egyenlege, míg $C_{t}$ jelenti a $t$-ben a CSA alapján előírt mennyiséget. Tehát a pozíció zárásakor a rendelkezésre álló letét egyenlege megegyezik az MPR elején elérhető egyenleggel, hiszen közben nem történt újabb befizetés. Amennyiben nem tételezünk fel fedezeti küszöböt valamint minimális transzferösszeget, akkor a CSA alapján elvárt fedezet mennyisége éppen megegyezik a pozíció értékével: $C_{t}=V_{t}$. A fenti egyenletek alapján könnyen láthatjuk, hogy minél hosszabb a margin periódus, a portfólió értéke annál jobban eltávolodhat a fedezeti számlán lévô összegtől. Így megállapíthatjuk, hogy az átlagos kitettség a margin periódussal arányosan nô.

Végül idézzük fel a hitelértékelési kiigazítást definícióját. A fejezetben egyoldalú CVA-t használok, amely szerint a kiigazítást számító fél csődkockázatát figyelmen kívül kell hagyni. A fentiek alapján a hitelértékelési kiigazítást először letéti megállapodás feltételezése nélkül definiálom, de hamarosan beillesztem a fedezetet is a modellbe:

$$
\begin{aligned}
C V A & =\mathbb{E}\left[L G D 1_{(0<\tau \leq T)} D(0, \tau)\left(\mathbb{E}_{\tau}[\Pi(\tau, T)]\right)^{+}\right] \\
& \approx \sum_{i=1}^{m} \mathbb{E}\left[L G D 1_{\left(t_{i-1} \leq \tau<t_{i}\right)} D\left(0, t_{i}\right)\left(V_{i}\right)^{+}\right] \\
& =L G D \sum_{i=1}^{m} \mathbb{Q}\left(t_{i-1}<\tau \leq t_{i}\right) \mathbb{E}\left[D\left(0, t_{i}\right)\left(V_{i}\right)^{+}\right],
\end{aligned}
$$

ahol $D(t, T)$ jelenti a $t$ és $T$ közötti diszkontfaktort és $1_{(.)}$jelöli az indikátor függvényt. Továbbá a második sorban felhasználtam az intervallum egy $0=t_{0}<$ $<t_{1}<t_{2}<\ldots<t_{m}=T$ feloszlását, és azon közelítettem a CVA értékét.

${ }^{13}$ Az MPR az angol "Margin Period of Risk" röviditése.

${ }^{14}$ A teljes MPR idôtartam számos apróbb idôszakból tevődik össze. Ezekról átfogó útmutatást ad Andersen et al. (2017b) munkája. 
Mivel ez nem okoz félreértést, ezért a derivatív árának jelölését egyszerúsítettem az alábbi formára: $V_{i}=V_{t_{i}}$. Végül az utolsó sorban feltételeztem a kitettség és a csődindikátor függetlenségét. Erre az egyszerüsítő feltevésre még a később visszatérek, most azonban folytassuk a Longstaff-Schwartz és az LSMC módszer ismertetésével.

Az amerikai opciók árazásának kihívása a korai lehívhatóság jelenlétéból adódik, amelyre a Longstaff-Schwartz eljárás egy időben hátrafelé haladó, iteratív megoldást kínál. A klasszikus probléma egy részvényre szóló amerikai eladási opció árazása, ahol az opció tulajdonosa nem csak a lejáratkor, hanem addig bármelyik pillanatban úgy dönthet, hogy érvényesíti jogát és értékesíti a részvényét. Az opció árazásához Longstaff és Schwartz (2001) munkája alapján egy alap Monte Carlo szimulációnak megfelelően kell elindulni, kezdve a piaci faktorok útjainak szimulálálásával. Ezután minden úton meg kell határozni a lejáratkor éppen aktuális pénzáramokat, feltételezve, hogy addig nem történt lehívás. Innen időben visszafelé indulva a cél, hogy minden egyes idôpontban egyszerúen meghatározzuk a derivatív folytatási értékét, amelyet akkor ér a termék, ha az adott pillanatban a szerződés nem kerül lehívásra. Az úgynevezett folytatási érték tehát számszerúsíti a jövôbeli esetleges kedvező vagy éppen kedvezôtlen kimeneteket. Amennyiben a folytatási érték ismert, akkor azt összehasonlítva az azonnali lehívás értékével eldönthető, hogy lehívásra kerül-e az opció.

A Longstaff-Schwartz módszer ereje a folytatási érték meghatározásakor válik világossá, ugyanis beágyazott Monte Carlo szimuláció helyett egy legkisebb négyzetek módszerén alapuló regressziós becslést használ. A regresszió magyarázó változói a szimulált alapfaktorokból képzett bázisfüggvények, amelyeket felhasználva a diszkontált pénzáramok összegét, mint eredmény változót próbáljuk magyarázni. A fenti folyamatot a kiinduló időpontig ismételve meghatározhatjuk az amerikai opció értékét. A Longstaff-Schwartz módszer intuitív leírása után, most formalizáljuk a CVA számításához alkalmazott LSMC eljárást, amely során visszatekintünk az eredeti Longstaff-Schwartz módszer egyes elemeire is.

A hitelértékelési kiigazítás számításához a 2.38. egyenletben szereplő összeg egyes tagjait kell meghatározni. Ehhez vegyünk az alapfaktorokból képzett $k$ darab bázisfüggvényt, amiket jelöljön $\xi_{i, j}$, ahol $j=1,2, \ldots, k$ és $i=1,2, \ldots, m$. A folytatási érték $t_{i}$ idôpontbeli regressziós becslése az alábbi alakot veszi fel:

$$
f_{i}=\sum_{j=1}^{k} \beta_{i, j} \xi_{i, j}
$$

ahol $\beta_{i, j}$ a $\xi_{i, j}$ magyarázó változó becsült együtthatója. Az együtthatókat az alábbi négyzetes eltérés minimalizálásával kaphatjuk meg.

$$
\sum_{\omega}\left[\sum_{j=1}^{k} \beta_{i, j} \xi_{i, j}(\omega)-\Pi^{\omega}\left(t_{i}, T\right)\right]^{2} .
$$


A fenti összegben $\omega$ jelöli a szimulált utakat, $\xi_{i, j}(\omega)$ a $j$. magyarázó változó értéke az $\omega$ úton és $\Pi^{\omega}\left(t_{i}, T\right)$ az adott úton vett diszkontált pénzáramok összege. Az eredeti Longstaff-Schwartz módszer szerint a 2.40. egyenletben csak azokat az utakat kell figyelembe venni, ahol a pozíció azonnali lehívása pozitív értékkel jár. Valójában ez a megkötés nem minden esetben segít, így elhagyom ezt a szúkítést. Itt érdemes egy pillanatra megállni és visszatekinteni a módszer felhasználásának korai formájára.

Az eredeti módszer célja korai lehívási opcióval rendelkező termékek árazása volt, és a regressziós közelítéssel a pozíció folytatási értékét becsülték. Minden egyes lehívási időpontban a Longstaff-Schwartz módszer összehasonlította az azonnali lehívás értékét a pozíció folytatási értékével. Amennyiben ekkor egy adott úton a pozíció lehívási értéke volt magasabb, akkor a módszer egy lehívási időpontot talált, és a pénzáramokat a lehívás értékével tette egyenlővé. Alternatív esetben azonban a pénzáramokhoz nem a regressziós becslésból kapott mennyiséget rendelte, hanem az együtthatók becsléséhez felhasznált diszkontált pénzáramokat.

Formálisan tehát a fentebbi regresszió megbecslése után a következóképpen kell frissíteni a pénzáramok értékét $t_{i}$-ben:

$$
\Pi^{\omega}\left(t_{i}, T\right)=\left\{\begin{array}{l}
L_{i}(\omega), \text { ha } f_{i}(\omega) \leq L_{i}(\omega), \\
D\left(t_{i}, t_{i+1}\right) \Pi^{\omega}\left(t_{i+1}, T\right)+\Pi^{\omega}\left(t_{i}, t_{i+1}\right), \text { ha } f_{i}(\omega)>L_{i}(\omega),
\end{array}\right.
$$

ahol $L_{i}(\omega)$ az azonnali lehívás értéke, valamint $\Pi^{\omega}\left(t_{m}, T\right)=f_{m}(\omega)=0$.

Így a fentiek alapján láthatjuk, hogy a Longstaff-Schwartz módszer a becsült regressziós egyenletet nem használja közvetlenül árazásra, hanem csak a korai lehívási döntés meghozására. Erre a szabályra számos szerzớ[15 felhívta a figyelmet, de ennek fontosságát a hitelértékelési kiigazítás számítása során először Joshi és Kwon (2016) mutatta be. Joshi és Kwon (2016) egy alternatív eljárást javasolnak, amit most kövessünk a fenti gondolatmenet pontosabb bemutatásához.

Joshi és Kwon (2016) alapján a 2.38, egyenlet gyakorlatban elterjedt közelítési formája az alábbi:

$$
C V A \approx L G D \sum_{i=1}^{m} \mathbb{Q}\left(t_{i-1}<\tau \leq t_{i}\right) \mathbb{E}\left[D\left(0, t_{i}\right) f_{i}^{+}\right]
$$

A 2.42. közelítés megköveteli, hogy $f_{i}^{+}=V_{i}^{+}=\left[\mathbb{E}_{t_{i}}\left[\Pi\left(t_{i}, T\right)\right]\right]^{+}$. A fenti érvelés alapján azonban ez nem egy elvárható feltétel, hiszen a módszer eredeti felhasználása szerint a regressziós egyenlet más szerepet kapott, és az általa becsült értéket nem közvetlenül az árazáshoz használták. Éppen ezért Joshi és Kwon (2016) egy

${ }^{15}$ Például Kan et al. (2010) vagy Karlsson et al. (2016). 
alternatív közelítést javasolnak:

$$
C V A \approx L G D \sum_{i=1}^{m} \mathbb{Q}\left(t_{i-1}<\tau \leq t_{i}\right) \mathbb{E}\left[D\left(0, t_{i}\right) \Pi\left(t_{i}, T\right) 1_{\left(f_{i}>0\right)}\right] .
$$

A 2.43, egyenletben Joshi és Kwon (2016) kétféle közelítést vezetnek be. Egyrészt a hitelértékelési kiigazítás opció jellege miatt a regressziós függvényt csak a lehívási döntés meghozására használják. A lehívás ebben az esetben értelemszerúen annak eldöntését jelenti, hogy az adott úton a pozíció értéke pozitív-e vagy sem. Eközben a 2.43 . egyenlet az ár közelítésére a jövőbeli pénzáramok diszkontált értékét használja. Ugyanez olvasható ki, ha párhuzamba állítjuk a 2.43. közelítést és az eredeti definíció kissé módosított alábbi alakját:

$$
\begin{aligned}
C V A=L G D \sum_{i=1}^{m} \mathbb{Q}\left(t_{i-1}\right. & \left.<\tau \leq t_{i}\right) \mathbb{E}\left[D\left(0, t_{i}\right)\left(V_{i}\right)^{+}\right] \\
= & L G D \sum_{i=1}^{m} \mathbb{Q}\left(t_{i-1}<\tau \leq t_{i}\right) \mathbb{E}\left[D\left(0, t_{i}\right) V_{i} 1_{\left(V_{i}>0\right)}\right]
\end{aligned}
$$

A közelítés megértéséhez célszerú a partnerkockázatra, mint egy eladott opcióra gondolni, ahol a hitelértékelési kiigazítás az opció díja. A partner a csốdidôpontban hívhatja le az opcióját, amely szerint, ha a pozíció értéke számára pozitív, akkor a teljes követelését megkapja, míg ellenkező esetben csupán a kötelezettségének egy részét, az $(1-L G D)$ által meghatározott arányát teljesíti. Ez a fajta aszimmetria miatt az opció kifizetés függvényét az $L G D\left(V_{\tau}\right)^{+}$alakban adhatjuk meg, amelyból láthatjuk, hogy az opciót a $V_{\tau}>0$ esetben fogja lehívni a partnerünk.

Joshi és Kwon (2016) a fentebb megadott módszert tovább fejlesztik korai lehívási opcióval rendelkezô és anélküli termékeket egyszerre tartalmazó portfóliókra. Továbbá egy lehetséges megoldást kínálnak minimális transzferösszeggel és letéti küszöbbel kiegészített fedezeti szerződéssel specifikált ügyletek hitelértékelési kiigazításának számítására. A megoldásuk szerint a 2.43. egyenletben a regressziós egyenletet fel kell használni a rendelkezésre álló letét megállapítására is, azaz a fedezet meghatározásához feltételezzük, hogy $f_{i} \approx V_{i}$ minden úton. Ez alapján a CSA-ben megadott minimális transzferösszeg és letéti küszöb szabály figyelembevételével könnyen meghatározható a letét értéke. Korábban azonban kifejtettem, hogy a regressziós egyenletnek nem célja a termék értékének a meghatározása, így a $f_{i} \approx V_{i}$ közelítés pontatlan lehet. Joshi és Kwon (2016) ezt a problémát az egyes utak csoportosításával (bundling) próbálják áthidalni. Érvük a Jain és Oosterlee (2015) és Karlsson et al. (2016) által bevezetett SGBM ${ }^{16}$ módszereknél

${ }^{16}$ Az SGBM (Stochastic Grid Bundling Methods) eljárás egy AMC módszerek családjába tartozó technika, ahol azonban a folytatási érték helyett rögtön a derivatív értékét becsülik. 
bevett eljárásra épül, ami szerint a regresszió hatékonysága javítható, ha teljes teret particionáljuk, és az egyes partíciókon külön regressziót becsülünk. Így a $f_{i} \approx V_{i}$ közelítés pontosabbá tehetô.

Módszerük azonban így sem képes a fedezeti összeg késéseit is figyelembe venni, hiszen a 2.38, egyenletben szereplô egyes tagokat idóben hátrahaladva egyesével becsüli. Ha azonban a fedezeti összeg késik, akkor például $t_{i}$ idôpontban a $t_{k}$ idôpontbeli portfólió érték alapján meghatározott fedezetet kell figyelembe venni, ahol $k<i$. Ez ekkor még nem elérhető, így a becslés tagonként nem megvalósítható.

Mint azt hamarosan megmutatom a 2.43 . egyenletben tett apróbb változtatással a klasszikus modellben megadott fedezeti szabály is beépíthető Joshi és Kwon (2016) módszerébe. A javasolt változtatás azonban tovább növeli a hitelértékelési kiigazítás LSMC alapú becslésének már önmagában is magas memóriaigényét. Ezért az alfejezet második célja az eljárás memóriaigényének csökkentés ${ }^{17}$, amit Chan et al. (2006) és Hu és Zhou (2017) eredményeire fogok építeni. A jobb megértés érdekében azonban célszerú előbb egy egyszerû eszköztípusra ismertetni a javasolt eljárást. Így most korai lehívási opció nélküli termékekkel folytatom, és késôbb visszatérek a korai lehívási jog problémájára.

\subsubsection{Korai lehívási opció nélküli termékek}

Mivel eddig a pontig az LSMC eljárást kifejezetten korai lehívási opcióval rendelkező termékekkel együtt említettem, ezért zavaró lehet, hogy most ilyen opció nélküli derivatívák partnerkockázatának az árazásával folytatom. Valójában elég csak a 2.43. egyenletre pillantani és világossá válik, hogy a Joshi és Kwon (2016) által adott módszer ugyanúgy múködik korai lehívási opció nélküli termékekre is. Ez a megfigyelés az összes Amerikai Monte Carlo típusú algoritmusra is igaz, legyen szó akár a kitettség profil vagy a hitelértékelési kiigazítás meghatározásáról. Ugyan számos terméknél nincs szükség regressziós eljárásra, hiszen az analitikus árazó formula megléte pontosabb és gyakran gyorsabb eredményt garantál. Mégis bizonyos esetekben a termék a korai lehívási opció nélkül sem árazható egyszerúen, ami indokolttá teheti az LSMC alkalmazását. Folytassuk tehát korai lehívási opció nélküli termékekre a hitelértékelési kiigazítás LSMC alapú számításának formalizálását.

Ahogy azt korábban láttuk, a 2.43. egyenlet klasszikus kitettség modell melletti számításának fô problémája az egyes mennyiségek idôbeli differenciája volt. A probléma megoldása érdekében elôször bôvítsük a korábban adott modellt. Az

${ }^{17}$ Valójában a memóriaigény csökkentése akár elsődleges cél is lehetne, hiszen a javasolt eljárás ugyanúgy használható az általános LSMC módszerre, mint a javasolt kiegészítésre is. 
$f_{i} \approx V_{t_{i}}$ közelítés mintájára egészítsük ki a 2.43 . egyenletet:

$$
C V A \approx L G D \sum_{i=1}^{m} \mathbb{Q}\left(t_{i-1}<\tau \leq t_{i}\right) \mathbb{E}\left[D\left(0, t_{i}\right)\left(\Pi\left(t_{i}, T\right)-K_{i}\right) 1_{\left(f_{i}-K_{i}>0\right)}\right]
$$

ahol $K_{i}=C_{i-\delta}$ és $t_{j+\delta}-t_{j}=\zeta$. Azaz a 2.45 . egyenletben a letéti számla értékét két helyen is felhasználjuk. Egyrészt az opció lehívásának az eldöntéséhez a becsült regressziós egyenlettel állítjuk szembe, másrészt levonjuk az egyes utakon számolt pénzáramokból, hogy a kitettség nagyságát meghatározzuk. A közelítést a CSA által eloóírt fedezet egyenlegének $\left(C_{i}\right)$ meghatározásához felhasznált $f_{i} \approx V_{t_{i}}$ összefüggés adja, amely alapján minimális transzferösszeg, letéti küszöb és bármilyen más a fedezet hatékonyságát rontó korlátozás nélkül $C_{i}=f_{i}$. Valójában azonban a $t_{i}$ időpontban elérhetô egyenlegre teljesül, hogy $K_{i}=C_{i-\delta}=f_{i-\delta}$. Így az idôben hátrafelé haladó szimulációt alkalmazva, $t_{i}$ időponton még túl kell haladni, hogy a $t_{i}$-beli tényleges kitettség értékét meghatározzuk. Egyszerúen adódik a lehetôség, hogy először teljesítsük az algoritmust fedezet nélkül és számoljuk ki a fedezetet a becsült árak teljes útjából, majd végül helyettesítsük be az így kapott mennyiségeket a 2.45. egyenletbe.

Ez a megoldás azonban sok esetben nem megvalósítható, hiszen jelentôs memóriakapacitást követel meg. A pénzáramok, a regressziós becslések és a fedezet elérhető értékeinek mátrixai újabb, a számítógép memóriájában tárolandó egységek, miközben az LSMC módszer által már egyébként is ott tartott változók, például a szimulált alapfaktorok útjai, már megterhelték az elérhetô kapacitást. Éppen ezért egy alternatív eljárást javaslok a 2.45. egyenlet számítására. Az általam használt eljárás Chan et al. (2006) és Hu és Zhou (2017) amerikai opciók árazására kidolgozott ötletén alapul, amit a következókben röviden ismertetek.

Tegyük fel, hogy a korábban bemutatott Longstaff-Schwartz eljárás segítségével szeretnék árazni egy amerikai opciót, amely kifizetés függvénye akár több piaci faktortól is függ 18 Amennyiben a lejáratig hátralévő időtartamot $M$ intervallumra osztjuk, és ezen a diszkretizált időfelosztáson $N$ számú utat használunk az árazáshoz, akkor a Longstaff-Schwartz módszer szerint elsô lépésként az egyes alapfaktorok $N M$ mátrixának oszlopait szimuláljuk. Második lépésként meghatározzuk a lejáratkori pénzáramokat, feltételezve, hogy az opciót addig nem hívták le, és innen visszafelé haladva elvégezzük az árazást a korábban leírtak alapján. Amennyiben $d$ számú alapfaktorral dolgozunk, akkor Chan et al. (2006) alapján az eljárás memóriaigénye $\mathcal{O}(d M N)$ nagyságrendú lesz, hiszen az alapfaktorok teljes útját a memóriában kell tartani. Chan et al. (2006) azonban rámutatnak, hogy amennyiben az alapfaktorok szimulálását kétszer végezzük el, akkor a memóriaigény $(d+1) N+M$-re csökkenthető. Módszerük szerint az eljárás időben

${ }^{18}$ Chan et al. (2006) egy három részvénybôl álló kosár maximumára szóló opcióval illusztrálják a példát. 
előrehaladó részénél az alapfaktorok útjai helyett csak a szimulációhoz felhasznált véletlenszám generátor állapotát kell elmenteni minden egyes idôpontban. Így később, a hátrafelé haladó árazásnál minden faktor ismét előállítható.

A módszer megértéséhez célszerú egy konkrét példára gondolni, így vizsgáljuk meg az eljárás egyes lépéseit egy egyszerû opció árazásán. Egy osztalékot nem fizetô részvényre szóló egyéves lejáratú amerikai put opció árazásához használjunk $N=100$ utat és $M=12$ lépésközt. Tegyük fel, hogy a részvény árfolyam az alábbi GBM alapján fejlődik:

$$
d S_{t}=r S_{t} d t+\sigma S_{t} d W_{t}
$$

ahol $W_{t}$ egy Wiener folyamat a kockázatsemleges mérték alatt és $S_{0}=100$. Időben előrehaladva a következô lépéseket hajtjuk végre:

- Az $S_{\frac{1}{12}}$ értékek szimulálásához szükség van 100 darab független standard normális eloszlású számra. Mielótt ezeket szimuláljuk a véltelenszám generátor állapotát elmentjük egy $R N G$ vektor elsố elemeként $(R N G[1])$.

- A kiszámolt $S_{\frac{1}{12}}$ értékeket felhasználjuk az $S_{\frac{2}{12}}$ értékek megadásához. Elsôként azonban elmentjük a véletlenszám generátor állapotát az $R N G[2]$-be majd ismét legyártunk 100 darab független standard normális véletlenszámot. Időközben az $S_{\frac{1}{12}}$ értékeket felülírhatjuk az új $S_{\frac{2}{12}}$ árfolyamokkal.

- Ismételjük a fenti eljárást addig, amíg a lejárthoz érünk, ahol meghatározzuk a kifizetés függvények értékét a szimulált $S_{\frac{12}{12}}$ alapján. Vegyük észre, hogy ennél a pontnál a memóriában tároljuk a részvényárfolyamok egy év múlvai értékét az összes útra (100), az opció lejáratkori kifizetés függvényét (100) és a 12 elemból álló $R N G$ vektort a véletlenszám generátor állapotaival, amely éppen $(d+1) N+M$ elem.

- A visszafelé haladáshoz felülírhatjuk az $S_{\frac{12}{12}}$ vektort az $S_{\frac{11}{12}}$ részvényárakkal úgy, hogy azok szimulálásához visszaállítjuk a véletlenszám generátort az $R N G[12]$ állapotba. Ekkor elvégezzük a regressziós becslést és meghatározzuk a lehívási döntést, amely alapján az elôző pontban generált kifizetéseket tartalmazó vektor frissíthető.

- Ismételjük az eljárást, amíg a kiinduló ponthoz nem jutottunk. Az opció ára a végső kifizetés vektorban található értékek átlaga lesz.

Chan et al. (2006) és Hu és Zhou (2017) memóriacsökkentési módszerei a 2.45. egyenlet számításához is felhasználhatóak. A módszer hatékonysága a hitelértékelési kiigazítás számítása során egy kissé romlik, hiszen a termék pénzáramaitól függóen bizonyos, az alapfaktorokból képzett mennyiségeket a memóriában kell 
tartani. Jól érzékeltethetjük ezt három különböző hipotetikus kamatláb csereügylet segítségével, amelyekre az egyes fizetési napokhoz tartozó lebegó kamatozás eltérôen van meghatározva. Elsóként egy hagyományos csereügylet esetében a lebegố kamatot a legutolsó fizetési napon rögzítik, így az az aktuális fizetési napon és elótte már ismert. Ekkor az időben elôre haladó számításnál fontos, hogy a fizetési napokhoz tartozó kötvényárfolyamokat elmentsük a memóriába, hiszen arra szükség lesz az időben hátra haladó rész pénzáramainak meghatározásakor. A második példa a késedelmes kamatláb csereügylet, amely lebegő kamata éppen a fizetéskor kerül meghatározásra. ${ }^{19}$ Ilyen helyzetben nincs szükség a korábbi kötvényárakra, így az algoritmus, szemben az elôzô esettel, az eredeti hatékonysággal múködik. Végül, ha a lebegó kamatot az utolsó fizetéstől eltelt kamatok átlagaként határozzuk meg, akkor a memóriahasználat problémája másodlagossá válik, hiszen a módszerem, valamint a hagyományos LSMC további egyszerúsítô feltételek nélkül nem alkalmazhatóak. Általában igaz ez a megfigyelés ázsiai opciós jelleggel rendelkező termékeknél.

Az előző példa utolsó pontjánál feltételeztem, hogy a részvényár folyamat diszkretizált dinamikája előre- és hátrafelé haladó alakja is a rendelkezésünkre áll. A jobb megértés miatt célszerú megadni egy konkrét sztochasztikus folyamat elöre illetve hátra haladó diszkretizált alakjait.

Jelen munkában CIR ${ }^{20}$ folyamatot használok az azonnali kamatlábfolyamat modellezésére. A következőkben kifejtett eljárás más folyamatokra is alkalmazható mindaddig, amíg képesek vagyunk a folyamat jövóbeli értékét a paraméterekkel és a folyamat múltbeli értékeivel, valamint fordítva a múltbeli értékét a jövőbeli értékek segítségével kifejezni. Ezt a feltételt számos, népszerú sztochasztikus folyamat teljesíti, azonban mégis maradnak olyan esetek, ahol ez nem megvalósítható. Ilyen esetekben az Euler explicit-implicit eljárás, valamint egzakt szimuláció segíthet (Hu és Zhou, 2017). Ezekkel a tanulmányban nem foglalkozom.

Ha $r(t)$ jelöli a CIR folyamat szerint fejlôdő azonnali kamatlábfolyamatot, akkor a folyamat dinamikáját az alábbi formában adhatjuk meg:

$$
d r(t)=\kappa(\theta-r(t)) d t+\nu \sqrt{r(t)} d W(t), r(0)=r_{0}
$$

ahol W(t) egy Wiener folyamat a kockázatsemleges mérték alatt és $\kappa, \theta, \nu>0$. Továbbá feltételezzük, hogy $2 \kappa \theta-\nu^{2}=d>0$ és $r_{0}>0$ amelyek garantálják a folyamat pozitivitását. A folyamat azonban könnyen negatívba fordulhat idóbeli diszkretiziálás esetén. Alfonsi (2005) alapján egy természetes módja a folyamat diszkretizált időfelosztáson történő szimulálásnak az alábbi explicit Euler-

${ }^{19}$ A késedelmes kamatláb csereügylet jó példája a korai lehívási opcióval nem rendelkezô, analitikusan nem árazható termékeknek.

20 Cox et al. (1985) 
Maruyama felosztás lenne:

$$
\hat{r}\left(t_{i+1}\right)=\hat{r}\left(t_{i}\right)+\kappa\left(\theta-\hat{r}\left(t_{i}\right)\right) d t+\nu \sqrt{\hat{r}\left(t_{i}\right) d t} Z,
$$

ahol $d t=t_{i+1}-t_{i}$ és $\sqrt{d t} Z=W\left(t_{i+1}\right)-W\left(t_{i}\right)$ a Wiener folyamat növekményeit reprezentáló normális valószínúségi változó. A Wiener növekmények alsó korlátjának hiánya miatt azonban a diszkretizált folyamat negatív tartományba léphet, ezért Alfonsi (2005) és Brigo és Alfonsi (2005) egy alternatív szimulációs sémát javasolnak.

Az új eljárás egy implicit Euler formát követ, ami a következô alakban adható $\operatorname{meg} 21$ :

$$
\hat{r}\left(t_{i+1}\right)=\hat{r}\left(t_{i}\right)+\kappa\left(\theta-\hat{r}\left(t_{i+1}\right)\right) d t+\nu \sqrt{\hat{r}\left(t_{i+1}\right) d t} Z-\frac{\nu^{2}}{2} d t .
$$

A korábbi $d$-re tett pozitivitási feltétel miatt a fenti forma átalakításával nyert másodfokú egyenletnek egyetlen pozitív gyöke van, azaz $\hat{r}\left(t_{i+1}\right)$ egyértelmúen kifejezhető:

$$
\hat{r}\left(t_{i+1}\right)=\left[\frac{\nu Z \sqrt{d t}+\sqrt{\nu^{2} Z^{2} d t+4\left(\hat{r}\left(t_{i}\right)+\left(\kappa \theta-\frac{\nu^{2}}{2}\right) d t\right)(1+\kappa \theta)}}{2(1+\kappa \theta)}\right]^{2},
$$

továbbá szintén a 2.49. formából egyszerú átrendezéssel adódik a hátrafelé haladó alak is:

$$
\hat{r}\left(t_{i}\right)=\left(\frac{\nu^{2}}{2}-\kappa \theta\right) d t+(1+\kappa \theta) \hat{r}\left(t_{i+1}\right)-\nu \sqrt{\hat{r}\left(t_{i+1}\right) d t} Z .
$$

A fenti elôre- valamint hátrahaladó alakok a faktorok időben elôre- illetve hátrafelé történố szimulálásához használhatók. A fentebbi CIR folyamatra vonatkozó egyenleteket közvetlenül majd a numerikus példában használom újra, hiszen az algoritmust általános keretben adom meg, mégis elôbb célszerúbb volt egy példával illusztrálni az elôre- és a hátrahaladást.

Így már minden rendelkezésre áll, hogy definiáljam a hitelértékelési kiigazítás számításához szükséges, csökkentett memóriaigényû algoritmust. A LongstaffSchwartz módszert jellemzően egy két lépéses folyamatban szokták alkalmazni a torzítás csökkentése érdekében (Kan et al., 2010). Az első körben szimulált utakat csak a regressziós egyenletben szereplő együtthatók becslésére használják és így nem részei az árazásnak. A második körben új utakat szimulálnak, amelyekre már az elóző lépésben megbecsült paramétereket alkalmazzák.

Ezt az eljárást felhasználom a hitelértékelési kiigazítás számításánál, hogy az előrelátás okozta torzítást numerikusan tüntessük el a becslésból. Így az algoritmus a következô alakot veszi fel:

${ }^{21}$ A levezetés elérhetô Alfonsi (2005) munkájában. 


\section{Elsô Futtatás - Regressziós becslés}

1. Adjuk meg a felhasznált utak számát $(N)$, az időfelosztást $\left(0=t_{0}<t_{1}<\right.$ $\left.<. .<t_{m}=T\right)$ és a bázisfüggvényeket $\left(\xi_{., j}, \mathrm{j}=1, \ldots \mathrm{k}\right)$.

2. Szimuláljuk az alapfaktorok $N$ számú útját a $0=t_{0}<t_{1}<.{ }_{.}<t_{m}=$ $=T$ időfelosztáson időben elörehaladva, miközben minden $t_{i}, i=1, \ldots, m$ időponthoz történő véletlenszám generálás előtt elmentjük a véletlenszám generátor állapotát, és csakis az alapfaktorok legutóbbi értékét tároljuk a memóriában.

3. Határozzuk meg a lejáratkori pénzáramokat $\left(\hat{\Pi}\left(t_{m}, T\right)\right)$ minden úton.

4. Határozzuk meg az alapfaktorok előzó pontbeli értékét a következóképpen: Állítsuk a véletlenszám generátor állapotát a legutóbb elmentett értékre és generáljuk le újra a korábban már szimulált véletlenszámokat. Használjuk fel az alapfaktorok jelenlegi állapotát, az idôben hátrahaladó diszkretizált differenciálegyenlet alakot és az újonnan szimulált véletlenszámokat az alapfaktorok egy lépéssel korábbi értékeinek kiszámítására. Végül értékeljük ki a bázisfüggvényeket $\left(\xi_{m-1, j}, \mathrm{j}=1, \ldots \mathrm{k}\right)$ az alapfaktorok alapján.

5. Végezzük el a regresszió illesztését a 2.40 . egyenlet $\beta_{m-1, j}, j=1, \ldots, k$ változók szerinti minimalizálásával, ahol $\Pi\left(t_{m-1}, T\right)=D\left(t_{m-1}, t_{m}\right) \hat{\Pi}\left(t_{m}, T\right)$ minden úton ${ }^{22}$ Mentsük el a regressziós együtthatókat és határozzuk meg az $\hat{\Pi}\left(t_{m-1}, T\right)$ értékeket figyelembe véve az esetlegesen aktuális kifizetéseket.

6. Ismételjük a 4. és 5. pontot általánosan az $m=k$ esetre, ahol $k=m-$ $-1, m-2, \ldots, 1$.

A $k=1$ eset futtatása után következik a második szimulációs kör a hitelértékelési kiigazítás 2.45, egyenlet szerinti alakjának a becslésére. Fontos látnunk, hogy a fedezet késése miatt nem tudjuk az egyenletben szerepló szumma egyes tagjait azonnal kiértékelni, hiszen mint azt korábban kifejtettem, a fedezet értéke az időben hátrafelé haladás miatt nem elérhetô. Ezért az egyes tagokat a lentebb megadott módon késleltetve fogjuk kiértékelni.

\section{Második Futtatás - Kiértékelés}

7. Szimuláljuk az alapfaktorok újabb $N$ számú útját a $0=t_{0}<t_{1}<. .<t_{m}=$ $=T$ időfelosztáson időben előrehaladva, miközben minden $t_{i}, i=1, \ldots, m$

${ }^{22} \mathrm{Az}$ algoritmusban a teljes hátralévố pénzáramok megadására bevezetem a $\hat{\Pi}(., T)$ és a $\Pi(., T)$ jelöléseket. Ahogy a képzési szabályból látszik, ezek között csupán az aznap esedékes pénzáramok kezelésében van különbség, ugyanis $\hat{\Pi}(., T)$ esetében beleszámít az aznapi pénzáram, míg П(.,T) esetében az már kifizetésre került. 
időponthoz történő véletlenszám generálás előtt elmentjük a véletlenszám generátor állapotát, és csakis az alapfaktorok legutóbbi értékét tároljuk a memóriában. Továbbá minden idôpontban meghatározzuk a diszkontfaktorok $D\left(0, t_{i}\right)$ értékét, amelyekból mindig a legújabbat tároljuk el.

8. A lejáratkor az újabb utakon is meghatározzuk a pénzáramok diszkontált értékét $\left(\Pi\left(t_{m-1}, T\right)=D\left(t_{m-1}, t_{m}\right) \hat{\Pi}\left(t_{m}, T\right)\right)$, valamint az elóző időponthoz tartozó alapfaktorokat, és a bázisfüggvények értékeit. A korábban illesztett regressziós egyenlet segítségével megbecsüljük a 2.39. egyenletben adott $f_{m-1}$ értékét. Az $f_{m-1} \approx V_{m-1}$ közelítést felhasználva megadjuk a $K_{m-1+\delta}=C_{m-1}=f_{m-1}$ fedezeti számla értékét. Mivel ekkor a $D\left(0, t_{m}\right)$ és az alapfaktorok $t_{m-1}$-beli értékei rendelkezésre állnak, így $D\left(0, t_{m-1}\right)$ is meghatározható. Ekkor figyelembe véve, hogy a fedezet késéssel történő visszaszolgáltatása miatt még a lejárat után is lehet kitettségünk, megbecsüljük a 2.45. egyenlet alábbi módosított alakjának utolsó tagját:

$$
C V A \approx \sum_{i=1}^{m-1+\delta} L G D \mathbb{Q}_{t}\left(t_{i-1}<\tau \leq t_{i}\right) \mathbb{E}\left[D\left(0, t_{i}\right)\left(\Pi\left(t_{i}, T\right)-K_{i}\right) 1_{\left(f_{i}-K_{i}>0\right)}\right]
$$

ahol $f_{i}=\Pi\left(t_{i}, T\right)=0$ minden $i \geq m$ esetén.

9. Időben visszalépve ismételjük az előző pontbeli eljárást és a 2.52 . egyenlet minden tagját megbecsüljük, feltételezve, hogy $K_{i}=0, i=1, \ldots, \delta$.

Az algoritmus alapján látszik, hogy a késleltetett kiértékelés miatt is romlik a memóriacsökkentés hatékonysága, hiszen az $f$ és $\Pi$ változókat addig a memóriában kell tartani, amíg nem tudjuk kiszámolni a fedezet értékét. Ez a választott időfelosztás és $\delta$ értékén múlik.

Az algoritmus hatékonyságát egy numerikus példán szemléltetem. A példában egy egyszerû kamatláb csereügyletet használtam az analitikus árazó formula megléte miatt, amelyet referencia értékként fogok használni. A csődvalószínúségeket egy egyszerú, konstans intenzitással adott redukált formájú modell alapján számoltam. Vegyük észre azonban, hogy az algoritmus sztochasztikus intenzitással adott redukált formájú csôdmodell használatára is alkalmas. Továbbá az intenzitásfolyamat és az azonnali kamatlábfolyamat korrelációjával akár a rosszirányú kockázatot is a modellhez adhatjuk. Ilyenkor természetesen nem használhatjuk a hitelértékelési kiigazításra korábban megadott alakot, hiszen ott kihasználtuk a csődvalószínúségek és a kitettség függetlenségét. Az egyetlen változtatás, hogy a csődidőpontra feltételes kitettséget kell használnunk, így az árazást és a csődvalószínúség számítást együtt kell elvégeznünk.

A példában az egyszerúbb alak megőrzése érdekében a csődintenzitás paramétert $\lambda=0.05$ szinten rögzítettem. Az így kapott csődvalószínúségeket a 2.6 . 
2.3. táblázat. A numerikus példában használt paraméterek

\begin{tabular}{cccc}
\hline$k$ & $\theta$ & $\sigma$ & $r_{0}$ \\
\hline 0.01 & 0.05 & 0.06 & 0.05
\end{tabular}

ábrán mutatom be. Az LGD értékére a piaci standardnak számító 60 százalékot választottam.

2.6. ábra. Csôdvalószínüségek a felhasznált számpéldában. $\left[\mathbb{Q}\left(t_{i-1}<\tau \leq t_{i}\right)\right]$

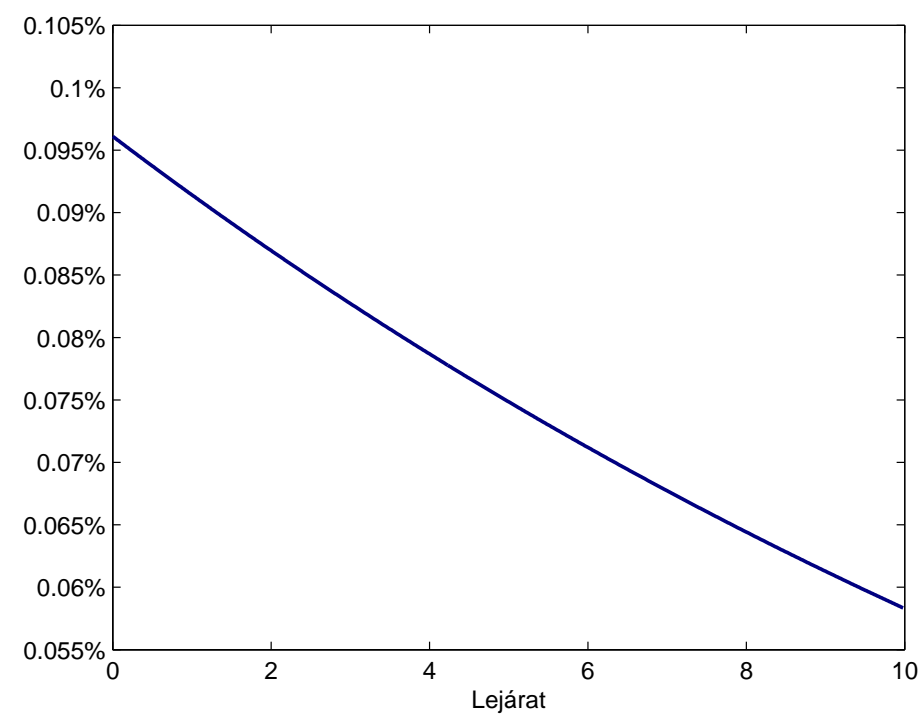

A példában a felek féléves gyakorisággal cserélik el a kamatkifizetéseket, és a derivatíva névértéke 100 egység. Az azonnali kamatlábat leíró CIR folyamat paramétereit Pang et al. (2015) munkáját követve választottam, és a 2.3. táblázatban szerepeltetem. Az elméleti hitelértékelési kiigazítás meghatározásához $N=100000$ utat használtam fel és a kamatláb csereügyletet minden úton analitikus árazó formulával áraztam. ${ }^{23}$ A margin periódust a piacon standardnak számító két hetes intervallummal tettem egyenlôvé. Azért, hogy csökkentsem a fedezet késéséból adódó csúszást az algoritmus 8. és 9. pontjában szereplő kiértékelésben két hetes időfelosztást használtam a derivatíva lejáratáig. Így minden lépésnél képes voltam a 2.52, egyenlet az időben eggyel későbbi tagját meghatározni.

Elsóként megadom a kockázatsemleges mérték alatt becsült kitettség profilt. A profil számításához 100 alkalommal futattam a fentebb specifikált Monte Carlo szimulációt és az így kapott profilok átlagát tekintettem az elméleti profilnak. A 2.7. ábrán a kitettség profilra a klasszikus kitettség modell korábban bemutatott alakjában jellemzô tüskéket láthatjuk. Ezek a fedezet késleltetése miatt

23 Brigo és Mercurio (2007) könyve átfogó útmutatást ad kamatláb derivatívák árazásáról. 
jelentkeznek, hiszen egy-egy fizetési nap után a derivatív értéke nagyot ugorva eltávolodik a margin rendelkezésre álló mennyiségétól, így az azonnal vissza nem térített fedezet magas kitettséget fog generálni. Ennélfogva - ahogy azt már az algoritmusnál is kifejtettem - kitettség még a lejárat után is keletkezhet. Vegyük észre, hogy az ugrást a margin rendelkezésre álló mennyisége az MPR által meghatározott késéssel követi, így a tüskék szélessége éppen $\zeta$ lesz. A kitettség profil a pénzáramok kifizetésére tett további feltételezésekkel kisimítható. Andersen et al. (2017b) azonban rámutatnak, hogy a tüskék szerves részei a kitettség modellezésnek, ezért megtartottam ôket.

2.7. ábra. Kamatláb csereügylet várható kitettség profilja késleltetett fedezettel

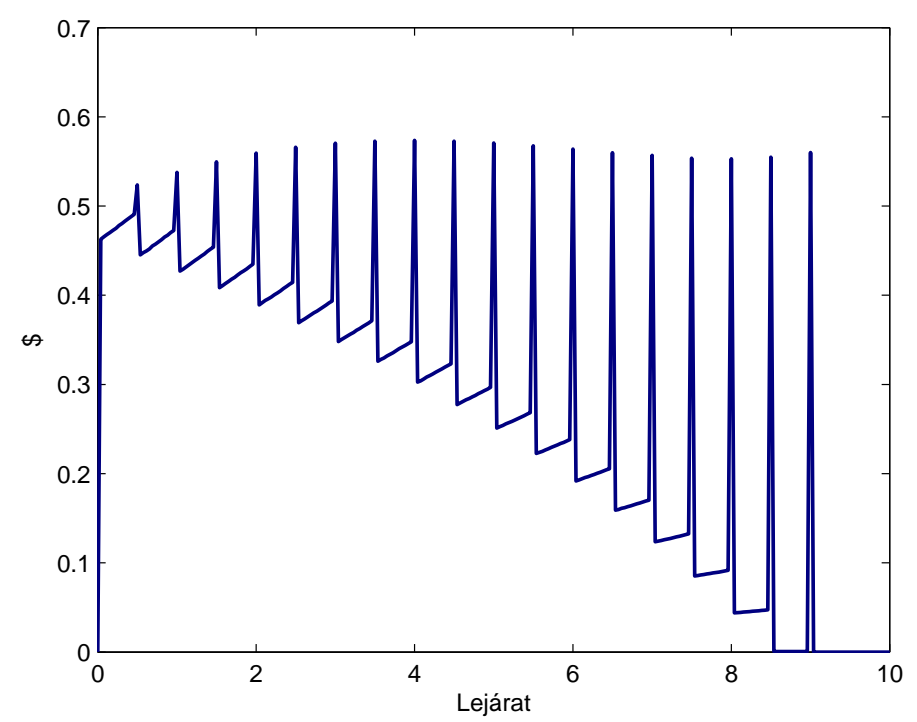

Következő lépésként a hitelértékelési kiigazítás értékét határoztam meg. Az elméleti CVA számításához is ugyanazt az eljárást követtem, mint a profilok becslésénél. Ezenfelül a fentebb adott algoritmust több körben, különbözô számú szimulációs út feltételezése mellett futtattam. Minden esetben a 100 futtatásból kapott hitelértékelési kiigazítások átlagát és az azokhoz tartozó standard hibákat a 2.4 táblázatban közlöm. A futtatás során az azonnali kamatlábfolyamat elsô három hatványát használtam bázisfüggvénynek $\left(1, r, r^{2}, r^{3}\right)$, és minden lépésnél az összes útra egy regressziót becsültem. ${ }^{24}$

Láthatjuk, hogy a regressziós eljárás jól közelíti az elméleti értéket, amelyból arra következtethetünk, hogy az algoritmus 8. pontjában bevezetett $K_{i-1+\delta}=$ $=C_{i-1}=f_{i-1}$ közelítés nem rontja a becslést jelentősen.

Az algoritmus hatékonyságának további vizsgálata érdekében megmértem a

${ }^{24}$ Azaz nem használtam a Joshi és Kwon (2016) által ajánlott lokális regressziós technikát, ami az utak csoportosítása után különbözó regressziót becsül minden egyes csoporton. Ez a technika más, bonyolultabb terméknél azonban hasznos lehet. 
2.4. táblázat. A hitelértékelési kiigazítás 100 futtatás alapján becsült értékei

\begin{tabular}{|c|c|c|c|c|c|c|}
\hline & Analitikus árazás & \multicolumn{5}{|c|}{ Regressziós eljárás } \\
\hline $\mathrm{N}$ & 100000 & 5000 & 25000 & 45000 & 65000 & 85000 \\
\hline CVA & 0.05826 & 0.05942 & 0.05809 & 0.05798 & 0.05788 & 0.05827 \\
\hline Standard hiba & $1.11 \mathrm{E}-06$ & $8.34 \mathrm{E}-04$ & $3.72 \mathrm{E}-04$ & $2.80 \mathrm{E}-04$ & $2.04 \mathrm{E}-04$ & $1.95 \mathrm{E}-04$ \\
\hline
\end{tabular}

csökkentett memóriaigényú módszer maximális memória használatát és futási idejét, amiket összevetettem a 2.45 . egyenlet memóriacsökkentés nélküli eredményeivel is. A 2.8, ábrán látható eredmények szerint a memóriacsökkentés mértéke minden úton közel 30 százalékos mértékú. Ez ugyan elmarad Chan et al. (2006) eredményétől, mégis jelentôsnek mondható. Mivel a memória használat az utak számának növekedésével közel lineárisan változik, így adott kapacitás mellett a csökkentett memóriaigényư módszer közel 30 százalékkal több út szimulálására képes.

A kisebb memória felhasználás elsősorban az alapfaktorok újraszimulálásának technikájából adódik, amelynek viszont ára is van. Így ugyanis minden faktort kétszer generálunk le, amely növeli a számítási időt. Ennek elemzéséhez megmértem a két módszer futásának az átlagos idejét. Az eredményeket a 2.9. ábrán szemléltetem. Láthatjuk, hogy a javasolt eljárás valóban több időt vesz igénybe, azonban a két módszer futási ideje közötti eltérés csekély. Ebből arra következtethetünk, hogy a teljes futáshoz viszonyítva az alapfaktorok újraszimulálása rövid ideig tart, különösen ha a szimulációs utak számát emeljük. A 2.9. ábrán ugyan nehezen vehető ki, de két görbe távolodik egymástól, ahogy a szimulált utak száma nő. Ez összhangban van az újraszimulálás miatt elvártakkal. A távolódás sebessége azonban alacsony, így nem kell attól tartani, hogy az alapfaktorok újraszimulálása miatt túlságosan lelassul az árazás. Mégis érdemes kihangsúlyozni, hogy a példában csupán az azonnali kamatláb folyamatot szimuláltam. Ha az alapfaktorok száma növekszik, a két módszer közötti idóbeli eltérés is emelkedik, míg ezzel párhuzamosan a memóriacsökkentés hatékonyság viszont javul. Módszerem tehát egy alternatív megoldást jelenthet szúkösebb memória tárhellyel rendelkező rendszerekben, ahol az árazás a magas memóriaigény miatt megvalósíthatatlan lenne és így a számítási idő nem az elsődleges szempont. 
2.8. ábra. Memóriaszükséglet a szimuláció során felhasznált utak függvényében

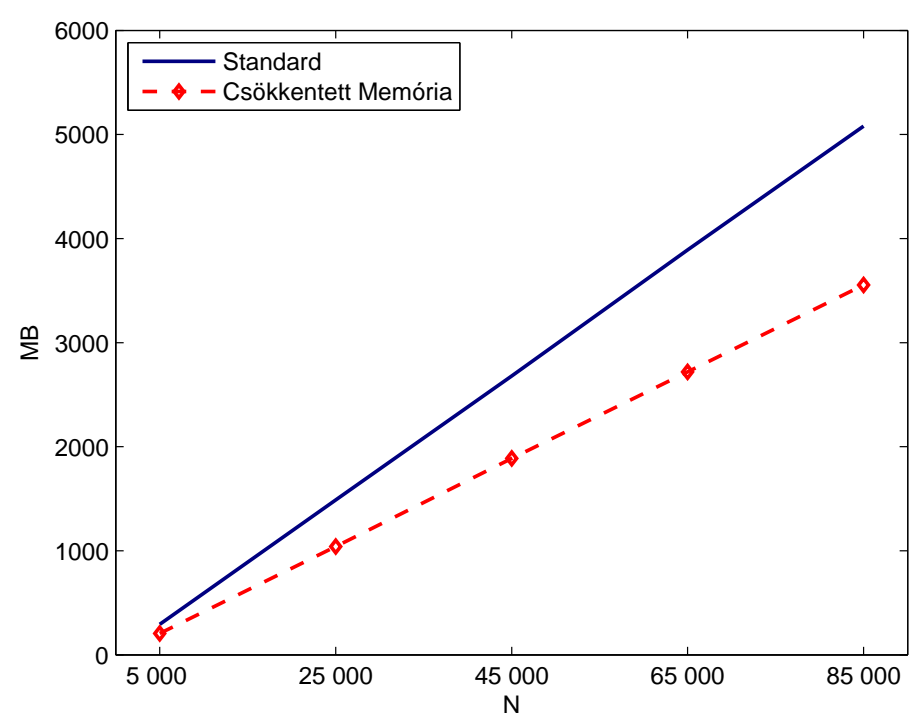

2.9. ábra. Futási idő a szimuláció során felhasznált utak függvényében

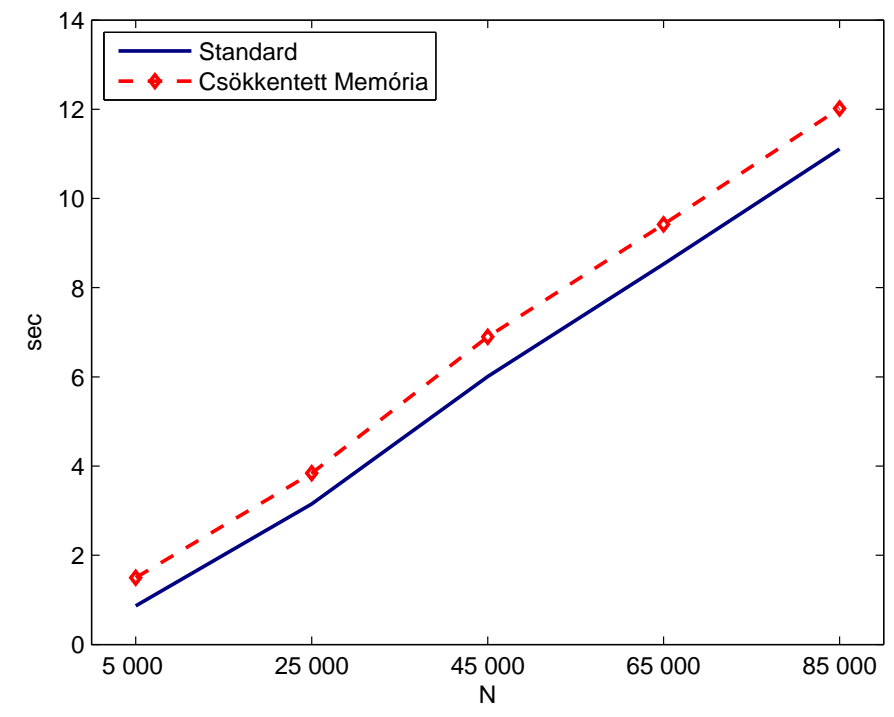

\subsubsection{Termékek korai lehívhatósággal}

Ebben a részben kiterjesztem a korábban definiált algoritmust korai lehívási opcióval rendelkező derivatív szerződésekre. A korai lehívási opció jelenléte megváltoztatja a pozíció pénzáramait, így a fő kihívást az $\hat{\Pi}\left(t_{i}, T\right)$ pénzáramok meghatározása jelenti. Elég csak az algoritmus 3. pontjára tekinteni, ahol eddig az $\hat{\Pi}\left(t_{m}, T\right)$ értékek rendelkezésre álltak, most azonban nem tudjuk, hogy egy adott úton a derivatív még életben van-e vagy esetleg már korábban lehívták. Joshi és Kwon (2016) kiegészített módszere szerint ezért a pénzáramokat ki kell igazítani a korai lehívási döntések szerint. Tudjuk, hogy a Longstaff-Schwartz eljárás eredeti célja 
korai lehívási opcióval rendelkező termékek árazása volt, így ez a módszer ideális jelöltnek számít a kiigazított pénzáramok meghatározására. Kövessük tehát Joshi és Kwon (2016) kiegészített módszerét, amely szerint a lejárattól indulva a Longstaff-Schwartz eljárással minden úton megadjuk a korai lehívási döntést, és az azutáni időpontokra töröljük a pénzáramokat.

Így meghatározhatjuk a $\hat{\Pi}\left(t_{i}, T\right), i=m, m-1, \ldots, 0$ mátrixot. Láthatjuk, hogy a késleltetett fedezetet és a csökkentett memória felhasználást magába foglaló algoritmus ugyanúgy múködni fog, ha a korai megállítással kiigazított pénzáramok értékét, mint egy inputot megadjuk neki. Emiatt elég az algoritmus egy apróbb módosítását elvégezni, és így a pénzáramokat meghatározó Longstaff-Schwartz módszert beilleszteni az eljárás elejére. Vegyük észre azonban, hogy minden útra és időpontra a $\hat{\Pi}\left(t_{i}, T\right)$ értékek átadása jelentősen megterhelheti a rendelkezésre álló memóriakapacitást. Ezt a problémát egyszerúen feloldhatjuk, ha a teljes pénzáram mátrix helyett, csupán a lehívás idôpontját adjuk át az algoritmusnak. Most fogalmazzuk meg a kiegészítést formálisan is:

\section{Első Futtatás - Regressziós becslés}

1. Adjuk meg a felhasznált utak számát $(N)$, az időfelosztást $\left(0=t_{0}<t_{1}<\right.$ $\left.<. .<t_{m}=T\right)$ és a bázisfüggvényeket $\left(\xi_{., j}, \mathrm{j}=1, \ldots \mathrm{k}\right)$.

2. Szimuláljuk az alapfaktorok $N$ számú útját a $0=t_{0}<t_{1}<. .<t_{m}=$ $=T$ időfelosztáson időben előrehaladva, miközben minden $t_{i}, i=1, \ldots, m$ idôponthoz történô véletlenszám generálás elôtt elmentjük a véletlenszám generátor állapotát, és csakis az alapfaktorok legutóbbi értékét tároljuk a memóriában.

3. Végezzünk el a korai lehívás becslését Longstaff-Schwartz módszerével az alábbi lépéseket követve ${ }^{25}$

a) Jelölje $\xi_{., j}^{\prime}, j=1, \ldots k^{\prime}$ a bázisfüggvényeket. Határozzuk meg a lejáratkori pénzáramokat $\left(\hat{\Pi}^{\prime}\left(t_{m}, T\right)\right)$, feltételezve, hogy egyik úton sem történt lehívás.

b) Határozzuk meg az alapfaktorok elôző pontbeli értékét a következóképpen: Állítsuk a véletlenszám generátor állapotát a legutóbb elmentett értékre, és generáljuk le újra a korábban már szimulált véletlenszámokat. Használjuk fel az alapfaktorok jelenlegi állapotát, az idóben

${ }^{25}$ Ennél a pontnál feltételezzük, hogy a termék bármelyik időpontban lehívható. (Amerikai opció jelleg) Valójában az algoritmus ugyanúgy használható Bermuda típusú opciók esetében is, ahol csak bizonyos véges idôpontban engedélyezzük a lehívást. Értelemszerűen ilyenkor a regresszió illesztését és a korai lehívási döntés ellenôrzését csak ezekben az időpontokban végezzük el. 
hátrahaladó diszkretizált differenciálegyenlet alakot és az újonnan szimulált véletlenszámokat az alapfaktorok egy lépéssel korábbi értékeinek kiszámítására. Végül értékeljük ki a bázisfüggvényeket $\left(\xi_{m-1, j}^{\prime}, \mathrm{j}\right.$ $=1, \ldots$ k') az alapfaktorok alapján.

c) Végezzük el a regresszió illesztését a 2.53 . egyenlet $\beta_{m-1, j}^{\prime}, j=1, \ldots, k^{\prime}$ változók szerinti minimalizálásával:

$$
\sum_{\omega}\left[\sum_{j=1}^{k^{\prime}} \beta_{m-1, j}^{\prime} \xi_{m-1, j}^{\prime}(\omega)-\left(\Pi^{\prime}\right)^{\omega}\left(t_{m-1}, T\right)\right]^{2}
$$

ahol $\Pi^{\prime}\left(t_{m-1}, T\right)=D\left(t_{m-1}, t_{m}\right) \hat{\Pi}^{\prime}\left(t_{m}, T\right)$ minden úton. Mentsük el a regressziós együtthatókat, valamint határozzuk meg a korai lehívási döntést minden útra: Ha $Q$ vektorban tároljuk az összes útra a korai lehívási időpontot, akkor legyen $Q(h)=t_{i}$, ha $f_{i}(h) \leq L_{i}(h)$, ahol $f_{i}=\sum_{j=1}^{k^{\prime}} \beta_{i, j}^{\prime} \xi_{i, j}^{\prime}, L_{i}$ az azonnali lehívás értéke és $h=1, \ldots, N$. Határozzuk meg a $\hat{\Pi}^{\prime}\left(t_{m-1}, T\right)$ értékeket figyelembe véve az esetlegesen aktuális kifizetéseket és a lehívási döntést.

d) Ismételjük a (b) és (c) pontot általánosan az $m=k$ esetre, ahol $k=$ $=m-1, m-2, \ldots, 1$.

e) Állítsuk a rendszerünket a 2. pont utáni állapotba és figyelembe véve a megadott lehívási idôpontokat $(Q)$ állítsuk elő a lejáratkori pénzáramokat $\left(\hat{\Pi}\left(t_{m}, T\right)\right)$.

4. Határozzuk meg az alapfaktorok előző pontbeli értékét a 3(b) ponthoz hasonlóan és értékeljük ki a bázisfüggvényeket $\left(\xi_{m-1, j}, \mathrm{j}=1, \ldots \mathrm{k}\right)$ az alapfaktorok alapján.

5. Végezzük el a regresszió illesztését a 2.40 , egyenlet $\beta_{m-1, j}, j=1, \ldots, k$ változók szerinti minimalizálásával, ahol $\Pi\left(t_{m-1}, T\right)=D\left(t_{m-1}, t_{m}\right) \hat{\Pi}\left(t_{m}, T\right)$ minden úton. Mentsük el a regressziós együtthatókat és figyelembe véve a lehívási idôpontokat $(Q)$ valamint az aktuális kifizetéseket határozzuk meg az $\hat{\Pi}\left(t_{m-1}, T\right)$ értékeket.

6. Ismételjük a 4. és 5 . pontot általánosan az $m=k$ esetre, ahol $k=m-$ $-1, m-2, \ldots, 1$.

Ez első szakasz után rendelkezésre állnak a két regresszióhoz tartozó együtthatók sorozatai: az elsố sorozatot a korai lehívási döntéshez használjuk, míg a másodikat a hitelértékelési kiigazítás egyenletéhez. Alkalmazzuk ezeket egy független szimulációban: 


\section{Második Futtatás - Kiértékelés}

7. Szimuláljuk az alapfaktorok újabb $N$ számú útját a $0=t_{0}<t_{1}<$.. $<t_{m}=$ $=T$ időfelosztáson időben előrehaladva, miközben minden $t_{i}, i=1, \ldots, m$ időponthoz történő véletlenszám generálás előtt elmentjük a véletlenszám generátor állapotát, és csakis az alapfaktorok legutóbbi értékét tároljuk a memóriában. Továbbá minden idôpontban meghatározzuk a diszkontfaktorok $D\left(0, t_{i}\right)$ értékét, amelyekból mindig a legújabbat tároljuk el.

8. Meghatározzuk a korai lehívási döntés időpontját:

a) Az első futtatásban ismertetett eljáráshoz hasonló módon megadjuk az alapfaktorok egy ponttal korábbi értékét és kiértékeljük a bázisfüggvényeket $\left(\xi_{., j}^{\prime}, j=1, \ldots, k^{\prime}\right)$. A korai lehívási döntésre becsült regressziós paraméterek segítségével meghatározzuk a folytatási értéket, és azt az azonnali lehívás értékéhez hasonlítjuk. Minden lehívási döntés időpontját elmentjük a $Q$ vektorba.

b) Ismételjük a fenti eljárást, amíg a kiindulási pontig érünk.

c) Visszaállítjuk a rendszert a 7. pont utáni helyzetbe.

9. Idôben hátulról haladva az újabb utakon is megadjuk a pénzáramok diszkontált értékét $\left(\Pi\left(t_{m-1}, T\right)=D\left(t_{m-1}, t_{m}\right) \hat{\Pi}\left(t_{m}, T\right)\right)$, valamint az előzô időponthoz tartozó alapfaktorokat és a bázisfüggvények értékeit. A pénzáramok meghatározásánál figyelembe vesszük a lehívási döntések idejét $(Q)$. A korábban becsült regressziós egyenlet segítségével megbecsüljük a 2.39 . egyenletben adott $f_{m-1}$ értékét. Az $f_{m-1} \approx V_{m-1}$ közelítést felhasználva megadjuk a $K_{m-1+\delta}=C_{m-1}=f_{m-1}$ fedezeti számla értékét. Mivel ekkor a $D\left(0, t_{m}\right)$ és az alapfaktorok $t_{m-1}$ idốpontbeli értékei rendelkezésre állnak, így $D\left(0, t_{m-1}\right)$ is meghatározható. Ekkor figyelembe véve, hogy a fedezet késéssel történô visszaszolgáltatása miatt még a lejárat után is lehet kitettségünk, megbecsüljük a 2.45. egyenlet alábbi módosított alakjának utolsó tagját:

$$
C V A \approx \sum_{i=1}^{m-1+\delta} L G D \mathbb{Q}_{t}\left(t_{i-1}<\tau \leq t_{i}\right) \mathbb{E}_{0}\left[D\left(0, t_{i}\right)\left(\Pi\left(t_{i}, T\right)-K_{i}\right) 1_{\left(f_{i}-K_{i}>0\right)}\right]
$$

ahol $f_{i}=\Pi\left(t_{i}, T\right)=0$, minden $i \geq m$ esetén.

10. Időben visszalépve ismételjük az előző pontbeli eljárást, és a 2.54. egyenlet minden tagját megbecsüljük, feltételezve, hogy $K_{i}=0, i=1, \ldots, \delta$.

A kiterjesztett algoritmust egy numerikus példán tesztelem. Az elôző fejezetben ismertetett eredményeket részben újrafelhasználva most egy felmondható 
kamatláb csereügyleten szemléltetem a módszer hatékonyságát. A felmondható kamatláb csereügylet kifizetései lényegében megegyeznek egy egyszerú kamatláb csereügylet kifizetéseivel, azonban a felmondhatósági opcióval rendelkező félnek az ügylet lejáratáig előre meghatározott időpontokban egy bizonyos költségért cserében joga van elállni a szerzôdéstôl, és zárni a pozíciót. Ez az egyszerú módosítás jelentôsen megnehezíti a termék árazását és a hitelértékelési kiigazítás számítását. Ebben az esetben a termék már nem árazható analitikusan, ezért már a kitettség profil számításához is a Longstaff-Schwartz módszerre van szükség.

A példában a kitettséget számoló félnek joga van az 5. évtől kezdve félévente felmondani a pozíciót. Jelen helyzetben ingyenes elállási lehetőséget tételeztem fel, de az opció értékét a csereügylet fix lábába építettem be. A becsléshez $N=$ $=100000$ utat és 100 futtatást használtam. Az így kapott kitettség profilt a 2.10. ábrán ismertetem. Az elôzô példához képest a legszembetûnőbb változás a profil kiugrásainak eltûnése az 5. évtól kezdve. Ennek a megértéséhez célszerú az opció tulajdonosa szempontjából megvizsgálni az ügyletet: nagyon negatív értékú szcenáriókon most jogunk van zárni az ügyletet, amellyel párhuzamosan megszúnik a letét szolgáltatási kötelezettség. Ennélfogva az átadott letét nem képes felhalmozódni. Így nem történhet meg a korábban megfigyelt tüskéket generáló jelenség, azaz, hogy egy-egy fizetési napon a negatív tartományon a csereügylet értéke nagyon eltávolodik a fedezet rendelkezésre álló mennyiségétól.

2.10. ábra. Felmondható kamatláb csereügylet várható kitettség profilja késleltetett fedezettel

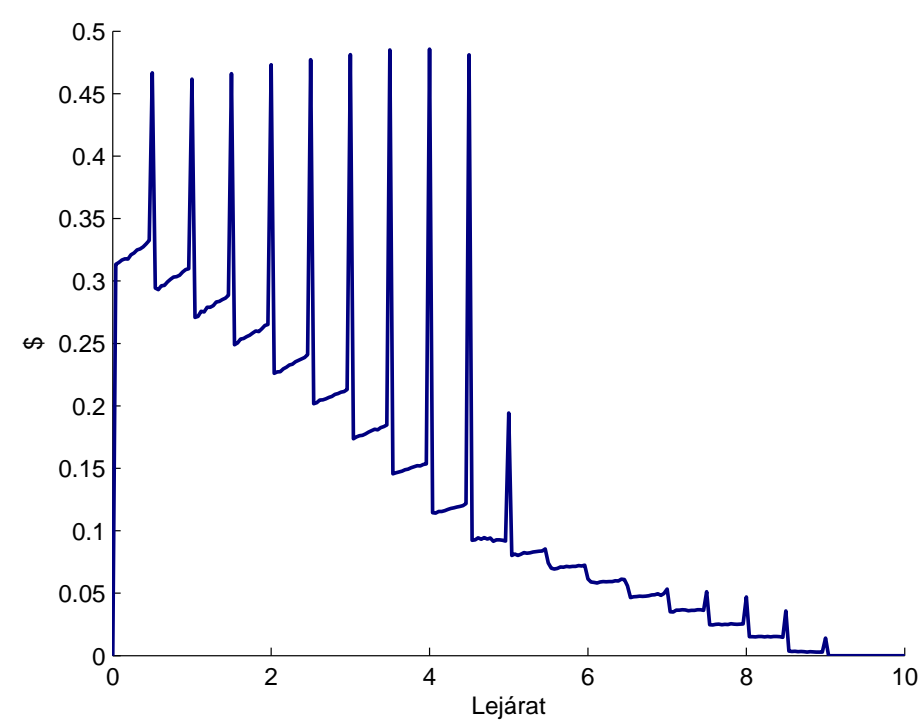

Analitikus formula hiányában, a CVA értékeit a csökkentett memória igényú algoritmus szerint számoltam. Az eredményeket a 2.5. táblázatban közöltem.

Hasonlóan az előző példához, most is megmértem a standard és a csökkentett 
2.5. táblázat. A felmondható kamatláb csereügylet hitelértékelési kiigazításának 100 futtatás alapján becsült értékei

\begin{tabular}{|c|c|c|c|c|c|}
\hline & \multicolumn{5}{|c|}{ Regressziós eljárás } \\
\hline $\mathrm{N}$ & 5000 & 25000 & 45000 & 65000 & 85000 \\
\hline CVA & 0.03189 & 0.03130 & 0.03129 & 0.03116 & 0.03126 \\
\hline Standard hiba & $4.34 \mathrm{E}-04$ & $1.87 \mathrm{E}-04$ & $1.39 \mathrm{E}-04$ & $1.04 \mathrm{E}-04$ & $0.97 \mathrm{E}-04$ \\
\hline
\end{tabular}

memóriaigényú algoritmus maximális memória felhasználását és a futási idejét. A 2.11. ábrán a memóriaszükségletet elemzem. A két módszer közötti különbség hasonló képet mutat: a fentebb kifejtett algoritmussal valamelyest 30 százalék feletti memóriacsökkentés érhetô el. Ugyan fontos kiemelni, hogy a korai lehívási döntés becslése miatt mindkét eljárás memóriaigénye nôtt.

2.11. ábra. Memóriaszükséglet a szimuláció során felhasznált utak függvényében egy felmondható kamatláb csereügylet esetén

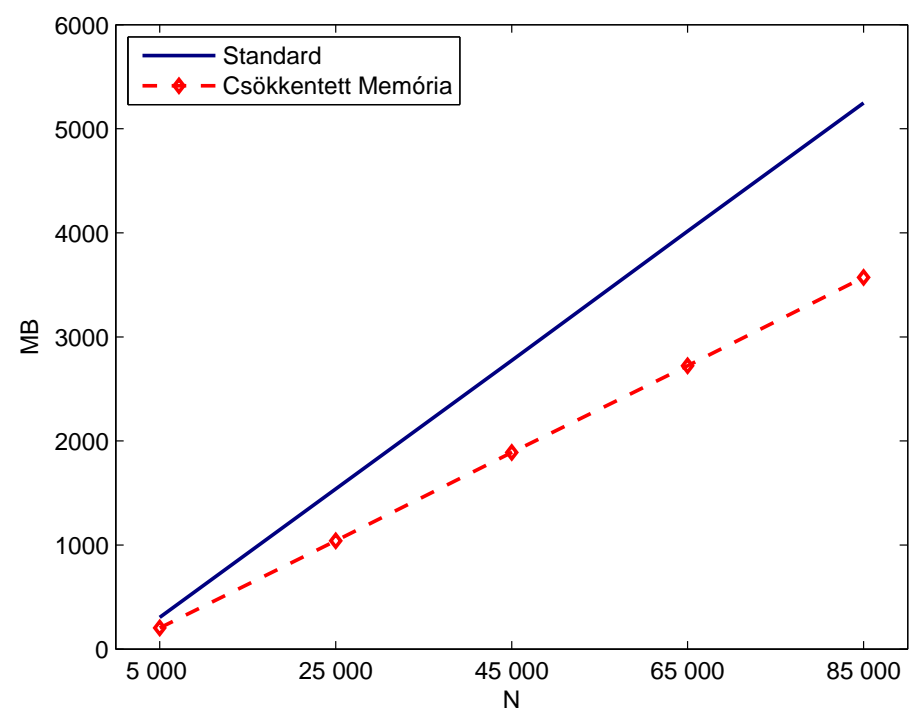

Az előzőekhez hasonló képet kapunk, ha a futáshoz szükséges idôt elemezzük a 2.12, ábrán, de két fontos különbséget ki kell emelnünk. Elsóként, a LongstaffSchwartz eljárás bevezetése közel 25 százalékkal növeli mindkét algoritmus futási idejét. A növekedés összhangban van az elvártakkal, hiszen a korai lehívási döntés meghatározása egy új lépés az algoritmusban. A második megfigyelés a két eljárás különbségére fókuszál. A csökkentett memóriaigényú eljárás ismét rosszabbul teljesít, mitöbb a két eljárás közötti idő különbség megnövekedett. A távolodást a futási időben az alapfaktorok többszöri újraszimulálása okozza. A fentebb leírt algoritmusban ugyanis minden alapfaktor utat háromszor állítunk elő: Először az előrehaladó szimulációkor, másodszor a Longstaff-Schwartz eljárás során, míg vé- 
gül a CVA egyenletét becslő LSMC módszernél. Korábban, a Longstaff-Schwartz eljárás hiányában csupán kétszer kellett az alapfaktorokat szimulálni. Ez a változás tehát tovább növeli a csökkentett memóriaigényú algoritmus futási idejét, azonban a ráadás idôtartam még mindig alacsonynak tekinthető, különösen ha a szcenáriók számát emeljük.

2.12. ábra. Futási idő a szimuláció során felhasznált utak függvényében egy felmondható kamatláb csereügylet esetén

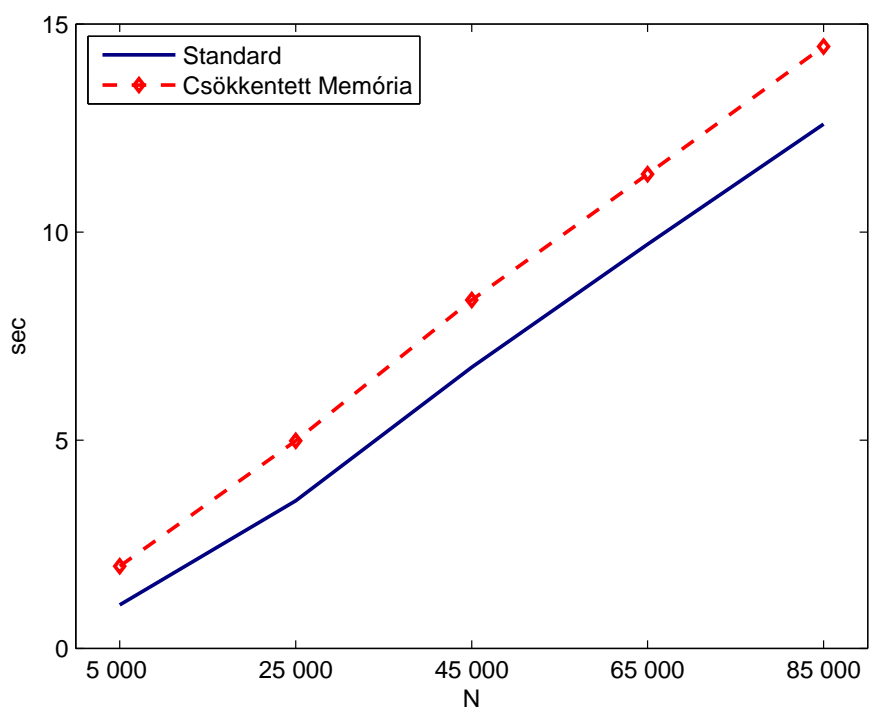

\section{3. Összefoglalás}

A fejezetben a partnerkockázat mérésének technikai eszközeivel foglalkoztam. Ebben a részben az 1. fejezetben ismertetett formulák hatékony számszerúsítésére helyeztem a hangsúlyt, miközben egy specifikus szemszögból történô vizsgálatot végeztem el. Így a kitettség és a hitelértékelési kiigazítás formális leírását összekapcsoltam az azok meghatározására használható numerikus módszerek fejlesztésével.

Először egy új eljárást építettem a többszintú Monte Carlo becslés felhasználásával, amit a partnerkockázat egyik alapproblémájára, a kitettség meghatározására alkalmaztam. Az általam javasolt módszer felülmúlja a hagyományos Monte Carlo becslést, hiszen mind a számítási kapacitást, mind pedig a futási idôt csökkentetni tudtam. Nagy előnye a technika egyszerúsége is, amely a hatékony implementációhoz járul hozzá. Az alfejezetben bemutatott megközelítés egy speciális többszintú Monte Carlo technikán alapul, amely azonban csupán limitált számú esetben használható. Mivel nem használtam a szimulált alapfaktorok teljes útját, így a módszer csak egzakt szimuláció mellett alkalmazható. Az algoritmus limitált jellege azonban nem gátolja a technika széleskörú alkalmazá- 
sát, hiszen számos modellre létezik egzakt szimuláció. Így hasznos kutatási téma lehet a módszer további vizsgálata és más eszköz típusokra történő alkalmazása. Ugyan itt csak a várható kitettség profil becslését teszteltem, a többszintú Monte Carlo becslés hasonlóan alkalmazható más profilok becslésére is. Ezek további vizsgálata gyakorlati szempontból is nagy relevanciával bír.

Ezután komplexebb termékek hitelértékelési kiigazításának meghatározásával foglalkoztam. Az Amerikai Monte Carlo módszerek széles körben felhasznált, nagy teljesítményú eljárásmódnak számítanak a partnerkockázat területén. Bizonyos formában szinte megkerülhetetlen eszköztárat képeznek változatos opciós jelleggel rendelkező derivatív szerződések kitettség profiljának meghatározására. A technika által lefedett szerzôdéskör könnyen bôvíthető, ha a testre szabható letéti megállapodások pénzáram módosító hatásait is figyelembe vesszük. Az átfogó felhasználási kör különösen fontos a hitelértékelési kiigazítás meghatározásakor is.

A fejezetben a fedezet természetes késését is magába foglaló AMC alapú eljárást javasoltam a hitelértékelési kiigazítás számítására. Az így kapott kiegészített LSMC eljárás egyik nagy hátránya a memória felhasználás jelentős növekedése. A megnövelt memória igény azonban a pontosság csökkenéséhez vezethet, ha a felhasználó nem rendelkezik jelentős memóriakapacitással. Így az alfejezet második célja ennek a korlátnak az enyhítése volt. Egy, az amerikai opciók árazására bevezetett technikát ültettem át a kockázatkezelés világába, amellyel sikeresen csökkentettem a módszer memóriaigényét anélkül, hogy jelentősen növeltem volna a futási időt.

A késleltetett letét modellezésének alapjainak ismertetése után, korai lehívási opcióval rendelkezó és anélküli termékekre is megadtam a hitelértékelési kiigazítást számító, csökkentett memóriaigényû algoritmust. Ezután két gyakori derivatív szerződésen mutattam be annak felhasználását. Számpéldáim azt mutatják, hogy az alapfaktorok újraszimulálása és a korai lehívási döntés algoritmuson belül történô átadása a memória felhasználás 30 százalékos csökkenéséhez vezet.

A fejezet a hitelértékelési kiigazítás kitettség komponensére fókuszált. A következố részben a hangsúlyt a CVA másik fô komponensére, a csődvalószínúségek becslésére helyezem és a csôdvalószínûségeket egy alternatív szempontból elemzem. Megvizsgálom, hogy a csődesemények modellezése során van-e relevanciája a hitelminősítések közötti átmenetek fertőző hatásainak, valamint hogy azok befolyásolják-e a hitelértékelési kiigazítás értékét. 


\section{3. fejezet}

\section{A hitelminôsítôi bejelentések fertôző hatásai és a hitelértékelési kiigazítás}

Az 1. fejezetben bemutattam a csődmodellezés alapjait. A CVA bemutatásakor világossá vált, hogy a csốdidôpont és csôdvalószínúségek jelentős szerepet kapnak a partnerkockázat árazásában, így azok pontos mérése elengedhetetlen feladat. Az 1. fejezetben azonban a partnerre, mint egy egyedülálló entitásra tekintettem, holott a gyakorlatban a piacon lévô vállalatok számos csatornán keresztül hatást gyakorolnak egymásra. Ennélfogva a csődesemények közötti kapcsolat figyelmen kívül hagyása komoly hibát hordozhat magában, ami miatt a csődesemények korrelációjának vizsgálata fontos kutatási területté vált. A csődesemények korrelációjának a partnerkockázatra és a hitelértékelési kiigazításra gyakorolt hatását már számos tanulmány elemezte, köztük Hull és White (2000), Schönbucher és Schubert (2001) vagy Brigo és Chourdakis (2009).

A fertőzô csődesemények, amely fogalom Davis és Lo (2001) és Jarrow és Yu (2001) munkáihoz köthetô, egy alternatív megközelítésmódot kínálnak a csődesemények korrelációjának modellezésére. Ezekben a modellekben az egyes vállalatok csődeseményei befolyásolják a túlélő vállalatok csődintenzitás folyamatait, így közvetve azok csődeseményeit. Jellemzően egy csődesemény növeli a túlélő fél intenzitás folyamatát, így tükrözve a fertôzés terjedését a piacon. Ez a specifikáció azonban az úgynevezett körkörös csődesemények problémáját okozza, amely azt jelenti, hogy az összefüggó intenzitás folyamatok már nem szimulálhatóak egymástól függetlenül.

Jarrow és Yu (2001) munkája óta számos megoldás született a körkörös csôdesemények problémájára. Yu (2007) úgynevezett teljes hazard építési eljárása egy általános algoritmust ad a rekurzív probléma leküzdésére. Leung és Kwok (2005) munkája a túlélési mérték fogalmára építve oldja fel a szimulálási nehéz- 
ségeket. Speciális esetekben Walker (2006) és Leung és Kwok (2009) Markov-lánc alapú megoldása is használható.

Empirikus elemzések azonban rámutattak, hogy a csődesemények mellett a hitelminôsítési változások is járhatnak fertôzô hatásokkal. Wengner et al. (2015) azt vizsgálták, hogy van-e hatása egy vállalatot érintô hitelminôsítői bejelentésnek a vállalat versenytársainak CDS felárára. Eredményeik szerint az úgynevezett nem érintett vállalatok hitelfelára csökken (nô) a társuk leminősítésekor (felminôsítésekor), ami arra mutat rá, hogy egy hitelminősítési változás hatása ellentétes egy csődesemény után tapasztalthoz képest. Ezenfelül Micu et al. (2006), Finnerty et al. (2013). Wengner et al. (2015) tanulmányai mind arra a következtetésre jutnak, hogy a le- vagy a felminôsítés az érintett vállalat CDS felárát is befolyásolja : a hitelfelár jellemzően emelkedik (csökken) egy leminősítés (felminôsítés) bejelentésekor, vagy azt megelôzốn. A hitelminôsítői bejelentések hatását a szakirodalom elhanyagolja a hitelértékelési kiigazítás modellezésekor, miközben a hitelfelárak annak fontos bemeneti paraméterei. Jelen fejezetben bevezetek egy kiterjesztett keretrendszert, ami beépíti az empirikus eredményeket a CVA modellezéséhez gyakran használt redukált formájú modellbe.

A fejezet célja, hogy felmérje a hitelminősítő intézmények bejelentéseinek a hitelértékelési kiigazításra gyakorolt hatását, felhasználva a fertőző csődesemények keretrendszerét. Így megvizsgálom a legújabb empirikus kutatási eredményeket, és beépítem azokat a redukált formájú modellkeretbe. A modell a körkörös csôdesemények problémájának egy általánosítását örökli, amely megoldásához egy új módszerre van szükség. Ezért kiterjesztem a teljes hazard építési eljárást, ami lehetôvé teszi a rekurzív probléma feloldását és a modell tesztelését. Az eredményeim azt mutatják, hogy a hitelminôsítôi bejelentések után fellépô fertôző hatások jelentôsen megváltoztathatják a hitelértékelési kiigazítás értékét olyan esetekben, amikor az iparág vállalatainak hitelminôsítése erôsen koncentrálódik a spektrum egyik végén. Ez a megfigyelés egy-, de különösen kétoldalú hitelértékelési kiigazítás mellet igaz, még akkor is, ha a feleknek fedezet is rendelkezésre áll. Másrészt viszont, egyenletesebb eloszlású iparágakban a fertôzés hatása elhanyagolható. Eredményeim mögött a hitelbesorolás változások kétoldalú jellege húzódik meg, amely miatt két változás hatása gyakran kioltja egymást.

A következô részben ismertetem a szakirodalom empirikus kutatásokon alapuló eredményeit. Ezután a teljesség kedvéért felidézem a hitelértékelési kiigazítás legfontosabb fogalmait. A 3.3 , alfejezetben bevezetem a modellt, amely figyelembe veszi a hitelminôsítôi intézmények bejelentéseinek fertőző hatásait. Mivel a modell megoldása egy új eljárást kíván, ezért itt megadok egy algoritmust, amellyel már szimulálhatóak a csődesemények. A 3.4. alfejezetben egy numerikus példán szemléltetem a modellt. Végül a fejezetet egy összefoglalással zárom. 


\subsection{A hitelminősítői bejelentések és a csődesemé- nyek hatása}

A hitelminôsítő intézmények a pénzügyi piacok fontos szereplői. Az ô feladatuk a befektetők döntéseit befolyásoló információs aszimmetria mérséklése azáltal, hogy az egyes piaci szereplőket hitelminôsítési kategóriákba osztják be. Emiatt egy hitelminősítő bejelentésnek friss információt kell hordoznia, ami várhatóan befolyásolja a piaci faktorokat vagy más piaci szereplóket. Ezzel szemben, a hitelminősítő intézmények igyekeznek minimalizálni a bejelentéseik számát annak érdekében, hogy a hitelminősítések volatilitását csökkentsék. E célból, egy adott vállalat hitelminőségét érintő esemény után gyakran kivárnak a bejelentéssel, hogy megbizonyosodjanak az esemény hatásának tartósságáról.

Számos tanulmány foglalkozik annak az elemzésével, hogy a hitelminősítési besorolás megváltozása hogyan hat a hitelfelárra. Míg a korai munkák (például Weinstein (1977), Hite és Warga (1997), Steiner és Heinke (2001)) a vállalati kötvények által implikált felárat használták, az újabb tanulmányok a hitelmulasztási ügyletek felárait használják a hitelminôsítô bejelentések és a hitelfelár kapcsolatának a meghatározására. Hull et al. (2004) azt a következtetést vonják le, hogy a le- és felminôsítések információtartalma elhanyagolható, mivel a piacok már a bejelentési nap előtt reagálnak. A Moody's hitelminősítési adatai alapján azt találják, hogy a CDS felárak már a bejelentés előtt tükrözik annak hatását, és a nyilvánosságra hozatal napján sem fel- sem pedig leminôsítés esetén nem változnak szignifikánsan. Ezzel szemben a hitelminősítő közleménye egy adott vállalat leminősítési felülvizsgálatának megkezdésérôl (review of downgrade) szignifikáns változásokat okoz a hitelfelárban.

Norden és Weber (2004) már mindhárom nagy hitelminősítô intézményre kiterjesztik az elemzést. Fô eredményük, hogy a Moody's és S\&P leminôsítések a hitelfelárak szignifikáns változását okozzák a bejelentés előtt és - Hull et al. (2004) munkájával ellentétben - a bejelentés napján is. A Fitch közleményei sokkal gyengébb, nem szignifikáns hatást mutatnak. Micu et al. 2006) 2001 és 2006 közötti adatokra építik hasonló, esemény ablak technikájú elemzésüket, amelyben mindhárom nagy hitelminősítő intézmény besorolásait és CDS felárakat használnak. A tanulmányukban a napi felár változások arányát is vizsgálják, szemben a korábbi munkákkal, amelyek csak a felárak különbségére épültek. A szerzők azt a konklúziót vonják le, hogy minden típusú hitelesemény (hitelminőség változtatás, le- vagy felminősítési felülvizsgálat megkezdése és kilátások változtatása) szignifikáns hatással jár a CDS felárakra a bejelentés napján, így az releváns információt hordoz.

Egy valamelyest frissebb tanulmányban Finnerty et al. (2013) azt találják, 
hogy az S\&P felminősítésekre valamint a felülvizsgálati bejelentésekre a piaci szereplők kevésbé számítanak, mint a leminősítésekre. Különösképpen, alacsony minősítésú vállalatok felminősítése nagyobb meglepetésnek számít, mint a jobb minôsítésból induló vállalatoké. Ezekben az esetekben ugyanis az aznapi hatás szignifikáns, szemben a megelőzố napokon becsült értékkel. Ezenfelül Finnerty et al. (2013) azt is kimutatják, hogy a negatív bejelentéseknek nagyobb a hatása, mint a pozitív közleményeknek.

Bár a szakirodalom nem egységes ebben a témában, de ahogy azt a fentiek alapján láthatjuk, számos tanulmány arra a következtetésre jut, hogy egy vállalat leminősítése (felminősítése) növeli (csökkenti) annak CDS felárát. Ami azt illeti, a fentebb felsorakoztatott munkák csak azzal a vállalattal (érintett vállalat) foglalkoznak, amelyre a hitelminősítői bejelentés vonatkozik és figyelmen kívül hagyják annak társait (nem érintett vállalat). Valójában ésszerú azt feltételezni, hogy egy vállalat hitelbesorolásának megváltozása kihat a partnerei felárára $\left.\right|^{1}$ Továbbá, hasonlóan logikus lehet kiterjeszteni a vizsgálatot az érintett vállalat versenytársaira. Egy iparág jelentôs szereplőjének a leminôsítése megnövelheti a versenytársak piaci részesedését, így javítva azok hitelminôségét, avagy éppen növelheti azok kockázatát a piacon fellépő lehetséges fertôzés miatt.

Wengner et al. (2015) az elsők, akik a hitelminősítő intézmények bejelentéseit követő tovagyưrưző hatásokat vizsgálják. 2004 és 2011 közötti S\&P bejelentéseket és CDS felárakat vizsgálva azt találják, hogy mind az érintett és a nem érintett vállalatok CDS felárai egyaránt szignifikánsan változnak a hitelminôsítôi bejelentések körül. Megfigyelésük szerint egy vállalat leminősítése csökkenti az iparágban tevékenykedô versenytársak CDS felárát, azaz azok hasznot húznak a társukat érintő negatív eseményből. Ezzel szemben, felminősítés esetén a nem érintett vállalatok hitelfelára növekedni fog. Az érintett vállalatok esetében a felár mindig szignifikánsan változik, de a változás mértéke függ az iparágtól. Végül egy panel regressziót becsülve rámutatnak, hogy a tovagyưrúzô hatás nagysága függ a nem érintett vállalat hitelbesorolásától, ugyanis az alacsonyabb hitelminôségú vállalatok érzékenyebbek a fertôzésre kevésbé kockázatos társaikhoz képest.

Ezek az eredmények azt az érzetet kelthetik, hogy egy versenytárs hitelminôségének a romlása mindig a vállalat helyzetének a javulását okozza. Ennek tévességére mutat rá a Lehman Brothers 2008-as csődeseménye. Egy versenytárs lehetséges csődje veszélybe sodorhatja a túlélő felet, például a felé fennálló követeléseken elszenvedett veszteségek miatt. A magas szintú összekapcsoltság - ami például a pénzügyi szektort jellemzi - segíti a fertôzô hatások gyors terjedését.

${ }^{1}$ A letéti megállapodások (CSA) gyakran tartalmaznak hitelminôsítéshez kötött rendkívüli pontokat, amelyek megváltoztathatják a letéti követelményeket. Így például egy leminôsítés további letéti követelményekkel járhat, amely mindkét vállalat likviditását érintheti. 
Ezt a hipotézist erôsítik meg Jorion és Zhang (2009), akik a csődbe menô vállalatok hitelezôinek felárait vizsgálták meg. Eredményeik szerint a csődidôpontot megelőzően és még jelentős idôvel késôbb is a túlélő felek CDS feláraiban bekövetkező növekedés szignifikáns. Ez azt jelenti, hogy a csődesemény a nem érintett vállalatokra vonatkozó hatása a leminôsítéssel ellentétes.

Így a csốdesemények korrelációjának a modellezése releváns kutatási téma. Ahogy a bevezetőben kifejtettem, Jarrow és Yu (2001) a fertôzô csődesemények modellezését vezetik be a redukált formájú modellekbe. Fô érvük, hogy egy vállalat csődeseménye után a piaci fertôzés a túlélố vállalatok megemelkedett csốdintenzitás folyamataiban számszerûsíthetô.

Ez a megoldás azt feltételezi, hogy a vállalatok intenzitás folyamatai konstansok (hazard ráta), de egy piaci szereplő csődidőpontja után azok egy új konstans szintre kerülnek. Ez az egyszerú keretrendszer az implementálás kihívását okozza, ugyanis az intenzitás folyamatok szimulálása nehézkessé válik. A körkörös csődesemények modelljében az intenzitás folyamatok egymástól függenek, így azok már nem szimulálhatóak függetlenül. Jarrow és Yu (2001) megkerülik ezt a problémát azzal a feltételezéssel, hogy a vállalatok vagy elsôdleges vagy másodlagos kategóriákba sorolhatóak. A második kategóriába a kisebb cégek kerülnek, amelyekre kihathat az elsố csoportban szereplő, nagyobb vállalatok csődeseménye, de ez a kapcsolat fordítva nem igaz.

A körkörös csődesemények problémáját jelentős figyelem övezte, amely a probléma számos megoldását eredményezte. Leung és Kwok (2005) a túlélési mértéket használják, míg Walker (2006) és Leung és Kwok (2009) Markov-lánc alapú megoldással álltak elő. A körkörös csődesemények problémájának teljes hazard építés alapú megoldását hat évvel a probléma felvetése után Yu (2007) készítette el. Az általa bevezetett algoritmust követve, lépésról lépésre egy kumulált intenzitás folyamat építhető, amellyel minden pillanatban eldönthető, hogy bármelyik vállalat csôdeseménye bekövetkezett-e. A módszer széleskörüen alkalmazható csődintenzitás folyamatok számos családjára, de a hitelminôsítési besorolás változását nem veszi figyelembe. A következô alfejezetben úgy egészítem ki az eljárást, hogy a hitelminősítô vállalatok bejelentéseire is érzékeny legyen.

Ugyanakkor a korai munkák után számos függóségi struktúra jelent meg a szakirodalomban. Bao et al. (2012) a túlélő fél intenzitás folyamatára a nemteljesítő fél csődidôpontja előtti intenzitás folyamatával arányos ugrást vezetnek be. Azaz Bao et al. (2012) azt feltételezik, hogy a nemteljesítő vállalat átruházza a csőd előtti intenzitásának egy részét a túlélő félnek.

Zheng (2013) egy általános keretrendszert ad, ahol figyelembe veszi a Cox folyamatok korrelációját, és a csődesemény utáni ugrásokat az intenzitás folyamatban. Ebben a modellben a Markov-lánc típusú keret már nem alkalmazható, 
mivel Zheng (2013) egy exponenciális csökkenést használ a múltbeli hatások enyhítésére.

A hitelbesorolások fontos szerepet játszanak a hitelértékelési kiigazítás számításakor is. Korábbi munkák már figyelembe vették a hitelminősítési kategóriától függő fedezet vagy a feltételes pozíciózárás hatásait. Így például Bielecki et al. (2013) egy általános modellkeretet építenek a hitelbesorolási kategóriától függố és változó letéttel ellátott derivatívák CVA számítására. A feltételes pozíciózárás hatását Yi (2011) elemzi. Tanulmánya szerint az egyoldalú hitelértékelési kiigazítás értéke csökken a hitelbesorolástól függố pozíciózárás bevezetésével, azonban a kétoldalú hitelértékelési kiigazítás akár nőhet is. Ismereteim szerint a hitelminősítői intézmények bejelentéseit követő piaci fertőzés partnerkockázatra gyakorolt hatását eddig nem vizsgálták a szakirodalomban. A CVA minél pontosabb számszerúsítése egy rendkívül fontos feladat. Releváns kockázati faktorok figyelmen kívül hagyása veszélyezteti a bankok teljesítóképességét, hiszen nem várt veszteségekhez vezethetnek. Továbbá ilyen faktorok rendszer szinten fedezés nélkül maradhatnak, kihatva a teljes bankrendszerre. A fejezetben megvizsgálom, hogy a hitelbesorolások közötti átmenetekkor fellépő fertôző hatások valóban befolyásolják-e a hitelértékelési kiigazítás értékét.

A következő részben egy hitelbesorolás alapú modellt vezetek be, amelyben a hitelminősítôi változtatás kihat a piacon jelenlévő összes vállalatra. Mivel a fejezet fô célja, hogy megvizsgálja a fertôzô hitelminôsítôi változások hatását hitelértékelési kiigazításra, ezért most a CVA árazó formula felidézésével folytatom, kiegészítve azt változó letét figyelembevételével.

\subsection{A hitelértékelési kiigazítás}

Ebben a fejezetben röviden ismertetem a fedezeti megállapodással kiegészített származtatott termékekre vonatkozó kétoldalú hitelértékelési kiigazítás számítását. A fejezetben leírt eredmények speciális esetenként az egyoldalú CVA is megadható. Részletes leírásért a bevezetô fejezetre utalok.

Elevenítsük fel az 1. fejezetet és a CVA formalizált leírását. Így dogozzunk egy $(\Omega, \mathcal{G}, \mathbb{G}, \mathbb{Q})$ valószínúségi mezőn, ahol $\mathbb{G}$ tartalmazza a teljes piaci információt és $\mathbb{Q}$ a kockázatsemleges mérték. Feltételezzük, hogy $\mathcal{G}_{t}=\mathcal{F}_{t} \cup \mathcal{H}_{t}$ ahol $\mathcal{F}_{t}=\sigma\left(X_{s}, 0 \leq s \leq t\right)$ az $X_{t}$ piaci faktorokat tartalmazó vektor által generált szigma algebra és $\mathcal{H}_{t}$ tartalmazza a csődeseményekre vonatkozó információt. Továbbá tételezzük fel, hogy két fél (B és $\mathrm{C}$ ) egy $T$ lejáratú derivatív szerződést kötnek. Jelölje $\Pi(t, T)$ a derivatíva t és T közötti kockázatmentes pénzáramainak $t$. időpontra diszkontált értékeinek az összegét. A származtatott termék partner- 
kockázat mentes ára $B$ szemszögéból:

$$
V_{t}=\mathbb{E}_{t}[\Pi(t, T)]
$$

ahol $\mathbb{E}_{t}[$.$] a Q$ mérték alatt számolt $\mathcal{F}_{t}$ feltételes várható érték.

Most vezessük be a modellbe a partnerkockázatot, feltételezve, hogy $\tau_{B}$ és $\tau_{C}$ jelenti B és C csődidôpontjait. Jelölje $N_{t}^{i}=1_{\left(\tau_{i} \leq t\right)}, i=\{B, C\}$ a csődindikátor folyamatot, ahol

$$
1_{(a \in \mathcal{A})}= \begin{cases}1, & a \in \mathcal{A} \\ 0, & a \notin \mathcal{A},\end{cases}
$$

továbbá $\mathcal{H}_{t}^{i}=\sigma\left(N_{s}^{i}, 0 \leq s \leq t\right)$ és $\mathcal{H}_{t}=\cup \mathcal{H}_{t}^{i}$ jelenti a csődesemények által generált filtrációt. Végül legyen $R E C_{i}, i \in\{B, C\}$ a csődeseménykori megtérülési ráta.

Fedezet nélkül a partnerkockázattal kiigazított ár az alábbi alakban számítható:

$$
\begin{aligned}
\overline{\Pi(t, T)} & =\Pi(t, T) 1_{(\tau>T)} \\
& +1_{\left(\tau=\tau_{B} \leq T\right)}\left[\Pi\left(t, \tau_{B}\right)+D\left(t, \tau_{B}\right)\left(R E C_{B}\left(V_{\tau_{B}}\right)^{+}-\left(-V_{\tau_{B}}\right)^{+}\right)\right] \\
& +1_{\left(\tau=\tau_{C} \leq T\right)}\left[\Pi\left(t, \tau_{C}\right)+D\left(t, \tau_{C}\right)\left(\left(V_{\tau_{C}}\right)^{+}-R E C_{C}\left(-V_{\tau_{C}}\right)^{+}\right)\right],
\end{aligned}
$$

ahol $\tau=\min \left(\tau_{B}, \tau_{C}\right)$ és $D(t, T)$ a $t$ és $T$ közötti diszkontfaktor.

Brigo et al. (2013) a változó letét figyelembevételével egészítették ki a fenti pénzáramokat. Az általános pénzáram formula felírásához használhatjuk az egyes eseteket részletezô fa ábrát:

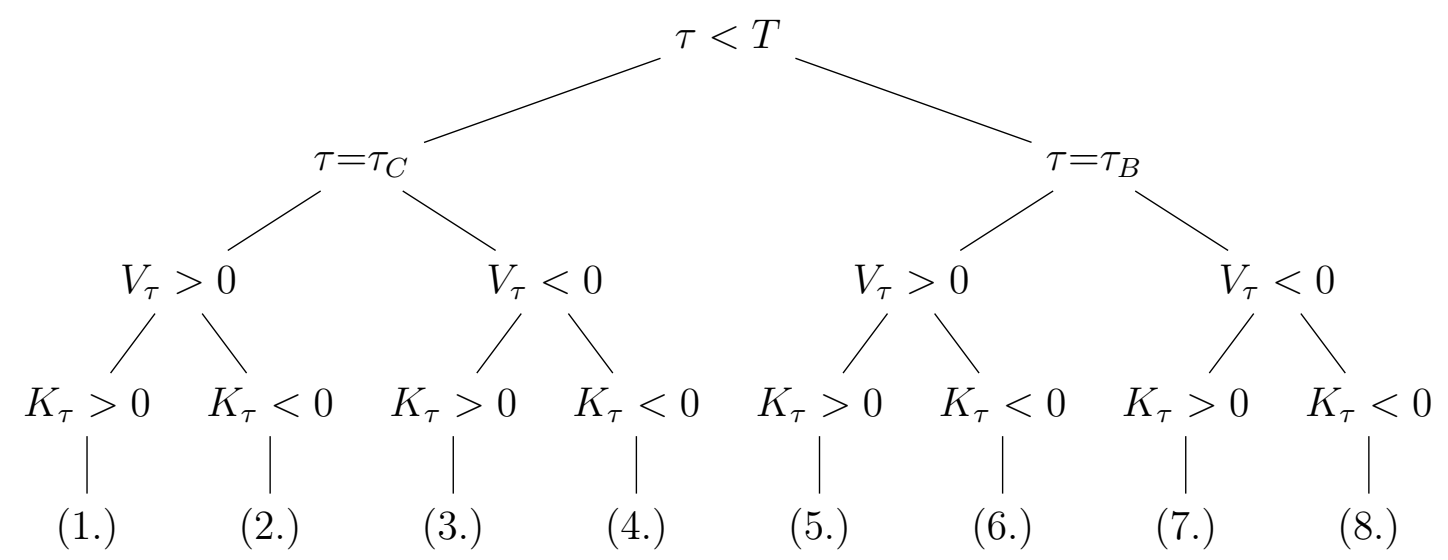

3.1. ábra. A változó letéttel kiegészített CVA számítása - Az összes lehetséges eset

Jelölje $K_{t}$ a fedezeti számla egyenlegét a $t$ idôpontban B szemszögéből. Általánosan megengedhetjük a fedezeti számlán fellépô veszteséget, amelyból származó 
megtérülést a $R E C_{i}^{\prime}, i \in\{B, C\}$ megtérülési számmal írunk le. Ebben az esetben a pénzáramok az alábbi alakot öltik:

$$
\begin{aligned}
& \overline{\Pi(t, T)}=\Pi(t, T) 1_{(\tau>T)}+1_{(\tau<T)}\left(\Pi(t, \tau)+D(t, \tau) K_{\tau}\right) \\
& +1_{\left(\tau_{C}=\tau \leq T\right)} 1_{\left(V_{\tau}>0\right)} 1_{\left(K_{\tau}>0\right)} D(t, \tau)\left(R E C_{C}\left(V_{\tau}-K_{\tau}\right)^{+}+\left(V_{\tau}-K_{\tau}\right)^{-}\right) \\
& +1_{\left(\tau_{C}=\tau \leq T\right)} 1_{\left(V_{\tau}>0\right)} 1_{\left(K_{\tau}<0\right)} D(t, \tau)\left(R E C_{C} V_{\tau}-R E C_{C}^{\prime} K_{\tau}\right) \\
& +1_{\left(\tau_{C}=\tau \leq T\right)} 1_{\left(V_{\tau}<0\right)} 1_{\left(K_{\tau}>0\right)} D(t, \tau)\left(V_{\tau}-K_{\tau}\right) \\
& +1_{\left(\tau_{C}=\tau \leq T\right)} 1_{\left(V_{\tau}<0\right)} 1_{\left(K_{\tau}<0\right)} D(t, \tau)\left(R E C_{C}^{\prime}\left(V_{\tau}-K_{\tau}\right)^{+}+\left(V_{\tau}-K_{\tau}\right)^{-}\right) \\
& +1_{\left(\tau_{B}=\tau \leq T\right)} 1_{\left(V_{\tau}>0\right)} 1_{\left(K_{\tau}>0\right)} D(t, \tau)\left(\left(V_{\tau}-K_{\tau}\right)^{+}+R E C_{B}^{\prime}\left(V_{\tau}-K_{\tau}\right)^{-}\right) \\
& +1_{\left(\tau_{B}=\tau \leq T\right)} 1_{\left(V_{\tau}>0\right)} 1_{\left(K_{\tau}<0\right)} D(t, \tau)\left(V_{\tau}-K_{\tau}\right) \\
& +1_{\left(\tau_{B}=\tau \leq T\right)} 1_{\left(V_{\tau}<0\right)} 1_{\left(K_{\tau}>0\right)} D(t, \tau)\left(R E C_{B} V_{\tau}-R E C_{B}^{\prime} K_{\tau}\right) \\
& +1_{\left(\tau_{B}=\tau \leq T\right)} 1_{\left(V_{\tau}<0\right)} 1_{\left(K_{\tau}<0\right)} D(t, \tau)\left(\left(V_{\tau}-K_{\tau}\right)^{+}+R E C_{B}\left(V_{\tau}-K_{\tau}\right)^{-}\right) .
\end{aligned}
$$

Így például a fa ábrán szerepeltetett 1. esetben, amikor a $\mathrm{C}$ csődjekor B pozitív kitettséggel rendelkezik $\left(V_{\tau}>0\right)$ és valamennyi letét elérhetô számára $\left(K_{\tau}>\right.$ $>0$ ), akkor elsőként csökkenti a kitettség értékét az elérhető fedezet összegével. Amennyiben továbbra is marad valamennyi kitettsége C felé, akkor csakis a megtérülési ráta által meghatározott összeget fogja megkapni, míg ellenkezô esetben a letét fennmaradó értékét visszaadja a partnerének. A fenti egyenletben szereplő tagok a fenti ábra és a példa felhasználásával levezethetőek.

A 3.4. egyenlet egyszerúsítésével felírhatjuk a letéti megállapodás melletti kockázattal kiigazított árat:

$$
\begin{aligned}
\mathbb{E}_{t}[\overline{\Pi(t, T)}]=\mathbb{E}_{t}[\Pi(t, T)] \\
-\mathbb{E}_{t}\left[1_{\left(\tau=\tau_{C}<T\right)} D(t, \tau)\left[\left(1-R E C_{C}\right)\left(V_{\tau}^{+}-K_{\tau}^{+}\right)^{+}-\left(1-R E C_{C}^{\prime}\right)\left(V_{\tau}^{-}-K_{\tau}^{-}\right)^{+}\right]\right] \\
-\mathbb{E}_{t}\left[1_{\left(\tau=\tau_{B}<T\right)} D(t, \tau)\left[\left(1-R E C_{B}\right)\left(V_{\tau}^{-}-K_{\tau}^{-}\right)^{-}-\left(1-R E C_{B}^{\prime}\right)\left(V_{\tau}^{+}-K_{\tau}^{+}\right)^{-}\right]\right],
\end{aligned}
$$

A kétoldalú CVA a partnerkockázat ára, tehát a kockázatmentes és a kockázattal kiigazított ár különbsége. Amennyiben feltételezzük, hogy B kockázatmentes, akkor az egyoldalú CVA definícióját kapjuk. Ahogy az előző fejezetekben már bemutattam és a fenti formulákból is kiolvasható, a hitelértékelési kiigazításnak két fố komponense van: a kitettség profil és a csődvalószínúségek. A következő részben a csődesemények modellezésére összpontosítok és levezetek egy általános keretrendszert a hitelbesorolások megváltozása által okozott fertôzô hatások számszerúsítésére. 


\subsection{A modell}

A következőkben tételezzünk fel $N$ számú vállalatot és $K$ számú különböző hitelminôsítési kategóriát. A kezdeti hitelminôsítéseket az $S_{0}=\left[\eta_{1}^{0}, \eta_{2}^{0}, \ldots, \eta_{N}^{0}\right]$ vektor tartalmazza, ahol $\eta_{i}^{0} \in\{1,2, \ldots, K\}$ tetszóleges $i=1, \ldots, N$ esetén. Így az $i$. vállalat kezdeti hitelbesorolására, mint az $S_{0}$ vektor elemére hivatkozhatunk, azaz $S_{0}[i]=\eta_{i}^{0}$ ahol $i=1, \ldots, N$.

A hitelminősítési kategóriák közötti átmeneteket Lando (1998) egy vállalatra vonatkozó modelljének az általánosításaként fogom modellezni. Az általános eset megértése elôtt érdemes egy leegyszerúsített kerettel kezdeni, ahol egyetlen átmenet létezik, ami nem más, mint a csődesemény. Lando (1998) a csődidőpontot úgy definiálta, mint az első időpont, amikor egy kumulált intenzitás folyamat először lép át egy kívülról adott szintet. Azaz ha $\tau$ jelöli a csődidốpontot, akkor

$$
\tau=\inf \left\{t: \int_{0}^{t} \lambda(s) d s \geq \mathcal{E}\right\}
$$

ahol $\mathcal{E}$ egy exponenciális valószínúségi változó egységnyi várható értékkel, és $\lambda($.) a csốdintenzitás folyamat. A csődintenzitás folyamat lehet konstans, determinisztikus vagy sztochasztikus folyamat. Ebben a modellben a vállalat azonnali csődvalószínüsége megadható $\lambda \Delta t$ formában, amennyiben $\Delta t$ kicsi. A kumulált intenzitásfolyamatot a $\int_{0}^{t} \lambda(s) d s$ formában adhatjuk meg. A fentiekból már következik, hogy determinisztikus intenzitás folyamat esetében:

$$
\mathbb{Q}[\tau>T]=e^{-\int_{0}^{T} \lambda(s) d s} .
$$

A redukált formájú csődmodellek részletesebb leírását az 1.2.2, fejezetben találhatja az érdeklődő Olvasó. Egy több vállalatot lefedő esetben a 3.6. egyenlettel adott definíció általánosítható, ha feltételezzük, hogy minden vállalathoz hozzárendelhetünk egy intenzitás folyamatot és egy exponenciális valószínúségi változót. A sztochasztikus intenzitásfolyamatok korrelációjával és/vagy az exponenciális valószínûségi változók egy kopulával történô összekapcsolásával csődesemények közötti függőség is bevezethetô a modellbe.2 $2^{2}$

Lando (1998) a fenti modellt általánosította annak érdekében, hogy a hitelminôsítési besorolások változását számszerúsítse. Az általános keretben a hitelminôsítési átmenet idôpontját az alábbiak szerint definiálta:

$$
\tau^{1}=\inf \left\{t: \int_{0}^{t} \lambda_{\eta_{0} j}(s) d s \geq \mathcal{E}_{1 j}\right\}, j=1, \ldots, K ; j \neq \eta_{0},
$$

ahol $\left\{\mathcal{E}_{11}, \mathcal{E}_{12}, \ldots, \mathcal{E}_{1 K}\right\}$ független, egységnyi exponenciális valószínúségi változók sorozata és $\eta_{0}$ a vállalat kezdeti hitelbesorolása. Ebben a keretben a $\lambda_{\eta_{0} j}($.$) a$

${ }^{2}$ Ezek részleteiért az alábbi munkákat javaslom: Brigo et al. (2013) vagy Zheng $(2013)$. 
hitelminősítési kategóriák közötti átmenetet leíró intenzitás mátrix $\eta_{0}$. sorának és $j$. oszlopának eleme. Az elsố hitelminôsítési átmenet tehát előáll, mint az elsô idôpont, amikor az egyes kategóriákhoz rendelt kumulált átmenetintenzitás folyamatok közül az egyik átlép egy, a kategóriához rendelt véletlen mennyiséget. A $\tau^{1}$ időpontot követő hitelátmenetet az alábbi formában definiálhatjuk:

$$
\tau^{2}=\inf \left\{t: \int_{\tau_{1}}^{t} \lambda_{\eta_{1} j}(s) d s \geq \mathcal{E}_{2 j}\right\}, j=1, \ldots, K ; j \neq \eta_{1},
$$

ahol $\left\{\mathcal{E}_{21}, \mathcal{E}_{22}, \ldots, \mathcal{E}_{2 K}\right\}$ független, egységnyi exponenciális valószínúségi változók egy új sorozata. Ez alapján már tetszőleges hitelátmenetet definiálhatunk egészen a vállalat csődeseményéig. A csődeseményt a legrosszabb besorolásba történô átmenetként adhatjuk meg, amely egy „elnyelő” kategória, azaz az intenzitás mátrix utolsó sora csupa nullát tartalmaz. Így tehát az $n$. átmenet előáll az alábbiak szerint:

$$
\tau^{n}=\inf \left\{t: \int_{\tau_{n-1}}^{t} \lambda_{\eta_{n-1} j}(s) d s \geq \mathcal{E}_{(n-1) j}\right\}, j=1, \ldots, K ; j \neq \eta_{n-1},
$$

és amennyiben $\tau^{n}$ idôpontban a $j=K$ átmenetbe történik az átmenet, akkor $\tau^{n}$ a vállalat csődidőpontja.

Lando (1998) munkája alapján, a következôkben egy általános modellkeretet adok meg, amely a hitelminôsítési kategóriák közötti átmenetek mellett azok fertôzô hatásait is figyelembe veszi. Modellemben bevezetem a feltételes intenzitás folyamatot, amit a feltétel nélküli folyamat átskálázásával kapok. A skálázó faktor figyelembe veszi az összes hitelminôsítés változást és annak megfelelôen változtatja az intenzitás folyamatot. Például egy vállalat leminôsítésekor növeli az adott vállalat intenzitás folyamatát, ugyanakkor csökkenti a társakét.

Jelölje $\lambda_{j}^{i}(t)$ az $i$. vállalat $j$. hitelminősítésbe való átmenetéhez rendelt, a korábbi hitelminôsítés változásokra vett feltételes intenzitás folyamatát a $t$. idôpontban:

$$
\lambda_{j}^{i}(t)=\lambda_{j}^{i}\left(t \mid T_{n}, S_{n}, G_{n}^{i}, R_{n}^{i}\right),
$$

ahol $T_{n}=\left\{t_{1}, t_{2}, t_{3}, \ldots, t_{n}\right\}$ jelöli az összes korábbi hitelminősítés változás időpontjainak halamazát, így $t_{n}<t$. Az $\mathcal{S}_{n}=\left\{S_{0}, S_{1}, \ldots, S_{n}\right\}$ az egyes vállalatok hitelminősítési múltjainak a halmaza, ahol is $S_{k}=\left[\eta_{1}^{k}, \eta_{2}^{k}, \ldots, \eta_{N}^{k}\right]$ a $k$. átmenet után megfigyelt hitelminősítések. Végül $G_{n}^{i}=\left\{g_{1}^{i}, g_{2}^{i}, \ldots, g_{\hat{n}}^{i}\right\} \subseteq T_{n}$ tartalmazza az összes időpontot, amikor $i$ hitelbesorolása változott és $r_{u}^{i} \in\left[r_{1}^{i}, r_{2}^{i}, \ldots, r_{\hat{n}}^{i}\right]=R_{n}^{i}$ jelenti az új hitelminôsítési kategóriát, ahová $i$ került a $g_{u}^{i}$ idôpontban.

A bevezetésre kerülő modellben a $\lambda_{j}^{i}\left(t \mid T_{n}, S_{n}, G_{n}^{i}, R_{n}^{i}\right)$ feltételes intenzitás fo- 
lyamatot az alábbi formában specifikálom:

$$
\begin{aligned}
& \lambda_{j}^{i}\left(t \mid T_{n}, \mathcal{S}_{n}, G_{n}^{i}, R_{n}^{i}\right)= \\
& a_{j}^{i}(t)\left(1+\sum_{h=1}^{n}\left(d_{1}^{\mathrm{le}}\left(1_{\left(S_{h}>S_{h-1}\right)} \mathbf{1}\right)+d_{1}^{\mathrm{fel}}\left(1_{\left(S_{h}<S_{h-1}\right)} \mathbf{1}\right)\right.\right. \\
& \quad+d_{2}^{\mathrm{le}}\left(1_{\left(S_{h}>S_{h-1}\right)}[i]\right)+d_{2}^{\mathrm{fel}}\left(1_{\left(S_{h}<S_{h-1}\right)}[i]\right) \\
&\left.\left.\quad+d_{3} \sum_{v=1}^{N} 1_{\left(\left(S_{h}[v]=K\right) \cap\left(S_{h-1}[v] \neq K\right)\right)}\right) e^{-p\left(t-t_{h}\right)}\right),
\end{aligned}
$$

ahol $a_{j}^{i}(t)$ a feltétel nélküli intenzitás folyamat, $\mathbf{1}=[1,1, \ldots, 1] \in \mathbb{R}^{N \times 1}$ az összegzô vektor, és ahogy korábban, $1_{(.)}$jelöli az indikátor függvényt, amit vektorok esetében annak elemein értelmezek, azaz annak értéke is vektor. Az $\left(S_{h}>S_{h-1}\right)$ és az $\left(S_{h}<S_{h-1}\right)$ összehasonlításokat így a vektorok elemein végzem el I $^{3}$ A hitelminősítések közötti átmeneteket megbontva, le- $\left(1_{\left(S_{h}>S_{h-1}\right)}\right)$ és felminősítések $\left(1_{\left(S_{h}<S_{h-1}\right)}\right)$ formájában kerülnek felhasználásra. Az 1 vektort használom, hogy összegezzem ezeket a vektorokat az összes vállalatra, vagy éppen a korábban bevezetett $[i]$ jelöléssel hivatkozok a vektor $i$. elemére.

Így már láthatjuk, hogy a feltételes intenzitás folyamat minden idôpontban a feltétel nélküli intenzitás folyamat és egy speciális tényezô szorzataként áll elő. A tényező függ a múltbeli hitelminôsítés változásoktól és a modell paramétereitôl, amelyeket a $\left\{d_{1}^{\text {le }}, d_{1}^{\text {fel }}, d_{2}^{\text {le }}, d_{2}^{\text {fel }}, d_{3}, p\right\}$ halmazzal adhatjuk meg. Értelemszerúen $d_{1}^{\text {le }}$ és $d_{1}^{\text {fel }}$ tetszóleges vállalat hitelbesorolásának változására vonatkozó érzékenysé-

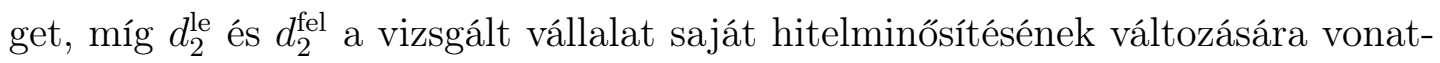
kozó érzékenységet mutatják. Hasonló szerepet kap $d_{3}$, azonban ez kifejezetten a csốdesemények hatását számszerúsíti. Végül $p$ a hatások lecsengését szabályozó érték.

Ez a modellkeret lehetôvé teszi, hogy Micu et al. (2006), Finnerty et al. (2013), Wengner et al. (2015) és Jorion és Zhang (2009) empirikus megfigyeléseit beillesszük a modellbe. Megfelelő paraméter beállításokkal a 3.12 . egyenletben szereplố kiigazító tényezô csökkenti az intenzitás folyamatát az $i^{\prime} \neq i$ vállalatoknak $i$ leminősítése után, míg növeli azt az $i$. esetében. Egy csődesemény minden vállalat intenzitás folyamatát növeli. Hogy az újabb események nagyobb súlyt kapjanak a korábbiakkal szemben, az intenzitás folyamatban bekövetkező változások hatása exponenciális ütemben csökken az idô múlásával.

Végül specifikálni kell a 3.12 , egyenletben szereplő $j$ index értékkészletét. Erre a kérdésre két alternatív kalibrációs opciót javaslok. Az elsố esetben csakis a legrosszabb hitelminősítés intenzitás folyamatát sokkoljuk, azaz $j=K$. Alternatív megoldásként alkalmazhatjuk a sokkot csupán az aktuális hitelminőségnél

${ }^{3}$ Ez nem okoz problémát, hiszen a hitelkategóriákat numerikus skálán definiáltam a fejezet elején: $\eta_{i}^{0} \in\{1,2, \ldots, K\}$ tetszóleges $i=1, \ldots, N$. 
rosszabb hitelbesorolásokra. Ebben az esetben a fertôzés ténylegesen befolyásolja a jövôbeli hitelminôsítéseket és nem csak a csődeseményt. A bemutatott számpéldában is ezt a megoldást preferálom. Arra azonban már most felhívom a figyelmet, hogy a modell paramétereket a választott opció függvényében újra kell kalibrálni.

Az intenzitás folyamatok a megfigyelt hitelminôsítés változásokon alapuló átskálázása örököli a körkörös csôdesemények problémáját. Az itteni probléma abból ered, hogy egy vállalat hitelbesorolását meghatározó intenzitás folyamatok szimulálásához figyelembe kell venni az összes hitelbesorolás változást. Ezeket azonban az egyes vállalatok intenzitás folyamatai határozzák meg, amik függenek az elsô vállalat hitelbesorolás változásától. A fentebb megadott általános modellkeretben nem adható analitikus megoldás a csődidőpontokra, ezért egy alternatív módszert kell keresni annak érdekében, hogy a modell a partnerkockázat árazására használható legyen.

A Yu (2007) által fejlesztett algoritmus közvetlenül nem alkalmazható a fertôző hitelbesorolás változások modelljére, hiszen $\mathrm{Yu}(2007)$ nem foglalkozott hitelminősítési átmenetekkel. Az általa adott eljárásban a vállalatok két állapotot vehetnek fel: fizetóképes vagy már nem tud teljesíteni. Jelen probléma azonban a hitelminôsítési kategóriák miatt sokkal granulárisabb. A hitelbesorolások önmagukban is hatással vannak az intenzitás folyamatra, így egy azokat figyelembe vevô eljárásra van szükség, amihez Yu (2007) módszerének általánosításával juthatunk el. A teljes hazard eljáráshoz elsóként szükség van a kumulált hazard függvényre, amit az alábbiak szerint definiálok:

$$
\Lambda_{j}^{i}\left(s \mid T_{m}, \mathcal{S}_{m}, G_{m}^{i}, R_{m}^{i}\right)=\int_{t_{m}}^{t_{m}+s} \lambda_{j}^{i}\left(u \mid T_{m}, \mathcal{S}_{m}, G_{m}^{i}, R_{m}^{i}\right) d u .
$$

A kumulált hazard függvény a feltételes intenzitás folyamat integrálja, feltéve, hogy a hitelminősítési információt az integrálási időintervallum kezdeténél rögzítjük.

A kumulált hazard függvény alapján definiálható a teljes hazard függvény:

$$
\begin{aligned}
& \Psi_{j}^{i}\left(t \mid T_{n}, \mathcal{S}_{n}, G_{n}^{i}, R_{n}^{i}\right)= \\
& \sum_{f=1}^{n} \sum_{m=1}^{n} \Lambda_{r_{f}^{i}}^{i}\left(t_{m}-t_{m-1} \mid T_{m-1}, \mathcal{S}_{m-1}, G_{m-1}^{i}, R_{m-1}^{i}\right) \mathbf{1}_{\left(t_{m} \in\left(g_{f-1}^{i}, g_{f}^{i}\right]\right)}+ \\
& \sum_{m=1}^{n} \Lambda_{j}^{i}\left(t_{m}-t_{m-1} \mid T_{m-1}, \mathcal{S}_{m-1}, G_{m-1}^{i}, R_{m-1}^{i}\right) \mathbf{1}_{\left(t_{m}>g_{\hat{n}}^{i}\right)}+\Lambda_{j}^{i}\left(t-t_{n} \mid T_{n}, \mathcal{S}_{n}, G_{n}^{i}, R_{n}^{i}\right) .
\end{aligned}
$$

A 3.14. egyenlet három részre osztható. Az elsô rész az $i$. vállalat intenzitás folyamatát aggregálja az összes hitelbesorolás változás idôponton keresztül egészen addig, amíg az $i$. vállalat utoljára váltott hitelbesorolást. A második tag számszerúsíti az összes lehetséges intenzitás folyamat utat az $i$. vállalat legutolsó átminôsítésétől egészen az utolsó hitelminôsítői bejelentésig. Az utolsó tag mutatja a 
kumulált intenzitás folyamatot a piacot érintő legutolsó hitelminősítés változástól, hiszen definíció szerint a $\left(t_{n}, t\right)$ intervallumon egyetlen vállalat sem váltott hitelbesorolást. Vegyük észre, hogy a három tag ugyanazzal a felosztási részletességgel van megadva, de az utolsó két tag függ a lehetséges következő hitelbesorolástól (j), míg az elsố nem. Erre a szétválasztásra azért van szükség, mert a kumulált intenzitás folyamat változhat, ha bármelyik vállalat hitelminősítői kategóriát vált. Amikor egy vállalat hitelbesorolása változik, akkor az exponenciális változótól való távolsága nullára csökken. Miközben, ha egy másik vállalat vált hitelbesorolást, akkor az elóbbi távolság pozitív marad, de a közeledés tempója változik. Tehát, hogy meghatározzuk az exponenciális változó eléréséhez szükséges tényleges időt, minden egyes sebesség változtató hatást figyelembe kell vennünk.

Végül Yu (2007) tanulmányához hasonlóan definiálom a kumulált intenzitás folyamat általánosított inverzét az alábbiak szerint:

$$
\Lambda_{j}^{i}\left(x \mid T_{n}, \mathcal{S}_{n}, G_{n}^{i}, R_{n}^{i}\right)^{-1}=\inf \left\{s: \Lambda_{j}^{i}\left(s \mid T_{n}, \mathcal{S}_{n}, G_{n}^{i}, R_{n}^{i}\right) \geq x\right\} .
$$

Most, hogy az algoritmus összes építő elemét definiáltam, lépésrôl lépésre leírva megadhatom azt:

\section{A kiterjesztett teljes hazard eljárás:}

1. Generáljunk véletlenszámokat exponenciális eloszlásból. Jelöljön $\mathcal{E}$ egy $N \times$ $\times K$ méretú mátrixot, amire $\mathcal{E}_{i j} \sim \operatorname{Exp}(1)$ minden $i=1,2, \ldots, N$ és $j=$ $=1,2, \ldots, K$.

2. Adjuk meg az index halmazok kezdeti értékeit az alábbi formában: $T_{0}=0$, $S_{0}=\left[\eta_{1}^{0}, \eta_{2}^{0}, \ldots, \eta_{N}^{0}\right], G_{0}^{i}=0$ és $R_{0}^{i}=\eta_{i}^{0}$. Ezután találjuk meg az alábbi feladat megoldását:

$$
\left(k_{1}, r_{1}\right)=\underset{\{1 \leq i \leq N, 1 \leq j \leq K\}}{\arg \min } \Lambda_{j}^{i}\left(\mathcal{E}_{i j} \mid T_{0}, \mathcal{S}_{0}, G_{0}^{i}, R_{0}^{i}\right)^{-1},
$$

ahol $r_{1}$ jelöli a hitelbesorolást, ahová a $k_{1}$ vállalat mozdul és

$$
t_{1}=\Lambda_{r_{1}}^{k_{1}}\left(\mathcal{E}_{k_{1} r_{1}} \mid T_{0}, \mathcal{S}_{0}, G_{0}^{k_{1}}, R_{0}^{k_{1}}\right)^{-1}
$$

az első átmenet ideje.

3. Frissítsük az index halmazokat: $T_{1}=T_{0} \cup t_{1}, G_{1}^{k_{1}}=G_{0}^{k_{1}} \cup t_{1}, R_{1}^{k_{1}}=R_{0}^{k_{1}} \cup r_{1}$ és

$$
S_{1}[i]= \begin{cases}S_{0}[i] & i \neq k_{1} \\ r_{1} & i=k_{1} .\end{cases}
$$

4. Generáljunk egységnyi exponenciális valószínúség eloszlásból $K$ elemú független mintát és adjuk az $\mathcal{E}_{k_{1} r_{1}}$ mennyiséget mindegyikhez. Végül cseréljük le az $\mathcal{E}$ mátrix $k_{1}$. sorát ezekkel az új értékekkel. 
5. Az $m$. hitelminôsítési változás meghatározásához oldjuk meg az az alábbiakat:

$$
\begin{aligned}
& \left(k_{m}, r_{m}\right)= \\
& \underset{\{1 \leq i \leq N, 1 \leq j \leq K\}}{\arg \min }\left(\Lambda_{j}^{i}\left(\mathcal{E}_{i j}-\Psi_{j}^{i}\left(t_{m-1} \mid T_{m-1}, \mathcal{S}_{m-1}, G_{m-1}^{i}, R_{m-1}^{i}\right) \mid T_{m-1}, \mathcal{S}_{m-1}, G_{m-1}^{i}, R_{m-1}^{i}\right)^{-1}\right)
\end{aligned}
$$

és

$$
\begin{aligned}
t_{m}= & t_{m-1}+ \\
& \Lambda_{r_{m}}^{k_{m}}\left(\varepsilon_{k_{m} r_{m}}-\Psi_{r_{m}}^{k_{m}}\left(t_{m-1} \mid T_{m-1}, \mathcal{S}_{m-1}, G_{m-1}^{k_{m}}, R_{m-1}^{k_{m}}\right) \mid T_{m-1}, \mathcal{S}_{m-1}, G_{m-1}^{k_{m}}, R_{m-1}^{k_{m}}\right)^{-1}
\end{aligned}
$$

6. Frissítsük az index halmazokat: $T_{m}=T_{m-1} \cup t_{m}, G_{m}^{k_{m}}=G_{m-1}^{k_{m}} \cup t_{m}, R_{m}^{k_{m}}=$ $=R_{m-1}^{k_{m}} \cup r_{m}$ és

$$
S_{m}[i]= \begin{cases}S_{m-1}[i] & i \neq k_{m} \\ r_{m} & i=k_{m} .\end{cases}
$$

7. Generáljunk egységnyi exponenciális valószínúség eloszlásból $K$ elemú független mintát és adjuk az $\mathcal{E}_{k_{m} r_{m}}$ mennyiséget mindegyikhez. Végül cseréljük le az $\mathcal{E}$ mátrix $k_{m}$. sorát ezekkel az új értékekkel.

8. Ismételjük az algoritmust annak 5. pontjától addig, amíg van legalább egy vállalat, amely nem csődölt, vagy amíg el nem értük a kívánt szimulációs hosszt.

A korábban adott modellkerettel és a most leírt algoritmussal egy eszközt kaptunk ahhoz, hogy megvizsgáljuk a hitelbesorolás változások fertôzố hatásait az egyes vállalatok csődeseményeire. Megadott algoritmus modellspecifikációk széles köre mellett felhasználható. Továbbá speciális esetben, ahol $K=2$ az algoritmus megegyezik az eredeti teljes hazard eljárással. Mint ismert, a hitelértékelési kiigazítás erôsen függ a használt modelltôl, ezért kifejezetten fontos, hogy olyan modelleket használjunk, amelyek figyelembe veszik az empirikus kutatások eredményeit. A következő részben egy numerikus példát használva vizsgálom meg, hogy a hitelbesorolás változások fertôző hatásai, hogyan érintik a hitelminősítési kiigazítás értékét.

\subsection{Numerikus példa}

Az előző részben bevezetett modellkeret és a hozzátartozó megoldó algoritmus intenzitás folyamatok széleskörú családjára alkalmazhatóak. A szimulációs algoritmus elônye sztochasztikus intenzitás folyamatok mellett válik igazán világossá. 
3.1. táblázat. Kiinduló egy éves átmenetmátrix

\begin{tabular}{lccccccccc}
\hline & Aaa & Aa & A & Baa & Ba & B & Caa & Ca\&C & D \\
Aaa & $90,4 \%$ & $8,9 \%$ & $0,6 \%$ & $0,0 \%$ & $0,0 \%$ & $0,0 \%$ & $0,0 \%$ & $0,0 \%$ & $0,0 \%$ \\
Aa & $1,0 \%$ & $90,1 \%$ & $8,4 \%$ & $0,4 \%$ & $0,0 \%$ & $0,0 \%$ & $0,0 \%$ & $0,0 \%$ & $0,0 \%$ \\
A & $0,1 \%$ & $2,8 \%$ & $90,9 \%$ & $5,5 \%$ & $0,5 \%$ & $0,1 \%$ & $0,0 \%$ & $0,0 \%$ & $0,1 \%$ \\
Baa & $0,0 \%$ & $0,2 \%$ & $4,8 \%$ & $89,4 \%$ & $4,4 \%$ & $0,8 \%$ & $0,2 \%$ & $0,0 \%$ & $0,2 \%$ \\
Ba & $0,0 \%$ & $0,1 \%$ & $0,4 \%$ & $6,2 \%$ & $83,4 \%$ & $8,0 \%$ & $0,6 \%$ & $0,1 \%$ & $1,2 \%$ \\
B & $0,0 \%$ & $0,0 \%$ & $0,1 \%$ & $0,4 \%$ & $5,3 \%$ & $82,2 \%$ & $6,4 \%$ & $0,7 \%$ & $4,7 \%$ \\
Caa & $0,0 \%$ & $0,0 \%$ & $0,0 \%$ & $0,2 \%$ & $0,5 \%$ & $9,4 \%$ & $68,4 \%$ & $4,7 \%$ & $16,8 \%$ \\
Ca\&C & $0,0 \%$ & $0,0 \%$ & $0,0 \%$ & $0,0 \%$ & $0,4 \%$ & $2,8 \%$ & $10,7 \%$ & $43,5 \%$ & $42,6 \%$ \\
D & $0,0 \%$ & $0,0 \%$ & $0,0 \%$ & $0,0 \%$ & $0,0 \%$ & $0,0 \%$ & $0,0 \%$ & $0,0 \%$ & $100,0 \%$ \\
\hline
\end{tabular}

Az ilyen, úgynevezett Cox folyamatok esetében minden egyes vállalat minden hitelbesorolásához tartozik egy sztochasztikus intenzitás folyamat. Ez azonban jelentôs paraméterezési kérdéseket vet fel. Ugyan egy vállalatra ilyen típusú elméleti modellt vezetett be Lando (1998), de ô sem tért ki a kalibrálás részleteire. Cox-Ingersoll-Ross folyamat alapú sztochasztikus intenzitást használnak Brigo és Alfonsi (2005), akik viszont hitelminôsítések nélkül csak egy intenzitás folyamatot, a csődintenzitást definiálják. Erre az ad lehetôséget, hogy a hitelmulasztási ügyletek segítségével megbecsülhetjük a piacon megfigyelt kockázatsemleges csődvalószínúségeket. Hogy elkerüljem a kalibrációs nehézségeket, valamint hogy ne bonyolítsam túl a magyarázatként funkcionáló jelen fejezetet, egy egyszerúbb példát fogok felhasználni. Ennek megfelelôen konstans intenzitás folyamatokkal fogok dolgozni. Ezek lehetôségeket teremtenek arra, hogy kitérjek a modell kalibrációjára, miközben valós adatokon tesztelem a hitelbesorolás változások fertőző hatásait.

Számpéldámban $N=5$ vállalatot és $K=9$ hitelminősítési kategóriát vizsgáltam. Kiindulásként a Moody's által publikált átmenetmátrixot használtam fel, amelyet 3.1. táblázatban közlök. . $^{4}$

A mátrix az egyes hitelminősítési kategóriák közötti egy éves periódusra vonatkozó átmenetvalószínúségeket adja meg. Így például egy A minôsítésú vállalat $5.5 \%$ valószínúséggel fog egy év után a Baa hitelminősítési kategóriába tartozni. A fenti átmenetmátrix azonban valós megfigyeléseken alapul, amelyek közvetve nem használhatóak fel. Az árazási probléma miatt szükség van a kockázatsemleges mérték alatt számolt átmenetvalószínúségi mátrixra. Számos eljárás létezik a

${ }^{4} \mathrm{Az}$ átmenetmátrix elérhető a Moody’s által kiadott „Corporate Default and Recovery Rates 1920-2010” dokumentumban. Az eredeti átmenetvalószínúségek között szerepel egy „WR” oszlop, amely a sor szerinti hitelbesorolás visszavonásának a valószínúségét mutatja. Ezt az oszlopot az elemzés során figyelmen kívül hagytam. Így elôször töröltem azt a mátrixból, majd az összes megmaradó átmenetvalószínûséget átskáláztam, hogy a sorok összege egységnyi legyen. 
valós átmenetvalószínûségek kockázatmentes világba történő áttranszformálására. A módszerek egy családja csak a valós átmenetmátrixot és a kockázatsemleges mérték alatt számolt csôdvalószínúségeket használja. Ezen eljárások célja, hogy a valós mátrix utolsó oszlopát, a csôdvalószínúségeket a piacon megfigyelt kockázatmentes csốdvalószínúségekhez kalibrálja, megốrizve az átmenetmátrix jelleget. Természetesen ennek a feladatnak több megoldása is létezik. Trueck és Rachev (2009) alapján a valós és a kockázatsemleges csődvalószínúségek közötti jelentôs különbség esetén érdemes az intenzitás mátrix teljes sorát skálázni, amelyet eredetileg Lando (2000) javasolt. Mivel a jelen esetben is jelentôs különbségek állnak fenn, ezért ezt a módszert használtam, amit az alábbiakban be is mutatok ${ }^{5}$

Jelölje $\Lambda_{M}$ az intenzitás mátrixot, azaz:

$$
\Lambda_{M}=\left[\begin{array}{cccc}
\lambda_{11} & \lambda_{12} & \cdots & \lambda_{1 K} \\
\lambda_{21} & \lambda_{22} & \cdots & \lambda_{2 K} \\
\vdots & & \ddots & \\
\lambda_{K 1} & \lambda_{K 2} & \cdots & \lambda_{K K}
\end{array}\right]
$$

és

$$
\mathcal{Q}=\exp \left(\Lambda_{M}\right)
$$

ahol $\mathcal{Q}$ az átmenet valószínûség mátrix. Lando (2000) eljárását követve az intenzitás mátrix egyes sorait úgy kell átskálázni, hogy az azokból újraszámolt átmenet valószínúség mátrix utolsó sora a megfigyelt kockázatsemleges csődvalószínüségekkel egyezzen meg. Ennek megfelelően meghatározhatunk egy olyan $\left\{\pi_{1}, \pi_{2}, \cdots, \pi_{K}\right\}$ sorozatot, amelyekre teljesül, hogy

$$
\mathcal{Q}^{\prime}=\exp \left(\Lambda_{M}^{\prime}\right)
$$

utolsó oszlopa megegyezik az egyes hitelminősítési kategóriákhoz megfigyelt kockázatsemleges csôdvalószínúségekkel, ahol

$$
\Lambda_{M}^{\prime}=\left[\begin{array}{cccc}
\lambda_{11} \pi_{1} & \lambda_{12} \pi_{1} & \cdots & \lambda_{1 K} \pi_{1} \\
\lambda_{21} \pi_{2} & \lambda_{22} \pi_{2} & \cdots & \lambda_{2 K} \pi_{2} \\
\vdots & & \ddots & \\
\lambda_{K 1} \pi_{K} & \lambda_{K 2} \pi_{K} & \cdots & \lambda_{K K} \pi_{K}
\end{array}\right]
$$

Az így kapott kockázatsemleges átmenetmátrixot a 3.2. táblázatban közlöm. A következő lépésként a modellben szereplő paramétereket kell meghatározni, ami egy, a fentiekhez hasonló eljáráson keresztül tehető meg. Az empirikus tanulmányok alapján ismert, hogy a hitelminősítési intézmények egyes bejelentései milyen

${ }^{5}$ Az általam felhasznált kockázatsemleges csődvalószínúíségek is Moody's-tól származnak. A Moody's rendszeresen közzéteszi az egyes iparágak hitelminôsítés szerint bontott medián hitelfelárát. A pénzügyi szektor 2018 febuár 20-án közétett adatait használtam fel a csôdvalószínúség számítására. Az így kapott értékeket a 3.2 táblázat utolsó sora mutatja. 
3.2. táblázat. Kockázatsemleges egy éves átmenetmátrix

\begin{tabular}{lccccccccc}
\hline & Aaa & Aa & A & Baa & Ba & B & Caa & Ca\&C & D \\
Aaa & $79,6 \%$ & $2,9 \%$ & $11,5 \%$ & $4,2 \%$ & $1,0 \%$ & $0,3 \%$ & $0,1 \%$ & $0,0 \%$ & $0,3 \%$ \\
Aa & $11,1 \%$ & $2,8 \%$ & $41,9 \%$ & $30,6 \%$ & $9,1 \%$ & $2,6 \%$ & $0,7 \%$ & $0,1 \%$ & $1,0 \%$ \\
A & $3,0 \%$ & $2,6 \%$ & $42,8 \%$ & $35,1 \%$ & $11,3 \%$ & $3,3 \%$ & $0,8 \%$ & $0,1 \%$ & $1,0 \%$ \\
Baa & $0,8 \%$ & $1,0 \%$ & $17,6 \%$ & $48,2 \%$ & $22,3 \%$ & $7,0 \%$ & $1,4 \%$ & $0,2 \%$ & $1,5 \%$ \\
Ba & $0,1 \%$ & $0,1 \%$ & $2,4 \%$ & $10,6 \%$ & $62,6 \%$ & $18,8 \%$ & $1,9 \%$ & $0,3 \%$ & $3,1 \%$ \\
B & $0,0 \%$ & $0,0 \%$ & $0,2 \%$ & $0,7 \%$ & $6,0 \%$ & $77,2 \%$ & $8,9 \%$ & $1,1 \%$ & $5,8 \%$ \\
Caa & $0,0 \%$ & $0,0 \%$ & $0,0 \%$ & $0,1 \%$ & $0,4 \%$ & $6,6 \%$ & $77,1 \%$ & $4,3 \%$ & $11,5 \%$ \\
Ca\&C & $0,0 \%$ & $0,0 \%$ & $0,0 \%$ & $0,0 \%$ & $0,2 \%$ & $1,3 \%$ & $5,9 \%$ & $70,9 \%$ & $21,7 \%$ \\
D & $0,0 \%$ & $0,0 \%$ & $0,0 \%$ & $0,0 \%$ & $0,0 \%$ & $0,0 \%$ & $0,0 \%$ & $0,0 \%$ & $100,0 \%$ \\
\hline
\end{tabular}

3.3. táblázat. A modell paramétereinek becsült értékei.

\begin{tabular}{lc}
\hline Paraméter & Becsült együttható: \\
\hline$d_{1}^{\text {le }}$ & -0.0124 \\
$d_{1}^{\text {fel }}$ & 0.0019 \\
$d_{2}^{\text {le }}$ & $0.0076-d_{1}^{\text {le }}$ \\
$d_{2}^{\text {fel }}$ & $-0.0129-d_{1}^{\text {fel }}$ \\
$d_{3}$ & $0.0607-d_{1}^{\text {le }}$ \\
\hline
\end{tabular}

változást okoznak a hitelfelárakban. A kiinduló hitelfelárakra alkalmazva ezeket, minden egyes bejelentés típusra megbecsülhetjük a módosított kockázatsemleges csődvalószínúségeket. Ekkor minden $x \in\left\{d_{1}^{\text {le }}, d_{1}^{\text {fel }}, d_{2}^{\text {le }}, d_{2}^{\text {fel }}, d_{3}\right\}$ paramétert úgy kell meghatározni, hogy az eredeti kockázatsemleges intenzitásra teljesüljön az alábbi:

$$
\Lambda_{M}^{\prime \prime}(x)=\left[\begin{array}{cccc}
\lambda_{11}^{\prime} & \lambda_{12}^{\prime} x & \cdots & \lambda_{1 K}^{\prime} x \\
\lambda_{21}^{\prime} & \lambda_{22}^{\prime} & \cdots & \lambda_{2 K}^{\prime} x \\
\vdots & & \ddots & \\
\lambda_{K 1}^{\prime} & \lambda_{K 2}^{\prime} & \cdots & \lambda_{K K}^{\prime}
\end{array}\right] \Rightarrow Q^{\prime \prime}(x)=\exp \left(\Lambda_{M}^{\prime \prime}(x)\right) \Rightarrow Q^{\prime \prime}(x) 1^{K}=q^{e m p},
$$

ahol $1^{K}$ a $K \times K$ egységmátrix utolsó oszlopa és $q^{e m p}$ az empirikusan megfigyelt csődvalószínúség. Vegyük észre, hogy csak az átlótól jobbra eső intenzitásokat sokkoljuk, ahogy az már korábban kifejtésre került. Az egyes paraméterek kalibrált értékeit a 3.3. táblázatban adtam meg. A modell szerkezete miatt bizonyos esetekben korrigálni kell az együtthatókkal. Így például az $i$. vállalat leminősítésekor annak hatása először a 3.12. egyenletben szereplő multiplikátor első tagjában jelentkezik, majd a harmadik tagban is. Mivel ez az esemény $i$ szemszögéból nem egy társ leminősítésének számít, ezért az első tag hatásának nullával kell megegyeznie, amit a $d_{2}^{\text {le }}$ tag korrigálásával érek el. Ezért adtam meg a paramétereket bizonyos esetekben egymástól függően. A számpéldában $p$ paramétert nem kalibráltam, hanem az arra vonatkozó érzékenységet három értéken $(p \in\{0.4,0.7,1\})$ keresztül szemléltetem.

Mivel érezhetjük, hogy a kiinduló hitelbesorolásoknak jelentôs szerepe lehet, 
3.4. táblázat. A fennmaradó négy vállalat hitelminősítése csoportonként

\begin{tabular}{lc}
\hline & Hitelbesorolás: \\
\hline 1. Csoport & Aa; Aa; A; Baa \\
2. Csoport & Aa; Baa; B; Ca\&C \\
3. Csoport & Ca\&C; Caa; Caa; B \\
\hline
\end{tabular}

ezért három csoportot tételeztem fel, és mindháromban négy alternatív szcenáriót vizsgáltam. A kiemelt szerepet kapó vállalatok Aa, Baa, B, Ca\&C kiinduló hitelminôsítésekkel szerepelnek és a csoportokban szereplő fennmaradó négy vállalat hitelminősítését a 3.4. táblázatban foglaltam össze.

Első lépésként a korábban adott algoritmussal csődeseményeket szimuláltam egy 10 éves időhorizontra, majd ezekból megbecsültem a túlélési valószínûségeket. Az eredményeket a 3.2 ábrán szemléltetem.

A 3.2 ábráról leolvasható, hogy a túlélési valószínúségekben kirajzolódó különbségek jellemzôen néhány év után válnak igazán láthatóvá. Sejtésünknek megfelelően az iparági összetétel és kiinduló hitelbesorolás is fontos szerepet játszik. A jobb hitelminőségú iparágban a vállalat túlélési valószínúsége nô, míg a rosszabb minôségú társak mellett csökken. Ezek a megfigyelések egybevágnak az empirikus tanulmányok eredményeivel. Jobb iparágban ugyanis a társak leminôsítése javíthatja a vállalat felárát, míg a harmadik csoportban bekövetkezô csôdesemények vagy a társak felminôsítése inkább rontják a vállalat túlélési esélyeit. A 2. csoportban, amely egy átlagos iparágat szimbolizál, a fertőzés hatása a túlélési valószínúségekre szinte elhanyagolható. Továbbá a $p$ paraméter növekedésével minden esetben csökken a fertôzés hatása, hiszen ekkor az események gyorsabban jelentôségüket vesztik.

A fenti eredményeket átültethetjük az árazás területére. Elsőként az egyoldalú hitelértékelési kiigazítást vizsgáltam meg, amely szerint csak az egyik fél tekinthetô kockázatosnak. Jelen számpéldában feltételeztem, hogy egy hipotetikus bank egy 10 év lejáratú 100 névértékú kamatláb csereügyletet köt a vizsgált vállalatokkal. A lehetséges jövóbeli nemteljesítési esemény miatt a bank csökkenti az árat a korábban leírt módon. Az árkiigazítás nagyságát, az egyoldalú hitelértékelési kiigazítás értékét a 3.5. táblázatban adtam meg.

Mivel az egyoldalú hitelértékelési kiigazítás ebben az egyszerú esetben a diszkontált kitettség profil egyes pontjainak csődvalószínûségekkel súlyozott összege, ezért eredményeink párhuzamba állíthatóak a túlélési valószínúségnél már megfigyeltekkel. Az 1. csoport esetén minden kiinduló hitelbesorolás mellett az egyoldalú hitelértékelési kiigazítás mértéke csökkenni fog. A 3. csoportra - ahol a túlélési valószínűség csökkenését figyeltük meg - a CVA nô. Az eltérések a Aa és Baa minőségú partnerekre a legjelentősebbek, ahol $p=0.4$ mellett több mint 
3.2. ábra. Túlélési valószínúségek különbözô kiinduló hitelminősítés és iparági összetétel mellett

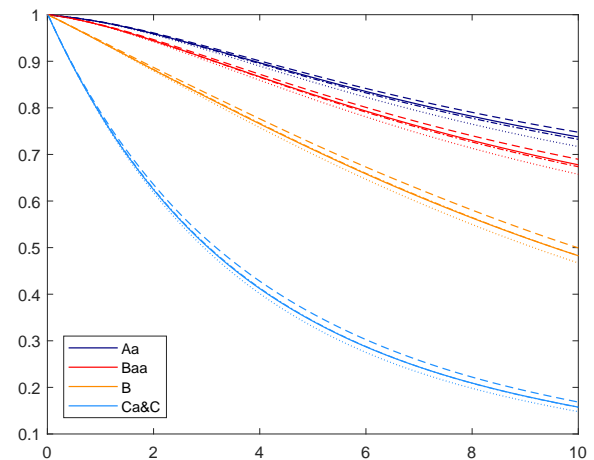

(a) Túlélési valószínúségek $(p=0.4)$

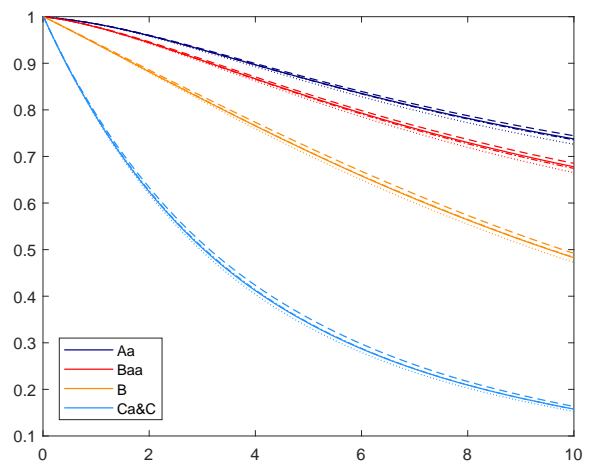

(b) Túlélési valószínúségek $(p=0.7)$

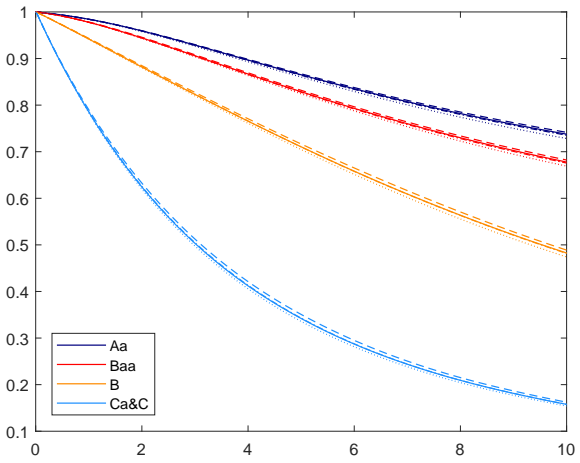

(c) Túlélési valószínúségek $(p=1)$

Magyarázat: A vonalak színei a vállalatok kiinduló hitelbesorolását mutatják, ahogy az ábrákon rögzített jelmagyarázaton látszik. A vonal típusa viszont az iparági összetételt jelenti. Szaggatott vonal (- -) jelenti az 1. csoportba tartozó vállalat túlélési valószínúségét, a vonalból és pontokból (- .) álló a 2. csoportot mutatja, míg a csupa pontozott (. .) vonatkozik a 3. csoportban szereplő vállalatra. Végül a folytonos vonal a fertőzés nélküli túlélési valószínûségeket mutatja. 
3.5. táblázat. Az egyoldalú hitelértékelési kiigazítás értéke különböző feltételek mellett

\begin{tabular}{lcccc} 
& \multicolumn{4}{c}{$p=0.4$} \\
\hline & Aa & Baa & B & Ca\&C \\
\hline Fertőzés nélkül & 0,311 & 0,386 & 0,610 & 1,088 \\
Fertôzéssel - 1. Csoport & 0,299 & 0,371 & 0,585 & 1,068 \\
Fertőzéssel - 2. Csoport & 0,317 & 0,390 & 0,609 & 1,089 \\
Fertőzéssel - 3. Csoport & 0,335 & 0,410 & 0,631 & 1,106
\end{tabular}

\begin{tabular}{lcccc} 
& \multicolumn{4}{c}{$p=0.7$} \\
\hline & Aa & Baa & B & Ca\&C \\
\hline Fertôzés nélkül & 0,311 & 0,386 & 0,610 & 1,088 \\
Fertôzéssel - 1. Csoport & 0,303 & 0,376 & 0,595 & 1,077 \\
Fertôzéssel - 2. Csoport & 0,313 & 0,390 & 0,610 & 1,088 \\
Fertôzéssel - 3. Csoport & 0,324 & 0,401 & 0,625 & 1,099
\end{tabular}

\begin{tabular}{lcccc} 
& \multicolumn{4}{c}{$p=1$} \\
\hline & Aa & Baa & B & Ca\&C \\
\hline Fertőzés nélkül & 0,311 & 0,386 & 0,610 & 1,088 \\
Fertôzéssel - 1. Csoport & 0,306 & 0,380 & 0,600 & 1,080 \\
Fertőzéssel - 2. Csoport & 0,313 & 0,388 & 0,611 & 1,088 \\
Fertőzéssel - 3. Csoport & 0,322 & 0,396 & 0,622 & 1,096
\end{tabular}

6\%-os, de még $p=1$ mellett is 3\%-os eltérések adódnak a fertôzés nélküli esethez képest. A 2. csoport értékei a két eset között maradnak és nem térnek el jelentősen a fertőzés nélküli esettôl. Az egyoldalú CVA esete tehát rávilágít, hogy bizonyos esetekben érdemes tovább vizsgálni a hitelminősítési intézmények bejelentései által generált fertôzô hatásokat. Ezért most tovább lépünk és a kétoldalú hitelértékelési kiigazítás elemzését végezzük el.

A kétoldalú CVA esetében mindkét fél fontos szerepet kap, így a hipotetikus bank szerepét lecseréltem egy elemzett vállalatra. A 3.2. ábra eredményeiból már láthatjuk, hogy különösen érdekes eredményt kaphatunk, ha a származtatott termék két oldalán két külön csoportból jövő vállalat áll. Ahogy láttuk a fertôzés bizonyos esetekben növeli, míg más esetekben csökkenti a túlélési valószínúségeket, ezért különösen érdekesek lehetnek azok a megállapodások, amelyek az 1. és a 3. csoport vállalatai között születnek.

A kétoldalú hitelértékelési kiigazítás elsô példájában a kamatláb csereügyletet a 3. csoportban szereplő Baa minősítésú vállalat az 1. csoport különböző besorolású vállalataival kötötte meg. A 3.6. táblázatból látható, hogy a kétoldalú kiigazítás értéke jelentősen változhat $p=0.4$ mellett, de még $p=1$ esetében is szignifikáns eltéréseket látunk. A két befektetésre ajánlott minôsítésû vállalat közötti ügyleten a kétoldalú CVA akár a másfélszeresére is változhat, miközben 
3.6. táblázat. Kétoldalú hitelértékelési kiigazítás - 1. Csoport vs 3. Csoport

\begin{tabular}{|c|c|c|c|c|c|c|c|}
\hline & \multirow[t]{2}{*}{ Fertőzés nélkül } & \multicolumn{6}{|c|}{ Fertőzéssel } \\
\hline & & $p=0.4$ & $p=0.7$ & $p=1$ & $p=0.4(\%)$ & $p=0.7(\%)$ & $p=1(\%)$ \\
\hline \multicolumn{8}{|l|}{ Fedezet nélkül } \\
\hline 1. Csoport - Aa vs 3. Csoport - Baa & $-0,048$ & $-0,084$ & $-0,073$ & $-0,063$ & $177,1 \%$ & $152,2 \%$ & $133,0 \%$ \\
\hline 1. Csoport - B vs 3. Csoport - Baa & 0,337 & 0,287 & 0,304 & 0,314 & $85,2 \%$ & $90,3 \%$ & $93,3 \%$ \\
\hline 1. Csoport - Ca\&C vs 3. Csoport - Baa & 0,897 & 0,861 & 0,873 & 0,881 & $96,0 \%$ & $97,3 \%$ & $98,2 \%$ \\
\hline \multicolumn{8}{|l|}{ Fedezettel } \\
\hline 1. Csoport - Aa vs 3. Csoport - Baa & $-0,010$ & $-0,014$ & $-0,013$ & $-0,011$ & $144,5 \%$ & $126,7 \%$ & $113,7 \%$ \\
\hline 1. Csoport - B vs 3. Csoport - Baa & 0,044 & 0,038 & 0,040 & 0,042 & $86,4 \%$ & $90,6 \%$ & $94,6 \%$ \\
\hline 1. Csoport - Ca\&C vs 3. Csoport - Baa & 0,142 & 0,136 & 0,138 & 0,140 & $95,9 \%$ & $97,1 \%$ & $98,4 \%$ \\
\hline
\end{tabular}

Megjegyzés: A bemutatott kétoldalú hitelértékelési kiigazítás értékei a sorszerinti elsô vállalat szemszögéból vannak számolva.

3.7. táblázat. Kétoldalú hitelértékelési kiigazítás - 2. Csoport vs 1. Csoport

\begin{tabular}{lccccccc}
\hline & Fertózés nélkül & \multicolumn{7}{c}{ Fertôzéssel } \\
& & $\mathrm{p}=0.4$ & $\mathrm{p}=0.7$ & $\mathrm{p}=1$ & $\mathrm{p}=0.4(\%)$ & $\mathrm{p}=0.7(\%)$ & $\mathrm{p}=1(\%)$ \\
\hline Fedezet nélkül & & & & & & & \\
\hline 2. Csoport - Baa vs 1. Csoport - Aa & $\mathbf{0 , 1 0 4}$ & 0,116 & 0,115 & 0,110 & $111,9 \%$ & $110,9 \%$ & $105,5 \%$ \\
2. Csoport - B vs 1. Csoport - Aa & $\mathbf{0 , 3 9 5}$ & 0,404 & 0,401 & 0,402 & $102,4 \%$ & $101,5 \%$ & $101,9 \%$ \\
2. Csoport - Ca\&C vs 1. Csoport - Aa & $\mathbf{0 , 9 4 0}$ & 0,951 & 0,946 & 0,944 & $101,2 \%$ & $100,6 \%$ & $100,4 \%$ \\
\hline Fedezettel & & & & & & & \\
\hline 2. Csoport - Baa vs 1. Csoport - Aa & $\mathbf{0 , 0 0 9}$ & 0,010 & 0,010 & 0,009 & $116,6 \%$ & $116,0 \%$ & $105,6 \%$ \\
2. Csoport - B vs 1. Csoport - Aa & $\mathbf{0 , 0 5 1}$ & 0,052 & 0,051 & 0,051 & $101,2 \%$ & $100,2 \%$ & $100,6 \%$ \\
2. Csoport - Ca\&C vs 1. Csoport - Aa & $\mathbf{0 , 1 4 8}$ & 0,148 & 0,147 & 0,148 & $100,3 \%$ & $99,7 \%$ & $100,0 \%$ \\
\hline
\end{tabular}

Megjegyzés: A bemutatott kétoldalú hitelértékelési kiigazítás értékei a sorszerinti elsô vállalat szemszögéból vannak számolva.

a másik szerződéseken is jelentôsebb különbségeket látunk, mint az egyoldalú esetben. Megállapíthatjuk tehát, hogy a kétoldalú hitelértékelési kiigazítás kombinálja a javuló és romló túlélési valószínúségeket, amelyek együtt már jelentôs eltéréseket okozhatnak.

Hibás lenne azonban levonni azt a következtetést, hogy a hitelbesorolás változásának fertôzô hatása minden esetben ilyen mértékú. Ennek érdekében feltételeztem egy reálisabb párosítást, ahol az 1. csoport Aa vállalata köt egy megállapodást a 2. csoport más-más minôsítésú szereplőivel. Ilyenkor az esetek többségében nem látunk szignifikáns változást. Ez alól kivételt képez a Baa - Aa közötti kétoldalú hitelértékelési kiigazítás, amely mértéke jelentősen változik a fertôzéssel.

Végül a 3.6. és a 3.7. táblázatokban kiszámoltam a változó letéttel kapott kétoldalú hitelértékelési kiigazítás értékét is. Mint az ismert, a kétoldalú letéti megállapodás csökkenti a hitelértékelési kiigazítás értékét, így abszolút értékben kisebb értékeket mutatunk a táblázatok megfelelő oszlopaiban. Viszont fontos látnunk, hogy a CSA megállapodás megléte nem feltétlen enyhíti a fertőzés szerepét. Pontosabban, nem tudunk megfogalmazni egy általános érvényú megállapítást, mivel ahogy a bemutatott példákon látjuk, a fedezet növelheti és csökkentheti is a fertôzés hatását. 
A bemutatott példák tehát arra mutatnak rá, hogy a hitelminôsítôi bejelentéseket követô fertôzô hatások nem minden esetben hagyhatók figyelmen kívül a hitelértékelési kiigazítás számítása során. Amennyiben a szerződő felek olyan iparágakban szerepelnek, ahol a hitelbesorolások jelentôs koncentrációja figyelhetô meg, akkor a kétoldalú hitelértékelési kiigazítás számításakor fontos a hitelminôsítői bejelentések fertôző hatásait figyelembe venni. Az egyoldalú CVA csak akkor tér el jelentősen, ha az fertőző hatások perzisztensek.

Azokban az iparágakban azonban, ahol a hitelminősítések egyenletesen oszlanak meg a fertôző hatások elhanyagolhatóak. Ilyenkor a hitelminôsítési változások hajlamosak kioltani egymás hatását, ezért a partnerkockázat mérésekor sem okoznak jelentős hatást.

\section{5. Összefoglalás}

A hitelminősítő intézmények bejelentéseinek információtartalma az empirikus szakirodalom régóta vitatott témája. Egyes szerzók szerint a piacok már korán felkészülnek a bejelentésre, míg újabb tanulmányok rámutatnak, hogy bizonyos piaci faktorok reagálnak a hitelminôsítői bejelentésre. Többek között ilyen piaci faktor az érintett és a nem érintett vállalatok CDS felárai. Ebben a fejezetben azt vizsgáltam meg, hogy hogyan hatnak ezek a változások a hitelértékelési kiigazításra.

Elsôként bevezettem a fertőzô csődesemények egy általánosítását, amely magába foglalja a le- és felminôsítések hatását az érintett vállalatra és annak társaira. Mivel a modell örökölte a körkörös csődesemények problémáját, ezért szükség volt egy eljárásra, amellyel csődeseményeket szimulálhattam. Erre a problémára a Yu (2007) által fejlesztett teljes hazard építési módszer egy általánosított verzióját adtam válaszul. Végül egy numerikus példát használva elemeztem a hitelminősítési kategóriában bekövetkezô változások számszerúsített hatását az egyés kétoldalú hitelértékelési kiigazításra. Eredményeim azt mutatják, hogy a hitelbesorolásban bekövetkezô változások hatása nem minden esetben elhanyagolható.

Olyan iparágakban, ahol a hitelbesorolások jobban koncentrálódnak, a csődvalószínüségek jelentôsen változhatnak. Ezek kihatnak az egyoldalú hitelértékelési kiigazítás értékére és vagy növelik, vagy csökkentik azt. Amennyiben azonban a hitelminősítői bejelentések hatásainak időbeli perzisztenciáját csökkentjük, akkor az egyoldalú hitelértékelési kiigazításban látott eltérések is eltúnnek. Valamelyest másként reagál a kétoldalú hitelértékelési kiigazítás, amely aggregálja a partnerek csődvalószínüségében bekövetkezô változásokat. Emiatt ez akár kevésbé tartós hatások mellett is jelentősen változhat a fertôzés bevezetésével. Ez a megfigyelés fedezet mellett is igaz.

Más esetekben, ahol az iparág összetétele a hitelminősítői kategóriák tekin- 
tetében egyenletesebb, a hitelbesorolásokból bekövetkező fertôzô hatások sokkal gyengébbek. Így ekkor nem figyeltem meg jelentôs változást a hitelértékelési kiigazítás értékében.

Az előző és a jelen fejezetben a hitelértékelési kiigazítást annak komponensein keresztül vizsgáltam meg. Foglalkoztam a kitettség és csődvalószínúségek modellezésének és meghatározásának kérdéséivel, valamint megpróbáltam néhány problémát és azok megoldásait részletesen ismertetni. Nyilvánvaló azonban, hogy e komponensek dinamikussá teszik a hitelértékelési kiigazítást, azaz azok változása a CVA értékének ingadozását okozzák. Amennyiben a hitelértékelési kiigazítás értéke fluktuál, akkor az kockázatot jelent. Mint ismert, a bankok legfóbb kockázataikra tôkét kell, hogy képezzenek, ami alól a hitelértékelési kiigazítás sem kivétel. A dolgozat következő fejezetében a szabályozói CVA, azaz a hitelértékelési kiigazítás miatti tôketartalékolás témájának elemzésével ölelem egybe a hitelértékelési kiigazítást és komponenseit. 


\section{4. fejezet}

\section{A hitelértékelési kiigazítás tôketartalékolásának új szabályozása}

A hitelértékelési kiigazítás (CVA) szakirodalmában az egyik legtöbbet idézett mondat a Bázeli Bankfelügyeleti Bizottságtól származik, és magyar fordításban a következőképpen hangzik:

„A globális pénzügyi válság alatt a partnerkockázathoz kapcsolódó veszteségek közel kétharmada a hitelértékelési kiigazítás értékének megváltozásából adódott, és csupán azok egyharmada volt tényleges csődeseményeknek betudható.'11

A mondat jól illusztrálja a hitelértékelési kiigazítás relevanciáját, így szokás azt a CVA számítását elemzô munkákban is feltüntetni. Ugyan az idézetre támaszkodó gyakori érvelés, miszerint a CVA pontos meghatározása a hozzá kapcsolódó veszteségek miatt különös fontossággal bír, elfogadható gondolatnak tekinthető, azonban eredetileg a Bázeli Bankfelügyeleti Bizottság egy másik fontos szempontot kívánt azzal megmutatni. Ezt az adatot ugyanis a CVA változásából adódó veszteségek elleni szabályozói tókeszükséglet bevezetésének indoklására használták a Bázel 3 szabályozói keretrendszer publikálásakor. Az OTC derivatívák tôketartalékolásának szabályozói motivációjáról az 1.3.2. fejezetben írtam.

A CVA tôkeképzés mára már általánosan elfogadott eljárássá nôtte ki magát. A jelenleg hatályban lévô rendszer szerint egy fejlett és egy standard formula alapján kell tôkét képezni.2

A Bázeli Bankfelügyeleti Bizottság 2015. júliusában azonban kiadott egy tervezetet a jövôbeli CVA tókeképzés keretéról. A BCBS (2015) javaslata annak

1 „During the global financial crisis, however, roughly two-thirds of losses attributed to counterparty credit risk were due to CVA losses and only about one-third were due to actual defaults." http://www.bis.org/press/p110601.htm

${ }^{2}$ A jelenlegi Bázel 3 néven emlegetett szabályozást a BCBS (2011) dokumentuma részletezi. 
ellenére, hogy számos ponton kiegészíti, valamint javítja elôdjét, mégsem aratott felhôtlen sikert. A válság óta óriási tôkebevonáson átesett és gyakran már túlszabályozottnak kikiáltott bankrendszer érthetóen nagy óvatossággal fogadja a tôkeszükségleteket érintő új szabályokat. Így nem meglepő például az ISDA levelét olvasni, akik az új módszert kritizálva többek között az alábbi elvárásokat fogalmazták meg ${ }^{3}$ :

- A szabályozói CVA számviteli társával történő jobb összeegyeztetése.

- A fedezeti ügyletek és további árkiigazítások figyelembevétele a tőkeszükséglet szabályozásban.

- Az alap CVA módszer kockázati súlyainak és paramétereinek újrakalibrálása és azok hitelkockázat érzékenységének javítása.

- A belsô modellen alapuló számítás teljesítményének teszteléséhez kapcsolódó további magyarázat és a modellkockázati paraméter újrakalibrálása.

Az új CVA tőkeszabályozás körüli feltüzelt helyzetet a Bázeli Bankfelügyeleti Bizottság újabb lépéseivel csak tovább fútötte. 2016. februárjában egy QIS4 gyakorlat keretein belül egy valamelyest átdolgozott szabályozás hatásait szerették volna vizsgálni. A QIS során három módszer állt rendelkezésre: egy belsô modellezésen alapuló fejlett módszer, egy érzékenységen alapuló standardizált formula, és egy kisbankoknak célzott alap, standardizált megközelítés. Egy hónappal később egy új közleményben váratlanul eltörölték a CVA-IMA fejlett módszert, arra hivatkozva, hogy az új kötelező kétoldalú fedezeti szabályozás és a központi klíring csökkenti a CVA kockázatot, így nincs szükség bonyolult belsô modellezésen alapuló szabályozásra (BCBS, 2016c). A döntés iparági fogadtatása ismét negatív volt, hiszen a standardizált súlyok sokkal konzervatívabbak, mint a kockázatra ténylegesen érzékeny belsô modell alapú megközelítés. Voltak, akik kiemelték, hogy a Bázeli Bankfelügyeleti Bizottság által hozott érv valójában nem mérvadó, hiszen a portfóliójuk jelentős részét nem érinti a kétoldalú kötelező fedezeti szabályozás (Wood, 2016). Érdekes módon a QIS-hez kiadott BCBS (2016a) dokumentumban továbbra is azt kérték, hogy a résztvevook az IMA módszerhez tartozó részeket is töltsék ki.

Így két megközelítés maradt a szabályozók eszköztárában: az érzékenység alapú (SA) és az alap (Basic) CVA. Korai spekulációk alapján az érzékenység alapú módszer a kereskedési könyv várható új szabályozása ${ }^{5}$ miatt, míg az alap CVA

${ }^{3} \mathrm{Az}$ ISDA levele elérhetô az alábbi linken: http://www.bis.org/bcbs/publ/comments/d325/ igijr.pdf

${ }^{4}$ Quantitative Impact Study - A Bizottság standard módszere az új szabályozások hatásának tesztelésére.

${ }^{5}$ A javaslatot gyakran FRTB néven szokás említeni az angol címe alapján: Fundamental Review of the Trading Book. (BCBS, 2016b) 
módszer a kevésbé fejlett bankok korlátai miatt feltételezhető, hogy része lesz a végső BCBS javaslatnak (Sherif, 2016). A Bázeli Bankfelügyeleti Bizottság végül 2017 decemberében publikálta a szabályozás végső változatát, amelyben mindkét módszer helyet kapott. Jelen munka tárgya az alap CVA módszer.

A bázeli javaslat az alap CVA módszerre ,,a standard módszer javított verziója”ként hivatkozik. Valójában az új alap CVA módszer mögött a korábbi standardizált módszer húzódik meg. Pykhtin (2012) munkája egy általános modellkeretet ad meg, amelyből a standard módszerhez tartozó szabályozói formulák származtathatóak. Ebben a fejezetben az alap CVA módszert elemzem, követve annak történetét a Bizottság által publikált változatok sorrendjében. Elsóként bemutatom az új módszert és megvizsgálom, hogy az pontosan mely pontokon is javított elődjén. Ezután Pykhtin (2012) módszertanából kiindulva, majd kiegészítve azt rámutatok, hogy pontosan milyen analitikus modell is áll az alap CVA formula mögött ${ }^{6}$ Végül numerikus teszteken vizsgálom a két módszert, és néhány példán keresztül kiemelek számos fontos eredményt.

Rámutatok, hogy az új alap CVA szabályozás bizonyos helyzetekben konzervatívabbnak tekinthető elődjénél, és ennek szintjét a korrelációs paraméter függvényében elemzem. Továbbá megvizsgálom a fedezeti ügyletek szerepét. Ugyan az új szabályozás közelebb hozza a tökéletesen fedezett portfóliót a nulla tôkeszükségletű portfólióhoz, azonban ezek még mindig nem esnek egybe. Ebból adódóan viszont bizonyos helyzetekben az alap CVA módszer korai formája kisebb tôkeszükségletet ad eredményül, mint azt a kiinduló modell tenné. Mivel idóközben a véglegesített változat is elérhetôvé vált, ezért ismertetem az alap CVA formula végsô alakját, és rámutatok, hogy az általam megfogalmazott kritikákat ez az alak részben kezeli, míg más esetekben további kérdéseket vet fel.

Azontúl, hogy a fejezet követi a dolgozat alulról felfelé épülő struktúráját, további szempontból is keretet képez a disszertációnak. Figyelem elótt tartva a dolgozat egyik fô célját - miszerint a hitelértékelési kiigazítás egy átfogó leírását szeretném elkészíteni - az egyes fejezetekben különbözô szemszögból vizsgálom a partnerkockázat árazását. A 2. fejezetben a bankok, avagy a felhasználók technikai kérdéseivel foglalkoztam. A 3 fejezetben egy figyelmen kívül hagyott kockázati tényezô elemzését végeztem el, amely mind a hitelértékelési kiigazítást számító felek és mind pedig a szabályozók szempontjából releváns kérdés. Ebben a fejezetben befejezve a fokozatos átmenetet, egyértelmúen a szabályozók gondolkodásmódját, és CVA általuk látott arcát vizsgálom meg.

A fejezet felépítése a következő: A következô részben bemutatom a bázeli CVA tôkeszükséglet alapfogalmait, majd ismertetem az alap CVA módszert. Ezután megmutatom, hogy egy egyszerü faktormodellból kiindulva hogyan is juthatunk

${ }^{6}$ A fejezet Boros (2018a) tanulmányomon alapul. 
el a szabályozói formuláig. A 4.3. alfejezetben numerikus teszteket futtatok hipotetikus portfóliókon és megvizsgálom a formula viselkedését, és annak az alapmodelltôl való eltérésének okait. Ezután ismertetem az alap CVA formula utolsó változatát. A 4.5. alfejezetben összefoglalom a tapasztalatokat.

\subsection{Tóketartalékolás az alap CVA módszer szerint}

Az új CVA tókeszükséglet számítás bemutatása elôtt röviden bevezetem a partnerkockázati tőketartalékolás legfontosabb fogalmait. Az ezek megértéséhez szükséges fogalmakat és jelöléseket röviden itt is ismertetem, de részletesebb leírást az 1. fejezetben találhat az Olvasó.

Hasonlóan a korábbi fejezetekhez tegyük fel, hogy $B$ és $C$ megköt egy $T$ idôpontban lejáró derivatív szerződést. Ha feltételezzük, hogy $B$ és $C$ partnerkockázat mentesek, azaz sohasem csődölhetnek, akkor jelölje $\Pi(t, T)$ az általuk kötött derivatív ügylet $t$ és $T$ közötti diszkontált pénzáramainak az összegét $B$ szemszögéból. Így a következóképpen definiálhatjuk a derivatív $t$-ben vett árát:

$$
V(t)=\mathbb{E}_{t}[\Pi(t, T)]
$$

ahol $\mathbb{E}_{t}[]=.\mathbb{E}\left[. \mid \mathcal{F}_{t}\right]$ azaz az $\mathcal{F}_{t}$ filtrációra vett, kockázatsemleges mérték szerinti feltételes várható érték.

Amennyiben a felek a derivatív élettartama során fizetésképtelenné válhatnak, akkor egy csődeseménykor a túlélő fél köteles minden tartozását megfizetni a fizetésképtelen partnernek, míg követelésein veszteséget fog elszenvedni. Jelölje $R E C_{i}$ a partnerek nemteljesítésekori megtérülési rátát, ahol $i \in\{B, C\}$ és $0 \leq$ $\leq R E C_{i} \leq 1$. Ahogy korábban is, a megtérülés helyett jellemzően a veszteséget fogom használni, azaz az $L G D_{i}=1-R E C_{i}$ jelölést vezetem be.

Egy egyszerú esetben a $t$ időpontban a derivatív piaci értékének pozitív része a kitettség, azaz:

$$
E(t)=\max (0, V(t))=(V(t))^{+} .
$$

Ezt felhasználva definiálható a várható pozitív kitettség profil:

$$
E E(t)=\mathbb{E}^{x}[E(t)]=\mathbb{E}^{x}\left[\left(\mathbb{E}_{t}[\Pi(t, T)]\right)^{+}\right]
$$

A számítás céljától függóen a külsô $\mathbb{E}^{x}[$.$] várható érték ebben az esetben jelenthe-$ ti a kockázatsemleges és a valós mérték alatt vett várható értéket is. Így például partner limitek meghatározásához a valós mérték alatt, míg a hitelértékelési kiigazítás számításakor a kockázatsemleges mérték alatt kell számolni. Most már megadhatjuk az így kapott profil lejáratig vett súlyozott átlagát, amit szokás hitel-egyenértékesnek is hívni és egy $0=t_{0}<t_{1}<t_{2}<\ldots<t_{m-1}<t_{m}=T$ 
felosztáson közelíteni :

$$
E P E=\frac{1}{T} \int_{0}^{T} E E(t) d t \approx \frac{1}{T} \sum_{i=1}^{m} E E\left(t_{i}\right)\left(t_{i}-t_{i-1}\right) .
$$

A szabályozói tôketartalékolásban felhasznált nemteljesítéskori kitettséghez az elsố évhez tartozó, nemcsökkenô $E E(t)$ profilt kell használni, így kapjuk az effektív várható pozitív kitettség fogalmát:

$$
E E P E=\sum_{i=1}^{m^{\prime}} \max _{j \leq i}\left\{E E\left(t_{j}\right)\right\}\left(t_{i}-t_{i-1}\right),
$$

ahol $t_{m^{\prime}}=1$. A bázeli szabályok tókeszükséglet képletének egyik fontos bemeneti paramétere a nemteljesítéskori kitettség $(E A D)$, ami a fentiek alapján a következő formában áll elő:

$$
E A D=\alpha E E P E
$$

ahol $\alpha$ egy szabályozói paraméter, jellemzően $\alpha=1.4$. A kitettség profilok alapján a lejáratot is átsúlyozhatjuk, így eljutva az effektív lejárat fogalmához:

$$
M_{e f f}=1+\frac{\sum_{k>m^{\prime}}^{m} E E\left(t_{i}\right)\left(t_{i}-t_{i-1}\right) D\left(0, t_{i}\right)}{\sum_{i=1}^{m^{\prime}} \max _{j \leq i}\left\{E E\left(t_{j}\right)\right\}\left(t_{i}-t_{i-1}\right) D\left(0, t_{i}\right)},
$$

ahol $D(t, T)$ jelöli a t és T közötti diszkontfaktort.

Végül definiáljuk a hitelértékelési kiigazítást. A bázeli szabályok az egyoldalú hitelértékelési kiigazítást fogadják el, amely szerint a kiigazítást számító fél csődkockázatát figyelmen kívül kell hagyni. A fentiek alapján a hitelértékelési kiigazítást az alábbi komplex formában definiálhatjuk, amit célszerú rögtön egy jobban áttekinthetô alakra egyszerúsíteni:

$$
\begin{aligned}
C V A & =\mathbb{E}\left[L G D 1_{(t<\tau \leq T)} D(0, \tau)\left(\mathbb{E}_{\tau}[\Pi(\tau, T))^{+}\right] \approx \sum_{i=1}^{m} \mathbb{E}\left[L G D 1_{\left(t_{i-1} \leq \tau<t_{i}\right)} D\left(0, t_{i}\right)\left(V\left(t_{i}\right)\right)^{+}\right]\right. \\
& =\sum_{i=1}^{m} L G D \mathbb{E}\left[1_{\left(t_{i-1} \leq \tau<t_{i}\right)}\right] \mathbb{E}\left[D\left(0, t_{i}\right)\left(V\left(t_{i}\right)\right)^{+}\right]=\sum_{i=1}^{m} L G D \mathbb{Q}\left(t_{i-1}<\tau \leq t_{i}\right) E E^{*}\left(t_{i}\right),
\end{aligned}
$$

ahol elsố lépésként a fentebb megadott $0=t_{0}<t_{1}<t_{2}<\ldots<t_{m-1}<t_{m}=$ $=T$ időfelosztáson közelítettem a számítást, majd feltételeztem a csôdesemény és kitettség függetlenségét. Végül bevezettem a kockázatmentes csődvalószínúség $\left(\mathbb{Q}\left(t_{i-1} \leq \tau<t_{i}\right)\right)$ és a diszkontált kitettség profil $\left(E E^{*}\left(t_{i}\right)\right)$ jelöléseket. Az így kapott mennyiségre szokás számviteli CVA-ként hivatkozni, hiszen ez a tényezô a kockázatmentes árat csökkenti.

A Bázeli Bankfelügyeleti Bizottság BCBS (2015) javaslata alapján az új standardizált, hivatalos nevén alap CVA tókeszámítási módszert választó intézményeknek az alábbi formula szerint kell tőkét képezni a hitelértékelési kiigazítás mozgásából adódó veszteségekre:

$$
K=K_{\text {spread }}+K_{E E},
$$


ahol $K$ jelenti a szabályozói tőke nagyságát és

$$
\begin{aligned}
K_{\text {spread }}= & {\left[\left(\rho \sum_{c}\left(S_{c}-\sum_{h} r_{h c} S_{h}^{S N}\right)-\sum_{i} S_{i}^{\text {ind }}\right)^{2}\right.} \\
& \left.+\left(1-\rho^{2}\right) \sum_{c}\left(S_{c}-\sum_{h} r_{h c} S_{h}^{S N}\right)^{2}+\sum_{c} \sum_{h}\left(1-r_{h c}^{2}\right)\left(S_{h}^{S N}\right)^{2}\right]^{\frac{1}{2}},
\end{aligned}
$$

valamint

$$
K_{E E}=0.5\left[\left(\rho \sum_{c} S_{c}\right)^{2}+\left(1-\rho^{2}\right) \sum_{c} S_{c}^{2}\right]^{\frac{1}{2}} .
$$

A szabályozói tőkeszükséglet tehát két tagból tevődik össze. Ahogy azt hamarosan megmutatom, az elsô tag $\left(K_{\text {spread }}\right)$ a partnerek hitelfelárának elmozdulásából adódó veszteség ellen tókésít. A második tagnak $\left(K_{E E}\right)$ az egyoldalú hitelértékelési kiigazítás másik fontos inputjának, a kitettség profilok megváltozásának hatását kellene számszerúsítenie, azonban sokkal közelebb áll az első taghoz.

A formulák megértéséhez vegyük végig az egyenletben szereplő egyes tagokat. A partnereket $c$, a hedgeket $h$ és az index hedgeket $i$ indexek jelölik. Az $S_{c}$ a $c$ partner felé fenálló kitettség nagyságát számszerúsíti az alábbi formában:

$$
S_{c}=\frac{R W_{b(c)}}{\alpha} \sum_{n s \in c} M_{n s} E A D_{n s}
$$

ahol $M_{n s}$ és $E A D_{n s}$ a $c$ partnerhez tartozó ns nettósítási csoporthoz rendelt effektív lejárat és nemteljesítéskori kitettség. Egy nettósítási csoport a partnerrel kötött olyan ügyletek összessége, amelyek egymással történô nettósítása engedélyezett. A fejezetben az egyszerúség kedvéért partnerenként egy ügyletet tételezek fel. Így nincs szükség a nettósítási csoport definíciójára, de az általam leírt eredmények ugyanúgy igazak azon a szinten is. Végül az $R W$ egy, a szabályozó által előírt súly, amelyet hamarosan ismertetek és az $\alpha$ a már korábban bevezetett szabályozói paraméter.

A kitettség és így a tôkeszükséglet két típusú lehetséges fedezeti eszközzel csökkenthető: Egy referencia névre szóló hitelmulasztási ügylettel (CDS) vagy index hedge segítségével. A $h$ vállalatra szóló hitelmulasztási csereügylet által kínált védelem $S_{h}$ formában jelenik meg, ahol:

$$
S_{h}^{S N}=R W_{b(h)} M_{h}^{S N} B_{h}^{S N} .
$$

A fenti formulában $M_{h}^{S N}$ jelenti a CDS lejáratát és $B_{h}^{S N}$ a diszkontált névértékét, azaz

$$
B_{h}^{S N}=B \frac{1-e^{-0.05 M_{h}^{S N}}}{0.05 M_{h}^{S N}},
$$




\section{1. táblázat. Korrelációs paraméterek}

\begin{tabular}{cll} 
Paraméter & A hedge és a partner kapcsolata & Paraméter értéke \\
\hline \multirow{2}{*}{$r_{h c}$} & $\begin{array}{l}\text { A partnerre vásárolt hedge esetén } \\
\text { A hedge egy másik félre szól, }\end{array}$ & $100 \%$ \\
& $\begin{array}{l}\text { de annak jogi kapcsolata van a partnerrel } \\
\text { A hedge egy másik félre szól, }\end{array}$ & \\
& $\begin{array}{c}\text { de az eredeti partnerrel megegyezó } \\
\text { szektorban és régióban tevékenykedik }\end{array}$ & $50 \%$ \\
\hline$\rho$ & & $50 \%$ \\
\hline
\end{tabular}

ahol $B$ a CDS névértéke. A hitel indexekre vásárolt hedge a 4.13 , egyenlethez teljesen hasonló formában írható fel, azzal a különbséggel, hogy a lejárat és a névérték paraméterek a CDS indexre vonatkoznak. A dolgozatban eltekintek az ilyen típusú fedezeti ügyletektôl, azaz a 4.10 . egyenletben $S_{i}^{i n d}=0$ választással élek.

A $\rho$ és $r_{h c}$ szabályozói korrelációs paraméterek, amelyek értéke a 4.1. táblázatban látható. Ennél a pontnál már világosan látszik, hogy $K_{E E}=0.5 K_{\text {spread }}$ feltéve, hogy nem használunk fedezeti ügyleteket.

A formula ugyan hasonló a jelenleg hatályban lévô standardizált képlethez, azonban számos téren különbözik attól. A bázeli javaslat is ,,a standard módszer javított verziója"-ként hivatkozik az alap CVA formulára.7 A legszembetûnóbb változás, hogy a hitelfelárak mozgásából adódó változások mellett már a kitettség értékének megváltozására is tôkét $\left(K_{E E}\right)$ kell képezni. A kitettség mozgásából adódó veszteség eddig egy figyelmen kívül hagyott tényezô volt, így az új CVA formula valóban javíthatott volna az elődjén, ha a kitettség változása megfelelően kerül tôkésítésre. Valójában azonban egy, a kitettség profil tényleges változására egyáltalán nem érzékeny, konzervatív érték szerepel a javaslatban.

A második legfontosabb eltérés, hogy a figyelembe vehetô fedezeti ügyletek halmaza bóvült. Szemben a korábbi gyakorlattal, miszerint csak a partnerre szóló hitelmulasztási ügyletek az elfogadottak, most a partnerrel egy szektorban és régióban tevékenykedő vállalatokra szóló, proxy hedgek is beszámíthatók a tókeszámításba. Az ezekből származó előny értelemszerúen büntetve, az $r_{h c}$ faktoron keresztül jelenik meg a formulában. A $K_{E E}$ formula jellegéból adódóan a kitettség profil mozgását fedezô tranzakciók továbbra sem járulnak hozzá a CVA tôkeszükséglet csökkentéséhez.

Továbbá a 4.12 egyenletben az $\alpha$ faktorral osztott $E A D$ jelenik meg, amely jelentôs lépés a szabályozói és a számviteli CVA összehangolása felé. Ez különös szereppel bír a fedezés szempontjából, hiszen a korábbi keretrendszer mellett a

${ }^{7}$,The Basic CVA framework consists of a single Basic CVA approach (BA-CVA) that is essentially an improved version of the current Standardised CVA method.' $\mathrm{BCBS}(2015)$ 
tôketartalékot képző felek, ha a szabályozói tőkeszükségletük szerint fedezték a hitelértékelési kiigazítást, akkor nagyobb veszteséget generálhattak maguknak, mert a két módszer nem volt összehangolva. Carver 2013) munkája alapján láthatjuk, hogy nem csupán egy elméleti problémáról van szó, hiszen a Deutsche Bank tőkeszükségleteinek csökkentése miatt kénytelen volt elszenvedni egy 94 millió eurós veszteséget. Ahogy hamarosan megmutatom, az új módszer javítása nem oldja meg teljesen ezt a problémát.

Az új CVA tóketartalékolási keretrendszer egyik célja, hogy a manapság gyakran elôtérbe kerülő, a kereskedési könyv átfogó reformjaként 8 nevezett új szabályozással összhangban álló módszertant teremtsen. A reform ugyan számos téren jelentôs újításokat vezet be, de talán az egyik leggyakrabban emlegetett változás a kockáztatott érték (VaR) kockázati mérték Expected Shortfall-ra (ES) történő cseréje. Ezzel összhangban, a CVA tóke is egy ES alapú mutató eredménye lesz, amely szignifikancia szintjét 97.5\%-os értéknél határozták meg.

Végül, a standardizált $R W$ paramétereket is újrakalibrálták. Így már nem közvetlenül a partner hitelminôsítési osztálya adja meg a formulában használandó súlyt, hanem egy kettős, a befektetési minősítésen és a partner tevékenységét leíró szektoron alapuló hozzárendelés dönti el annak nagyságát. A formula egyes elemeinek megismerése után a következő részben a szabályozói formula mögött meghúzódó modell levezetésével folytatom.

\subsection{Az alap formula modellkerete}

A 4.10 egyenletben szereplő kifejezések valójában egy egyszerú modellból kapott veszteségek, a szabályozók által megadott szignifikancia szint melletti kockázati mértékei. Az új CVA tókeszabályozás alapjai a jelenleg hatályban lévô standard szabály mögött meghúzódó modellen nyugszanak, amit Pykhtin (2012) vázolt fel részletesen. Ebben a részben ezért erôsen támaszkodok Pykhtin (2012) munkájára, és néhány ponton kiegészítem azt, hogy végül az új szabályozás mögötti modellkerethez jussak el.

Az új tôkeszükséglet szabályozás továbbra is csak az egyoldalú hitelértékelési kiigazítást használja, ami az árat számoló felet kockázatmentesnek tekinti. Először szükség van a 4.8 egyenletben használt csődvalószínüségek formalizálására. Ehhez egy egyszerú redukált formájú modellt használok, ahol

$$
\mathbb{Q}(\tau>t)=e^{-\lambda t}
$$

és $\lambda$ a $\tau$ csődidôponthoz tartozó intenzitás, vagy hazard ráta. Az Olvasó a redukált formájú csődmodellekrôl az1 fejezetben talál részletes leírást. Tegyük fel, hogy az

8 BCBS, 2016b 
i. partnerrel kötött derivatívák közül a leghosszabb lejárata $T^{i}$. Ekkor a $0=t_{0}^{i}<$ $<t_{1}^{i}<\ldots<t_{N}^{i}=T^{i}$ közelítéssel a partnerhez tartozó egyoldalú hitelértékelési kiigazítást az alábbi formában számolhatjuk:

$$
\begin{aligned}
& C V A=\sum_{k=1}^{N} L G D \mathbb{Q}\left(t_{k-1}^{i}<\tau \leq t_{k}^{i}\right) E E^{*}\left(t_{k}^{i}\right)=\sum_{k=1}^{N} L G D\left(e^{-\lambda_{i} t_{k-1}^{i}}-e^{-\lambda_{i} t_{k}^{i}}\right) E E^{*}\left(t_{k}^{i}\right) \\
& =\sum_{k=1}^{N} L G D\left(e^{-\lambda_{i} t_{k}^{i}} e^{-\lambda_{i}\left(t_{k-1}^{i}-t_{k}^{i}\right)}-e^{-\lambda_{i} t_{k}^{i}}\right) E E^{*}\left(t_{k}\right)=\sum_{k=1}^{N} L G D\left(e^{-\lambda_{i} t_{k}^{i}}\right)\left(e^{\lambda_{i}\left(\Delta t_{k}^{i}\right)}-1\right) E E^{*}\left(t_{k}^{i}\right) .
\end{aligned}
$$

A fenti egyenletet Pykhtin (2012) annak elsôrendú Taylor közelítésével helyettesíti, és ezt a mennyiséget tekinti a tôketartalékolási szabály alapjának. Ha felhasználjuk, hogy $\frac{s_{i}}{L G D_{i}} \approx \lambda_{i}$, ahol $s_{i}$ a partner hitelfelára, akkor az egyszerúsített hitelértékelési kiigazítást az alábbi formájában adhatjuk meg:

$$
C V A_{i}=s_{i} \sum_{k=1}^{N} E E_{i}^{*}\left(t_{k}^{i}\right) \Delta t_{k}^{i} e^{-s_{i} t_{k}^{i} / L G D_{i}} .
$$

A bázeli szabályozással összhangban feltételezem, hogy a hitelértékelési kiigazítás fedezésére hitelmulasztási ügyletet köthetünk. Ha a hedge lejárata $\widehat{T}^{j}$, akkor az értékét $0=t_{0}^{j}<t_{1}^{j}<\ldots<t_{N^{\prime}}^{j}=\widehat{T}^{j}$ intervallum felosztás mellett, Pykhtin (2012) alapján a következő formában adhatjuk meg:

$$
C D S_{j}=B_{j}\left(s_{j}-s_{j}^{c o n t r}\right) \sum_{k=1}^{N^{\prime}} D\left(0, t_{k}^{j}\right) \Delta t_{k}^{j} e^{-s_{j} t_{k}^{j} / L G D_{j}},
$$

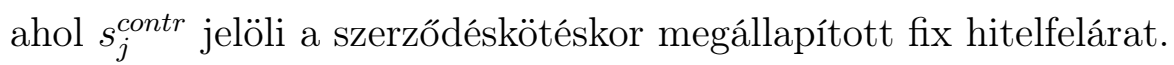

A jelenleg hatályban lévô CVA tókeszabályozás csakis a partnerre szóló hitelmulasztási ügyleteket fogadja el, azaz a fenti CDS csak akkor elfogadható fedezet, ha $i=j$ a fenti két egyenletben. Mivel az új javaslat enyhít ezen a szabályozáson és nem-tökéletes, proxy hedgeket is elfogad, ezért külön indexet használok a partnerre illetve a hedge referencia nevére. Egy partnert többféle eszközzel is fedezhetünk, így jelölje $C D S^{\text {portfolio }}(i)$ az $i$. partner fedezésére használt hitelmulasztási ügyletek portfóliójának értékét. Azaz ha Hedge(i) az $i$. partner hedgelésére használt nevek indexei, akkor:

$$
C D S^{\text {portfolio }}(i)=\sum_{j \in \operatorname{Hedge}(i)} C D S_{j}
$$

A hitelértékelési kiigazítás a kockázatmentes árból levont mennyiség, tehát növekedése veszteséget jelent az azt számoló félnek.9 Így a fedezett CVA rendelkezik azzal a tulajdonsággal, hogy a megváltozása ellensúlyozva van a fedezô CDS portfólió megváltozásával. A tőketartalék meghatározásakor a fenti derivativákból és a CVA-ból álló teljes portfólió, összes partnerre aggregált értékeire vagyunk

${ }^{9}$ A hitelértékelési kiigazítást szokás egy önálló, komplex derivatívaként is kezelni. 
kíváncsiak. Azaz a

$$
\Delta C V A_{i}-\Delta C D S^{\text {portfolio }}(i)
$$

mennyiség összes partnerre vett értéke határozza meg a szabályozói tôkét. ${ }^{10}$

Pykhtin (2012) rámutat, hogy a hatályos Bázel 3 szabályozásban szereplô standard képlet az így felírt portfolió megváltozásának egy elsôrendú közelítése egy egy-faktoros modell mellett. Kövessük most ezt az elemzést, és írjuk fel az elsôrendû közelítést, azonban engedjük meg a proxy hedgeket a modellben.

Az elsôrendû közelítést alkalmazva a portfólió megváltozása a következô lesz:

$$
\Delta C V A_{i}^{\text {fedezett }}=A_{i} \Delta s_{i}-\sum_{j} \widehat{B_{j}^{i}} \Delta s_{j}
$$

ahol

$$
A_{i}=\frac{\partial C V A_{i}}{\partial s_{i}}=\sum_{k=1}^{N} E E_{i}^{*}\left(t_{k}^{i}\right) \Delta t_{k}^{i} e^{-s_{i} t_{k}^{i} / L G D_{i}}\left(1-s_{i} t_{k}^{i} / L G D_{i}\right)
$$

és

$$
\widehat{B_{j}^{i}}=\frac{\partial C D S_{j}^{i}}{\partial s_{j}}=B_{j}^{i} \sum_{k=1}^{N^{\prime}} D\left(0, t_{k}^{j}\right) \Delta t_{k}^{j} e^{-s_{j} t_{k}^{j} / L G D_{j}}\left(1-s_{j} t_{k}^{j} / L G D_{j}+s_{j}^{c o n t r} t_{k}^{j} / L G D_{j}\right) .
$$

A fenti egyenletben az eredeti $B_{j}$ névértéket $B_{j}^{i}$-re cseréltem, jelezve, hogy a $j$. partnerre vásárolt hitelmulasztási ügyletból mennyi is van használva az $i$. partner fedezésére. Ebból adódóan $\widehat{B_{j}}$ is $\widehat{B_{j}^{i}}$-re változik. Jellemzóen a fenti egyenletben szereplő szumma majdnem összes tagja nulla, hiszen egy partner fedezésére nincs figyelembe véve az összes partnerre szóló fedezeti ügylet, de az általános felírás kedvéért mégis ezt a jelölést alkalmazom. Tételezzük fel, hogy az $s$ hitelfelár az alábbi lognormális eloszlás szerint változik, ahogy azt Pykhtin (2012) is feltételezte:

$$
\Delta s_{i}=s_{i}^{0}\left(e^{\left(-0.5 \sigma_{i}^{2} H+\sigma_{i} \sqrt{H} X_{i}\right)}-1\right) \approx s_{i}^{0} \sigma_{i} \sqrt{H} X_{i}
$$

és

$$
\Delta s_{j}^{(i)}=s_{j}^{0}\left(e^{\left(-0.5 \sigma_{j}^{2} H+\sigma_{j} \sqrt{H} W_{i j}\right)}-1\right) \approx s_{j}^{0} \sigma_{j} \sqrt{H} W_{i j},
$$

ahol $X_{i}$ és $W_{i j}$ normális valószínúségi változók, és $\sigma_{i}$ és $\sigma_{j}$ pedig a megfelelő volatilitások.

${ }^{10}$ Tökéletes fedezés esetén a portfólió megváltozása nulla:

$$
\Delta C V A_{i}-\Delta C D S^{\text {portfolio }}(i)=0
$$

Ilyen esetben tehát a tóketartalékolási formulának elvárható tulajdonsága lenne, hogy egy ilyen portfólióhoz nulla tőkeszükségletet rendeljen. 
Vegyük észre, hogy ennél a pontnál már eltérek Pykhtin (2012) munkájától, hiszen a proxy hedgeket is megengedem a modellben. Tételezzük fel, hogy a hitelfelár mozgását meghatározó tényezők az alábbi faktormodell szerint változnak:

$$
W_{i j}=\xi X_{i}+\sqrt{1-\xi^{2}} V_{j}
$$

és

$$
X_{i}=\rho Z+\sqrt{1-\rho^{2}} Z_{i}
$$

ahol $V_{j}, Z_{i}$ és $Z$ független standard normális változók. A fenti felírással összekötöm a partner és a fedezeti ügylet referencia nevének hitelfelárainak mozgását. Értelemszerúen $i=j$ esetén $\xi=1$ kikötéssel élek.

Ezt a 4.22 . egyenletbe visszahelyettesítve és az összes partnerre aggregálva az alábbi egyenletet kapjuk:

$$
\begin{aligned}
\triangle C V A^{\text {fedezett }}=\sum_{i} \Delta C V A_{i}^{\text {fedezett }}=\sum_{i}\left(A_{i} s_{i}^{0} \sigma_{i} \sqrt{H} X_{i}-\sum_{j} \widehat{B_{j}^{i}} s_{j}^{0} \sigma_{j} \sqrt{H} W_{i j}\right) \\
=\sqrt{H}\left[\sum_{i}\left(\left(A_{i} s_{i}^{0} \sigma_{i}-\sum_{j} \widehat{\xi B_{j}^{i}} s_{j}^{0} \sigma_{j}\right) X_{i}\right)-\sum_{i} \sum_{j} \sqrt{1-\xi^{2}} \widehat{B_{j}^{i}} s_{j}^{0} \sigma_{j} V_{j}\right] \\
=\sqrt{H}\left[\rho\left(\sum_{i}\left(A_{i} s_{i}^{0} \sigma_{i}-\sum_{j} \widehat{B_{j}^{i}} s_{j}^{0} \sigma_{j}\right)\right) Z\right. \\
\left.+\sqrt{1-\rho^{2}} \sum_{i}\left(\left(A_{i} s_{i}^{0} \sigma_{i}-\sum_{j} \xi \widehat{B_{j}^{i}} s_{j}^{0} \sigma_{j}\right) Z_{i}\right)-\sum_{i} \sum_{j} \sqrt{1-\xi^{2}} \widehat{B_{j}^{i}} s_{j}^{0} \sigma_{j} V_{j}\right] .
\end{aligned}
$$

Vegyük észre, hogy az így kapott egyenlet független, standard normális változók lineáris kombinációja. A szögletes zárójelen belül $N+N_{\text {hedge }}+1$ darab független normális valószínúségi változó szerepel. Ez alapján tehát a 4.29. egyenlet előáll a következô alakban:

$$
\Delta C V A^{\text {fedezett }}=\sqrt{H} \beta Y,
$$

ahol

$$
\begin{aligned}
\beta^{2}= & {\left[\rho^{2}\left(\sum_{i}\left(A_{i} s_{i}^{0} \sigma_{i}-\sum_{j} \xi \widehat{B_{j}^{i}} s_{j}^{0} \sigma_{j}\right)\right)^{2}\right.} \\
& \left.+\left(1-\rho^{2}\right) \sum_{i}\left(\left(A_{i} s_{i}^{0} \sigma_{i}-\sum_{j} \xi \widehat{B_{j}^{i}} s_{j}^{0} \sigma_{j}\right)^{2}\right)+\sum_{i} \sum_{j}\left(1-\xi^{2}\right)\left(\widehat{B_{j}^{i}} s_{j}^{0} \sigma_{j}\right)^{2}\right]
\end{aligned}
$$

és $Y$ egy standard normális valószínúségi változó.

A bázeli szabályozás, összhangban a nemfizetési kockázat módszertanával egy éves periódus alatt történô veszteségekre határozza meg a tôkeszükségletet, így 
a fenti képletet át kell skáláznunk egy $\frac{1}{\sqrt{H}}$ faktorral. Továbbá az új CVA tôkeszabályozás igyekszik összehangolni a követelményeket az új kereskedési könyv szabályozási keretrendszerrel, így VaR helyett ES kockázati mértéket használ $\alpha=$ $=97.5 \%$ szignifikancia szint mellett.

Megmutatható, hogy egy $X \sim N(\mu, \sigma)$ normális eloszlású valószínúségi változó ES mértéke az alábbiak szerint számolható:

$$
E S_{\alpha}(X)=\mu-\frac{\phi\left(\Phi^{-1}(\alpha)\right)}{1-\alpha} \sigma .
$$

Amiből az következik, hogy

$$
E S_{0.975}(\beta Y)=\frac{\phi\left(\Phi^{-1}(0.975)\right)}{0.025} \beta=2.34 \beta .
$$

Így definiálhatjuk az elsôrendú közelítéssel kapott, 97.5\% szignifikancia szint melletti CVA tôkeszükségletet:

$$
\begin{aligned}
\widehat{C V A}^{\text {toke }}= & 2.34\left[\rho^{2}\left(\sum_{i}\left(A_{i} s_{i}^{0} \sigma_{i}-\sum_{j} \xi \widehat{B_{j}^{i}} s_{j}^{0} \sigma_{j}\right)\right)^{2}\right. \\
& \left.+\left(1-\rho^{2}\right) \sum_{i}\left(\left(A_{i} s_{i}^{0} \sigma_{i}-\sum_{j} \xi \widehat{B}_{j}^{i} s_{j}^{0} \sigma_{j}\right)^{2}\right)+\sum_{i} \sum_{j}\left(1-\xi^{2}\right)\left(\widehat{B_{j}^{i}} s_{j}^{0} \sigma_{j}\right)^{2}\right]^{\frac{1}{2}} .
\end{aligned}
$$

Az így kapott formula hasonló az előző fejezetben közölt, szabályozói tókét meghatározó formula $K_{\text {spread }}$ komponensével, azonban láthatjuk, hogy azzal nem teljes mértékben egyezik meg. Az eltérések főképpen a szabályozói standardizálásból, és a bázeli formula konzervativizmusából adódnak.

A standardizálás legszembetûnóbben a korrelációs és a volatilitás paramétereket érinti. A $\rho$ paraméter a bázeli formulában 0.5 értéket vesz fel, míg a hedgekhez tartozó hitelfelárak a referencia név felárával való korrelációja $(\xi)$ a 4.1 . táblázat alapján változik. Ahogy arra már Pykhtin (2012) is rámutatott, a standardizált formula esetében a kezdeti felár és a korrelációs paraméter együtt egy standard szabályozói súlyra cserélődnek. A standardizált súlyok az új alap CVA módszerben megváltoztak és a 2.34-es szorzót is magukban foglalják. Új értékük a 4.2 . táblázatban láthatóak.

A fenti egyenletben szereplő CVA érzékenységet a szabályozás az alábbi egyenlőtlenséggel becsüli felül:

$$
\begin{aligned}
& A_{i}=\sum_{k=0}^{N} E E_{i}^{*}\left(t_{k}^{i}\right) \Delta t_{k}^{i} e^{-s_{i} t_{k}^{i} / L G D_{i}}\left(1-s_{i} t_{k}^{i} / L G D_{i}\right) \leq \sum_{k=0}^{N} E E_{i}^{*}\left(t_{k}^{i}\right) \Delta t_{k} \\
= & M_{i} 1 / H \sum_{t_{k}<H} E E_{i}^{*}\left(t_{k}\right) \Delta t_{k}^{i} \leq M_{i} 1 / H \sum_{t_{k}<H} E E_{i}\left(t_{k}\right) \Delta t_{k}^{i}=M_{i} E P E_{i}=M_{i} \frac{E A D_{i}}{\alpha} .
\end{aligned}
$$


4.2. táblázat. Kockázati súlyok

\begin{tabular}{lcc} 
Szektor & $\begin{array}{c}\text { Befektetésre } \\
\text { ajánlott (IG) }\end{array}$ & $\begin{array}{c}\text { Befektetésre } \\
\text { nem ajánlott (NIG) }\end{array}$ \\
\hline Államok, Központi bankok, Multilaterális fejlesztési bankok & $8.8 \%$ & $20.4 \%$ \\
Pénzügyi ideértve kormányzat által garantált pénzügyi & $10.2 \%$ & $17.3 \%$ \\
Alapanyagok, Energia, Ipar, Mezőgazdaság, Gyártás, Bányászat. & $7.1 \%$ & $13.0 \%$ \\
$\begin{array}{l}\text { Fogyasztási cikkek és szolgáltatások, szállítás } \\
\text { és tárolás, adminisztratív és ügyfélszolgálati tevékenységek }\end{array}$ & $6.1 \%$ & $14.4 \%$ \\
$\begin{array}{l}\text { Technológia és távközlés } \\
\text { Egészségügy, önkormányzat, kormányzat által garantált } \\
\text { nem-pénzügyi, oktatás, közszolgálat, múszaki tevékenységek }\end{array}$ & $5.1 \%$ & $13.0 \%$ \\
Indexek & $4.1 \%$ & $8.7 \%$
\end{tabular}

Az elsô egyenlőtlenségnél elhagytam az $\left(1-s_{i} t_{k}^{i} / L G D_{i}\right)$ egynél kisebb tényezôt. A következố egyenletet úgy kaptam, hogy az effektív lejárat képletében megfeleltettem egymásnak a valódi és az effektív kitettség profilt. Végül a diszkontált profilt a valódival becslem felül és Pykhtin (2012) munkáját követve eltekintek a kockázatsemleges és a valódi mérték alatt számolt várható kitettség profil különbségétől.

A másik oldalon, Pykhtin (2012) megadja a hedge közelítésének módját is. Ha feltételezzük, hogy $s_{j}=s_{j}^{\text {contr }}$ akkor:

$$
\begin{aligned}
\widehat{B_{j}^{i}} & =B_{j}^{i} \sum_{k=0}^{N^{\prime}} D\left(0, t_{k}^{j}\right) \Delta t_{k}^{j} e^{-s_{j} t_{k}^{j} / L G D_{j}} \\
& \leq \widehat{T}_{j} B_{j}^{i} \frac{1}{\widehat{T}_{j}} \sum_{k=0}^{N^{\prime}} D\left(0, t_{k}^{j}\right) \Delta t_{k}^{j} \approx \widehat{T}_{j} B_{j}^{i} \frac{1}{\widehat{T}_{j}} \int_{0}^{\widehat{T}_{j}} D(0, t) d t .
\end{aligned}
$$

Tehát az utolsó egyenletben megjelenik a lejárat és a diszkontált névérték szorzata, amit még a bázeli formula tovább egyszerúsít, mivel egy $5 \%$ szinten konstans hozamgörbét tételez fel. Ezzel az átalakítással eljutottunk a CVA tóketartalék szabályozói formulájához.

\subsection{Numerikus eredmények}

Ebben a fejezetben numerikus példákon keresztül vizsgálom tovább az új módszert. Összehasonlítom a standard és az alap CVA formulák eredményét különböző feltételek mellett. Hasonlóan rámutatok az elméleti modell és a szabályozói formula közelítések által okozott eltéréseire.

Először a $\rho$ paraméter hatását vizsgáltam egy fedezetlen portfólión. A példában 100 partnert tételeztem fel, miközben Pykhtin (2012) munkáját követve mindegyikhez egységnyi szinten konstans kitettség profilt rendeltem. Az egyes ügyletek lejáratát az egy és öt év közötti intervallumból egyenletes eloszlással választottam. A célom az volt, hogy összehasonlítsam az alap CVA módszer mögött 
levezetett egyenlet (4.34 által adott tókeszükségletet és a szabályozói formulából kapott értéket.

A számítást három különböző minőségú portfólión végeztem el. Mindhárom esetben a $[-1,1]$ intervallumon futtattam a $\rho$ paramétert. Minden számoláskor 100000 szimulációt végeztem, ahol elôször a partnerek hitelminósítését, valamint szektorbeosztását határoztam meg, majd a hitelfelár volatilitásukat. A szektorokat a 4.2 táblázat 2. és 6 . sora közötti értékek közül, míg a volatilitás paramétereket Pykhtin (2012) munkájához hasonlóan a [0.2,0.4] intervallumból egyenletes eloszlással választottam. A három eset a hitelminősítések tekintetében különbözik. Az elsố esetben $[A A, A, B B B, B B, B, C C C]$ partnereket szimuláltam. A második esettel egy jó minőségú portfóliót illusztráltam, így $[A A, A, B B B, B B]$ minôsítésû partnereket tételeztem fel. Az utolsó esetben a $[B B B, B B, B, C C C]$ értékekből választva egy rosszabb minôségú portfóliót szemléltettem. A kezdeti hitelfelár szintek ezek a paraméterek alapján már adódnak, hiszen a 4.34 és a 4.10. egyenletek alapján $R W_{i}=2.34 s_{i}^{0} \sigma_{i}$. Az így kapott portfóliót futtattam mindkét módszertan mellett.

4.1. ábra. A korreláció hatása egy átlagos portfólió esetén
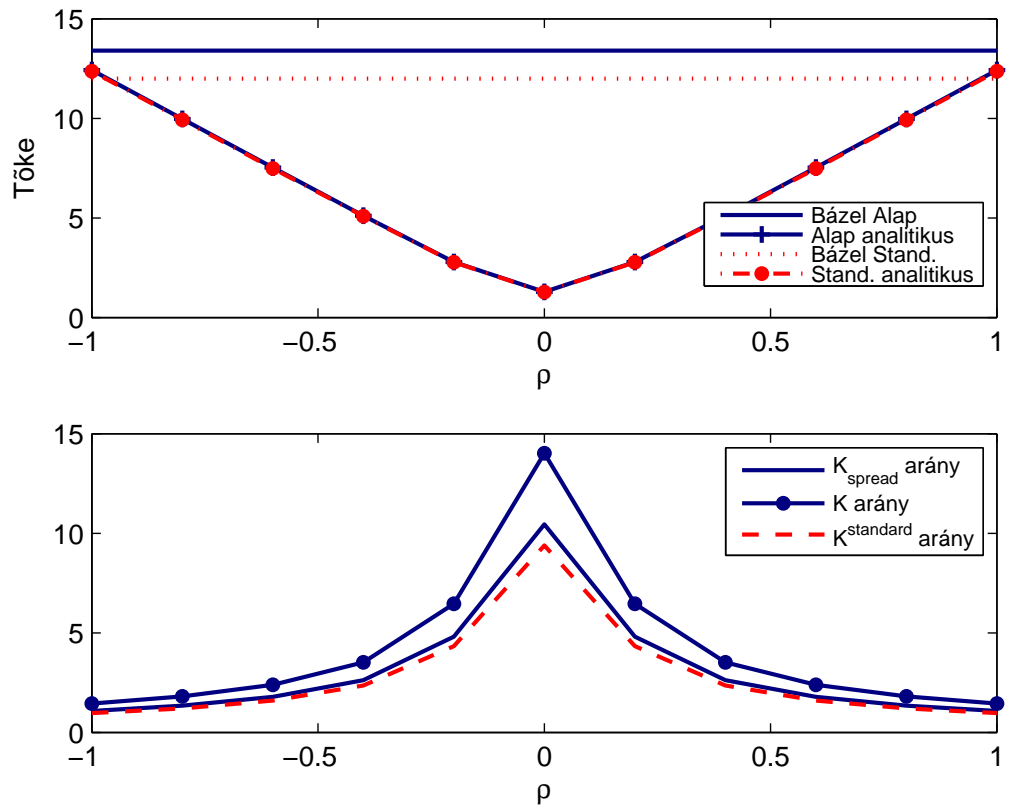
4.2. ábra. A korreláció hatása jó minőségủ portfólió esetén
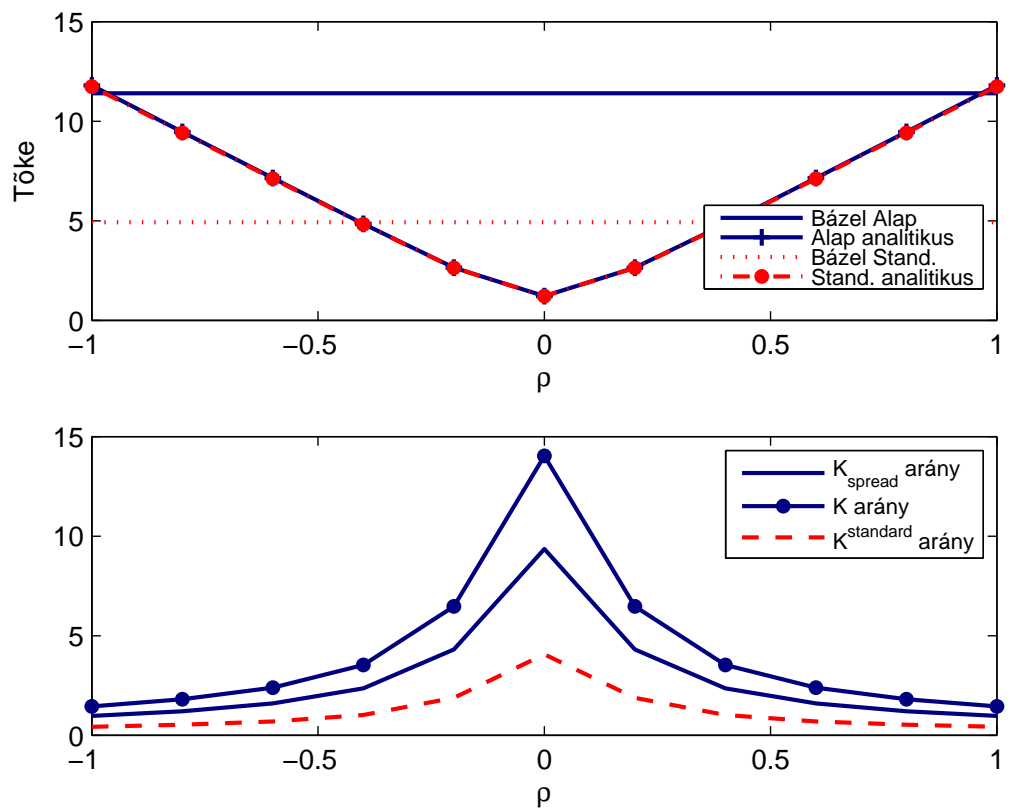

4.3. ábra. A korreláció hatása rossz minôségú portfólió esetén
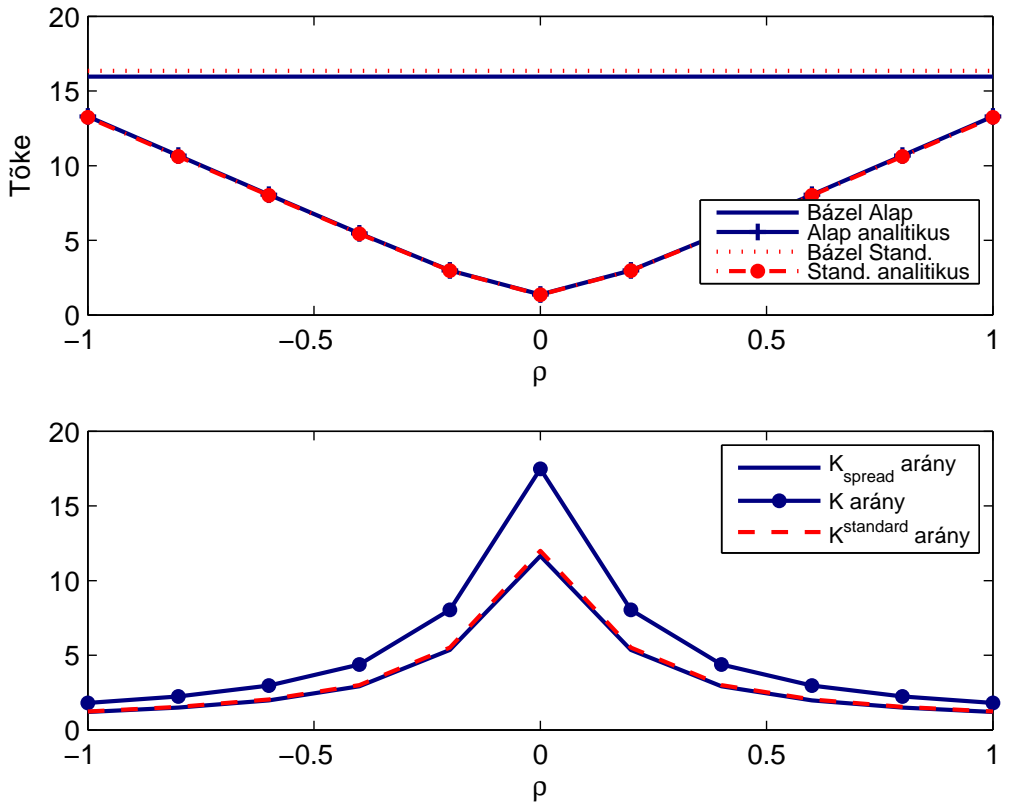

Az eredményeket a 4.1, a 4.2. és a 4.3 ábrákon szemléltetem. Minden ábra két részből áll. A felsô részen $\rho$ különböző értékei mellett, az új alap és a Bázel 3 szabályozás standardizált módszereinek analitikus közelítésével számított tőkeszükséglet értékét adtam meg. Ezekhez az „Alap analitikus” és a „Stand. analitikus" neveket rendeltem a jelmagyarázatban. Ezzel párhuzamosan kiszámoltam a szabályozói formulák által előírt tóketartalék nagyságát is. Az így kapott ered- 
ményeket a „Bázel Alap” és a „Bázel Stand.” egyenes vonalak reprezentálják ${ }^{11}$ A szabályozói tókeszükséglet nem érzékeny a $\rho$ változására, hiszen a bázeli formulában a $\rho=0.5$ választással éltek a BCBS döntéshozói.

A tóketartalékok szintjei mellett érdemes azok a modellhez képesti konzervativitását is elemezni, ezért megvizsgáltam a szabályozói formula és a modell által adott szükséges tôkeszintek hányadosait. Az így kapott eredményeket az ábra alsó felében mutatom be. A „K $K_{\text {spread }}$ arány” mutatja a hitelfelár mozgásából adódó kockázatra számolt szabályozói és analitikus közelítés arányát. A „K arány” számítása a „K$K_{\text {spread }}$ arány”-hoz hasonló, de figyelembe vettem az alap CVA módszer teljes tókeszükségletét, amit a 4.9. egyenlet alapján számoltam. Végül a „K$K^{\text {standard }}$ arány" jelenti a jelenlegi módszer alapján vett hányadost.

Mindhárom portfólió esetében a valódi tôkeszükséglet minimális és a szabályozói formula fölülbecslése maximális a $\rho=0$ esetben. Ilyen helyzetben ugyanis a portfóliót semmilyen közös faktor nem vezérli, így jellemzően az eloszlás farkában a portfólió szintú veszteségek kisebbek lesznek, hiszen az egyes partnerekhez rendelt veszteségek gyakran nyereségekkel lesznek kompenzálva és azok kioltják egymást. Az ábrákon az is jól kivehető, hogy a két módszer analitikus közelítésével kapott eredmények a fedezetlen portfóliókra szinte egybeesnek. Ez a korábbi levezetés tükrében nem meglepő, hiszen láthattuk, hogy az új formula fóképp a fedezeti ügyletek kezelésében tér el elődjétől. A szabályozói egyenlet legjobban a vizsgált intervallum szélein becsül alul. Ilyen esetben ugyanis távol kerülünk a szabályozói $\rho=0.5$ paramétertól, és a formula jellemzóen már nem képes az abszolút értékben szélsőségesen nagy korrelációval járó magasabb veszteségeket kezelni.

Az átlagos portfólió esetében a hitelfelár mozgásából adódó veszteség elleni szabályozói tókeszükséglet szigorít a Bázel 3 követelményein, mivel már az „Alap tôkeszükséglet” is magasabb értéket vesz fel a korábbinál. Figyelembe véve a profil változásának a kockázatát is, a tényleges tôkekövetelmény még magasabb lesz. A „K$K^{\text {standard }}$ arány” és a „K arány” összehasonlításával óvatosnak kell lennünk. A „,K $K^{\text {standard }}$ arány” tisztán a hitelfelár változásból adódó veszteségeket mutatja, míg a „ $K$ arány” esetén helyesebb lenne a nevezôben a profil változásának hatását is szerepeltetni. Másrészt azonban a szabályozói formula sem a profil változásának kockázatát számszerúsíti, hanem a hitelfelár egyenletét használja fel újra. Így egy új szemléletmóddal az alap CVA tókeszükségletet a jelen helyzetben úgy is tekinthetjük, mintha a hitelfelár mozgását másfélszeresen tókésítené. Ezért a „K$K^{\text {standard }}$ arány" és a „K arány” összehasonlításnak egy ilyen alternatív megközelítés mellett van értelme: A 4.1. ábrán láthatjuk, hogy az új módszer jelentôsen

${ }^{11}$ A „Bázel Alap” csak a hitelfelár kockázat elleni tókésítés, azaz a $K_{\text {spread }}$ tag. A teljes tôkenagyság jelen példában ennek pontosan a másfélszerese. 
4.3. táblázat. Kockázati súlyok az iparági felmérés keretében

\begin{tabular}{|c|c|c|c|c|}
\hline & \multicolumn{2}{|c|}{ 1. Opció } & \multicolumn{2}{|c|}{ 2. Opció } \\
\hline Szektor & $\begin{array}{l}\text { Befektetésre } \\
\text { ajánlott } \\
\text { (IG) }\end{array}$ & $\begin{array}{l}\text { Befektetésre } \\
\text { nem ajánlott } \\
\text { (NIG) }\end{array}$ & $\begin{array}{l}\text { Befektetésre } \\
\text { ajánlott } \\
\text { (IG) }\end{array}$ & $\begin{array}{l}\text { Befektetésre } \\
\text { nem ajánlott } \\
\text { (NIG) }\end{array}$ \\
\hline Államok, Központi bankok, & & & & \\
\hline Multilaterális fejlesztési bankok & $0.5 \%$ & $3.0 \%$ & $0.9 \%$ & $3.7 \%$ \\
\hline $\begin{array}{l}\text { Önkormányzat, kormányzat által garantált } \\
\text { nem-pénzügyi, oktatás és közszolgálat }\end{array}$ & $1.0 \%$ & $4.0 \%$ & $1.2 \%$ & $4.0 \%$ \\
\hline Pénzügyi ideértve & & & & \\
\hline kormányzat által garantált pénzügyi & $5.0 \%$ & $12.0 \%$ & $6.1 \%$ & $12.0 \%$ \\
\hline Alapanyagok, Energia, Ipar, & & & & \\
\hline Mezőgazdaság, Gyártás, Bányászat. & $3.0 \%$ & $7.0 \%$ & $3.7 \%$ & $7.0 \%$ \\
\hline $\begin{array}{l}\text { Fogyasztási cikkek és szolgáltatások, } \\
\text { szállítás és tárolás, adminisztratív } \\
\text { és ügyfélszolgálati tevékenységek }\end{array}$ & $3.0 \%$ & $8.5 \%$ & $3.7 \%$ & $8.5 \%$ \\
\hline Technológia és távközlés & $2.0 \%$ & $5.5 \%$ & $2.4 \%$ & $5.5 \%$ \\
\hline Egészségügy, múszaki tevékenységek & $1.5 \%$ & $5.5 \%$ & $1.8 \%$ & $5.0 \%$ \\
\hline
\end{tabular}

magasabb arányt rendel a portfólióhoz tetszôleges $\rho$ esetén, ami azt jelenti, hogy a hitelfelár mozgását sokkal szigorúbban tókésíti.

Az eredmények részben hasonlóak, ha megváltoztatjuk a partnerek hitelminósítését, de érdemes rámutatni két fontos eltérésre. Egyrészt a jobb portfóliót 4.2 . ábra) tekintve az új módszer sokkal szigorúbb, mint az átlagos portfólió esetében. Ilyenkor ugyanis már a „Bázel Alap” szint is többszöröse a „Bázel Stand.” tókeszükségletnek. Ugyan láthatjuk, hogy az elôző formula az intervallum nagy részén alulbecsült, de ekkora mértékú szigorításra nehéz magyarázatot találni. Másrészt a rossz minőségú portfólió (4.3. ábra) esetén az abszolút tókeszükséglet és az arányszámok magasabbak, de a korábbi megfigyeléseink továbbra is igazak. Magasabb arányszám jellemzôen konzervatívabb standardizálást jelent, hiszen ilyen esetben a szabályozói formula jobban eltér a modell által előjelzett értéktól.

A Bázeli Bankfelügyeleti Bizottság 2016. februárjában egy iparág szintú gyakorlat keretein belül egy kissé módosított szabályozást adott ki. A módosítás nem érintette az alap CVA módszertanát, viszont a paramétereit újrakalibrálták. Így a kockázati súlyok is megváltoztak. A QIS instrukciójában a Bázeli Bankfelügyeleti Bizottság arra kérte a résztvevô bankokat, hogy végezzenek teszteket a saját portfóliójukon két különböző paraméter halmazt is felhasználva. Az új kockázati súlyok a 4.3 . táblázatban láthatóak.

A fentebb ismertetett elemzést az új kockázati súlyokkal is elvégezve valamelyest eltérô képet kapunk. A 4.4-4.6. ábrák felső részén a legszembetúnőbb változás, hogy a szabályozói formula és az analitikus közelítés metszéspontjai alacsonyabbra kerültek. Ez azt mutatná, hogy a szabályozói formula kevésbé szélsőséges korreláció mellett is képes alulbecsülni a modell szerint elvárt tókeszükségletet, 
azonban a másfélszeres szorzó alkalmazása után ez a lehetôség eltûnik. Továbbá megállapíthatjuk, hogy a tốkeszükséglet abszolút szintje mindhárom típusú portfólió esetében csökkent.

Fontos megjegyezni, hogy az előző ábrákkal való összehasonlításnál figyelembe kell vennünk, hogy idóközben a portfólió is megváltozott. Ugyan a hitelminôsítés és a hitelfelár volatilitás ugyanaz, mint korábban, de a hitelfelárak kiinduló szintjei az $R W_{i}=2.34 s_{i}^{0} \sigma_{i}$ összefüggés miatt megváltoztak, hiszen új kockázati súlyokat használok. A bázeli formula nem használja a hitelfelárakat, így bázeli szemüvegen keresztül a két portfólió megegyezik. Ezért az abszolút tókeszükséglet nagyságának összehasonlítását megtehetjük, de a modell által adott eredmények eltéréseikor figyelembe kell vennünk a lehetséges portfólió hatásokat is. Ha az ábrák alsó részére tekintünk, akkor láthatjuk, hogy a „ $K_{\text {spread }}$ arány” vagy a „K arány" már nem minden esetben a legmagasabb.

4.4. ábra. A korreláció hatása egy átlagos portfólió esetén - QIS súlyokkal
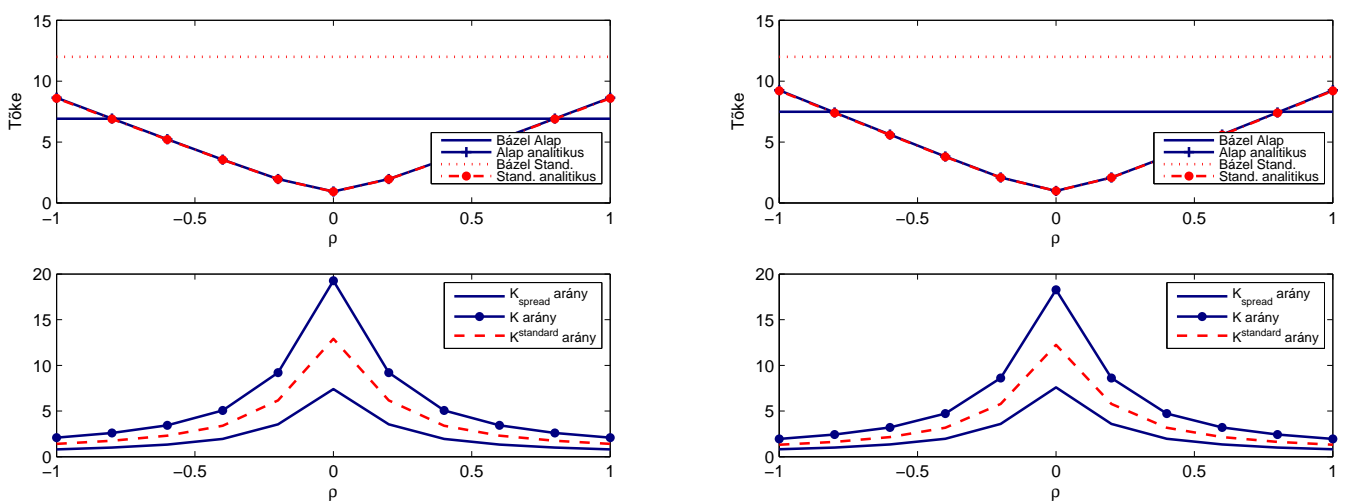

4.5. ábra. A korreláció hatása jó minôségú portfólió esetén - QIS súlyokkal
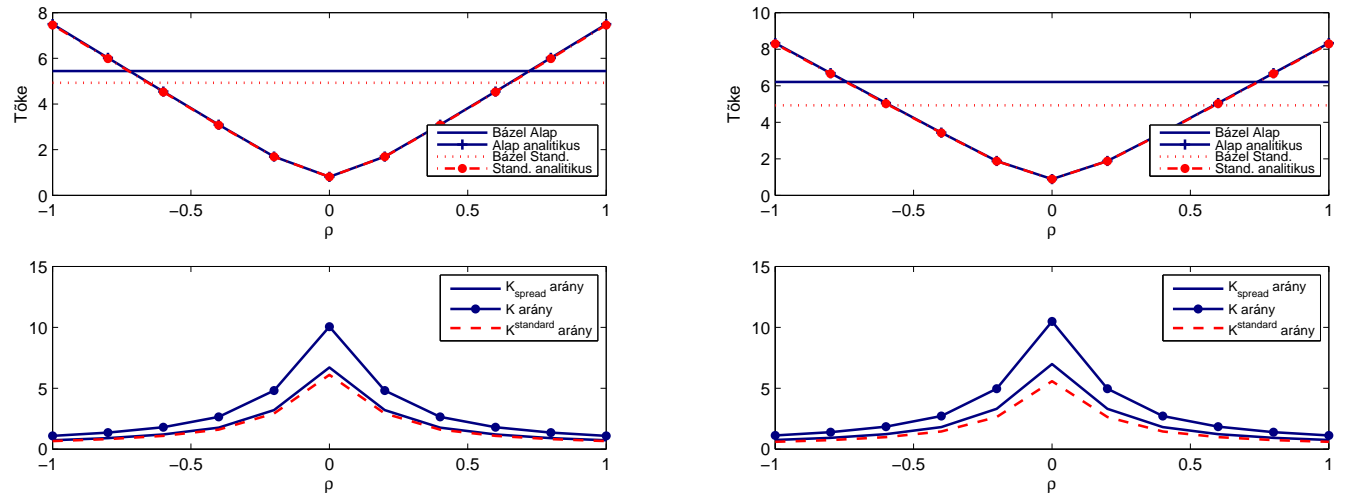
4.6. ábra. A korreláció hatása rossz minőségú portfólió esetén - QIS súlyokkal
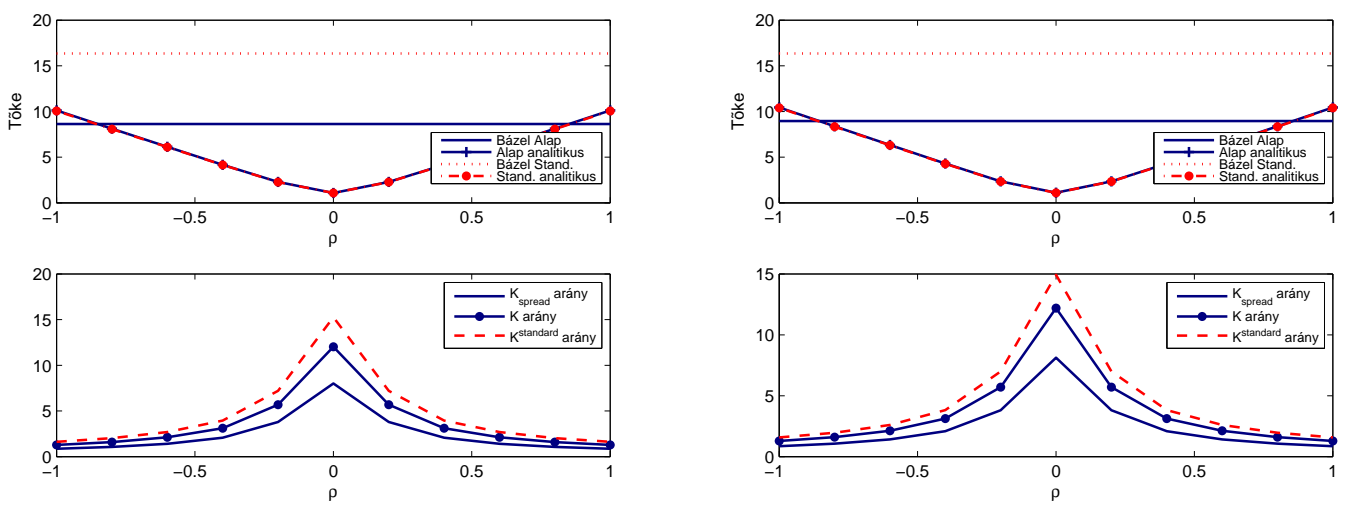

A fedezés hatásának teszteléséhez egy egyetlen partnerból álló portfóliót tételeztem fel, ahol minden egyes számításhoz 100000 szimulációt futtattam. A cél a tökéletes fedezéshez szükséges portfólió megtalálása, miközben megvizsgáltam, hogy egy ilyen portfólió hitelfelárának mozgása mekkora tókeszükséglettel jár. Így azt feltételeztem, hogy a hitelértékelési kiigazítást számoló fél a partnerére vásárolt fedezeti ügyletet, azaz mind az analitikus közelítésben mind pedig a szabályozói formulában a $\xi=1$ érték használható. Mivel a standardizált kockázati súlyok, a hitelfelár kiinduló értéke és annak volatilitása összekötik az analitikus közelítést és a bázeli formulát, ezért ezek értékeit nem lehet egymástól függetlenül megválasztani. A jelen példában két hitelminősítést (AA (IG), B (NIG)) vizsgálok alacsony (20\%) és magas (40\%) hitelfelár volatilitást feltételezve.

Az analitikus közelítés 4.34 képletéból láthatjuk, hogy az $i=j$ és így $\xi=1$ esetekben a hedge tökéletes, ha $A_{i}=\hat{B}_{i}$. Ennek eléréséhez a hedge lejáratát valamint névértékét kell jól beállítani, figyelembe véve az eredeti ügylet lejáratát valamint a diszkontált profil alakját. Hasonló témát vizsgál Berns (2016) is, aki a hatályos standardizált CVA tôkeformula esetén a nulla tókekövetelményú és a tökéletesen fedezett portfólió eltérését elemzi. Berns (2016) alapján a fedezéséhez egy $B=\frac{1}{M} \int_{0}^{M} E E(t) d t$ névértékú hitelmulasztási számviteli CVA ügyletet kell vásárolni, míg a standardizált CVA szabályozás szerint egy nulla tőkekövetelményư portfólióhoz $B=E A D$ névértékú CDS-re van szükség. Ez alapján könnyen adódna, hogy az alap CVA szabályozás szerint $B=E A D / \alpha$ mellett kapnánk nulla tókekövetelményt, feltéve, ha a lejáratokat összeegyeztettük. Míg Berns (2016) közelítése bizonyos esetekben igaz, vegyük észre, hogy számos egyszerúsítése miatt nem ad tökéletes leírást. Berns (2016) munkájában ugyanis figyelmen kívül hagyja a CDS prémium lábának a hitelfelárak mozgásából adódó értékmegváltozását, a hitelértékelési kiigazítást az effektív lejáratig vett integrálként írja fel, és megkülönböztetés nélkül használja a fedezeti ügylet diszkontált és a valódi névér- 
tékét. A korábban felírt modellkeret mellett pontosabb elemzést lehet elvégezni, ezért folytassuk a numerikus eredmények bemutatásával.

A példában a konstans kitettség profil szintjét, az eredeti ügylet lejáratát, és a hedge névértékét is egységnyinek választottam és így a hedge lejárata az egyetlen változó paraméter ${ }^{12}$ Így a tökéletes fedezetet meghatározó lejáratot kerestem, miközben a bázeli tôkeszükségletet is számoltam.

$\mathrm{Az}$ eredményeket a 4.7 és a 4.8 ábrákon szemléltetem, ahol is a lejáratok függvényében mutatom a tôkeszükséglet nagyságát. Első ránézésre a vízszintes tengelymetszetek eltérése a legszembetúnőbb. Láthatjuk, hogy a bázeli formula szempontjából tökéletesen fedezett portfolió, valójában nem kockázatmentes, és hasonlóan a ténylegesen hedgelt portfolió tôkeszükséglete nem nulla. Ez a megfigyelés a jelenleg hatályban lévő standardizált formulára is igaz, ezért az új módszer célja volt, hogy jobban összehangolja a számviteli és a szabályozói hitelértékelési kiigazítást, és javítsa a fedezeti ügyletek felismerését. Az $\alpha$ faktorral történő osztás a 4.12 egyenletben segített ezen, azonban ahogy az ábrán láthatjuk, a tökéletes egyezés továbbra sem áll fenn.

\section{7. ábra. IG Portfólió}
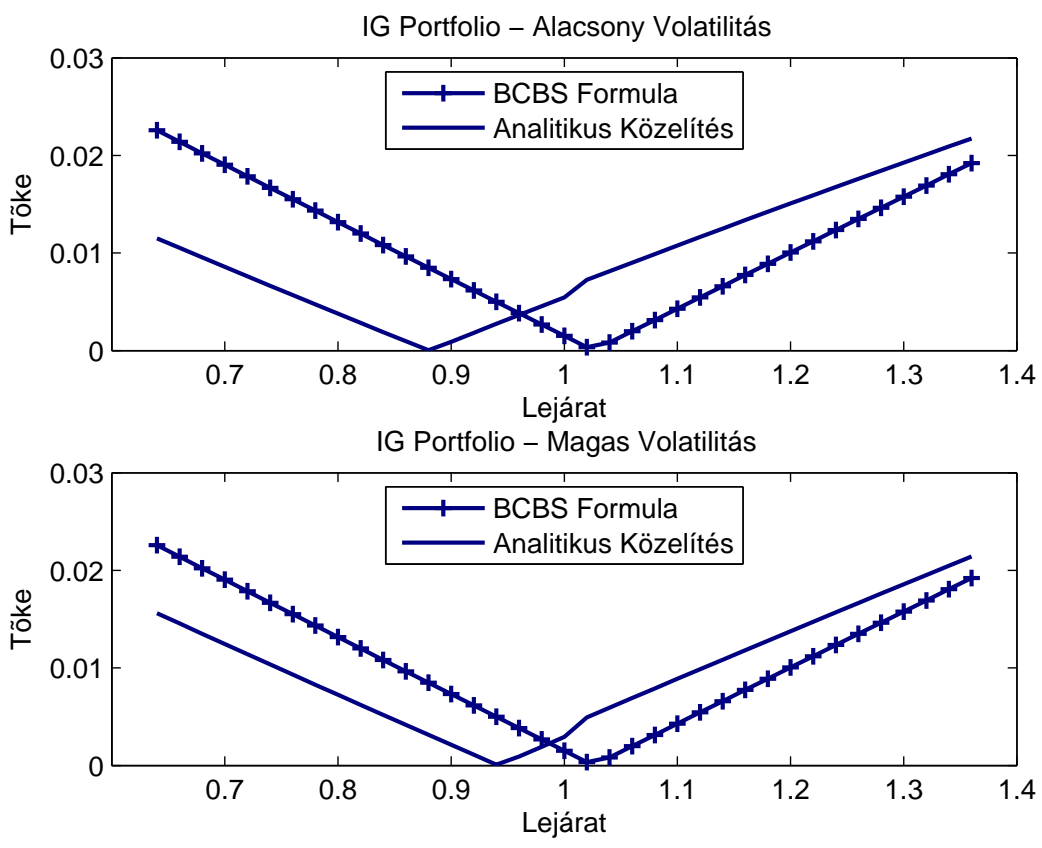

${ }^{12}$ Nem szabad elfelejtenünk, hogy egy fedezési céllal kötött CDS ügylet újabb kitettséget generálhat. Ez megváltoztathatja a portfólió szintû hitelértékelési kiigazítás értékét, így a tökéletesen fedezett CVA nem minden esetben elérhetô. Egységnyi kitettség profil választásával ezt a kapcsolatot figyelmen kívül hagytam a numerikus példában. Ez az egyszerúsítő feltételezés azonban valós piaci helyzetben is elképzelhetô, hiszen ugyanilyen eredményhez jutunk, ha fedezeti ügyleteket klíringházon keresztül kötjük. 


\section{8. ábra. NIG Portfólió}
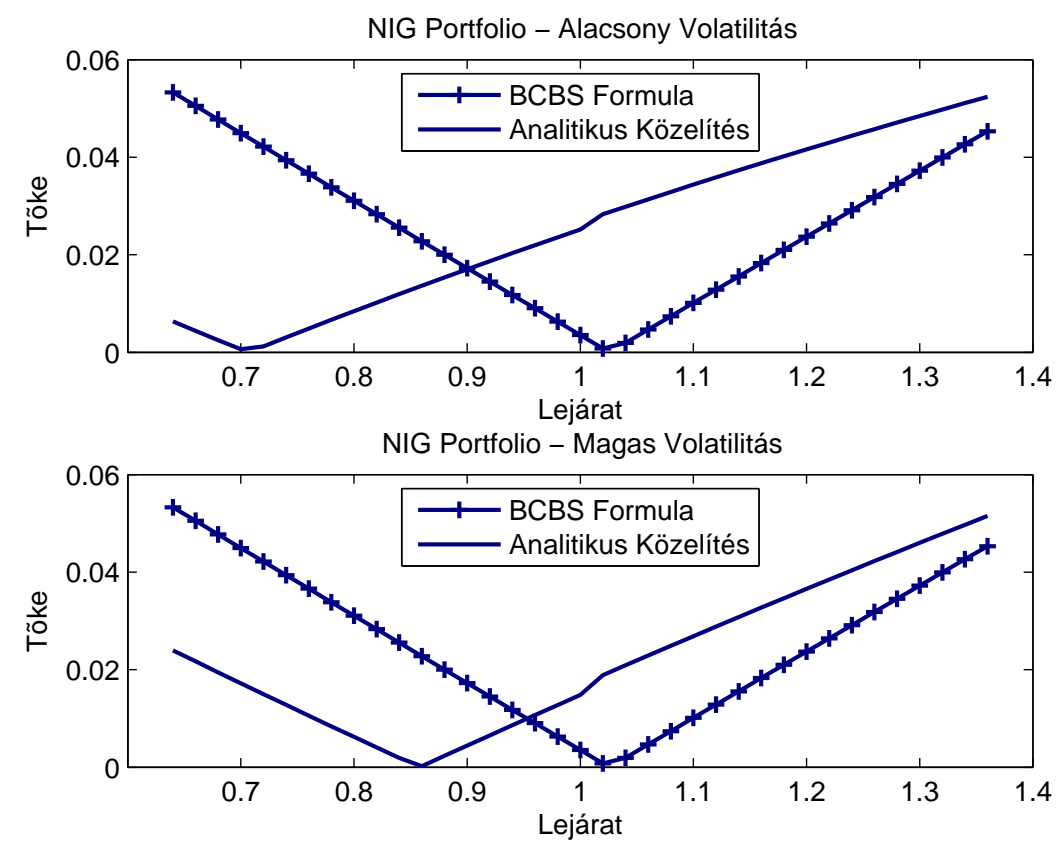

Jellemzően a fedezeti ügylet lejáratának rövidítésével érhetünk el tökéletes fedezetet a 4.34 egyenlet alapján, amit elsôsorban a CDS prémium lábával magyarázhatunk. A hitelfelár változása ugyanis a CDS fix és változó lábára is hatással van. Növekedő felárak esetén a csőd esetén fizetô láb többet ér. Ezzel szemben a csôdig tartó prémium fizetés kevesebbet fog érni, hiszen a túlélés valószínúsége csökken. Így a CDS értéke két okból is változik, így az jobban ellensúlyozza a CVA változását és csökkenti a tökéletes fedezethez szükséges lejáratot. Alacsony hitelfelár volatilitás mellett nagyobb kezdeti felárról indulunk, mivel $R W_{i}=2.34 s_{i} \sigma_{i}$. Így az $s_{i}^{\text {contr }}$ tag szerepe a 4.24 egyenletben is nagyobb lesz, ezért láthatjuk, hogy a kisebb volatilitás mellett a hedge lejárata tovább csökkenthető.

Másrészt a fenti egyszerú portfólió mellett az alap CVA formulát is leegyszerûsíthetjük, hogy megtaláljuk a tökéletes fedezetet. Hiszen amíg

$$
S_{c}=S_{h}^{S N}
$$

azaz

$$
\frac{R W_{b(c)}}{\alpha} M_{n s} E A D_{n s}=R W_{b(c)} M_{h}^{S N} B_{h}^{S N}
$$

teljesül, addig a tôkeszükséglet értéke nulla lesz. Egyszerüsítve a fenti egyenletet, és behelyettesítve az eredeti ügylet effektív lejáratát és a fedezeti ügylet diszkontált névértékét, az alábbi egyenlőség adódik:

$$
E E P E_{n s}=M_{h}^{S N} B^{i} \frac{1}{M^{S N}} \int_{0}^{M^{S N}} D(0, t) d t=B^{i} \int_{0}^{M^{S N}} D(0, t) d t .
$$

A példában egységnyi névértéket és EEPE-t feltételeztem, így adódik, hogy a jellemzốn egységnél kisebb diszkontfaktorokat valamivel egy éven túl kell in- 
tegrálni, hogy teljesüljön a fenti feltétel. Ez látszik a 4.7 és a 4.8 ábrákon is, hiszen minden esetben valamivel egy év feletti lejáratú hedge esetén kapom meg a nulla tőkeszükségletet. Érdekes látni, hogy az ábrázolt szabályozói tókeszükséglet ugyan függ a portfólió hitelminőségétôl, annak minimuma ettől független. Az analitikus közelítés és a szabályozói formula eltérései az érzékenységi paraméterek előzô alfejezet végén megadott átalakításaiból adódnak.

A fentiek alapján láthatjuk, hogy ha nagyon magas volatilitást tételezünk fel, akkor az analitikus közelítés minimuma közelebb kerül a szabályozóihoz. Azonban ebból adódik egy újabb, az ábrákon is jól látható megfigyelés, ami szerint a példához hasonló esetekben a szabályozói formula bizonyos intervallumokon alulbecsülheti a tényleges tókeszükségletet. Láthatjuk, hogy az alulbecslés a szabályozói függvény meredek növekedése miatt csupán egy rövid intervallumon áll fenn, és annak mértéke sem túl jelentôs, azonban ez mégis egy fontos észrevétel, hiszen rámutat a korábban közölt átalakítások melléktermékére.

A tökéletes fedezetre vonatkozó tesztet a QIS súlyok alapján is újrafuttattam. Az eredményeket a 4.9 és a 4.10 ábrákon szemléltetem. Ugyan a tökéletesen fedezett és a zéró tókeszükségletú portfóliók továbbra sem esnek egybe, a tesztportfóliónkon javulást láthatunk mindkét opció mellett. A két portfólió közeledésének az oka az új kockázati súlyok alacsonyabb szintjei. Ilyen feltétel mellett a tesztportfólióhoz alacsonyabb kiinduló hitelfelárat rendelhetünk, ami a korábban leírtak miatt közelebb viszi két a portfóliót.

4.9. ábra. IG Portfolió - 1. opció (balra) és 2. opció (jobbra)
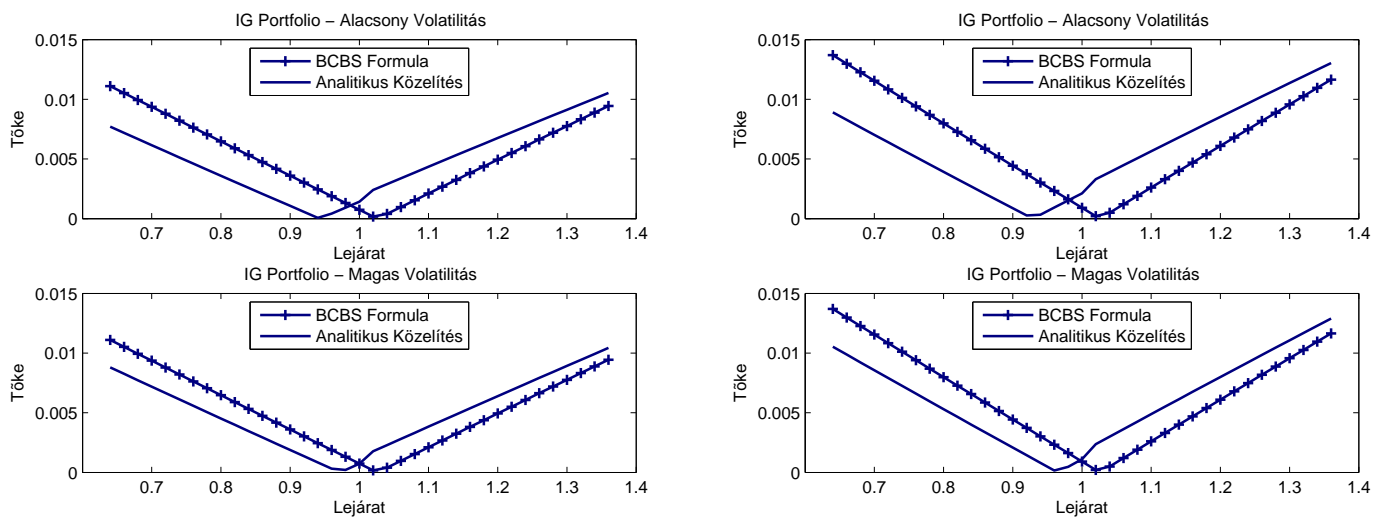
4.10. ábra. NIG Portfolió - 1. opció (balra) és 2. opció (jobbra)
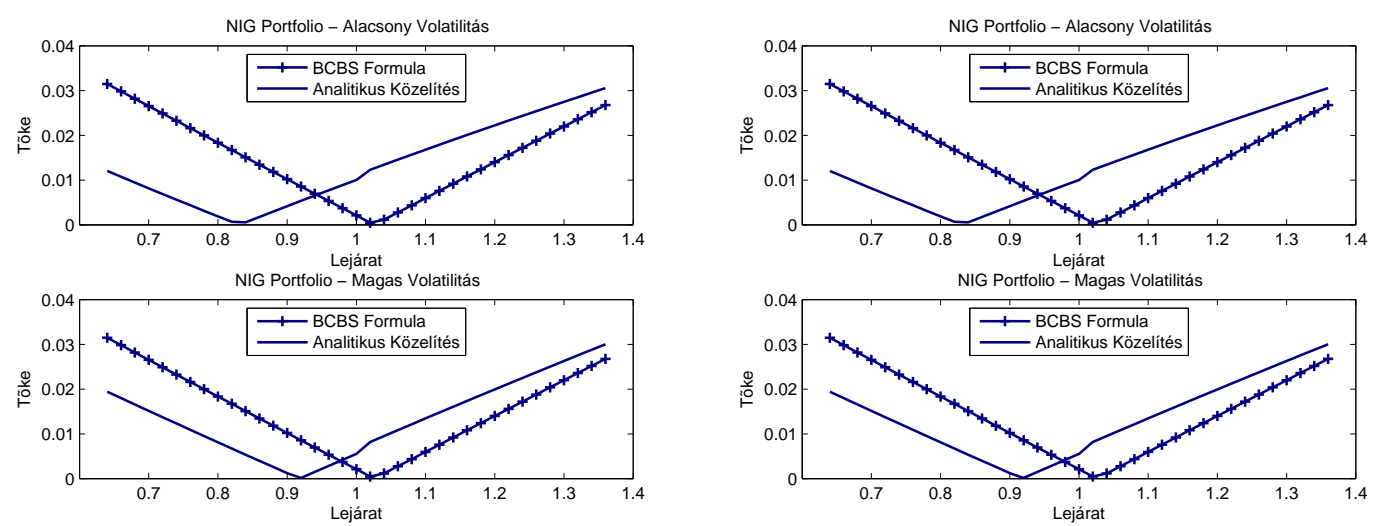

\subsection{A végső szabályozói keret}

A Bázeli Bankfelügyeleti Bizottság végül 2017 decemberében publikálta a CVA tőketartalékolási rendszer hivatalos szabályait (BCBS, 2017). Összhangban a korábbi várakozásokkal, a végső dokumentum az alap és a standard CVA módszert adja meg lehetséges tókeszámítási eljárásként. Az alap CVA módszer kerete lényegében megegyezik az előző fejezetekben bemutatott változattal, és a kockázati súlyok végsố értékei egybeesnek a QIS elsố opciójaként meghatározott súlyokkal. Így az analitikus eredményeim valamint a numerikus elemzés egy része közvetlenül átültethetô a végsô módszerre is. Az alap CVA 2017 decemberi verziója azonban egy fontos ponton változtat a korai változatokon, amely eltérést érdemes bemutatni.

Az eltérést a fejezet elején adott 4.9 . egyenletben találjuk. A végsô szabályozás alapján az alap CVA módszer teljes tôkeszükséglete az alábbi formában áll elő:

$$
K=0.75 K_{\text {spread }}+0.25 K_{\text {spread }}^{\text {nohedge }},
$$

ahol a $K_{\text {spread }}$ tagot már korábban definiáltam, míg $K_{\text {spread }}^{\text {nohedge }}$ megegyezik a $K_{\text {spread }}$ fedezeti ügyletek elhagyásával kapott alakjával, azaz:

$$
K_{\text {spread }}^{\text {nohedge }}=\left[\left(\rho \sum_{c} S_{c}\right)^{2}+\left(1-\rho^{2}\right) \sum_{c} S_{c}^{2}\right]^{\frac{1}{2}}
$$

Ugyan $K_{\text {spread }}^{\text {nohedge }}=2 K_{E E}$, de a $K_{E E}$ jelölés a szabályozásban is elhagyásra került, annak érdekében, hogy ezt a tagot ne lehessen közvetlenül a kitettséghez társítani. A végleges alap CVA módszer szerinti tőkeszükséglet tehát előáll, mint a hitelfelárak mozgásából adódó tôkeszükségletet számszerúsítô szabályozói formula fedezeti ügyleteket figyelembe vevó és azokat figyelmen kívül hagyó alakjainak 
súlyozott átlaga. ${ }^{13}$ Ezáltal a kitettség mozgásából adódó veszteségek miatti tôkeigény $\left(K_{E E}\right)$ kikerült a szabályozásból. Ennek ellensúlyozása érdekében a fedezeti ügyletek beszámíthatósága csökkent. Ez a változtatás egy vitatott megközelítést cserél le, de a kitettség profilok mozgásának számszerűsítése helyett a Bizottság egy másik, szintén egyszerúsítésen alapuló módszert vezetett be. Feltételezhetjük azonban, hogy a Bázeli Bankfelügyeleti Bizottság a fenti alakra kalibrált tôkeszükségletet az iparági felmérések tükrében találta megfelelőnek.

A korábbi alfejezetekben ismertetett analitikus eredmények ugyanúgy igazak a fenti formula mellett is. Továbbá a fedezetlen portfóliókra bemutatott numerikus eredmények is helytállóak, azzal a kiegészítéssel, hogy a 4.4 4.6. ábrákon a $K_{\text {spread }}$ arány mutatja a végső arányokat. Ezek alapján levonhatjuk azt a következtetést, hogy az eredeti javaslat jelentôs felülbecslését végül a Bázeli Bankfelügyeleti Bizottság is túl magasnak találta, és ennek megfelelően igazította újra a kockázati súlyokat és a fố egyenletet. Végül vegyük észre, hogy a fedezet kérdése nem oldódott meg teljesen. Az új javaslatban már nem választható szét a hitelfelárak és a kitettség mozgásából adódó veszteségekre tartalékolt tôke. Így nem is tesztelhetjük, hogy a formula alulbecsli-e a hitelfelárak mozgása miatti tókeszükségletet. A két tag összegét vizsgálva a szabályozói formula által generált tőkeszükséglet nem fogja elérni az analitikus közelítés minimum szintjét, hiszen egy hatékonyan fedezett portfolió tőkeszükségletében is meg fog jelenni a fedezet elhagyásával számolt pozitív tôkeigény. Ez egyrészt orvosolhatja az előzőekben kifogásolt szabályozói alulbecslés problémáját, viszont ebben az esetben figyelmen kívül hagyjuk a kitettség mozgásából adódó veszteségeket. Másrészt azonban az analitikus formula és a szabályozói formula minimum helyei továbbra sem fognak egybeesni, azaz a bankoknak továbbra is két cél szerint kell fedezni a portfóliójukat.

\section{5. Összefoglalás}

A bankok és a tóketartalékolás szabályozása az elmúlt évek egyik legfontosabb és legtöbbet elemzett pénzügyi témájává nôtte ki magát. A gazdasági világválság után bevezetett új keretrendszer egy új időszak kezdetét jelentette a bankrendszernek. A szabályozás mértéke és formája azonban folyamatos revízió alatt áll, aminek jó példája a hitelértékelési kiigazítás mozgásából adódó veszteségek elleni tóketartalékolás.

Mivel az egyes új szabályozási javaslatok bankok ezreit is érinthetik, ezért érdemes azokat minél alaposabban elemezni. Ugyan a tényleges hatás elemzését a

${ }^{13}$ A végsố javaslatban az alap CVA módszer két verziója is bevezetésre kerül. Az elôzô állítás a teljes verzió esetében igaz. A másik, úgynevezett redukált változatban a fedezet egyáltalán nem beszámítható, így ebben az esetben $K=K_{\text {spread }}^{\text {nohedge }}$. 
bankok aktuális portfólióján kell elvégezni, mégis célszerú mindig elméleti szempontból is megvizsgálni az új javaslatokat. Azok alapos megértése és tulajdonságainak elemzése elengedhetetlen a szabályozás javítása érdekében. Jelen fejezet a dolgozat témájához igazítva, a hitelértékelési kiigazítás témakörére szorítkozva ehhez a feladathoz történô hozzájárulást túzte ki célul. A szabályozói CVA valamelyest különálló fogalom, de mégis erôsen támaszkodik a korábban vizsgált területekre.

Bázeli Bankfelügyeleti Bizottság 2015 júliusában kiadott javaslata egy új CVA tôketartalékolási rendszert ajánl. Jelen fejezetben az új hitelértékelési kiigazítás szabályozásban leírt alap CVA módszert vizsgáltam meg. Elsóként megmutattam a bázeli formula mögött meghúzódó matematikai modellt és az attól vett szabályozói eltéréseket. Levezetésem alapján látható, hogy az új szabályozói formula az egyes partnerekhez rendelt hitelértékelési kiigazításból és a hozzájuk tartozó fedezeti ügyletekból álló portfólió Expected Shortfall alapú kockázati mértéke. A modell dinamikáját a hitelfelárak változása adja, amely hátterében egy speciális normális faktormodell áll. A levezetés magában foglalja a közvetlenül nem a partnerre vonatkozó, úgynevezett proxy hedgeket is.

Az új formula néhány tulajdonságát és a jelenleg hatályos változatával vett összehasonlítását numerikus példákon keresztül is illusztráltam. Példám során egy hipotetikus portfóliót fedezettel és anélkül teszteltem. Rámutattam, hogy az eredetileg javasolt új kockázati súlyok nehezen indokolható magas tôketartalékolást eredményeznek, miközben a módosított és a végleges javaslatban már bizonyos szintû enyhítést láthatunk. A korreláció hatásának elemzésénél láthattuk, hogy a szabályozói formula felülbecslése a $\rho=0$ esetben, a közös faktor hiánya miatti alacsony veszteségek mellett a legmagasabb. Ez a megfigyelés az eredeti kockázati súlyokkal számolt jobb minôségú portfólió esetében még súlyosabban fennáll.

Numerikus példám második részében megmutattam, hogy a szabályozói és a számviteli hitelértékelési kiigazítás teljes összeegyeztetése továbbra sem történt meg, így a két nézôpont szerint tökéletesen fedezett portfóliók is eltérnek egymástól. Ennek egy melléktermékeként adódott, hogy a szabályozói formula bizonyos intervallumokon alulbecsüli a tényleges tôkeszükségletet. Az elvégzett elemzések mind a bankok kockázatkezelői és mind a szabályozók számára is hasznosak lehetnek. 


\section{5. fejezet}

\section{Összefoglalás}

A dolgozatban a partnerkockázat árazásával, avagy a hitelértékelési kiigazítással foglalkoztam. A terjedelmi korlátokat figyelembe véve, igyekeztem lefedni ennek a szerteágazó témának minél több területét. Eredményeimmel hozzájárultam a hitelértékelési kiigazítás kitettség komponensének fejlett meghatározásához, a csődkorreláció egy alternatív megközelítésmódjához és a CVA tôkeszabályozás fejlődéséhez. Az új észrevételek elősegíthetik a téma elméleti és gyakorlati felhasználásának haladását.

A dolgozat során az elméleti alaposságra törekedtem, és igyekeztem minden esetben az elméleti probléma számszerúsítésével megoldást találni. Ahogy azt azonban a bevezetőben kifejtettem, a téma kutatása során felmerülő problémák tekintélyes része túlmutat a pusztán elméleti jelentőségen, hiszen azok alapvető gyakorlati relevanciával párosulnak. Ezért arra törekedtem, hogy minden esetben a téma gyakorlati felhasználását is érzékeltessem, amely olvashatóbbá és a valósághoz közelebb állóvá teszi a disszertációt.

A sokrétú téma leírását igyekeztem több dimenzió szerint is megbontatni. Egyrészt külön elemeztem a számviteli és a szabályozói hitelértékelési kiigazítást. A számviteli hitelértékelési kiigazítást tovább bontottam annak kitettség és csődesemény komponenseire. Másrészt így logikus sorrendbe helyeztem az egyes fejezeteket, hiszen a számviteli CVA elvezet a szabályozói hitelértékelési kiigazításhoz. Ahogy kifejtettem, a komponensekben bekövetkezô változások a CVA dinamikus jellegét okozzák, aminek egyik eredménye a szabályozói CVA. Így a dolgozat egy alulról felfelé épülő struktúrát kapott. Ezeken túl a bemutatott elemzéseket is különbözô nézôpontokból végeztem el. A felhasználók egy problémájával kezdtem, amiból fokozatosan a szabályozók szemszögéból történő leírásba ment át a dolgozat. Végül az egyes fejezetek a téma alternatív jellemvonásait vizsgálják. Elsóként technikai kérdésekkel foglalkoztam, amelyek a számítás megvalósíthatóságára fókuszáltak. Majd a bevett formalizálást vizsgáltam, méghozzá egy figyelmen kívül hagyott kockázati faktoron keresztül. Ezek után pedig a szabályozás korlátozott- 
ságára hívtam fel a figyelmet. A disszertáció ilyen formában többszörösen bontott váza lehetôséget teremtett arra, hogy a dolgozat elején kitúzött célokat megvalósítsam.

A dolgozat négy fő eredményt tartalmaz, amelyeket külön fejezetekben és alfejezetekben mutattam be. Elsóként egy új eljárást fejlesztettem, amivel a kitettség profilok becslése hatékonyabban végezhetô el, mint a hagyományos Monte Carlo eljárással. Az eljárást egy algoritmus formájában adtam meg, amit numerikus példákon teszteltem. A módszer a többszintű Monte Carlo eljárásra épül, amely lehetôséget teremt a szimulált pontok számának csökkentésére, és így a futási idő szignifikáns redukálására. Második eredményem szintén a hitelértékelési kiigazítás és komponenseinek meghatározásának numerikus módszereihez kapcsolódik. A 2.2. alfejezetben kiegészítettem a legkisebb négyzetes Monte Carlo módszer helyes formáját oly módon, hogy az a fedezet késését is figyelembe vegye. Továbbá a módszert átstrukturáltam, hogy a megnövekedett memória szükségletet csökkentsem. Az eljárást algoritmusok formájában adtam meg külön korai lehívhatósággal nem rendelkezô és azzal kiegészített termékekre. Numerikus példákon rámutattam, hogy az átstrukturált eljárás memória felhasználása szignifikánsan csökken, ugyanakkor a futási idő növekedni fog. A dolgozatban ismertetett harmadik eredmény egy új modellkeret építése és annak elemzése volt, amely modellel a hitelminôsítôk bejelentéseit követô fertőzô hatások számszerúsítése végezhetô el. A modellben az intenzitás folyamat skálázásával építettem be az empirikus tanulmányok által már leírt hatást, miszerint a vállalatok hitelminôsítésében bekövetkező változások befolyásolják társaik túlélését. A modell megoldására a teljes hazard módszer kiterjesztésével építettem egy eljárást, amellyel már numerikus példákon elemezhettem a fertôzố hatások hitelértékelési kiigazításra gyakorolt hatásait. A számpéldák rámutattak, hogy a kétoldalú hitelértékelési kiigazítás sokkal érzékenyebben reagál a fertőző hatásokra, mint az egyoldalú CVA. Továbbá, hogy olyan iparágakban, ahol a hitelminôsítések erôsen koncentrálódnak, a fertôzô hatások szignifikánsan megváltoztathatják a kétoldalú hitelértékelési kiigazítás értékét. Végül negyedik eredményem az új alap CVA szabályozói módszer mögött meghúzódó analitikus modellkeret levezetése és annak elemzése. A 4. fejezetben a tôkeszükséglet levezetésekor megadtam a modellhez kapcsoló, valamint a szabályozók által használt standardizálási feltételeket is. Így összehasonlíthattam a modell által generált tôkeszükségletet és a szabályozói formula elvárását. Végigkövetve a szabályozás fejlődését rámutattam, hogy a javaslatok egy része nehezen indokolható konzervativitást vezetett be, valamint hogy a fedezet kérdése nincs megfelelóen kezelve.

Új eredményként nem felmutatható, mégis röviden szeretném megemlíteni a disszertáció 1. fejezetét. A fejezetben megadtam azokat az alapokat, amelyekkel 
eredményeim, illetve az azokhoz vezető út megérthető. Itt indokoltam meg a téma relevanciáját, és tekintettem át a téma szakirodalmát, valamint a terület fejlődését.

Az általam elvégzett elemzések, és a javasolt módszertan mind rámutatnak, hogy a hitelértékelési kiigazítás még számos kérdést hordoz magában, és a helyes válaszokhoz további kutató munkát kell elvégeznünk. Természetesen az általam bemutatott új eredmények sem limitáció mentesek, így azok továbbfejlesztése is kívánatos a téma alaposabb megértéséhez. Mindezek mellett érdemes tovább gondolni, hogy az ismertetett megoldások miként tudnák a CVA témakörét tovább bốvíteni.

A dolgozatban kevésbé foglalkoztam a rosszirányú kockázattal, amely a téma egy kiemelt fontosságú területének számít. Felmerül a kérdés, hogy az általam elvégzett elemzések hogyan járulhatnak hozzá a rosszirányú kockázat jobb leírásához, valamint méréséhez. Az egyik lehetséges megoldás a hitelminôsítôi bejelentések fertőzô hatásainak a kitettség profilokba történô beépítésével tehetô meg. Így a csôdvalószínúségeket és a kitettséget úgy kapcsolhatnánk össze, hogy azzal jó- vagy éppen rosszirányú kockázatot generáljunk. Ez azonban cseppet sem triviális kérdés, jelentôs további kutatást eredményezhet.

Hasonlóan kicsi szerepet kapott az XVA területe. Mint ahogy azt említettem, az XVA számítása számos párhuzamot hordoz a hitelértékelési kiigazítás meghatározásával. A már amúgy is jelentôs számítási kapacitás szükséglet az XVA-k megjelenésével tovább fokozódott. Így nyilvánvalóan adódik a kérdés, hogy az általam bevezetett hatékonyságjavítás bármilyen formában alkalmazható-e az XVA területén. Emellett természetesen a csődkorreláció és a tókeszámításban bemutatott kockázati mérték alkalmazása is jelentôs szerepet kaphat az XVA témájában is.

Eredményeim felhasználhatósága tekintetében valószínú további kutatási területek közé sorolom a hitelértékelési kiigazítás fedezésével és a CVA érzékenységeivel („Greeks”) foglalkozó kutatásokat. 


\section{Irodalomjegyzék}

Alfonsi, A. (2005). On the discretization schemes for the CIR (and Bessel squared) processes. Monte Carlo Methods and Applications, 11(4):355-384. doi:10.1515/156939605777438569.

Andersen, L. B., Pykhtin, M., és Sokol, A. (2017a). Does initial margin eliminate counterparty risk? Risk, 30(5):74-79.

Andersen, L. B., Pykhtin, M., és Sokol, A. (2017b). Rethinking the margin period of risk. Journal of Credit Risk, 13(1):1-45. doi:10.21314/JCR.2016.218.

Bao, Q., Chen, S., és Li, S. (2012). Unilateral CVA for CDS in a contagion model with stochastic pre-intensity and interest. Economic Modelling, 29(2):471-477. doi:10.1016/j.econmod.2011.12.002.

BCBS, (2011). Basel III: A global regulatory framework for more resilient banks and banking systems. Elérhető: https://www.bis.org/publ/bcbs189.htm.

BCBS, (2015). Review of the credit valuation adjustment risk framework. Elérhető: http://www.bis.org/bcbs/publ/d325.html.

BCBS, (2016a). Frequently asked questions on the CVA QIS exercise. Elérhető: https://www.bis.org/bcbs/qis/faq_CVA_QIS.pdf.

BCBS, (2016b). Minimum capital requirements for market risk. Elérhető: http://www.bis.org/bcbs/publ/d352.pdf.

BCBS, (2016c). Reducing variation in credit risk-weighted assets constraints on the use of internal model approaches. Elérhetô: http://www.bis.org/bcbs/publ/d362.htm.

BCBS, (2017). Basel III: Finalising post-crisis reforms. Elérhetô: https://www.bis.org/bcbs/publ/d424.pdf.

Béli, M. és Váradi, K. (2017). Alapletét meghatározásának lehetséges módszertana. Hitelintézeti Szemle, 16(2):117-145. 
Berns, C. (2016). Simultaneous hedging of regulatory and accounting CVA. In Glau K., Grbac Z., Scherer M., Zagst R. (szerk.) Innovations in derivatives markets, 165, 117-132. Springer. doi:10.1007/978-3-319-33446-2_6.

Biedermann, Z. és Orosz, Á. (2015). Eltérô irányú pénzügyi szabályozások a válság után? Hitelintézeti szemle, 14(1):30-56.

Bielecki, T. R., Cialenco, I., és Iyigunler, I. (2013). Collateralized CVA valuation with rating triggers and credit migrations. International Journal of Theoretical and Applied Finance, 16(02):1350009. doi:10.1142/S021902491350009X.

Bielecki, T. R. és Rutkowski, M. (2013). Credit risk: modeling, valuation and hedging. Springer-Verlag Berlin Heidelberg. doi:10.1007/978-3-662-04821-4.

Black, F. és Cox, J. C. (1976). Valuing corporate securities: Some effects of bond indenture provisions. The Journal of Finance, 31(2):351-367. doi:10.1111/j.1540-6261.1976.tb01891.x.

Black, F. és Scholes, M. (1973). The pricing of options and corporate liabilities. Journal of Political Economy, 81(3):637-654. doi:10.1086/260062.

Brigo, D. és Alfonsi, A. (2005). Credit default swap calibration and derivatives pricing with the SSRD stochastic intensity model. Finance and Stochastics, 9(1):29-42. doi:10.1007/s00780-004-0131-x.

Brigo, D., Buescu, C., és Morini, M. (2012). Counterparty risk pricing: Impact of closeout and first-to-default times. International Journal of Theoretical and Applied Finance, 15(06):1250039. doi:10.1142/S0219024912500392.

Brigo, D. és Capponi, A. (2008). Bilateral counterparty risk valuation with stochastic dynamical models and application to credit default swaps. Elérhető: arXiv 0812.3705

Brigo, D., Capponi, A., és Pallavicini, A. (2014). Arbitrage-free bilateral counterparty risk valuation under collateralization and application to credit default swaps. Mathematical Finance, 24(1):125-146. doi:10.1111/j.14679965.2012.00520.x.

Brigo, D., Capponi, A., Pallavicini, A., és Papatheodorou, V. (2011). Collateral margining in arbitrage-free counterparty valuation adjustment including rehypotecation and netting. Elérhetô: SSRN 1744101.

Brigo, D., Capponi, A., Pallavicini, A., és Papatheodorou, V. (2013a). Pricing counterparty risk including collateralization, netting rules, re-hypothecation 
and wrong-way risk. International Journal of Theoretical and Applied Finance, 16(02):1350007. doi:10.1142/S0219024913500076.

Brigo, D. és Chourdakis, K. (2009). Counterparty risk for credit default swaps: Impact of spread volatility and default correlation. International Journal of Theoretical and Applied Finance, 12(07):1007-1026. doi:10.1142/S0219024909005567.

Brigo, D. és Masetti, M. (2005). Risk neutral pricing of counterparty risk. In Pykhtin, M., szerk., Counterparty credit risk modelling: risk management, pricing, regulation. Risk Books, London.

Brigo, D. és Mercurio, F. (2007). Interest rate models-theory and practice: with smile, inflation and credit. Springer-Verlag Berlin Heidelberg. doi:10.1007/9783-540-34604-3.

Brigo, D. és Morini, M. (2006). Structural credit calibration. Risk, 19(4):78.

Brigo, D. és Morini, M. (2011). Close-out convention tensions. Risk, 24(12):74.

Brigo, D., Morini, M., és Pallavicini, A. (2013). Counterparty credit risk, collateral and funding: with pricing cases for all asset classes. John Wiley \& Sons. doi:10.1002/9781118818589.

Brigo, D. és Pallavicini, A. (2007). Counterparty risk pricing under correlation between default and interest rates. In Miller, J., Edelman, D., és Appleby, J. (Szerk): Numerical methods for finance, 79-98, Chapman and Hall/CRC. doi:10.1201/9781584889267.ch4.

Burgard, C. és Kajaer, M. (2010). PDE representation of options with bilateral counterparty risk and funding cost. Múhelytanulmány.

Burgard, C. és Kjaer, M. (2011). In the balance. Risk, 24(11):72-75.

Canabarro, E. és Duffie, D. (2004). Measuring and marking counterparty risk. In ALM of financial institutions, institutional investor books. Euromoney Institutional Investor.

Carriere, J. F. (1996). Valuation of the early-exercise price for options using simulations and nonparametric regression. Insurance: Mathematics and Economics, 19(1) :19-30. doi:10.1016/S0167-6687(96)00004-2.

Carver, L. (2011). The DVA debate. Risk, 24(11):71-71.

Carver, L. (2013). Capital or P\&L. Risk, 26(11):24-26. 
Castagna, A. (2012). The impossibility of DVA replication. Risk, 25(11):66-70.

Cesari, G., Aquilina, J., Charpillon, N., Filipovic, Z., Lee, G., és Manda, I. (2009). Modelling, pricing, and hedging counterparty credit exposure: A technical guide. Springer Science \& Business Media. doi:10.1007/978-3-642-04454-0.

Chan, R. H., Wong, C.-Y., és Yeung, K.-M. (2006). Pricing multi-asset Americanstyle options by memory reduction Monte Carlo methods. Applied Mathematics and Computation, 179(2):535-544. 10.1016/j.amc.2005.11.108.

Clément, E., Lamberton, D., és Protter, P. (2002). An analysis of a least squares regression method for American option pricing. Finance and Stochastics, 6(4):449-471. doi:10.1007/s007800200071.

Collin-Dufresne, P. és Solnik, B. (2001). On the term structure of default premia in the swap and LIBOR markets. The Journal of Finance, 56(3):1095-1115.

Cont, R. (2018). Margin requirements for non-cleared derivatives. ISDA.

Cox, J. C., Ingersoll Jr, J. E., és Ross, S. A. (1985). A theory of the term structure of interest rates. Econometrica, 53(2): 385-407. doi:10.2307/1911242.

Davis, M. és Lo, V. (2001). Infectious defaults. Quantitative Finance, 1(4):382387. doi:10.1080/713665832.

Delianedis, G. és Geske, R. (2001). The components of corporate credit spreads: Default, recovery, tax, jumps, liquidity, and market factors. Múhelytanulmány, Anderson Graduate School of Management, UCLA.

Duffie, D. és Huang, M. (1996). Swap rates and credit quality. Journal of Finance, 51(3):921-949. doi:10.1111/j.1540-6261.1996.tb02712.x.

Duffie, D. és Singleton, K. J. (1997). An econometric model of the term structure of interest-rate swap yields. The Journal of Finance, 52(4):1287-1321. doi:10.1111/j.1540-6261.1997.tb01111.x.

Duffie, D. és Singleton, K. J. (1999). Modeling term structures of defaultable bonds. The Review of Financial Studies, 12(4):687-720. doi:10.1093/rfs/12.4.687.

Duffie, D. és Zhu, H. (2011). Does a central clearing counterparty reduce counterparty risk? The Review of Asset Pricing Studies, 1(1):74-95. doi:10.1093/rapstu/rar001. 
Durand, C. és Rutkowski, M. (2013). CVA under alternative settlement conventions and with systemic risk. International Journal of Theoretical and Applied Finance, 16(07):1350039. doi:10.1142/S0219024913500398.

Feng, Q. és Oosterlee, C. W. (2017). Computing credit valuation adjustment for Bermudan options with wrong way risk. International Journal of Theoretical and Applied Finance, 20(08):1750056. doi:10.1142/S021902491750056X.

Finnerty, J. D., Miller, C. D., és Chen, R.-R. (2013). The impact of credit rating announcements on credit default swap spreads. Journal of Banking $\mathcal{E}$ Finance, 37(6) :2011-2030. doi:10.1016/j.jbankfin.2013.01.028.

Geske, R. (1977). The valuation of corporate liabilities as compound options. Journal of Financial and Quantitative Analysis, 12(4):541-552. doi: $10.2307 / 2330900$.

Geske, R. (1979). The valuation of compound options. Journal of Financial Economics, 7(1):63-81. doi:10.1016/0304-405X(79)90022-9.

Ghamami, S. és Goldberg, L. R. (2014). Stochastic intensity models of wrong way risk: Wrong way CVA need not exceed independent CVA. The Journal of Derivatives, 21(3):24-35. doi:10.3905/jod.2014.21.3.024.

Gibson, M. S. (2005). Measuring counterparty credit exposure to a margined counterparty. FEDs Working Paper No. 2005-50. Elérhető: SSRN 873867.

Giles, M. B. (2008). Multilevel Monte Carlo path simulation. Operations Research, 56(3):607-617. doi:10.1287/opre.1070.0496.

Giles, M. B. (2015). Multilevel Monte Carlo methods. Acta Numerica, 24:259328. doi:10.1017/S096249291500001X.

Glasserman, P. (2003). Monte Carlo methods in financial engineering, 53. Springer-Verlag New York. doi:10.1007/978-0-387-21617-1.

Glasserman, P. és Wu, Q. (2018). Persistence and procyclicality in margin requirements. Management Science, 64(12) 5704-5724. doi:10.1287/mnsc.2017.2915.

Glasserman, P. és Yang, L. (2016). Bounding wrong-way risk in CVA calculation. Mathematical Finance, 28(1):268-305. doi:10.1111/mafi.12141.

Gorton, G. és Metrick, A. (2012). Securitized banking and the run on repo. Journal of Financial Economics, 104(3):425-451. doi:10.3386/w15223.

Green, A. (2015). XVA: credit, funding and capital valuation adjustments. John Wiley \& Sons. doi:10.1002/9781119161233. 
Gregory, J. (2009). Being two-faced over counterparty credit risk. Risk, 22(2):8690.

Gregory, J. (2010). Counterparty credit risk: the new challenge for global financial markets. John Wiley \& Sons.

Gregory, J. (2014). Central counterparties: mandatory central clearing and initial margin requirements for OTC derivatives. John Wiley \& Sons.

Gregory, J. (2015). The XVA challenge: counterparty credit risk, funding, collateral and capital. John Wiley \& Sons.

Gregory, J. és German, I. (2013). Closing out DVA. Risk, 26(1):96-100.

Harvan, D. és Koncz, G. (2010). Hitelbedólések együttes modellezése: számít-e a korreláció. Hitelintézeti Szemle, 1:1-23.

Heinrich, S. (2001). Multilevel Monte Carlo methods. In Margenov S., Waśniewski J., Yalamov P. (szerk.) Large-scale scientific computing, 58-67. Springer. doi:10.1007/3-540-45346-6_5.

Hite, G. és Warga, A. (1997). The effect of bond-rating changes on bond price performance. Financial Analysts Journal, 53(3):35-51. doi:10.2469/faj.v53.n3.2083.

Hofer, M. és Karlsson, P. (2017). Efficient calibration for CVA using multi-level Monte Carlo. Elérhető: SSRN 2776932

Hu, W. és Zhou, J. (2017). Backward simulation methods for pricing American options under the CIR process. Quantitative Finance, 17(11):1-13. doi:10.1080/14697688.2017.1307513.

Hull, J. et al. (2010). OTC derivatives and central clearing: can all transactions be cleared? Financial Stability Review, 14:71-78.

Hull, J., Predescu, M., és White, A. (2004). The relationship between credit default swap spreads, bond yields, and credit rating announcements. Journal of Banking $\mathscr{E}$ Finance, 28(11):2789-2811. doi:10.1016/j.jbankfin.2004.06.010.

Hull, J. és White, A. (1995). The impact of default risk on the prices of options and other derivative securities. Journal of Banking \& Finance, 19(2):299-322. doi:10.1016/0378-4266(94)00050-D.

Hull, J. és White, A. (2012). CVA and wrong-way risk. Financial Analysts Journal, 68(5):58-69. doi:10.2307/41713536. 
Hull, J. C. és White, A. (2000). Valuing credit default swaps ii: modeling default correlations. The Journal of Derivatives, 8(3):12-21. doi:10.3905/jod.2001.319153.

Jain, S. és Oosterlee, C. W. (2015). The stochastic grid bundling method: Efficient pricing of Bermudan options and their Greeks. Applied Mathematics and Computation, 269:412-431. doi:10.1016/j.amc.2015.07.085.

Jarrow, R. A., Lando, D., és Turnbull, S. M. (1997). A Markov model for the term structure of credit risk spreads. The Review of Financial Studies, 10(2):481523. 10.1142/9789812819222_0018.

Jarrow, R. A. és Turnbull, S. M. (1995). Pricing derivatives on financial securities subject to credit risk. The Journal of Finance, 50(1):53-85. doi $: 10.2307 / 2329239$.

Jarrow, R. A. és Yu, F. (2001). Counterparty risk and the pricing of defaultable securities. The Journal of Finance, 56(5):1765-1799. doi:10.1111/00221082.00389 .

Jorion, P. és Zhang, G. (2009). Credit contagion from counterparty risk. The Journal of Finance, 64(5):2053-2087.

Joshi, M. és Kwon, O. K. (2016). Least squares Monte Carlo credit value adjustment with small and unidirectional bias. International Journal of Theoretical and Applied Finance, 19(08):1650048. doi:10.1142/S0219024916500485.

Kan, K. H. és Reesor, R. M. (2012). Bias reduction for pricing American options by least-squares Monte Carlo. Applied Mathematical Finance, 19(3):195-217. doi:10.1080/1350486X.2011.608566.

Kan, K. H. F., Frank, G., Mozgin, V., és Reesor, M. (2010). Optimized leastsquares Monte Carlo for measuring counterparty credit exposure of Americanstyle options. Mathematics-in-Industry Case Studies Journal, 2:64-85.

Karlsson, P., Jain, S., és Oosterlee, C. W. (2016). Counterparty credit exposures for interest rate derivatives using the stochastic grid bundling method. Applied Mathematical Finance, 23(3):175-196. doi:10.1080/1350486X.2016.1226144.

Kim, I. J., Ramaswamy, K., Sundaresan, S., et al. (1988). The valuation of corporate fixed income securities. Salomon Bros. Center for the Study of Financial Institutions, Graduate School of Business Administration, New York University. 
Ladoniczki, S. K. és Váradi, K. (2018). Elszámolóházak alapbiztosítéki követelményeinek számítási módszertana. Közgazdasági Szemle, 65(7/8):780-856.

Lando, D. (1998). On Cox processes and credit risky securities. Review of Derivatives Research, 2(2-3):99-120. doi:10.1007/BF01531332.

Lando, D. (2000). Some elements of rating-based credit risk modeling. In Advanced fixed-income valuation tools, 193-215, IEEE Computer Society Press.

Lando, D. (2009). Credit risk modeling: theory and applications. Princeton University Press.

Leung, K. S. és Kwok, Y. K. (2009). Counterparty risk for credit default swaps: Markov chain interacting intensities model with stochastic intensity. AsiaPacific Financial Markets, 16(3):169-181. doi:10.1007/s10690-009-9091-7.

Leung, S. Y. és Kwok, Y. K. (2005). Credit default swap valuation with counterparty risk. The Kyoto Economic Review, 74(1):25-45. doi:10.11179/ker.74.25.

Longstaff, F. A. és Schwartz, E. S. (1995). A simple approach to valuing risky fixed and floating rate debt. The Journal of Finance, 50(3):789-819. 10.1111/j.15406261.1995.tb04037.x.

Longstaff, F. A. és Schwartz, E. S. (2001). Valuing American options by simulation: a simple least-squares approach. The Review of Financial Studies, $14(1): 113-147$.

Memartoluie, A., Saunders, D., és Wirjanto, T. (2017). Wrong-way risk bounds in counterparty credit risk management. Journal of Risk Management in Financial Institutions, 10(2):150-163.

Merton, R. C. (1973). Theory of rational option pricing. The Bell Journal of Economics and Management Science, 4(1):141-183. doi:10.2307/3003143.

Merton, R. C. (1974). On the pricing of corporate debt: The risk structure of interest rates. The Journal of Finance, 29(2):449-470. doi:10.2307/2978814.

Micu, M., Remolona, E., Wooldridge, P., et al. (2006). The price impact of rating announcements: evidence from the credit default swap market. BIS Quarterly Review, 2(June) :55-65.

Murphy, D., Vasios, M., és Vause, N. (2016). A comparative analysis of tools to limit the procyclicality of initial margin requirements. Bank of England Working Paper No. 597. Elérhető: SSRN 2772569. 
Nielsen, L., Saa-Requejo, J., Santa-Clara, P. (1993). Default risk and interest rate risk. Múhelytanulmány, INSEAD, 93.

Norden, L. és Weber, M. (2004). Informational efficiency of credit default swap and stock markets: The impact of credit rating announcements. Journal of Banking \& Finance, 28(11):2813-2843. doi:10.1016/j.jbankfin.2004.06.011.

O'Kane, D. (2011). Modelling single-name and multi-name credit derivatives, John Wiley \& Sons.

Pálosi-Németh, B. (2012). Partnerkockázat-a pénzügyi piacok átalakulásának origója. Hitelintézeti Szemle, 11(6):479-504.

Pálosi-Németh, B. (2015). Partnerkockázat-tovább a szabályozói úton. Gazdaság és Pénzügy, 2(1):63-78.

Pang, T., Chen, W., és Li, L. (2015). CVA wrong way risk multiplier decomposition and efficient CVA curve. Journal of Risk Management in Financial Institutions, 8(4):390-404.

Pye, G. (1974). Gauging the default premium. Financial Analysts Journal, $30(1): 49-52$.

Pykhtin, M. (2009a). Modeling credit exposure for collateralized counterparties. Fields Institute Quantitative Finance Seminar.

Pykhtin, M. (2009b). Modeling credit exposure for collateralized counterparties. The Journal of Credit risk, 5(4):3-27. doi:10.21314/JCR.2009.100.

Pykhtin, M. (2012). Model foundations of the Basel III standardised CVA charge. Risk, 25(7):60-67.

Pykhtin, M. és Rosen, D. (2010). Pricing counterparty risk at the trade level and credit valuation adjustment allocations. The Journal of Credit Risk, 6(4):3-38. doi:10.21314/JCR.2010.116.

Pykhtin, M. és Zhu, S. H. (2006). Measuring counterparty credit risk for trading products under Basel II. In Ong, M., szerk, Basel handbook. Risk Books, London, 2 kiadás.

Rosen, D. és Saunders, D. (2012). CVA the wrong way. Journal of Risk Management in Financial Institutions, 5(3):252-272.

Savickas, V., Hari, N., Wood, T., és Kandhai, D. (2014). Super fast greeks: An application to counterparty valuation adjustments. Wilmott, 2014(69):76-81. doi:10.1002/wilm.10291. 
Schönbucher, P. J. (1996). The term structure of defaultable bond prices. Múhelytanulmány

Schönbucher, P. J. (2003). Credit Derivatives Pricing Models: Models, Pricing and Implementation. John Wiley \& Sons.

Schönbucher, P. J. és Schubert, D. (2001). Copula-dependent default risk in intensity models. Múhelytanulmány.

Sherif, N. (2016). Basel considered axing standardised approach to CVA calculation. Elérhető: http://www.risk.net/risk-management/2477114/baselconsidered-axing-standardised-approach-cva-calculation.

Skoglund, J., Vestal, D., és Chen, W. (2013). Credit valuation adjustment tail risk and the impact of wrong way trades. Journal of Risk Management in Financial Institutions, 6(3):280-301.

Sokol, A. (2010). A practical guide to Monte Carlo CVA. In Berd, A. (szerk) Lessons from the financial crisis, 379-406 Risk Books London.

Sorensen, E. H. és Bollier, T. F. (1994). Pricing swap default risk. Financial Analysts Journal, 50(3):23-33.

Steiner, M. és Heinke, V. G. (2001). Event study concerning international bond price effects of credit rating actions. International Journal of Finance \& Economics, 6(2):139-157. doi:10.1002/ijfe.148.

Trueck, S. és Rachev, S. T. (2009). Rating based modeling of credit Risk: theory and application of migration matrices. Academic Press. doi:10.1016/B978-012-373683-3.X0001-2.

Tsitsiklis, J. N. és Van Roy, B. (2001). Regression methods for pricing complex American-style options. IEEE Transactions on Neural Networks, 12(4):694703. doi:10.1109/72.935083.

Vasicek, O. (1977). An equilibrium characterization of the term structure. Journal of Financial Economics, 5(2):177-188. doi:10.1016/0304-405X(77)90016-2.

Vrins, F. (2017). Wrong-way risk CVA models with analytical EPE profiles under Gaussian exposure dynamics. International Journal of Theoretical and Applied Finance, 20(07):1750045. doi:10.1142/S0219024917500455.

Vrins, F. és Gregory, J. (2011). Getting CVA up and running. Risk, 24(11):76-79.

Walker, M. B. (2006). Credit default swaps with counterparty risk: A calibrated Markov model. Journal of Credit Risk, 2(1):31-49. doi:10.21314/JCR.2006.031. 
Weeber, P. (2009). Market practices for settling derivatives in bankruptcy: Part I. American Bankruptcy Institute Journal, 28(8):26-29.

Weeber, P. és Robson, E. S. (2009). Market practices for settling derivatives in bankruptcy: Part II. American Bankruptcy Institute Journal, 28(9):34-37.

Weinstein, M. I. (1977). The effect of a rating change announcement on bond price. Journal of Financial Economics, 5(3):329-350. doi:10.1016/0304405X(77)90042-3.

Wengner, A., Burghof, H.-P., és Schneider, J. (2015). The impact of credit rating announcements on corporate CDS markets - are intraindustry effects observable? Journal of Economics and Business, 78:79-91. doi:10.1016/j.jeconbus.2014.11.003.

Wood, D. (2016). Crying wolf on CVA? Elérhető: http://www.risk.net/regulation/basel-committee/2452746/crying-wolf-cva.

Yi, C. (2011). Dangerous knowledge: Credit value adjustment with credit triggers. International Journal of Theoretical and Applied Finance, 14(06):839865. doi:10.1142/S0219024911006395.

Yu, F. (2007). Correlated defaults in intensity-based models. Mathematical Finance, 17(2):155-173. doi:10.1111/j.1467-9965.2007.00298.x.

Zheng, H. (2013). Contagion models a la carte: which one to choose? Quantitative Finance, 13(3):399-405. doi:10.1080/14697688.2012.708428.

Zhou, C. (1997). A jump-diffusion approach to modeling credit risk and valuing defaultable securities. Múhelytanulmány

Zhu, S. H. és Pykhtin, M. (2007). A guide to modeling counterparty credit risk. GARP Risk Review, July/August. Elérhetô: SSRN 1032522. 


\section{Saját publikációk}

\section{Folyóirat cikkek:}

- Boros, P. (2016). Hitelértékelési kiigazítás - a fedezeti haircut modellbe illesztése. Szigma, 47(1-2):31-45.

- Boros, P. (2018a). A hitelértékelési kiigazítás tôketartalékolásának új szabályozása. Közgazdasági Szemle, 65(2):161-184.

- Boros, P. (2018b). A kitettség profilok becslése többszintú Monte Carlo módszerrel. Szigma, 49(1-2):39-56.

- Boros, P. és Medvegyev, P. (2017). Közvélemény-kutatások statisztikai szemszögból - ahol biztosan hibáztak. Közgazdasági Szemle, 64:1265-1284.

\section{Konferencia előadások :}

- Boros, P. (2015). Credit Valuation Adjustment - A fedezeti haircut modellbe illesztése. Közgazdaságtani Doktori Iskola XI. éves konferenciája 2015.11.12.

- Boros, P. (2017). Rating migration, credit risk contagion and Credit Valuation Adjustment. Közgazdaságtani Doktori Iskola XIII. éves konferenciája 2017.11.09.

- Boros, P. (2017). Credit Exposure Estimation with least-square Monte Carlo. Tavaszi Szél Konferencia 2017.03.31.

Konferencia Kiadvány: Tavaszi Szél Konferencia 2017, Nemzetközi Multidiszciplenáris Konferencia Absztraktkötet (2017) DOSZ, ISBN 978-615$5586-14-9$

- Boros, P. (2017). A hitelértékelési kiigazítás tőketartalékolásának új szabályozása. PRMIA Hungary Chapter Éves Konferenciája, 2017 2017.11.23.

Konferencia Kiadvány: PRMIA Hungary Chapter Éves Konferenciája, 2017, A Magyar kockázatkezelési kutatások legújabb eredményei Konferencia Kötet (2017) PRMIA, ISBN 978-615-80642-5-5

\section{Könyvismertetés :}

- Boros, P. (2015). Lépés a partnerkockázat megfelelő árazása felé: Damiano Brigo-Massimo Morini-Andrea Pallavicini: Counterparty Credit Risk, Collateral and Funding: With Pricing Cases For All Asset Classes John Wiley and Sons, Chichester, West Sussex, 2013, 464 o. Közgazdasági Szemle, $62: 457-461$. 